Cochrane Database of Systematic Reviews

\title{
Probiotics for the prevention of pediatric antibiotic-associated diarrhea (Review)
}

Guo Q, Goldenberg JZ, Humphrey C, El Dib R, Johnston BC

Guo Q, Goldenberg JZ, Humphrey C, El Dib R, Johnston BC.

Probiotics for the prevention of pediatric antibiotic-associated diarrhea.

Cochrane Database of Systematic Reviews 2019, Issue 4. Art. No.: CD004827.

DOI: 10.1002/14651858.CD004827.pub5.

www.cochranelibrary.com 
TABLE OF CONTENTS

HEADER

ABSTRACT

PLAIN LANGUAGE SUMMARY

SUMMARY OF FINDINGS

BACKGROUND

OBJECTIVES

METHODS

RESULTS

Figure 1.

Figure 2.

Figure 3.

Figure 4.

Figure 5.

DISCUSSION

Figure 6.

AUTHORS' CONCLUSIONS

ACKNOWLEDGEMENTS

REFERENCES

CHARACTERISTICS OF STUDIES

DATA AND ANALYSES

Analysis 1.1. Comparison 1 Probiotics versus control, Outcome 1 Incidence of diarrhea: Complete case.

Analysis 1.2. Comparison 1 Probiotics versus control, Outcome 2 Incidence of diarrhea: Inpatient versus outpatient. .............

Analysis 1.3. Comparison 1 Probiotics versus control, Outcome 3 Incidence of diarrhea: Diagnosis. .......................................

Analysis 1.4. Comparison 1 Probiotics versus control, Outcome 4 Incidence of diarrhea: Probiotic species.

Analysis 1.5. Comparison 1 Probiotics versus control, Outcome 5 Incidence of diarrhea: Single strain versus multi strain. ........

Analysis 1.6. Comparison 1 Probiotics versus control, Outcome 6 Incidence of diarrhea: Probiotic dose.

Analysis 1.7. Comparison 1 Probiotics versus control, Outcome 7 Incidence of diarrhea: Definition of diarrhea.

Analysis 1.8. Comparison 1 Probiotics versus control, Outcome 8 Incidence of diarrhea: Strictness of definition (mild vs moderate).

Analysis 1.9. Comparison 1 Probiotics versus control, Outcome 9 Incidence of diarrhea: Industry sponsorship.

Analysis 1.10. Comparison 1 Probiotics versus control, Outcome 10 Incidence of diarrhea: Risk of bias.

Analysis 1.11. Comparison 1 Probiotics versus control, Outcome 11 Incidence of diarrhea: age.

Analysis 1.12. Comparison 1 Probiotics versus control, Outcome 12 Incidence of diarrhea: Sensitivity analysis (complete case - fixed effects).

Analysis 1.13. Comparison 1 Probiotics versus control, Outcome 13 Incidence of diarrhea: Probiotic dose (extreme-plausible analysis).

Analysis 1.14. Comparison 1 Probiotics versus control, Outcome 14 Incidence of diarrhea: Sensitivity analysis (missing outcome data - extreme plausible analysis).

Analysis 1.15. Comparison 1 Probiotics versus control, Outcome 15 Adverse events: Complete case.

Analysis 1.16. Comparison 1 Probiotics versus control, Outcome 16 Adverse events: Same event rate assumptions analysis. ...

Analysis 1.17. Comparison 1 Probiotics versus control, Outcome 17 Adverse events: Risk of bias.

Analysis 1.18. Comparison 1 Probiotics versus control, Outcome 18 Mean duration of diarrhea: Complete case.

APPENDICES

WHAT'S NEW

HISTORY

CONTRIBUTIONS OF AUTHORS

DECLARATIONS OF INTEREST

SOURCES OF SUPPORT

DIFFERENCES BETWEEN PROTOCOL AND REVIEW

NOTES

INDEX TERMS

1

1

2

4

7

8

8

10

10

13

14

19

20

20

21

24

24

25

32

69

73

74

75

76

80

81

82

84

85

86

87

88

89

90

92

92

93

94

95

100

100

100

101

101

101

101

101

Probiotics for the prevention of pediatric antibiotic-associated diarrhea (Review)

Copyright $\odot 2019$ The Cochrane Collaboration. Published by John Wiley \& Sons, Ltd. 
[Intervention Review]

\section{Probiotics for the prevention of pediatric antibiotic-associated diarrhea}

Qin Guo ${ }^{1}$, Joshua Z Goldenberg 2 , Claire Humphrey ${ }^{3}$, Regina El Dib ${ }^{4}$, Bradley C Johnston 5

1Department of Pediatrics, West China Second University Hospital, West China Women's and Children's Hospital, Chengdu, China. ${ }^{2}$ Helfgott Research Institute, National University of Natural Medicine, Portland, OR, USA. ${ }^{3}$ Department of Pediatrics, Dalhousie University, Halifax, Canada. ${ }^{4}$ Department of Biosciences and Oral Diagnosis, Institute of Science and Technology, UNESP - Univ Estadual Paulista, São José dos Campos, Brazil. 5Department of Community Health and Epidemiology, Dalhousie University, Halifax, Canada

Contact address: Bradley C Johnston, Department of Community Health and Epidemiology, Dalhousie University, 5790 University Avenue, Halifax, NS, B3H 1V7, Canada. bjohnston@dal.ca.

Editorial group: Cochrane IBD Group.

Publication status and date: Edited (no change to conclusions), published in Issue 5, 2019.

Citation: Guo Q, Goldenberg JZ, Humphrey C, El Dib R, Johnston BC. Probiotics for the prevention of pediatric antibiotic-associated diarrhea. Cochrane Database of Systematic Reviews 2019, Issue 4. Art. No.: CD004827. DOI: 10.1002/14651858.CD004827.pub5.

Copyright ( 2019 The Cochrane Collaboration. Published by John Wiley \& Sons, Ltd.

\section{A B S T R A C T}

\section{Background}

Antibiotics alter the microbial balance commonly resulting in antibiotic-associated diarrhea (AAD). Probiotics may prevent AAD via providing gut barrier, restoration of the gut microflora, and other potential mechanisms of action.

\section{Objectives}

The primary objectives were to assess the efficacy and safety of probiotics (any specified strain or dose) used for the prevention of AAD in children.

\section{Search methods}

MEDLINE, Embase, CENTRAL, CINAHL, and the Web of Science (inception to 28 May 2018) were searched along with registers including the ISRCTN and Clinicaltrials.gov. We also searched the NICE Evidence Services database as well as reference lists from relevant articles.

\section{Selection criteria}

Randomized, parallel, controlled trials in children (0 to 18 years) receiving antibiotics, that compare probiotics to placebo, active alternative prophylaxis, or no treatment and measure the incidence of diarrhea secondary to antibiotic use were considered for inclusion.

\section{Data collection and analysis}

Study selection, data extraction, and risk of bias assessment were conducted independently by two authors. Dichotomous data (incidence of $A A D$, adverse events) were combined using a pooled risk ratio (RR) or risk difference (RD), and continuous data (mean duration of diarrhea) as mean difference (MD), along with corresponding $95 \%$ confidence interval $(95 \% \mathrm{Cl})$. We calculated the number needed to treat for an additional beneficial outcome (NNTB) where appropriate. For studies reporting on microbiome characteristics using heterogeneous outcomes, we describe the results narratively. The certainty of the evidence was evaluated using GRADE.

\section{Main results}

Thirty-three studies (6352 participants) were included. Probiotics assessed included Bacillus spp., Bifidobacterium spp., Clostridium butyricum, Lactobacilli spp., Lactococcus spp., Leuconostoc cremoris, Saccharomyces spp., orStreptococcus spp., alone or in combination. The risk of bias was determined to be high in 20 studies and low in 13 studies. Complete case (patients who did not complete the studies were not included in the analysis) results from 33 trials reporting on the incidence of diarrhea show a precise benefit from probiotics compared to active, placebo or no treatment control. 
After 5 days to 12 weeks of follow-up, the incidence of AAD in the probiotic group was $8 \%$ (259/3232) compared to $19 \%$ (598/3120) in the control group (RR $0.45,95 \% \mathrm{Cl} 0.36$ to $0.56 ; \mathrm{I}^{2}=57 \%, 6352$ participants; NNTB 9, 95\% Cl 7 to 13; moderate certainty evidence). Nineteen studies had loss to follow-up ranging from $1 \%$ to $46 \%$. After making assumptions for those lost, the observed benefit was still statistically significant using an extreme plausible intention-to-treat (ITT) analysis, wherein the incidence of AAD in the probiotic group was $12 \%$ (436/3551) compared to $19 \%(664 / 3468)$ in the control group (7019 participants; RR $0.61 ; 95 \% \mathrm{Cl} 0.49$ to $\left.0.77 ; \mathrm{P}<0.00001 ; \mathrm{I}^{2}=70 \%\right)$. An a priori available case subgroup analysis exploring heterogeneity indicated that high dose ( $\geq 5$ billion CFUs per day) is more effective than low probiotic dose ( $<5$ billion CFUs per day), interaction $\mathrm{P}$ value $=0.01$. For the high dose studies the incidence of AAD in the probiotic group was $8 \%(162 / 2029)$ compared to $23 \%(462 / 2009)$ in the control group ( 4038 participants; RR $0.37 ; 95 \% \mathrm{Cl} 0.30$ to $0.46 ; \mathrm{P}=0.06 ;$ moderate certainty evidence). For the low dose studies the incidence of AAD in the probiotic group was $8 \%(97 / 1155)$ compared to $13 \%$ (133/1059) in the control group (2214 participants; RR $0.68 ; 95 \% \mathrm{Cl} 0.46$ to $1.01 ; \mathrm{P}=0.02$ ). Again, assumptions for loss to follow-up using an extreme plausible ITT analysis was statistically significant. For high dose studies the incidence of AAD in the probiotic group was $13 \%(278 / 2218)$ compared to $23 \%$ (503/2207) in control group (4425 participants; RR 0.54; $95 \% \mathrm{Cl} 0.42$ to $0.70 ; \mathrm{P}<0.00001 ; \mathrm{I}^{2}=68 \%$; moderate certainty evidence).

None of the 24 trials (4415 participants) that reported on adverse events reported any serious adverse events attributable to probiotics. Adverse event rates were low. After 5 days to 4 weeks follow-up, $4 \%(86 / 2229)$ of probiotics participants had an adverse event compared to $6 \%(121 / 2186)$ of control participants (RD $0.00 ; 95 \% \mathrm{Cl}-0.01$ to $0.01 ; \mathrm{P}<0.00001 ; \mathrm{I}^{2}=75 \%$; low certainty evidence). Common adverse events included rash, nausea, gas, flatulence, abdominal bloating, and constipation.

After 10 days to 12 weeks of follow-up, eight studies recorded data on our secondary outcome, the mean duration of diarrhea; with probiotics reducing diarrhea duration by almost one day (MD $-0.91 ; 95 \% \mathrm{Cl}-1.38$ to $-0.44 ; \mathrm{P}<0.00001$; low certainty evidence). One study reported on microbiome characteristics, reporting no difference in changes with concurrent antibiotic and probiotic use.

\section{Authors' conclusions}

The overall evidence suggests a moderate protective effect of probiotics for preventing AAD (NNTB 9, 95\% $\mathrm{Cl} 7$ to 13 ). Using five criteria to evaluate the credibility of the subgroup analysis on probiotic dose, the results indicate the subgroup effect based on high dose probiotics ( $\geq 5$ billion CFUs per day) was credible. Based on high-dose probiotics, the NNTB to prevent one case of diarrhea is 6 ( $95 \%$ CI 5 to 9 ). The overall certainty of the evidence for the primary endpoint, incidence of AAD, based on high dose probiotics was moderate due to the minor issues with risk of bias and inconsistency related to a diversity of probiotic agents used. Evidence also suggests that probiotics may moderately reduce the duration of diarrhea, a reduction by almost one day. The benefit of high dose probiotics (e.g. Lactobacillus rhamnosus orSaccharomyces boulardii) needs to be confirmed by a large well-designed multi-centered randomized trial. It is premature to draw firm conclusions about the efficacy and safety of 'other' probiotic agents as an adjunct to antibiotics in children. Adverse event rates were low and no serious adverse events were attributable to probiotics. Although no serious adverse events were observed among inpatient and outpatient children, including small studies conducted in the intensive care unit and in the neonatal unit, observational studies not included in this review have reported serious adverse events in severely debilitated or immuno-compromised children with underlying risk factors including central venous catheter use and disorders associated with bacterial/fungal translocation.

\section{PLAIN LANGUAGE SUMMARY}

\section{Probiotics for the prevention of antibiotic-associated diarrhea in children}

\section{What is antibiotic-associated diarrhea?}

Antibiotic-associated diarrhea (AAD) occurs when antibiotics disturb the natural balance of "good" and "bad" bacteria in the intestinal tract causing harmful bacteria to multiply beyond their normal numbers. The symptoms of AAD include frequent watery bowel movements and crampy abdominal pain.

\section{What are probiotics?}

Probiotics are found in dietary supplements or yogurts and contain potentially beneficial bacteria or yeast. Probiotics may restore the natural balance of bacteria in the intestinal tract.

\section{What did the researchers investigate?}

The researchers investigated whether probiotics prevent AAD in children receiving antibiotic therapy and whether probiotics causes any harms (side effects). The researchers searched the medical literature extensively up to May 28, 2018.

\section{What did the researchers find?}

Thirty-three studies were reviewed and provide the best available evidence. The studies tested 6352 children (3 days to 17 years of age) who were receiving probiotics co-administered with antibiotics to prevent AAD. The participants received probiotics (Lactobacilli spp., Bifidobacterium spp., Streptococcus spp., or Saccharomyces boulardii alone or in combination), placebo (pills not including probiotics), other treatments thought to prevent AAD (i.e. diosmectite or infant formula) or no treatment. The studies were short-term, ranging in length from 5 days to 12 weeks. Analyses showed that probiotics are effective for preventing AAD. The incidence of AAD in the probiotic 
group was $8 \%$ (259/3232) compared to $19 \%$ (598/3120) in the control group, demonstrating a moderate reduction (11\% fewer will suffer diarrhea). For every 9 children treated, probiotics will prevent one case of diarrhea. Further, evidence suggests that higher dose probiotics ( $\geq 5$ billion CFUs per day) reduce the incidence of AAD. Eight per cent (162/2029) of the high dose probiotics group had AAD compared to $23 \%$ $(462 / 2009)$ in the control group, demonstrating a moderate to large reduction (15\% fewer suffer diarrhea). Probiotics were generally well tolerated, and minor side effects (e.g. rash, nausea, gas, flatulence, abdominal bloating, constipation) occurred infrequently. . Evidence suggested that probiotics are effective for a moderate reduction in duration of diarrhea (almost one day). Among the various probiotics evaluated, Lactobacillus rhamnosus or Saccharomyces boulardii at 5 to 40 billion colony forming units/day appear most appropriate for preventing AAD in children receiving antibiotics. It is premature to draw conclusions about the effectiveness and safety of 'other' probiotic agents for preventing AAD. Although no serious probiotic-related side effects were observed among the mostly otherwise healthy children who participated in the studies, serious side effects have been reported in observational studies not included in this review, including severely debilitated or immuno-compromised children with underlying risk factors including central venous catheter (a flexible tube used to give medicines) use and disorders associated with bacterial or fungal translocation (the passage of bacteria from the gut to other areas of the body). 
SUMMARY OF FINDINGS

Summary of findings for the main comparison. Probiotics as an adjunct to antibiotics for the prevention of antibiotic-associated diarrhea in children

Probiotics as an adjunct to antibiotics for the prevention of antibiotic-associated diarrhea in children

Patient or population: Children receiving antibiotic treatment between 4 and 28 days duration for a variety of infections

Settings: Inpatient and outpatient

Intervention: Probiotics treatment with either Bacillus spp., Bifidobacterium spp., Clostridium butyricum spp., Lactobacilli spp., Lactococcus spp., Leuconostoc cremoris spp., Saccharomyces spp., or Streptococcus spp., alone or in combination

Comparison: Control (placebo or non-active control)

\begin{tabular}{|c|c|c|c|c|c|c|c|}
\hline \multirow[t]{3}{*}{ Outcomes } & \multicolumn{3}{|c|}{ Anticipated absolute effects * $(95 \% \mathrm{Cl})$} & \multirow{3}{*}{$\begin{array}{l}\text { Relative ef- } \\
\text { fect } \\
(95 \% \mathrm{CI})\end{array}$} & \multirow{3}{*}{$\begin{array}{l}\text { No of Partici- } \\
\text { pants } \\
\text { (studies) }\end{array}$} & \multirow{3}{*}{$\begin{array}{l}\text { Quality of the } \\
\text { evidence } \\
\text { (GRADE) }\end{array}$} & \multirow[t]{3}{*}{ Comments } \\
\hline & Baseline risk & $\begin{array}{l}\text { Corresponding } \\
\text { risk }\end{array}$ & & & & & \\
\hline & $\begin{array}{l}\text { Risk in Con- } \\
\text { trol }\end{array}$ & $\begin{array}{l}\text { Risk with Pro- } \\
\text { biotics }\end{array}$ & Risk Difference & & & & \\
\hline $\begin{array}{l}\text { Incidence of AAD } \\
\text { Follow-up: } 5 \text { days to } 12 \text { weeks }\end{array}$ & 190 per $1000^{1}$ & $\begin{array}{l}86 \text { per } 1000 \\
(68 \text { to } 106)\end{array}$ & $\begin{array}{l}104 \text { fewer AAD } \\
\text { cases per } 1000 \\
\text { (84 fewer to } 122 \\
\text { fewer) }\end{array}$ & $\begin{array}{l}\mathbf{R R} \mathbf{0 . 4 5}(0.36 \\
\text { to } 0.56)\end{array}$ & $\begin{array}{l}6352 \\
\text { (33 studies) }\end{array}$ & $\begin{array}{l}\oplus \oplus \oplus \ominus \\
\text { Moder- } \\
\text { ate }^{2.3 .4}\end{array}$ & \\
\hline $\begin{array}{l}\text { Incidence of AAD: Probiotic } \\
\text { dose ( } \geq 5 \text { billion CFUs of probi- } \\
\text { otics/day) } \\
\text { Follow-up: } 5 \text { days to } 12 \text { weeks }\end{array}$ & 190 per $1000^{1}$ & $\begin{array}{l}70 \text { per } 1000 \\
\text { (57 to } 87 \text { ) }\end{array}$ & $\begin{array}{l}\mathbf{1 2 0} \text { fewer AAD } \\
\text { cases per } \mathbf{1 0 0 0} \\
\text { (103 fewer to } 133 \\
\text { fewer) }\end{array}$ & $\begin{array}{l}\mathbf{R R} 0.37(0.30 \\
\text { to } 0.46)\end{array}$ & $\begin{array}{l}4038 \\
\text { (20 studies) }\end{array}$ & $\begin{array}{l}\oplus \oplus \oplus \ominus \\
\text { Moderate }^{5.6}\end{array}$ & $\begin{array}{l}\text { Based on our a priori } \\
\text { subgroup analyses, } \\
\text { high-dose probiotics ( } \geq 5 \\
\text { billion CFUs/day) are } \\
\text { most effective }\end{array}$ \\
\hline $\begin{array}{l}\text { Adverse events } \\
\text { Follow-up: } 5 \text { days to } 4 \text { weeks }\end{array}$ & 55 per $1000^{7}$ & $\begin{array}{l}39 \text { per } 1000 \\
(25 \text { to } 61)\end{array}$ & $\begin{array}{l}16 \text { fewer ad- } \\
\text { verse events per } \\
1000\end{array}$ & $\begin{array}{l}\text { RD }-\mathbf{0 . 0 0} \\
(-0.01 \text { to } 0.01)\end{array}$ & $\begin{array}{l}4415 \\
\text { (24 studies) }\end{array}$ & $\begin{array}{l}\oplus \oplus \ominus \ominus \\
\text { Low }^{8.9 .10 .11}\end{array}$ & \\
\hline
\end{tabular}




\begin{tabular}{|c|c|c|c|c|}
\hline & & $\begin{array}{l}\text { (6 more to } 30 \\
\text { fewer) }\end{array}$ & & \\
\hline $\begin{array}{l}\text { Duration of diarrhea (days) } \\
\text { Follow-up: } 10 \text { days to } 12 \text { weeks }\end{array}$ & $\begin{array}{l}\text { MD } 0.91 \text { fewer } \\
\text { (1.38 fewer to } \\
0.44 \text { fewer) }\end{array}$ & & $\begin{array}{l}1263 \\
\text { (8 studies) }\end{array}$ & $\begin{array}{l}\oplus \oplus \odot \ominus \\
\text { Low } 12.13\end{array}$ \\
\hline $\begin{array}{l}\text { Microbiome characteristics } \\
\text { Follow-up: one day to one month } \\
\text { after cessation of antibiotic ther- } \\
\text { apy }\end{array}$ & & & $\begin{array}{l}40 \\
\text { (1 study) }\end{array}$ & $\begin{array}{l}\oplus \odot \Theta \odot \\
\text { Very low } 14.15\end{array}$ \\
\hline
\end{tabular}

*The basis for the baseline risk (e.g. the median control group risk across studies) is provided in footnotes. The corresponding risk (and its $95 \%$ confidence interval) is based on the assumed risk in the comparison group and the relative effect of the intervention (and its $95 \% \mathrm{Cl}$ ).

Cl: Confidence interval; MD: Mean difference; RD: Risk difference; RR: Risk Ratio

AAD: antibiotic-associated diarrhea;

GRADE Working Group grades of evidence

High quality: Further research is very unlikely to change our confidence in the estimate of effect.

Moderate quality: Further research is likely to have an important impact on our confidence in the estimate of effect and may change the estimate.

Low quality: Further research is very likely to have an important impact on our confidence in the estimate of effect and is likely to change the estimate.

Very low quality: We are very uncertain about the estimate.

1 Baseline/control group risk estimates come from pooled estimates of control group among 33 included studies.

220 of 33 studies were rated as high risk of bias to due to issues with lack of blinding, or lack of concealment of allocation, or loss to follow-up (LTFU) or industry sponsorship. Loss to follow-up was substantial (>20\%) in 6 studies. In particular, LTFU was 46.4\% (King 2010) and 36.6\% in two small studies (Tankanow 1990), respectively; and 29\% in two additional studies (Arvola 1999; Erdeve 2004), one of which was the largest eligible trial included in our review ( $n=653$ ) (Erdeve 2004). However, a test for interaction between low risk of bias trials and high or unclear risk of bias trials was not statistically significant $(P=0.30)$. Further, we conducted a sensitivity analysis wherein we made assumptions about the outcomes for patients that went missing and found similar clinically important results (RR $0.61 ; 95 \% \mathrm{Cl} 0.49$ to 0.77 ).

$3 \mathrm{I}^{2}$ is $57 \%$ with a $\mathrm{P}$ value less than 0.0001 suggesting substantial heterogeneity. We explored the heterogeneity based on nine a priori subgroups, with probiotic dose (high versus low) demonstrating a significant subgroup to help explain the moderate heterogeneity observed. We tested the credibility of this subgroup using published criteria and determined that the subgroup demonstrating increased efficacy of high probiotic dose ( $\geq 5$ billion CFUs/day) is credible, thus we present the results for this subgroup analysis as separate row in the table.

4 Regarding inconsistency ( $\mathrm{I}^{2}$ is $57 \%$ ), given the variability in probiotic species and/or strains used, a priori we planned a subgroup analysis to explore if there were important differences in treatment effect between products with specific species and/or strains. Our subgroup analysis demonstrated no statistically significant difference between products based on our test of interaction $(P=0.94)$, demonstrating that variability in products used was a minor issue and we therefore did not rate down. However for $A A D$, given the minor issues with both risk of bias and inconsistency, we rated down once from high to moderate quality evidence.

513 of 20 studies were rated as high risk of bias due to lack of concealment of allocation, blinding, LTFU or other bias (such as sponsored by industry). 7 of 20 studies were open label or not blinded. Loss to follow-up was substantial (>20\%) in 3 studies. In particular, LTFU was $46.4 \%$ in a small study (King 2010) and 29\% in two studies that were moderate in 
size (Arvola 1999) and large in size (Erdeve 2004), respectively. However, our a priori subgroup analysis on risk of bias demonstrated no statistically significant difference between studies at high risk versus low risk of bias $(P=0.30)$. Therefore we judged risk of bias is a minor issue and we did not rate down.

6 Regarding inconsistency ( $\mathrm{I}^{2}$ is 57\%), given the variability in probiotic species and/or strains used, a priori we planned a subgroup analysis to explore if there were important differences in treatment effect between probiotic species/strains. Our subgroup analysis demonstrated no statistically significant difference between species/strains $(P=0.94)$ demonstrating that variability in products used was a minor issue and we therefore did not rate down. Given the minor issues with risk of bias and inconsistency, again for high dose probiotics ( $\geq 5$ billion CFUs/day), we rated down once from high to moderate quality evidence.

${ }^{7}$ Baseline/control group risk estimates come from pooled estimates of control groups.

8 Only 24 of 33 studies reported on adverse events, suggesting a selective reporting bias and we therefor rated down.

9 The total number of events (207) is less than 400 suggesting issues with imprecision. However, imprecision is a minor issue as adverse events are more common in the placebo group and other more comprehensive reviews specific to probiotic safety in variety of clinical settings suggest that short-term use of probiotics is safe in otherwise healthy children, with no evidence to suggest a risk of sepsis in the general population.

10 Regarding indirectness related to safety, numerous probiotic products and doses were evaluated amongst eligible trials. Overall for all studies there were more adverse events in the placebo group and we considered indirectness related to adverse events a minor issue.

11 Regarding inconsistency related to the safety of probiotics, statistical tests show considerable heterogeneity $\left(I^{2}=75 \% \mathrm{P}<0.00001\right)$, possibly due to the variability in how adverse events were captured and defined across the eligible trials; we therefor rated down for serious inconsistency.

128 of 33 trials reported duration of diarrhea, suggesting a selective reporting bias and we rated down.

13 We further rated down for inconsistency given the large statistical heterogeneity $\left(I^{2}=84 \%\right)$, very low $P$ value $\left.[P<0.00001]\right)$, and given that point estimates and confidence intervals vary considerably.

14 Only 1 study with small sample size $(n=40)$ reported microbiome characteristics, suggesting very serious imprecision and the possibility of selective reporting. We therefore rated down twice for imprecision and once for selective reporting.

15 Microbiome results are not of importance to patients and we rated down for indirectness. Further, the use of $16 \mathrm{~S}$ rRNA gene sequences to study bacterial phylogeny and taxonomy has been by far the most common test and authors did not use other suggested methods for measuring microbiome characteristics, making the results difficult to summarize and interpret for clinicians (Janda 2007; Mclnnes 2010). 


\section{B A C K G R O U N D}

\section{Description of the condition}

More than 400 species of bacteria inhabit the human gut, and a balance of these micro-organisms is important for normal gastrointestinal function (Madsen 2001). Antibiotic treatment may disturb the colonization resistance of gastrointestinal flora, resulting in a range of symptoms, most notably, diarrhea. In particular, antibiotics such as aminopenicillins, cephalosporins and clindamycin that act on anaerobes are most commonly associated with diarrhea (McFarland 2008; Owens 2008; Wistrom 2001). In addition to frequent watery bowel movements, urgency and crampy abdominal pain, antibiotic-associated diarrhea (AAD) is associated with altered intestinal microflora, mucosal integrity and vitamin/mineral metabolism (Saavedra 1999). If severe, $A A D$ may lead to electrolyte disturbances, volume depletion, pseudomembranous colitis, toxic megacolon and rarely death (Arvola 1999; Berrington 2004). Reports in the general population indicate that the incidence of AAD ranges from 5 to $62 \%$, occurring at any point from the initiation of therapy to two months after the end of treatment (LaRosa 2003; McFarland 1998; McFarland 2008; Wistrom 2001). The incidence of diarrhea in children receiving broad spectrum antibiotics has been reported in the range of 11 to $40 \%$ (Elstner 1983; Turck 2003). The overgrowth of many enteropathogens has been associated with antibioticinduced diarrhea. Clostridium difficile ( $C$. difficile) overgrowth is the bacterial agent most associated with AAD (Bartlett 1978; McFarland 1998; McFarland 2008). C. difficile diarrhea is associated with the most serious adverse events, and occurs most often in older, immunocompromised, hospitalized adults, but also occurs in children (Gogate 2005).

The definition of AAD varies across trials. Although the World Health Organization (WHO) defines diarrhea as three or more loose or liquid stools per 24 hours, the definition in pediatric trials ranges from one to three abnormally loose stools per 24 to 48 hours (Johnston 2010). Additionally, stool frequency is more difficult to quantify in diaper-aged children with diarrhea and may vary substantially between infants and older children.

\section{Description of the intervention}

Probiotics refer to so-called "friendly" non-pathogenic bacterial or yeast microbiota intended to benefit the host via altering the microflora by implantation or colonization (Schrezenmeir 2001). Probiotics have been administered both prophylactically and therapeutically in an attempt to modify the mucosal, epithelial, intestinal and systemic immune activity in ways that may benefit human health. Probiotics are reported to improve microbial balance in the intestinal tract and display both antibacterial and immune regulatory effects in humans (Gibson 1998; Goldin 1998). Probiotics commonly administered in randomized controlled trials of AAD are: Lactobacillus acidophilus, Lactobacillus bulgaris, Lactobacillus casei, Lactobacillus rhamnosus, Bifidobacteria bifidum, Bifidobacteria longum, Streptococcus thermophilus, Saccharomyces boulardii and Clostridium butyicum.

\section{How the intervention might work}

The rationale behind probiotic administration is based on re-inoculation and normalization of unbalanced indigenous microflora using specific probiotic strains.

\section{Why it is important to do this review}

Previously we demonstrated the efficacy and safety of probiotics used together with antibiotics for the prevention of $A A D$ among 23 studies including 3938 otherwise healthy children (Goldenberg 2015). This review seeks to update our 2015 review, and to further explore the study setting (e.g. inpatient, outpatient) and intervention characteristics (e.g. dose, strain(s)) that may be most effective and safe, particularly given recent concerns about inadequate reporting on the safety of probiotics in randomized trials (Bafeta 2018; Suez 2018).

\section{SAFETY OF PROBIOTICS}

Based on the bulk of the literature, the safety of diverse probiotic interventions does not appear to be a concern in healthy individuals (Borriello 2003; Hammerman 2006; Hempel 2011; Whelan 2010). Infections (e.g. bacteremia, endocarditis, septicemia, pneumonia, deep abdominal abscesses) resulting from probiotic use have been reported in neonates, and in severely debilitated and immuno-compromised individuals (Hata 1988; Land 2005; Mackay 1999; McFarland 1998; Piarroux 1999; Rautio 1999; Salminen 1998; Salminen 2004; Saxelin 1996; Sussman 1986). There is still debate on the safety of probiotics in these patients. Nevertheless, prospective studies have demonstrated the safety of probiotics in immuno-compromised adults and children with HIV and preterm neonates, with no infections secondary to probiotics reported (Bin-Nun 2005; Cunningham-Rundles 2000; Lin 2005; Salminen 2004).

Five systematic reviews have addressed the safety of Saccharomyces boulardii (S. boulardii) and other probiotics (Didary 2014; Hassan 2018; Hempel 2011; McFarland 2010; Whelan 2010). In a review of the safety of various probiotic strains and doses reported in controlled clinical trials, as well as cases series and case reports from 1984 to 2013, Didary 2014 reported two bacteraemia cases associated with Lactobacillus $G G$ and three fungemia cases in critically ill patients in the intensive care unit who had received S. boulardii. Hassan 2018 provided safety data for a total 2242 adults and children ( 25 studies) with cancer. An estimated 237 adverse events (AEs) occurred among those consuming probiotics and 314 AEs in those not consuming probiotics. Five case reports identified probiotic-related bacteraemia, fungaemia or positive blood cultures. However, based on these reviews it cannot be concluded with certainty that the observed infections were directly attributable to the probiotic consumed. A systematic review of randomized controlled trials (RCTs), reports on a wide diversity of adult patients randomized to $S$. boulardii as part of a clinical trial (traveler's diarrhea, $n=1596 ; A A D, n=958$; acute diarrhea, $n=156$; enteral tube feeding, $n=103 ;$ IBD, $n=66$; IBS, $n=16$, HIV-related diarrhea, $n=18$ and giardia infections, $n=50$ ). These studies provide safety data for a total of 2963 adult patients. The only adverse reactions associated with $S$. boulardii were thirst (n $=5$ patients) and constipation ( $n=8$ patients) in a trial of patients with C. difficile infections (McFarland 1998). No case of S. boulardii fungemia has been reported in these diverse patient populations (McFarland 2010).

A larger systematic review of case reports, randomized and non-randomized trials of probiotic safety in patients receiving nutritional support, such as enteral nutrition or parenteral nutrition, included 53 trials involving 4131 patients receiving probiotics. Most trials demonstrated either no effect or a positive effect on outcomes related to safety (e.g. infections, mortality). 
Three trials reported increased complications, which were largely noninfectious in nature and specific to patients with pancreatitis or undergoing transplant (Whelan 2010). The systematic review also reported 20 case reports of adverse events in 32 patients, 27 of which were infections due to $S$. boulardii (strain unspecified) or Lactobacillus rhamnosus GG $(n=5)$. Of the 32 patients having been administered $S$. boulardii with subsequent infections (i.e. fungemia, bacteremia), 11 of these were in children (either preterm neonates, severely debilitated or immuno-compromised children with underlying risk factors including central venous catheter use and disorders associated with bacterial or fungal translocation). Each of the children recovered after S. boulardii orLactobacillus $G G$ was discontinued, after removal of the central venous catheter $(n=7)$ and after an antibiotic or anti-fungal was administered ( $n$ $=11$ ). The authors of the study reported that these case reports likely reflect the wide use of $S$ boulardii and Lactobacillus $G G$ in clinical settings, rather than increased virulence (Whelan 2010). The largest and most comprehensive systematic review to date, assessed the safety of probiotics in human participants (with no restrictions on participant type) and included both randomized and non-randomized studies (387 studies including 24,615 total participants). Based on short-term probiotic use (compared to control group participants) the results of 208 RCTs showed no difference in the overall number of adverse events (RR 1.00;95\% Cl: $0.93,1.07$ ), including serious adverse events (RR 1.06; $95 \% \mathrm{Cl}: 0.97$, 1.16; 66 RCTs primarily based on Lactobacillus species) (Hempel 2011).

\section{O B JECTIVES}

PRIMARY

1) To systematically assess whether probiotics (any specified strain or dose) co-administered with antibiotics (any agent) reduce the incidence of antibiotic-associated diarrhea in children.

2) To systematically assess adverse events of probiotics when coadministered with antibiotics in children.

\section{SECONDARY}

1) To systematically assess which probiotic strain(s) and dose(s) yield the most beneficial results in reducing the incidence of diarrhea.

2) To systematically assess whether probiotics (any specified strain or dose) co-administered with antibiotics (any agent) reduce the duration of diarrhea.

3) To systematically assess whether probiotics (any specified strain or dose) co-administered with antibiotics (any agent) impact microbiome characteristics.

\section{METHODS}

\section{Criteria for considering studies for this review}

\section{Types of studies}

All randomized controlled trials irrespective of language or publication status, in which a specified probiotic agent has been compared to placebo, active, or no treatment control were considered for inclusion.

\section{Types of participants}

Children (0 to 18 years of age), male or female of any ethnic group being administered antibiotic therapy for any reason were considered for inclusion.

\section{Types of interventions}

Intervention group: specific, identified probiotic in any form (e.g. capsule, sachet, yogurt). Trials investigating non-specific probiotic or yogurt agents (e.g. products that do not label the probiotic strain and dose) were not considered. Trials combining probiotics with prebiotics were included if the prebiotic dose was less than 2.5 grams, as this was judged to be of limited impact to alter the gut milieu (Davis 2010; Gibson 2004; Roberfroid 1998). Control group: placebo, active, or no treatment control. All studies comparing probiotics to conventional care (i.e. diosmectite, loperamide) or probiotics plus conventional care versus conventional care plus placebo or no treatment were considered for the review.

\section{Types of outcome measures}

\section{Primary outcomes}

The primary outcomes included:

1. Incidence of diarrhea using the primary investigators' definition (i.e. frequency, consistency of bowel movements); and

2. Number and type of adverse events (e.g. bacteremia, meningitis).

\section{Secondary outcomes}

The secondary outcomes included:

1. Mean duration of diarrhea; and

2. Microbiome characteristics.

\section{Search methods for identification of studies}

\section{Electronic searches}

We searched the following databases from inception to 28 May 2018: The Cochrane Central Register of Controlled Trials (CENTRAL) on the Cochrane Library, MEDLINE, Embase, CINAHL, and Web of Science. There were no limitations on publication status or language. We also searched NICE Evidence Services (Formerly NHS Evidence) as well as ongoing trials through ClinicalTrials.gov and the ISRCTN (International Standard Randomized Controlled Trial Number Register). The search strategies are reported in Appendix 1.

\section{Searching other resources}

We searched the bibliographies of randomised controlled trials and review articles for additional studies not identified by the electronic searches.

\section{Data collection and analysis}

\section{Selection of studies}

Two authors (QG, $\mathrm{CH}$ ) independently screened the search results using titles of papers, and when available, abstracts. The full-text of the selected articles was retrieved and independently assessed for inclusion by $\mathrm{QG}$ and $\mathrm{CH}$ according to pre-specified selection criteria. Disagreement was resolved by discussion and consensus. In the event of disagreement, a third author (BJ) was consulted.

\section{Data extraction and management}

Using a standardized data extraction form two authors (QG, $\mathrm{CH}$ ) independently extracted the following data: author, year of publication, language, study setting, funding source, definition and diagnostic criteria for diarrhea, inclusion and exclusion 
criteria for participants, patient characteristics (age, gender, diagnosis, socioeconomic status), number of patients allocated to each group, presence/absence of intention to treat analysis (whether patients for whom data were available were analyzed as randomized), participants lost to follow-up (LTFU), if so, reasons for LTFU described and information about methods of imputation, measures of compliance, specified antibiotic, specified probiotic, duration, dosage and schedule of antibiotic, duration, dosage and schedule of probiotic, and outcome measures (incidence of diarrhea, number of adverse events, mean duration of diarrhea, and microbiome characteristics. For articles published in abstract form only, we obtained further information by contacting corresponding authors.

\section{Assessment of risk of bias in included studies}

Quality components for each included RCT were assessed for selection, detection, performance, reporting and loss to follow-up bias. Each of the included studies was independently evaluated by two authors $(\mathrm{QG}, \mathrm{CH})$ using the risk of bias instrument to assess each of the following domains: sequence generation, allocation concealment, blinding, incomplete outcome data, selective outcome reporting, and other sources of bias (Hartling 2009). Disagreement was resolved by discussion or a third arbitrator. We assumed that studies that had three or more domains at high or unclear risk of bias were at high risk of bias overall.

\section{Measures of treatment effect}

Using a random-effects model, dichotomous data are presented as risk ratios (RR), and continuous data as mean difference (MD), along with corresponding $95 \%$ confidence interval $(95 \% \mathrm{Cl})$. Using control event risks from the included trials, the number needed to treat for an additional beneficial outcome (NNTB) or the number needed to treat for an additional harmful outcome (NNTH) was calculated for statistically significant dichotomous outcomes. Adverse events were summarized using risk difference (RD) since these events were rare.

\section{Unit of analysis issues}

If a trial had multiple intervention arms (such as two different strains compared to placebo), we combined the two probiotic arms to make a single pair wise comparison to avoid unit of analysis errors.

\section{Dealing with missing data}

When authors neglected to report PICO related items of interest, we contacted them via email. To assess the potential influence of missing outcome responses (e.g. children lost to follow-up), sensitivity analyses were applied for the primary outcomes, incidence of diarrhea and adverse events. Although many approaches exist for evaluating the sensitivity of results for missing outcome data (Akl 2009; Hollis 1999), we elected to make assumptions about the missing data which were extreme but still plausible (i.e. $60 \%$ of children loss to follow-up in probiotic group and $20 \%$ loss to follow-up in the control group had diarrhea). See sensitivity analysis section below.

\section{Assessment of heterogeneity}

Heterogeneity was investigated using the $\mathrm{I}^{2}$ statistic (Higgins 2003). Meta-regression or the $\mathrm{Chi}^{2}$ test for heterogeneity - depending on the number of trials included - were used to address $a$ priori hypotheses explaining heterogeneity. To explore possible explanations for heterogeneity, a priori subgroup analyses were explored including: a) inpatient versus outpatient, b) diagnosis, c) probiotic species or strain(s) (when two or more trials administered the same strains), d) single strain versus multi-strain probiotics, e) dosage of probiotic ( $\geq 5$ billion colony forming units of live bacteria/ yeast, $<5$ billion colony forming units of live bacteria/yeast), f) definition of diarrhea, g) diagnostic criteria for diarrhea (moderate diarrhea was assumed to be $\geq 3$ watery/liquid stools per $24 \mathrm{hrs}$, whereas mild diarrhea was deemed to be 1 to 2 watery/liquid stools per $24 \mathrm{hrs}$ ), h) industry sponsorship, and i) quality criterion (i.e. risk of bias). We also explored heterogeneity with a post hoc subgroup based on age ( $0-2$ years [ $\leq 24$ months] versus more than 2 years of age or older [>24 months]).

\section{Assessment of reporting biases}

To evaluate the potential for publication bias, a funnel plot, was applied to the main efficacy outcome, incidence of diarrhea. If publication bias was apparent, adjustment of the pooled estimates was considered using the trim and fill method (Duval 2001).

\section{Data synthesis}

We conducted a meta-analysis as described in the measures of treatment effect and assessments of heterogeneity sections described in detail above.

We employed the GRADE system for rating overall certainty of evidence for each of the outcomes. In particular, randomized trials begin as high quality evidence, but may be rated down by one or more of five categories of limitations: (1) risk of bias, (2) consistency, (3) directness, (4) imprecision, and (5) reporting bias. The quality of evidence for each main outcome can be determined after considering each of these elements, and categorized as either high (we are very confident that the true effect lies close to that of the estimate of the effect); moderate (we are moderately confident in the effect estimate: the true effect is likely to be close to the estimate of the effect, but there is a possibility that it is substantially different); low (our confidence in the effect estimate is limited: the true effect may be substantially different from the estimate of the effect); very low (we have very little confidence in the effect estimate: the true effect is likely to be substantially different from the estimate of effect) (Guyatt 2008).

\section{Subgroup analysis and investigation of heterogeneity}

We investigated subgroups of interest as described in the 'assessment of heterogeneity' section, detailed above.

\section{Sensitivity analysis}

We conducted sensitivity analyses using a fixed-effect model as compared to random-effects, and we assessed the potential influence of missing participant outcome data as compared to a complete case analysis, with the latter described in 'dealing with missing data' section above. 


\section{RESULTS}

\section{Description of studies}

\section{Results of the search}

A previous literature search conducted in August 2006 identified 10 relevant studies for inclusion (7 English, 2 Italian, 1 French) and is described in detail elsewhere (Johnston 2007). For this review update, we searched five primary electronic databases from inception to 28 May 2018. We identified a total of 3159 studies (Medline 939, EMBASE 1282, CENTRAL 512, CINAHL 14, Web of Science 412). Additionally, a grey literature search of the NICE Evidence Services database, ISRCTN and ClinicalTrials.gov registries, as well as bibliographic review of eligible randomized trials and meta-analyses identified an additional 14 relevant studies (See Figure 1).

Figure 1. Study flow diagram.

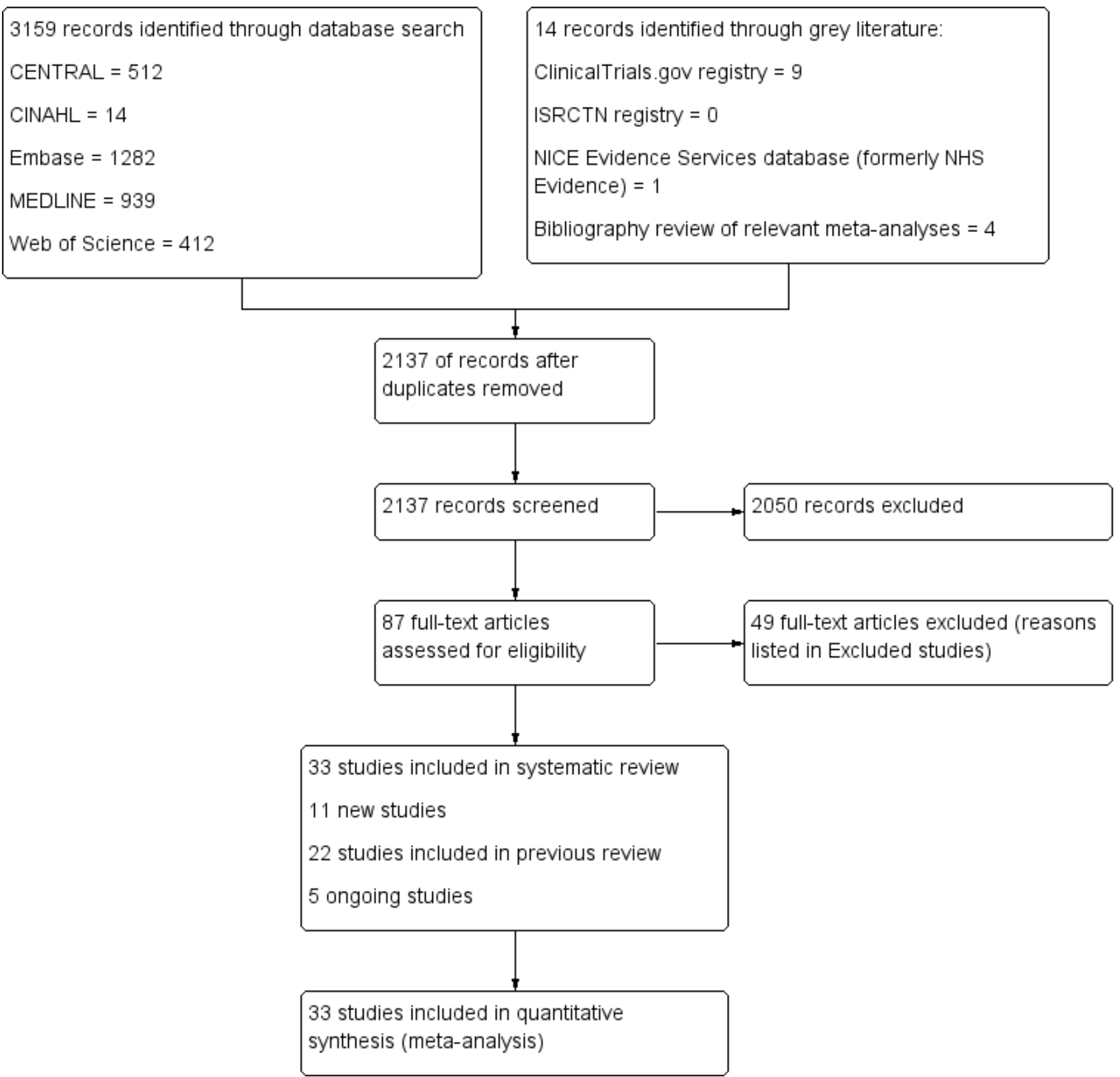

Of all of these studies, 1036 were identified as duplicates, leaving 2137 abstracts and titles identified as original publications. Independent review of these titles and abstracts identified 87 potentially relevant studies for full-text review. Three authors independently assessed these studies and identified 33 trials that met the inclusion criteria, eleven of which were new since the previous version of this review (Goldenberg 2015). Five ongoing studies were also identified. Excluded studies are described below.

\section{Included studies}

\section{Design}

All included studies were prospective, randomized, controlled trials with placebo, active or no treatment control arms. 


\section{Patient population}

For the purposes of this systematic review LTFU can be understood as incomplete ascertainment of the primary outcome for some participants in an RCT. Patients for whom data were not available for the primary outcome were classified as LTFU. After accounting for LTFU the 33 eligible studies included a total of 6352 patients (3232 treatment, 3120 controls). Patients in the trials were treated with antibiotics for upper and lower respiratory tract, or ear infections (Arvola 1999; Kotowska 2005; LaRosa 2003; Merenstein 2009; Peng 2014; Zheng 2012), Helicobacter pylori infection (Kodadad 2013; Saneeyan 2011; Szajewska 2009; Sykora 2005; Zhang 2015; Zhao 2014), mixed infections (Destura unpublished; Fox 2015; Georgieva 2015; Jindal 2017; Kolodziej 2018; Olek 2017; Ruszczynski 2008; Shan 2013; Szymanski 2008; Tankanow 1990; Vanderhoof 1999; Wan 2017; Zakordonets 2016), impetigo (Dharani 2017), hypospadias repair (Esposito 2017) and meningitis or septicemia (Jirapinyo 2002). In four studies the type of infection that necessitated antibiotic therapy was not specified (Benhamou 1999; Conway 2007; Correa 2005; Erdeve 2004). The health care setting was reported in 29 studies and consisted of: private primary care practices (Benhamou 1999; Conway 2007; Merenstein 2009; Olek 2017; Tankanow 1990; Vanderhoof 1999), hospitalized inpatients (Correa 2005; Esposito 2017; Georgieva 2015; Jirapinyo 2002; King 2010; Peng 2014; Szajewska 2009; Shan 2013; Wan 2017; Zakordonets 2016; Zheng 2012), an outpatient university teaching hospital (Arvola 1999; Dharani 2017; Jindal 2017; Kotowska 2005; Saneeyan 2011), and both inpatient and outpatient hospital populations (Destura unpublished; Kolodziej 2018; Zhao 2014). Three studies recruited from a hospital but it was unclear if the participants were inpatient or outpatient (Kodadad 2013; Sykora 2005; Zhang 2015). In addition to inpatient and outpatient hospital populations, Ruszczynski 2008 also enrolled from a private practice, and Szymanski 2008 also enrolled from outpatient clinics. King 2010 was the only trial which was conducted among hospitalized patients in the Intensive Care Unit.

Children enrolled were from families of diverse socioeconomic status, and included 17 countries: Poland (Kolodziej 2018; Kotowska 2005; Olek 2017; Ruszczynski 2008; Szymanski 2008; Szajewska 2009), the United States of America (King 2010; Merenstein 2009; Tankanow 1990; Vanderhoof 1999), China (Peng 2014; Shan 2013; Wan 2017; Zhang 2015; Zhao 2014; Zheng 2012), Iran (Kodadad 2013; Saneeyan 2011), Italy (Esposito 2017; LaRosa 2003), India (Dharani 2017; Jindal 2017), Finland (Arvola 1999), France (Benhamou 1999), England (Conway 2007), Australia (Fox 2015), Brazil (Correa 2005), the Philippines (Destura unpublished), Turkey (Erdeve 2004), Bulgaria (Georgieva 2015), Thailand (Jirapinyo 2002), Ukraine (Zakordonets 2016), and the Czech Republic (Sykora 2005). Children ranged from 3 days to 18 years of age. Twenty-six studies provided information regarding the participants' mean age: 4.5 years (Arvola 1999), 2.4 years (Benhamou 1999), 1.8 years (Correa 2005), treatment 4.1 years and control 4 years (Destura unpublished), treatment 6.8 years and control 6.3 years (Fox 2015), 8.9 years (Georgieva 2015), 9.1 years (Kodadad 2013), 1.3 years treatment and 1.2 years control (Esposito 2017), 8.5 years treatment and 8.6 years control (Zhang 2015), 11.1 days treatment and 10.9 days control (Peng 2014), 7 years treatment and 9 years control (Zhao 2014), 1.1 years (Wan 2017), 0.96 years treatment and 4.7 years control (King 2010), 5.1 years treatment and 5.2 years control (Olek 2017), 2.1 years treatment and 2.1 years control (Kolodziej 2018), 4.8 years (Kotowska 2005), 6.6 years (LaRosa 2003), 2.9 years treatment and
3.2 years control (Merenstein 2009), treatment 4.6 years and control 4.5 years (Ruszczynski 2008), treatment 8.2 years and control 9.5 years (Saneeyan 2011), 2 years (Shan 2013), treatment 12.6 years and control 12.9 years (Sykora 2005), 12.3 years treatment and 11.9 years control (Szajewska 2009), 2.5 years (Tankanow 1990), 4 years (Vanderhoof 1999), and 1.2 years (Zheng 2012). Three studies provided only the age range of enrolled participants: 3 to 14 years (Zakordonets 2016), 1 to 15 years (Dharani 2017), 6 months to 12 years (Jindal 2017), and 1 month to 3 years (Jirapinyo 2002). One study provided median age with a range: 7 years (range 1 to 15) (Szymanski 2008). Twenty-six studies included both males and females (2395 males and 1943 females), one study only included males (Esposito 2017) and seven studies did not state sufficient information regarding sex (Arvola 1999; Benhamou 1999; Conway 2007; Erdeve 2004; Jindal 2017; Jirapinyo 2002; Zhang 2015).

\section{Interventions}

Overall the trials provided between 3 and 30 days of antibiotic therapy. Most trials provided oral antibiotics.Two trials provided intravenous antibiotics to all patients (King 2010; Wan 2017). Three trials administered intravenous antibiotics to some patients (e.g. cefuroxime): 60/246 (24.3\%) (Kotowska 2005); 87/240 (36.3\%) (Ruszczynski 2008); 6/78 (7.7\%) (Szymanski 2008). Ruszczynski 2008 also provided intravenous (IV) antibiotics followed by oral antibiotics (17/240; 7.1\%) and intramuscular (IM) antibiotics (2/240; $0.8 \%)$. In five trials it was unclear what antibiotic or route was used (Conway 2007; Destura unpublished; Georgieva 2015; Merenstein 2009; Peng 2014). Six of 33 trials provided triple antibiotic therapy for H. Pylori and also followed patients for AAD (Kodadad 2013; Saneeyan 2011; Sykora 2005; Szajewska 2009; Zhang 2015; Zhao 2014).

One study provided oral amoxicillin alone (Tankanow 1990), using a standard pediatric dosage range (20 to $50 \mathrm{mg} / \mathrm{kg} /$ day), whereas the remaining trials provided a mixture of oral antibiotic agents including: bactericidal cephalosporins (e.g., cefotaxime, cefprozil), bacteriostatic macrolides (e.g., clarithromycin, erythromycin), and the bactericidal beta-lactams/penicillins. In particular, nine studies described the antibiotic classes administered. Four studies administered a host of cephalosporins $(n=341)$ and beta-lactams/ penicillins ( $\mathrm{n}=$ 931) (Benhamou 1999; Correa 2005; Destura unpublished; Kotowska 2005), one study provided cephalosporins ( $n=49$ ), beta-lactams/penicillins in the form of amoxicillinclavulanate $(n=36)$ and macrolides in the form of erythromycin $(n=34)$ (LaRosa 2003), one study provided beta-lactams $(n=64)$, macrolides $(n=5)$, and tetracyclines $(n=1)$ (Fox 2015), and one study provided beta-lactams/penicillins in the form of sulbactamampicillin $(n=234)$ and macrolides in the form of azithromycin $(n=232)$ (Erdeve 2004). Kodadad 2013 provided all participants $(n=66)$ with amoxicillin and furazolidone. Saneeyan 2011, Sykora 2005, Szajewska 2009, and Zhao 2014 provided all participants (n $=680$ ) with amoxicillin and clarithromycin. Zhang 2015 provided participants with amoxicillin and clarithromycin or metronidazole if patients were allergic to penicillin. Dharani 2017 provided all participants $(n=100)$ with azithromycin, using a dose with $10 \mathrm{mg} /$ $\mathrm{kg} /$ day, for 5 days. Esposito 2017 provided participants (84/90, 93\%) with amoxicillin in combination with clavulanate, which the first therapeutic dose $(50 \mathrm{mg} / \mathrm{kg}$ ) was given 30 min before surgery and a prophylactic dosage $(20 \mathrm{mg} / \mathrm{kg} /$ day $)$ was given after surgery. Szymanski 2008 provided cephalosporins ( $n=20)$; beta-lactams/ penicillins in the forms of penicillin, amoxicillin, or amoxicillin +clavulanate $(n=39)$; macrolides $(n=18)$; and aminoglycosides ( 
$=1)$. Zakordonets 2016 provided all participants with Ceftriaxone $(n=40)$. Ruszczynski 2008 provided cephalosporins $(n=89)$; betalactams/penicillins in the forms of penicillin, ampicillin, amoxicillin, or amoxicillin+clavulanate $(n=134)$; macrolides $(n=15)$; and clindamycin $(n=2)$. Shan 2013 provided cephalosporins $(n=173)$, beta lactams $(n=88)$, and macrolides $(n=46)$. Jindal 2017 provided co-amoxyclav ( $n=120,25-45 \mathrm{mg} / \mathrm{kg} /$ day), cefpodoxime $(\mathrm{n}=120$, $10 \mathrm{mg} / \mathrm{kg} /$ day), cefdinir $(\mathrm{n}=120,14 \mathrm{mg} / \mathrm{kg} /$ day), cefixime $(\mathrm{n}=$ $120,8 \mathrm{mg} / \mathrm{kg} /$ day), and cephalaxin ( $\mathrm{n}=120,25$ to $50 \mathrm{mg} / \mathrm{kg} /$ day). Zheng 2012 provided beta-lactams $(n=33)$, cephalosporins $(n=$ $172)$, and macrolides $(n=22)$. Olek 2017 provided penicillins $(n=$ $186)$, cephalosporins $(n=118)$, sulfometoksazole and trimethoprim $(n=32)$, and macrolides $(n=101)$. Kolodziej 2018 provided aminopenicillins $(n=63)$, cephalosporins 2 nd generation $(n=149)$, cephalosporins third generation $(n=28)$, macrolides $(n=9)$, and lincosamides $(n=1)$.

Trials included treatment with either Bacillus spp., Bifidobacterium spp., Clostridium butyricum, Lactobacilli spp., Lactococcus spp., Leuconostoc cremoris, Saccharomyces spp., orStreptococcus spp. The species or strain(s) and daily dosage of the probiotic interventions included: Lactobacillus GG, 1 billion colony forming units (CFUs) bacteria/day (Szajewska 2009); Lactobacillus GG, 20 to 40 billion CFUs bacteria per day (Arvola 1999); Lactobacillus GG, 3 billion CFUs per day (King 2010);Lactobacillus plantarum DSM 9843, 10 billion CFUs per day (Olek 2017); Lactobacillus reuteri DSM 19738, 0.2 billion CFUs per day (Kolodziej 2018); Lactobacillus rhamnosus GG ATCC53103, 5 billion CFUs per day (Esposito 2017); Lactobacillus GG and inulin (a prebiotic), 10 to 20 billion CFUs bacteria/day equalling $100 \mathrm{mg}$ and $225 \mathrm{mg}$ of the prebiotic inulin/ day (the only study to use a weight-based approach) (Vanderhoof 1999); Saccharomyces boulardii, 4.5 billion yeast/day (Benhamou 1999); Lactobacillus acidophilus and Bifidobacterium bifidus; Bifidobacterium lactis and Streptococcus thermophilus, 825 million CFUs bacteria/day (Correa 2005); Bacillus clausii, 4 billion CFUs bacteria/day (Destura unpublished);Saccharomyces boulardii, 5 billion CFUs yeast/day (Erdeve 2004; Peng 2014; Wan 2017); Lactobacillus acidophilus and Bifidobacterium infantis, dose not reported (Jirapinyo 2002); Saccharomyces boulardii, 10 billion CFUs of yeast/day (Jindal 2017; Kotowska 2005; Shan 2013; Zhang 2015; Zhao 2014); Lactobacillus sporogenes and fructo-oligosaccharide (a prebiotic); 5.5 billion CFUs bacteria/day and $250 \mathrm{mg}$ prebiotic/ day (LaRosa 2003); Lactococcus lactis, L. plantarum, L. rhamnosus, L. casei, L. lactis subspecies diacetylactis, Leuconostoc cremoris, Bifidobacterium longum, B. breve, Lactobacillus acidophilus, and Saccharomyces florentinus, at least half of a $150 \mathrm{ml}$ drink containing 7 to 10 billion CFUs bacteria and yeast/day (Merenstein 2009); Lactobacilluss rhamnosus, 40 billion CFUs bacteria/day (Ruszczynski 2008);Bifidobacterium longum PL03,Lactobacillus rhamnosus KL53A, and Lactobacillus plantarum PL02, 200 million CFUs bacteria/day (Szymanski 2008); Lactobacillus acidophilus and Lactobacillus bulgaricus, 2 billion CFUs bacteria/day (Tankanow 1990); Streptococcus thermophillus, Lactobacillus acidophilus, and Bifidobacteria anamalis subsp. lactus or Streptococcus thermophillus and Lactobacillus delbrueckii subsp. bulgaris, 1 billion CFUs bacteria/day (Conway 2007); Lactobacillus GG, 5.2 billion CFUs/day; Bifidobacterium bifidus, 5.9 billion CFUs/ day, Lactobacillus acidophilus 8.3 billion CFUs/day (Fox 2015); Lactobacillus reuteri 100 million CFUs/day (Georgieva 2015); Lactobacillus acidophilus, Lactobacillus rhamnosus, Lactobacillus bulgaricus, Lactobacillus casei, Streptococcus thermophilus, Bifidobacterium infantis and Bifidobacterium breve for a total of
1 billion CFUs/day (Kodadad 2013); Lactobacilli and Lactococci, Bifidobacterium, propionate-oxidising bacteria and acetic acid bacteria, 2 trillion CFUs/day (Zakordonets 2016); 50 million spores of Lactobacillus sporegen and 30 million spores of Streptococcus faecalis, 2 million spores of Clostridium butyricum and 1 million spores of Bacillus mesentericus, 166 million spores per day (Dharani 2017); Lactobasillus casei, Lactobacillus acidophilus, Lactobasillus reuteri, Lactobasillus bulgaricus, Streptococcus, Bifidobacterium bifidum, Bifidobacterium infantis for a total of 1 billion CFUs/day (Saneeyan 2011); Lactobacillus casei 10 billion CFUs/day (Sykora 2005); and finally Clostridium Butyricum andBifidobacterium at 2.2 billion CFUs/day (Zheng 2012).

\section{Comparison}

In 15 studies, the probiotic(s) intervention was compared to a placebo control group, two trials compared probiotics to conventional care including formula and diosmectite (Correa 2005; Benhamou 1999), eleven trials compared probiotics to no treatment (Destura unpublished; Dharani 2017; Erdeve 2004; Jindal 2017; Peng 2014; Shan 2013; Wan 2017; Zakordonets 2016; Zhang 2015; Zhao 2014; Zheng 2012), one trial compared a live probiotic drink to a heat-killed probiotics drink (Merenstein 2009), and one trial used three arms: 'bioyogurt,' commercial yogurt, and no yogurt (Conway 2007). In order to avoid unit of analysis errors, for the purposes of this review we grouped the two yogurt arms of the latter trial together. In one placebo-controlled trial, contact with authors revealed that the placebo contained an inert amount of inulin (325 mg) - a prebiotic used as capsule filler (Vanderhoof 1999). Five additional placebo-controlled trials provided information on the choice of comparison stating that the placebos contained maltodextrine, non-fat milk and saccharose, saccharum lactis,and potato starch respectively (Esposito 2017; Kotowska 2005; Olek 2017; Ruszczynski 2008; Szajewska 2009). Three trials provided information about the placebo containing sugar, lactose, and glucose respectively (Esposito 2017; Jirapinyo 2002; Tankanow 1990). Kolodziej 2018 provided the information on the placebo which consisted of 'pharmaceutical grade medium chain triglycerides and sunflower oil together with pharmaceutical grade silicon dioxide.' King 2010 did not specify details of the placebo. For the two trials involving active controls with conventional care, one trial administered diosmectite (an antidiarrheal gastrointestinal protectant drug) (Benhamou 1999), and the second administered a formula containing vitamins, minerals and protein (Correa 2005).

\section{Outcomes}

Thirty-three studies $(n=6352)$ provided data on the incidence of diarrhea, $24(n=4415)$ reported on adverse events, and 8 studies $(n=1263)$ reported on the mean duration of diarrhea. Twenty-seven studies reported the definition of diarrhea or AAD. The criteria for defining the incidence of diarrhea varied among the studies and ranged from clinical determination of diarrheal incidence (Merenstein 2009); one or more abnormally loose bowel movements per day (Tankanow 1990); at least two liquid stools per day (LaRosa 2003); two or more liquid stools per day on at least two occasions during the course of the study (Vanderhoof 1999; Wan 2017); three or more liquid/watery stools per day (Benhamou 1999; Correa 2005; Erdeve 2004; Esposito 2017; Jindal 2017; King 2010; Olek 2017; Peng 2014; Zhang 2015 ), three or more watery/ loose/liquid stools per day for two consecutive days (Arvola 1999; Conway 2007; Kotowska 2005; Zakordonets 2016); change in bowel habits with the passage of three or more liquid stools per day 
for at least two consecutive days 48 hours after initiation of antibiotic therapy (Destura unpublished); to greater than or equal to three loose or watery stools per day for a minimum of $48 \mathrm{hrs}$, occurring during or up to two weeks after the end of the antibiotic therapy (Georgieva 2015; Ruszczynski 2008; Saneeyan 2011; Shan 2013; Szajewska 2009; Szymanski 2008). Two trials used different definitions of diarrhea (Fox 2015; Kolodziej 2018). One trial used various definitions of diarrhea which included (A) stool consistency $\geq 5$ (as measured by the Bristol Stool Scale) and stool frequency $\geq 2$ /day for more than 2 days; (B) stool consistency $\geq 5$ and stool frequency $\geq 3 /$ day for more than 2 days; (C) stool consistency $\geq 6$ and stool frequency $\geq 2 /$ day for more than two days; and (D) stool consistency $\geq 6$ and stool frequency $\geq 3 /$ day for more than two days (Fox 2015). The second trial used three different definitions of diarrhea which included $(A) \geq 3$ loose or watery stools per day for a minimum of 48 hours (strictest definition); (B) $\geq 3$ loose or watery stools per day for a minimum of 24 hours; and $(C) \geq 2$ loose or watery stools per day for a minimum of 24 hours (Kolodziej 2018). One study defined diarrhea as two or more bowel movements over the patient's baseline number of bowel movements (Zheng 2012).

Five studies reported on viral and bacterial analysis of fecal samples to exclude other causes of diarrhea (Arvola 1999; Destura unpublished; Kolodziej 2018; Kotowska 2005; Wan 2017). Along with viral and bacterial fecal analysis, one trial reported on the metabolic activity of gut microflora: fecal urease, ßglucosidase and ß-glucuronidase activity (Arvola 1999) and one study reported fecal microflora compositional three different time points (Zakordonets 2016). Three trials reported on frequencies of retroviral diarrhea, salmonella diarrhea, shigella diarrhea and C. difficile diarrhea (Kolodziej 2018; Kotowska 2005; Ruszczynski 2008). Other outcomes of potential interest included mean diarrhea incubation and percentage suffering from dehydration reported in one study (Correa 2005), fecal lactoferrin (Destura unpublished), and the need for IV rehydration, hospitalisation of outpatients, or discontinuation of antibiotic treatment (Kolodziej 2018; Ruszczynski 2008; Szymanski 2008). Additionally, six studies reported on $H$. pylori outcomes such as positive rapid urea test, positive histopathology for $H$. pylori, and positive $\mathrm{C} 13$ urea breath test (Kodadad 2013; Saneeyan 2011; Sykora 2005; Szajewska 2009; Zhang 2015; Zhao 2014). No studies reported on cost-effectiveness related to absenteeism from the workplace, daycare or school between treatment and control groups.

\section{Excluded studies}

Forty-nine studies were excluded for not meeting the inclusion criteria. Reasons for exclusion are listed in the Characteristics of excluded studies tables.

\section{Risk of bias in included studies}

Loss to follow-up was substantial (i.e. > 20\%) in 6/33 trials reporting on the incidence of diarrhea (Arvola 1999; Benhamou 1999; Erdeve 2004; King 2010; Szajewska 2009; Tankanow 1990). In particular, LTFU was 46\% in King 2010, 37\% in Tankanow 1990 and 29\% in Arvola 1999. Ten trials provided a flow diagram to track participants some of which included details regarding drop-outs (Conway 2007; Kodadad 2013; Kolodziej 2018; Kotowska 2005; Merenstein 2009; Olek 2017; Ruszczynski 2008; Szajewska 2009; Szymanski 2008; Zhang 2015). All studies were randomized parallel group designs. Twenty-one studies reported using a 'double-blind' procedure. The risk of bias assessment determined that patients in the Conway 2007 and Tankanow 1990 studies were likely unblinded during treatment. Six trials were open label (Destura unpublished; Jindal 2017; Shan 2013; Zakordonets 2016; Zhang 2015; Zheng 2012). The validated risk of bias instrument categorizes risk into three categories: high risk of bias, low risk of bias and unclear. Thirteen trials were categorized as low risk (Destura unpublished; Fox 2015; Georgieva 2015; Kodadad 2013; Kolodziej 2018; Kotowska 2005; LaRosa 2003; Merenstein 2009; Olek 2017; Ruszczynski 2008; Sykora 2005; Szajewska 2009; Szymanski 2008) and 20 trials were categorized as high risk ( Arvola 1999; Benhamou 1999; Conway 2007; Correa 2005; Dharani 2017; Erdeve 2004; Esposito 2017; Jindal 2017; Jirapinyo 2002; King 2010; Peng 2014; Saneeyan 2011; Shan 2013; Tankanow 1990; Vanderhoof 1999; Wan 2017; Zakordonets 2016; Zhang 2015; Zhao 2014; Zheng 2012). See Figure 2 and Figure 3 for the overall results of the risk of bias assessment.

Figure 2. Risk of bias graph: review authors' judgements about each risk of bias item presented as percentages across all included studies.

\section{Random sequence generation (selection bias)}

Allocation concealment (selection bias)

Blinding (performance bias and detection bias)

Incomplete outcome data (attrition bias)

Selective reporting (reporting bias)
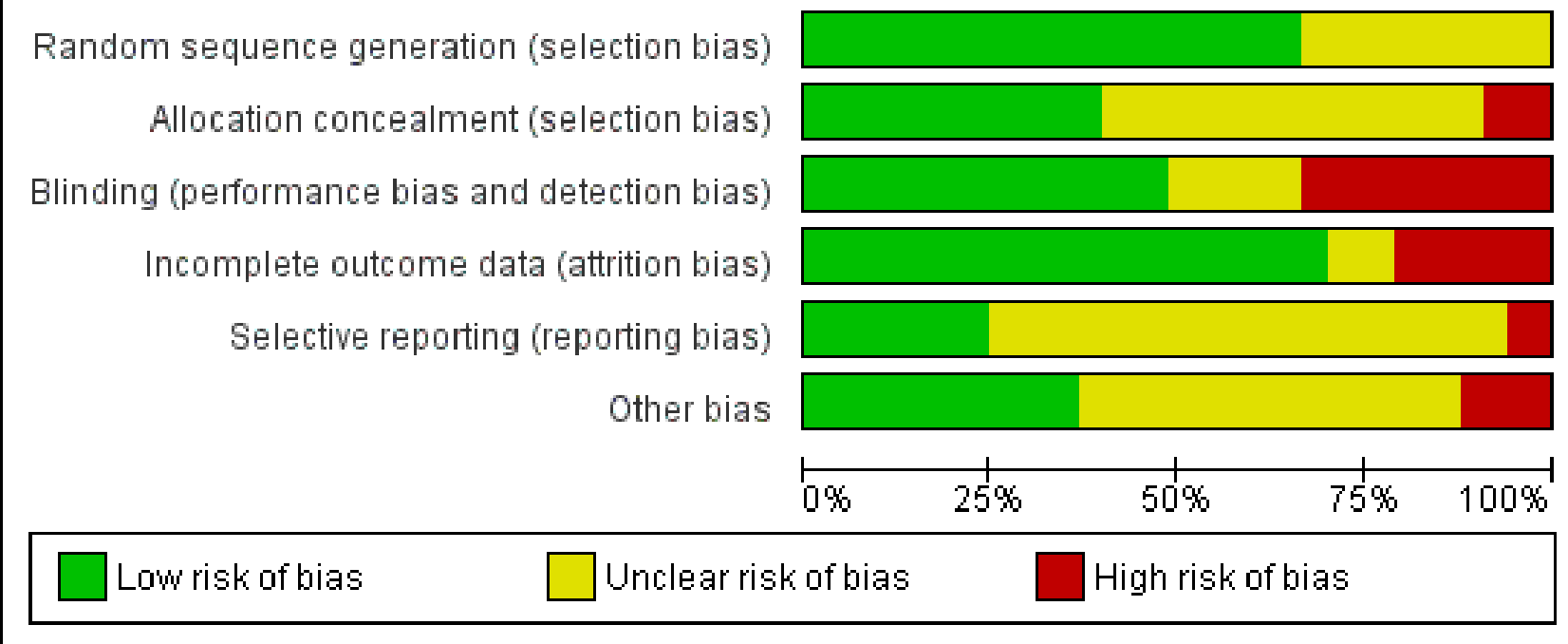
Figure 3. Risk of bias summary: review authors' judgements about each risk of bias item for each included study.

\begin{tabular}{|c|c|c|c|c|c|c|}
\hline & 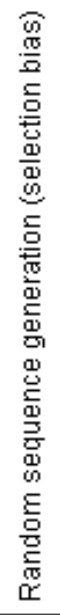 & 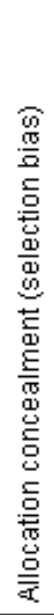 & 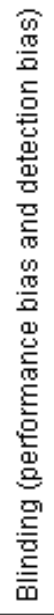 & 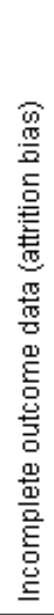 & 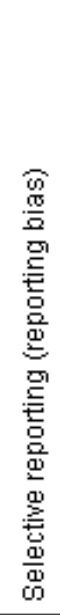 & 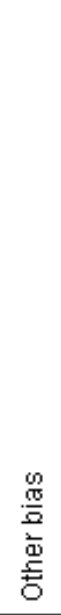 \\
\hline Arvola 1999 & + & $?$ & + & - & $?$ & + \\
\hline Benhamou 1999 & $?$ & $?$ & $?$ & - & $?$ & $?$ \\
\hline Conway 2007 & + & + & 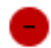 & $?$ & $?$ & + \\
\hline Correa 2005 & $?$ & $?$ & + & + & $?$ & $?$ \\
\hline Destura unpublished & + & $?$ & . & + & + & + \\
\hline Dharani 2017 & $?$ & $?$ & $?$ & + & $?$ & $?$ \\
\hline Erdeve 2004 & + & $?$ & $?$ & 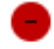 & $?$ & $?$ \\
\hline Esposito 2017 & $?$ & $?$ & $?$ & + & $?$ & $?$ \\
\hline Fox 2015 & $\oplus$ & + & + & + & + & + \\
\hline Georgieva 2015 & + & + & + & $?$ & + & \\
\hline Jindal 2017 & $?$ & $?$ & 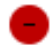 & + & $?$ & + \\
\hline Jirapinyo 2002 & $?$ & $?$ & $?$ & $?$ & $?$ & $?$ \\
\hline King 2010 & $?$ & $?$ & + & 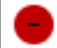 & $?$ & $?$ \\
\hline Kodadad 2013 & $?$ & $?$ & + & + & + & + \\
\hline Kolodziej 2018 & + & + & + & + & + & + \\
\hline Kotowska 2005 & + & + & + & + & $?$ & $?$ \\
\hline LaRosa 2003 & $\oplus$ & + & + & 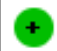 & & + \\
\hline Merenstein 2009 & $?$ & $?$ & + & + & + & + \\
\hline Olek 2017 & $\oplus$ & + & + & + & + & \\
\hline Peng 2014 & + & & & + & $?$ & $?$ \\
\hline Ruszczynski 2008 & $\oplus$ & + & + & + & ? & + \\
\hline Saneeyan 2011 & + & $?$ & $?$ & + & $?$ & $?$ \\
\hline
\end{tabular}


Figure 3. (Continued)

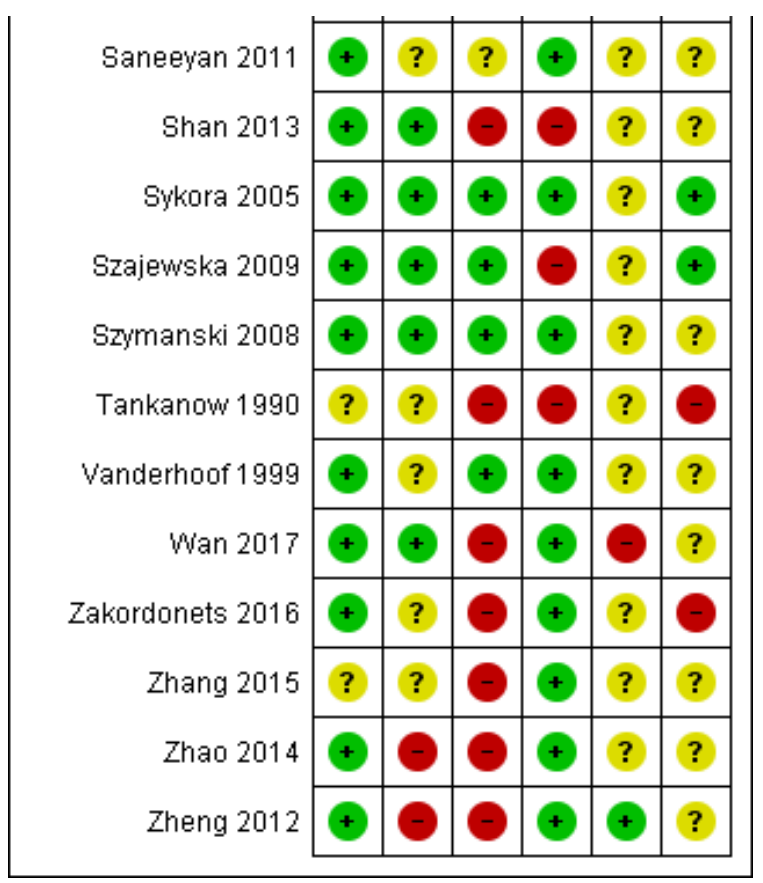

\section{Effects of interventions}

See: Summary of findings for the main comparison Probiotics as an adjunct to antibiotics for the prevention of antibiotic-associated diarrhea in children

\section{Incidence of diarrhea}

To allow for a heterogeneous definition of diarrhea, data (as a binary outcome) were included based on the primary authors' definition of the presence or absence of diarrhea. Thirty-three studies ( $n=6352$ ) reported on the incidence of diarrhea. Using an complete case (i.e. patients who did not complete the studies were not included in the analysis) approach as the primary analysis, seven placebo-controlled studies showed probiotics may reduce $(P$ $<0.05$ ) the incidence of AAD (Esposito 2017; Fox 2015; Kotowska 2005; LaRosa 2003; Ruszczynski 2008; Saneeyan 2011; Vanderhoof 1999); one active-controlled study (formula) suggested probiotics may reduce the incidence of AAD (Correa 2005), and eight 'no treatment-control' study demonstrated that probiotics may reduce the incidence of AAD (Erdeve 2004; Jindal 2017; Peng 2014; Shan 2013; Wan 2017; Zhang 2015; Zhao 2014; Zheng 2012). Twelve placebo-controlled studies (Arvola 1999; Georgieva 2015; Jirapinyo 2002; King 2010; Kodadad 2013; Kolodziej 2018; Merenstein 2009; Olek 2017; Sykora 2005; Szajewska 2009; Szymanski 2008; Tankanow 1990), four no treatment-control studies (Conway 2007; Destura unpublished; Dharani 2017; Zakordonets 2016), and one active-control (diosmectite) study (Benhamou 1999), showed no difference in the incidence of AAD. The overall pooled results using a complete case analysis showed that the use of probiotics probably produce a reduction in the incidence of AAD. After 5 days to 12 weeks of follow-up, the incidence of $A A D$ in the probiotic group was $8 \%(259 / 3232)$ compared to $19 \%(598 / 3120)$ in the active, placebo or no treatment control group (6352 participants; RR $0.45 ; 95 \% \mathrm{Cl}$ 0.36 to $0.56 ; \mathrm{P}<0.00001$; random-effects). However, substantial heterogeneity was detected $(P<0.00001)$ and this was moderate with respect to per cent variability due to between (or inter -) study variability $\left(I^{2}=57 \%\right)$ (Higgins 2003). A GRADE analysis indicated that the overall quality of evidence for the outcome incidence of diarrhea was moderate due to minor issues with risk of bias and inconsistency (see Summary of findings for the main comparison).

\section{Adverse events}

None of the studies specifically defined adverse events a priori. Among 33 included studies, 25 followed and reported on adverse events including 13 studies reporting that no adverse events were observed (Conway 2007; Destura unpublished; Jindal 2017; Jirapinyo 2002; King 2010; Kotowska 2005; Ruszczynski 2008; Shan 2013; Szymanski 2008; Vanderhoof 1999; Wan 2017; Zakordonets 2016; Zheng 2012), and twelve trials reported a variety of adverse events, typically mild to moderate in nature (Correa 2005; Dharani 2017; Fox 2015; Kodadad 2013; Kolodziej 2018; Merenstein 2009; Olek 2017; Peng 2014; Sykora 2005; Szajewska 2009; Tankanow 1990; Zhao 2014). Among the 12 studies having reported specific adverse events, 11 reported incidence rates while 1 reported a rate ratio (Zhao 2014). For the purpose of meta-analysis, we only included studies reporting incidence rates.

The characteristics of the 11 studies reporting incidence data follows. Correa 2005 reported five participants with adverse events in the treatment group. These adverse events were related to the tolerability of a baby formula supplemented with probiotics. Dharani 2017 reported five adverse events in the treatment and nine adverse events in the control group, including flatulence, abdominal discomfort and vomiting. Fox 2015 reported 14 participants with adverse events (i.e. abdominal pain, loss of appetite, nausea, vomiting and headache) with more adverse events reported in the control group than the probiotic group. Kodadad 2013 reported 18 participants with adverse events 
including nausea, vomiting, and abdominal bloating, again with more adverse events occurring in the control group than the probiotic group. Kolodziej 2018 reported three adverse events in probiotic group and seven adverse events in control group. In both groups adverse events included abdominal pain, regurgitation and 'flexing'. Merenstein 2009 reported a case of emesis in the treatment group and a case of constipation in the control group. Sykora 2005 reported seven adverse events in the probiotic group and nine adverse events in the control group. However, eight of the reported adverse events were diarrhea (four in each group) which we counted as our primary outcome. This left four participants with non-diarrhea adverse events in each group. No difference in adverse events was found between groups ( $<<0.0001)$. Olek 2017 reported 155 adverse events in 99/447 participants randomized, of which 39 participants in treatment group and 60 participants in control group experienced at least 1 adverse event. The incidence of participants with at least one adverse event was significantly lower in the treatment group compared with the placebo-control group. Szajewska 2009 reported 18 adverse events in the treatment group and 13 in the control group. In both groups adverse events included nausea, vomiting, constipation, flatulence, taste disturbance, and low appetite. Peng 2014 reported adverse events including antibiotic allergic reaction and mycotic stomatitis. However, it was assumed for the purpose of our metaanalysis that the antibiotic allergic reaction was not related to the probiotics. Therefore, three adverse events were found in the control group and zero adverse events were found in the treatment group. Tankanow 1990 reported 14 adverse events experienced by 3 patients including rash, gas, vomiting, increased phlegm and chest pain. However, for each of the 14 events it was not clear in which group (treatment or control) the adverse events occurred. Based on the study report, it appears that the 14 adverse events occurred in 3 participants receiving probiotic.

The characteristics of the one trial reporting a rate ratio are as follows. Among 240 patients randomized, Zhao 2014 reported 95/120 adverse events in treatment group and 140/120 adverse events in control group. The adverse events including nausea, vomiting, stomatitis, abdominal pain and constipation. However the author did not report evidence of association between observed adverse events and probiotic. We contacted the author for the number of patients with at least one or more adverse events in each group (treatment and control) and no response was received.

Meta-analysis of 24 trials (4415 participants) that followed participants for adverse events demonstrated no differences in the incidence of adverse events. After 5 days to 4 weeks of followup, $4 \%(86 / 2229)$ of participants in probiotic group had adverse events compared to $6 \%(121 / 2186)$ of participants in control group (RD $0.00 ; 95 \% \mathrm{Cl}-0.01$ to $0.01, \mathrm{P}<0.00001$ ), demonstrating that there were slightly more adverse events in the control group. A GRADE analysis indicated that the overall quality of evidence for this outcome was low due to imprecision (sparse data, only 207 events), indirectness related to intervention and measurement of adverse outcomes, inconsistency $\left(I^{2}=75 \%\right)$ and potential selective reporting given that only 25 of 33 studies reported AEs (see Summary of findings for the main comparison).

\section{Mean duration of diarrhea}

Eight studies recorded the mean duration of diarrhea (Arvola 1999; Correa 2005; Destura unpublished; Esposito 2017; LaRosa
2003; Peng 2014; Vanderhoof 1999; Zhang 2015). The standard deviation (SD) for two of the eight trials was not reported (Esposito 2017; Vanderhoof 1999). The SD of the two trials (Esposito 2017; Vanderhoof 1999), was imputed based on median of observed SD values from other 6 trials (Arvola 1999; Correa 2005; Destura unpublished; LaRosa 2003; Peng 2014; Zhang 2015). A post hoc sensitivity analysis was conducted to test the robustness of the mean duration results both before and after imputing data. The MD was statistically significant both before including Vanderhoof 1999 (MD -0.80; 95\% Cl -1.42 to $-0.18 ; 1015$ participants) and after imputing the SD data (MD $-0.91,95 \%-1.38$ to $-0.44 ; 1263$ participants). Substantial heterogeneity was detected $(P<0.00001)$ and this was high with respect to per cent variability due to between (or inter - ) study variability $\left(I^{2}=84 \%, P<0.00001\right)$ (Higgins 2003). A GRADE analysis indicated that the overall quality of evidence for this outcome was low due to serious inconsistency $\left(I^{2}=84 \%\right)$ and potential selective reporting bias given that only 8 of 33 trials reported on duration of diarrhea (see Summary of findings for the main comparison).

\section{Microbiome characteristics}

One study reported on metabolic activity of the gut microflora (i.e. fecal urease, beta-glucuronidase, beta-glucosidase) at baseline, three weeks, one month and three months (Arvola 1999), however, authors did not report changes between groups. Since the Arvola 1999 data are specific to enzymatic activity of the microflora, we did not consider this directly relevant to microbiome characteristics. A second study that assessed five probiotic species including Lactobacilli, Lactococci, Bifidobacterium (strain not specified) versus no treatment (antibiotic only) reported fecal microflora composition changes in microbiome at baseline, one day after discontinuation of antibiotic, and one month after discontinuation (Zakordonets 2016). Authors reported that probiotics may lead to differences between the probiotic and the antibiotic only group with respect to total E. coli, lactose (-) and hemolytic E. coli, and Staphylloccus aureas at one day after discontinuation of antibiotic $(P<0.05)$. At one month, authors also reported probiotics may lead to slight differences in lactose (-) and hemolytic E. coli, Staphylloccus aureas, Candida spp and Klebsiella pneumoniae ( $\mathrm{P}$ $<0.05$ ). There were no differences in changes in Lactobacillus spp or Bifidobacterium spp $(\mathrm{P}<0.05)$. No studies reported 16SrRNA or other microbiome analyses. GRADE analysis indicated that overall quality of evidence for this outcome was very low due to selective reporting, imprecision, and indirectness (outcome not of importance to patients).

\section{A PRIORI SUBGROUPS}

\section{Inpatient versus outpatient}

Twenty-three studies clearly delineated whether or not their populations were inpatient or outpatient. Eleven studies were conducted in an outpatient setting (Benhamou 1999; Conway 2007; Correa 2005; Dharani 2017; Fox 2015; Jindal 2017; Merenstein 2009; Olek 2017; Saneeyan 2011; Tankanow 1990; Vanderhoof 1999). Ten studies were conducted amongst inpatient populations (Esposito 2017; Georgieva 2015; Jirapinyo 2002; King 2010; Peng 2014; Shan 2013; Szajewska 2009; Wan 2017; Zakordonets 2016; Zheng 2012). Seven studies had mixed inpatients and outpatient populations (Arvola 1999; Destura unpublished; Kolodziej 2018; Kotowska 2005; Ruszczynski 2008; Szymanski 2008; Zhao 2014). Both outpatient studies and inpatient studies showed a statistically significant 
effect. Seven per cent (54/750) of inpatients in the probiotic group had diarrhea compared to $24 \%$ (171/719) of inpatients in the control group (RR $0.34 ; 95 \% \mathrm{Cl} 0.26$ to 0.45 ). Eight per cent (99/1273) of outpatients in the probiotic group had diarrhea compared to $17 \%$ (200/1207) of outpatients in the control group (RR 0.54; 95\% Cl 0.33 to 0.88 ); in both instances probiotics reduced diarrhea. A test for interaction between in and outpatient trials was not statistically significant $\left(P=0.21 ; I^{2}=57.7 \%\right)$.

\section{Diagnosis}

Twenty-nine studies reported on the participants' diagnoses which had necessitated the antibiotics. Dharani 2017 was limited to patients with impetigo. Esposito 2017 was limited to hypospadias. Six studies ( $n=1064$ ) were limited to respiratory infections (Arvola 1999; Merenstein 2009; LaRosa 2003; Kotowska 2005; Peng 2014; Zheng 2012), of which $16 \%$ (58/532) of patients diagnosed with respiratory infections in probiotic group had diarrhea compared to $26 \%(136 / 532)$ in control group (RR $0.44 ; 95 \% \mathrm{Cl} 0.33$ to 0.61 ; $\mathrm{P}$ $<0.00001)$. Six studies $(n=700)$ were limited to participants with H. pylori infections (Kodadad 2013; Saneeyan 2011; Sykora 2005; Szajewska 2009; Zhang 2015; Zhao 2014), of which 14\% (49/353) of patients diagnosed with $\mathrm{H}$. pylori infection in probiotic group had diarrhea compared to $30 \%(105 / 347)$ in control group (RR $0.48 ; 95 \% \mathrm{Cl} 0.35$ to $0.64 ; \mathrm{P}<0.00001)$. Fifteen studies $(\mathrm{n}=3083$ ) had participants with a variety of infections (Destura unpublished; Fox 2015; Georgieva 2015; Jindal 2017; Jirapinyo 2002; King 2010; Kolodziej 2018; Olek 2017; Ruszczynski 2008; Shan 2013; Szymanski 2008; Tankanow 1990; Vanderhoof 1999; Wan 2017; Zakordonets 2016), of which $6 \%(89 / 1542)$ of patients in probiotic group had diarrhea compared to $17 \%(258 / 1541)$ in control group (RR 0.43; $95 \% \mathrm{Cl} 0.27$ to $0.67 ; \mathrm{P}<0.0001)$. A test for interaction was not statistically significant $\left(P=0.91 ; I^{2}=0 \%\right)$.

\section{Probiotic species}

Six of 33 trials administered Lactobacillus rhamnosus species (five using strain Lactobacillus GG: Arvola 1999; Esposito 2017; King 2010; Szajewska 2009; Vanderhoof 1999; and one using strains $\mathrm{E} / \mathrm{N}$, Oxy, and Pen: Ruszczynski 2008), while nine studied the yeast Saccharomyces boulardii (Benhamou 1999; Erdeve 2004; Jindal 2017; Kotowska 2005; Peng 2014; Shan 2013; Wan 2017; Zhang 2015; Zhao 2014). Combined results from six L. rhamnosus studies ( $n=686$ ) showed a statistically significant protective effect. Eight per cent (27/345) of L. rhamnosus participants had diarrhea compared to $22 \%(76 / 341)$ of the control group, (RR $0.37,95 \%$ $\mathrm{Cl} 0.24$ to $\left.0.55 ; \mathrm{P}<0.0001 ; \mathrm{I}^{2}=0 \%\right)$. The summary statistic for Saccharomyces boulardii trials $(n=3165)$ was statistically significant as well indicating a protective effect. Eight per cent (125/1620) of Saccharomyces boulardii participants had diarrhea compared to $21 \%(329 / 1545)$ in control group (RR $0.36 ; 95 \% \mathrm{Cl} 0.24$ to 0.54 ; $\left.\mathrm{P}<0.0001 ; I^{2}=76 \%\right)$. A test of interaction for species related heterogeneity between $L$. rhamnosus species and $S$. boulardii revealed no statistically significant difference $\left(P=0.94, I^{2}=0 \%\right)$.

\section{Single strain versus multi-strain probiotics}

Of the 33 studies reporting on incidence of diarrhea, 20 studies used a single strain (Arvola 1999; Benhamou 1999; Destura unpublished; Erdeve 2004; Esposito 2017; Georgieva 2015; Jindal 2017; King 2010; Kolodziej 2018; Kotowska 2005; LaRosa 2003; Olek 2017; Peng 2014; Shan 2013; Sykora 2005; Szajewska 2009; Vanderhoof 1999; Wan 2017; Zhang 2015; Zhao 2014), four studies used two strains
(Correa 2005; Jirapinyo 2002; Tankanow 1990; Zheng 2012), three studies used three strains (Fox 2015; Ruszczynski 2008; Szymanski 2008), three studies used four strains (Conway 2007; Dharani 2017; Zakordonets 2016), two studies used seven strains (Kodadad 2013; Saneeyan 2011), and one study used 10 strains (Merenstein 2009). Single strain probiotics (20 studies, $n=4900$ ) and multi-strain probiotics (13 studies, $n=1452$ ) showed a statistically significant effect. Seven per cent (184/2483) of single strain participants had diarrhea compared to $18 \%(446 / 2417)$ of the control group (RR $0.42,95 \% \mathrm{Cl} 0.32$ to $0.56 ; \mathrm{P}<0.00001)$. Ten per cent $(75 / 749)$ of multi-strain participants had diarrhea compared to $22 \%(152 / 703)$ of the control group (RR $0.53 ; 95 \% \mathrm{Cl} 0.37$ to $0.75 ; \mathrm{P}=0.0003$ ). $\mathrm{A}$ test for interaction between these two groups was not statistically significant $\left(P=0.34 ; 1^{2}=0 \%\right)$.

\section{Probiotic dose}

The daily dosage of probiotic(s) varied greatly from 100 million to 2 trillion CFUs/day. Thirty-two of 33 studies that reported on the incidence of diarrhea, provided dosage information (Arvola 1999; Benhamou 1999; Conway 2007; Correa 2005; Destura unpublished; Erdeve 2004; Esposito 2017; Fox 2015; Georgieva 2015; Jindal 2017; Jirapinyo 2002; King 2010; Kodadad 2013; Kolodziej 2018; Kotowska 2005; LaRosa 2003; Merenstein 2009; Olek 2017; Peng 2014; Ruszczynski 2008; Saneeyan 2011; Shan 2013; Sykora 2005; Szajewska 2009; Szymanski 2008; Tankanow 1990; Vanderhoof 1999; Wan 2017; Zakordonets 2016; Zhang 2015; Zhao 2014; Zheng 2012). The a priori subgroup analyses on dose compared $<5$ billion CFUs/day versus $\geq 5$ billion CFUs/day. Twenty studies $(n=4038$ ) providing children with 5 billion to 2 trillion bacteria/yeast cells per day showed evidence for the preventative effects of probiotics (Arvola 1999; Erdeve 2004; Esposito 2017; Fox 2015; Jindal 2017; Kotowska 2005; LaRosa 2003; Merenstein 2009; Olek 2017; Peng 2014; Ruszczynski 2008; Shan 2013; Sykora 2005; Vanderhoof 1999; Wan 2017; Zakordonets 2016; Zhang 2015; Zhao 2014). For the high dose studies, the pooled incidence of AAD in the probiotic group was $8 \%$ (162/2029) compared to $23 \%(462 / 2009)$ in the active, placebo or no treatment control group (RR $0.37,95 \% \mathrm{Cl} 0.30$ to 0.46 , $\mathrm{P}<0.00001, \mathrm{I}^{2}=36 \%$, moderate certainty evidence; See Summary of findings for the main comparison). Twelve studies ( $n=2214$ ) providing < 5 billion CFUs bacteria/yeast per day: 825 million CFUs/ day (Correa 2005), 200 million CFUs/day (Kolodziej 2018; Szymanski 2008), 100 million CFUs/day (Georgieva 2015), 4.5 billion CFUs/ day (Benhamou 1999), 4 billion CFUs/day (Destura unpublished), 2.2 billion CFUs/day (Zheng 2012), 2 billion CFUs/day (Tankanow 1990), and 1 billion CFUs/day (Conway 2007; Szajewska 2009; Saneeyan 2011; Kodadad 2013), and demonstrated statistically non-significant results when combined. For the low dose studies the pooled incidence of $A A D$ in the probiotic group was $8 \%$ $(97 / 1155)$ compared to $13 \%(133 / 1059)$ in the active, placebo or no treatment control group (RR $0.68 ; 95 \% \mathrm{Cl} 0.46$ to $1.01 ; \mathrm{P}=0.06$; $\left.1^{2}=53 \%\right)$. A test for interaction revealed a statistically significant dose-related heterogeneity $\left(P=0.01 ; I^{2}=85.1 \%\right)$. Using 5 criteria to evaluate the credibility of the subgroup analysis, the results indicate that the subgroup effect based on dose ( $\geq 5$ billion CFUs/ day) was convincing (Sun 2014; See Appendix 2).

\section{Definition of diarrhea}

Among the 27 studies reporting on the definition of diarrhea onset (diagnosis), we assessed for subgroup differences based on the variability of the definition. Among studies (13 studies, $n=1873$ ) defining diarrhea as 3 or more loose/water/liquid stools per day 
for at least 2 consecutive days, $6 \%$ (58/956) of the probiotic group had diarrhea compared to $19 \%$ (170/917) of the control group (RR $0.36,95 \% \mathrm{Cl} 0.25$ to $\left.0.50 ; \mathrm{P}<0.00001 ; \mathrm{I}^{2}=15 \%\right)$. Among studies (9 studies, $n=2748$ ) defining diarrhea as $\geq 3$ watery/liquid stools per 24 hours, $8 \%(106 / 1408)$ of the probiotic group had diarrhea compared to $17 \%(228 / 1340)$ of the control group (RR $0.48,95 \% \mathrm{Cl} 0.31$ to 0.76 ; $\left.P=0.0002 ; I^{2}=73 \%\right)$. A test for interaction by diarrhea definition was not statistically significant $\left(P=0.30,1^{2}=7 \%\right)$.

\section{Strictness of definition of diarrhea (mild vs moderate)}

Similarly, we assessed for subgroup differences based on categorizing the study definition of AAD as either mild or moderate severity. Among studies (20 studies, $n=4303$ ) defining diarrhea as moderate severity, $7 \%(148 / 2207)$ of the probiotic group had diarrhea compared to $17 \%$ (365/2097) of the control group (RR 0.40, $95 \% \mathrm{Cl} 0.31$ to $0.53 ; \mathrm{P}<0.00001 ; \mathrm{I}^{2}=46 \%$ ). Among studies ( 5 studies, $\mathrm{n}=1104)$ defining diarrhea as mild severity, $9 \%(51 / 562)$ in probiotic group had diarrhea compared to $25 \%(134 / 542)$ in control group (RR $0.41,95 \% \mathrm{Cl} 0.22$ to $0.77 ; \mathrm{P}=0.005, \mathrm{I}^{2}=81 \%$ ). A test for interaction by strictness was not statistically significant $\left(P=0.95, \mathrm{I}^{2}=0 \%\right)$.

\section{Industry sponsorship}

Seventeen studies clearly reported on study sponsorship or funding. Of these, 9 studies ( $n=1627$ ) were funded by industry (Correa 2005; Destura unpublished; Merenstein 2009; Olek 2017; Ruszczynski 2008; Sykora 2005; Tankanow 1990; Vanderhoof 1999; Zakordonets 2016) and $8(n=1315)$ were not (Conway 2007; Dharani 2017; Fox 2015; Jindal 2017; Kolodziej 2018; Saneeyan 2011; Szajewska 2009; Szymanski 2008). Industry sponsored studies showed statistically significant effects as did non-industry sponsored studies. Among industry sponsored studies, 8\% (62/804) of the probiotic group had diarrhea compared to $15 \%(126 / 823)$ of the control group (RR $0.58,95 \% \mathrm{Cl} 0.40$ to $0.82 ; \mathrm{P}=0.003 ; \mathrm{I}^{2}$ $=39 \%)$. Among non-industry sponsored studies $6 \%(44 / 680)$ of the probiotic group had diarrhea compared to $18 \%(112 / 635)$ in control group (RR $0.43 ; 95 \% \mathrm{Cl} 0.18$ to $1.00 ; \mathrm{P}=0.05, \mathrm{I}^{2}=70 \%$ ). A test for interaction between these two groups was not statistically significant $\left(P=0.52, I^{2}=0 \%\right)$.

\section{Risk of bias}

Of the 33 studies reporting on incidence of diarrhea, 13 studies ( $n=$ 2170) were rated as having a low risk of bias (Destura unpublished; Fox 2015; Georgieva 2015; Kodadad 2013; Kolodziej 2018; Kotowska 2005; LaRosa 2003; Merenstein 2009; Olek 2017; Ruszczynski 2008; Sykora 2005; Szajewska 2009; Szymanski 2008), and 20 studies $(n=4182)$ were rated as having a high risk of bias (Arvola 1999; Benhamou 1999; Conway 2007; Correa 2005; Dharani 2017; Erdeve 2004; Esposito 2017; Jindal 2017; Jirapinyo 2002; King 2010; Peng 2014; Saneeyan 2011; Shan 2013; Tankanow 1990; Vanderhoof 1999; Wan 2017; Zakordonets 2016; Zhang 2015; Zhao 2014; Zheng 2012). A subgroup analysis of those trials rated as a low risk of bias versus those rated as exhibiting a high risk of bias showed statistically significant results for the low risk of bias studies and the high risk of bias studies. Among low risk of bias studies, $7 \%(70 / 1076)$ of the probiotic group had diarrhea versus $13 \%$ $(139 / 1094)$ of the control group (RR $0.53 ; 95 \% \mathrm{Cl} 0.37$ to $0.77 ; \mathrm{P}=$ $\left.0.0007, \mathrm{I}^{2}=32 \%\right)$. Among high risk of bias studies $9 \%(189 / 2158)$ of the probiotic group had diarrhea compared to 23\% (459/2024) of the control group (RR $0.42 ; 95 \% \mathrm{Cl} 0.31$ to $0.56 ; \mathrm{P}<0.00001, \mathrm{I}^{2}=$
$66 \%)$. A test for interaction was not statistically significant $(P=0.30$; $\left.\mathrm{I}^{2}=8.7 \%\right)$.

\section{POST HOC SUBGROUPS}

\section{Age $\leq \mathbf{2 4}$ months versus $>\mathbf{2 4}$ months}

Thirty-two ( $n=5752$ ) of 33 studies reported on age. Based on the largest prospective cohort study we are aware of (Turck 2003), the risk of AAD based 650 outpatient children prescribed antibiotics is $18 \%$ in children $\leq 24$ months, and $3 \%$ in children $>24$ months. We assessed for subgroup difference based on these age groups. Of these, six studies $(n=1127)$ reported on the participants' age $\leq 24$ months (Correa 2005; Esposito 2017; Jirapinyo 2002; Peng 2014; Wan 2017; Zheng 2012), while 26 studies $(n=4625)$ enrolled participants $>24$ months of age (Arvola 1999; Benhamou 1999; Conway 2007; Destura unpublished; Dharani 2017; Erdeve 2004; Fox 2015; Georgieva 2015; King 2010; Kodadad 2013; Kolodziej 2018; Kotowska 2005; LaRosa 2003; Merenstein 2009; Olek 2017; Ruszczynski 2008; Saneeyan 2011; Shan 2013; Sykora 2005; Szajewska 2009; Szymanski 2008; Tankanow 1990; Vanderhoof 1999; Zakordonets 2016; Zhang 2015; Zhao 2014). For the participants $\leq 24$ months of age the pooled incidence of $A A D$ in the probiotic group was $9 \%(50 / 580)$ compared to $25 \%(136 / 547)$ in the active, placebo or no treatment control group (RR $0.37 ; 95 \% \mathrm{Cl}$ 0.26 to $\left.0.53 ; P=0.24 ; I^{2}=26 \%\right)$. For those participants $>24$ months of age the pooled incidence of AAD in the probiotic group was $8 \%$ (193/2354) compared to $17 \%(390 / 2271)$ in the active, placebo or no treatment control group (RR $0.50 ; 95 \% \mathrm{Cl} 0.39$ to $0.66 ; \mathrm{P}=0.0006 ; \mathrm{I}^{2}$ $=54 \%)$. A test for interaction was not statistically significant $(P=0$. $\left.18 ; I^{2}=43.3 \%\right)$.

\section{SENSITIVITY ANALYSES}

\section{Random-effects versus fixed-effect}

A sensitivity analysis using random-effects (RR 0.45; 95\% Cl 0.36 to $0.56 ; \mathrm{P}<0.00001 ;\left.\right|^{2}=57 \%$ ) versus fixed-effect models (RR 0.43; $95 \% \mathrm{Cl} 0.37$ to $0.49 ; \mathrm{P}<0.00001, \mathrm{I}^{2}=57 \%$ ) for the incidence of diarrhea, indicated limited differences between the risk ratio and corresponding 95\% confidence intervals. Nonetheless, because the $\mathrm{I}^{2}$ statistic demonstrated moderate heterogeneity within and between studies, a random-effects model was used for all statistical analyses.

\section{Imputation for missing outcome data analysis}

\section{Incidence of diarrhea analysis}

There were 6352 pediatric participants originally randomized in the 33 trials reporting on the primary outcome (incidence of diarrhea). Twenty of 33 trials reported LTFU of which six reported substantial attrition concerns. Loss to follow-up was 20\%, 21\%, 28\%, 28\%, 36\% and 46.4\% in the Szajewska 2009; Arvola 1999; Benhamou 1999; Erdeve 2004; Tankanow 1990 and King 2010 studies respectively. We elected to make assumptions about the missing data which were extreme but still plausible. If no information was reported on the number of patients randomized to each group, or the number LTFU from each group (e.g. not reported in the published trial or unsuccessful contact with authors) was available, it was assumed that the LTFU in the treatment and control groups were as even as possible (e.g. block randomization). After imputing data for the missing responses, an extreme-plausible analysis (60\% of children loss to follow-up in probiotic group and $20 \%$ loss to follow-up in the control group had diarrhea) resulted in a probable slight 
reduction in the incidence of $A A D$. For this sensitivity analysis, the pooled incidence of AAD in the probiotic group was $12 \%$ (436/3551) compared to $19 \%(664 / 3468)$ in the active, placebo or no treatment control group (RR $0.61 ; 95 \% \mathrm{Cl} 0.49$ to $\left.0.77 ; \mathrm{P}<0.00001 ;\left.\right|^{2}=70 \%\right)$. For high dose probiotics, the extreme plausible analysis for LTFU also showed that the probiotics probably reduce the incidence of $A A D$ (RR 0.54; $95 \% \mathrm{Cl} 0.42$ to $0.70 ; \mathrm{P}<0.00001 ; \mathrm{I}^{2}=68 \%$ ).

\section{Adverse event analysis}

Assuming that patients LTFU in each of the trials may have had adverse events, we conducted a sensitivity analysis to test the robustness of the primary available case analysis. To do so, we decided that a reasonable assumption to make for those who were LTFU was that LTFU had the same adverse event rate as those followed up in their respective randomization groups. In particular, among the 24 trials that did report on adverse events, the proportion of adverse events was 3.9\% (86/2229) in the treatment group and $121 / 2186(5.5 \%)$ in the control group. For trials that reported LTFU, we assigned the same adverse event rate as those followed up in their respective randomization groups, that is $3.8 \%(88 / 2331)$ and $5.4 \%(123 / 2264)$ were assumed to have adverse events among treatment and control groups, respectively. Our primary complete case analysis (RD $-0.00 ; 95 \% \mathrm{Cl}-0.01$ to $0.01 ; \mathrm{P}<0.00001$ ) yielded the same pooled estimate as the same event rate assumptions analysis (RD $0.00 ; 95 \% \mathrm{Cl}-0.01$ to 0.01 ; $\mathrm{P}<$ $0.00001)$.

\section{Publication bias}

A funnel plot analysis provided no compelling visual indication of publication bias showing general symmetry of the funnel for the relationship between risk ratio and standard error (See Figure 4 and Figure 5). Because of the heterogeneity in our sample $\left(\mathrm{Tau}^{2}=\right.$ 0.21 ), we followed recently proposed guidelines and chose not to run statistical tests of publication bias such as Egger's regression test (Sterne 2011).

\section{Figure 4. Funnel plot of comparison: 1 any specific probiotic versus control (placebo, active or no treatment),} outcome: 1.6 Incidence of Diarrhea: Complete case - fixed effects

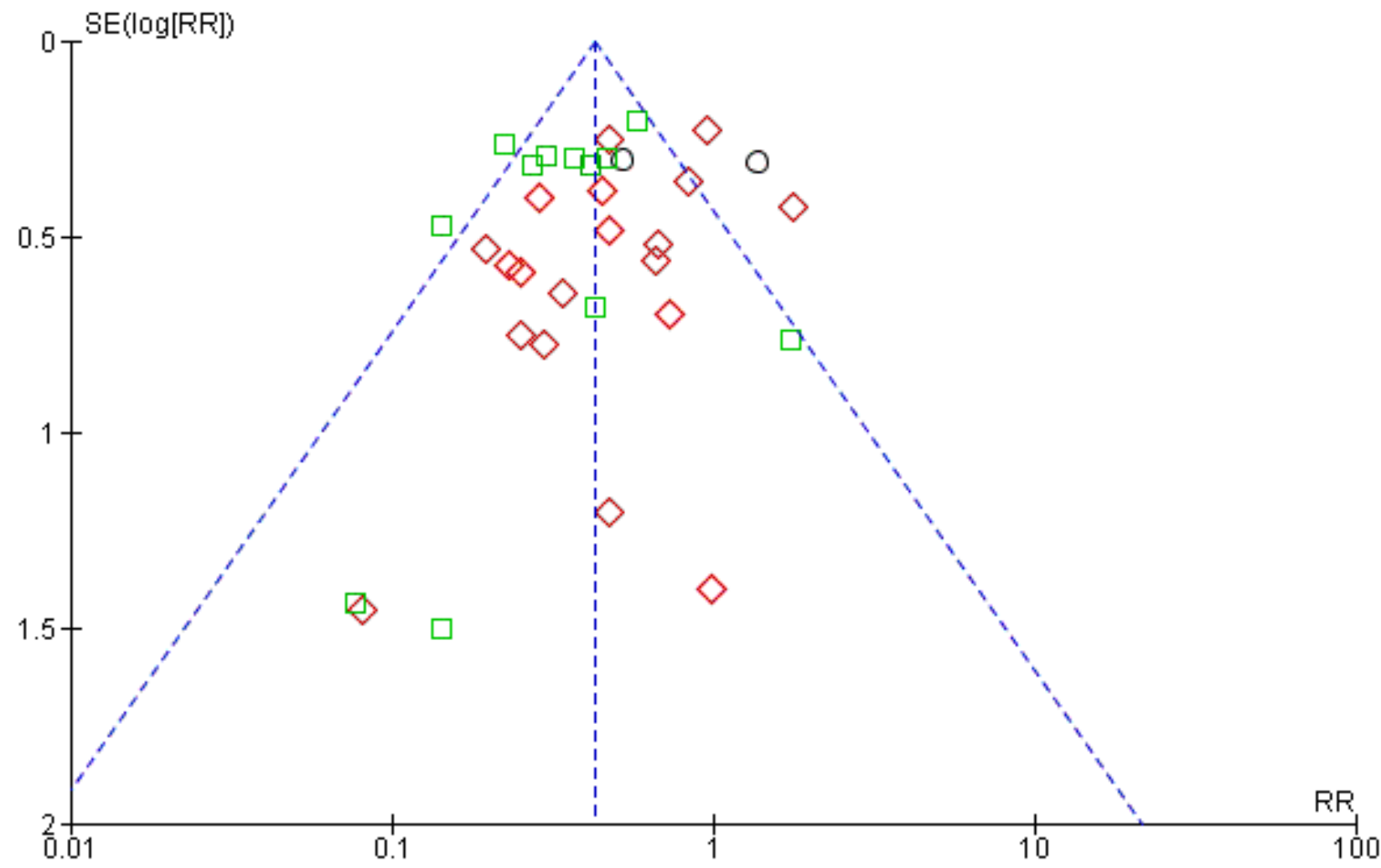

Subgroups

Active controlled

Placebo controlled

No treatment control 
Figure 5. Funnel plot of comparison: 1 Probiotics versus control, outcome: 1.1 Incidence of diarrhea: Complete case.

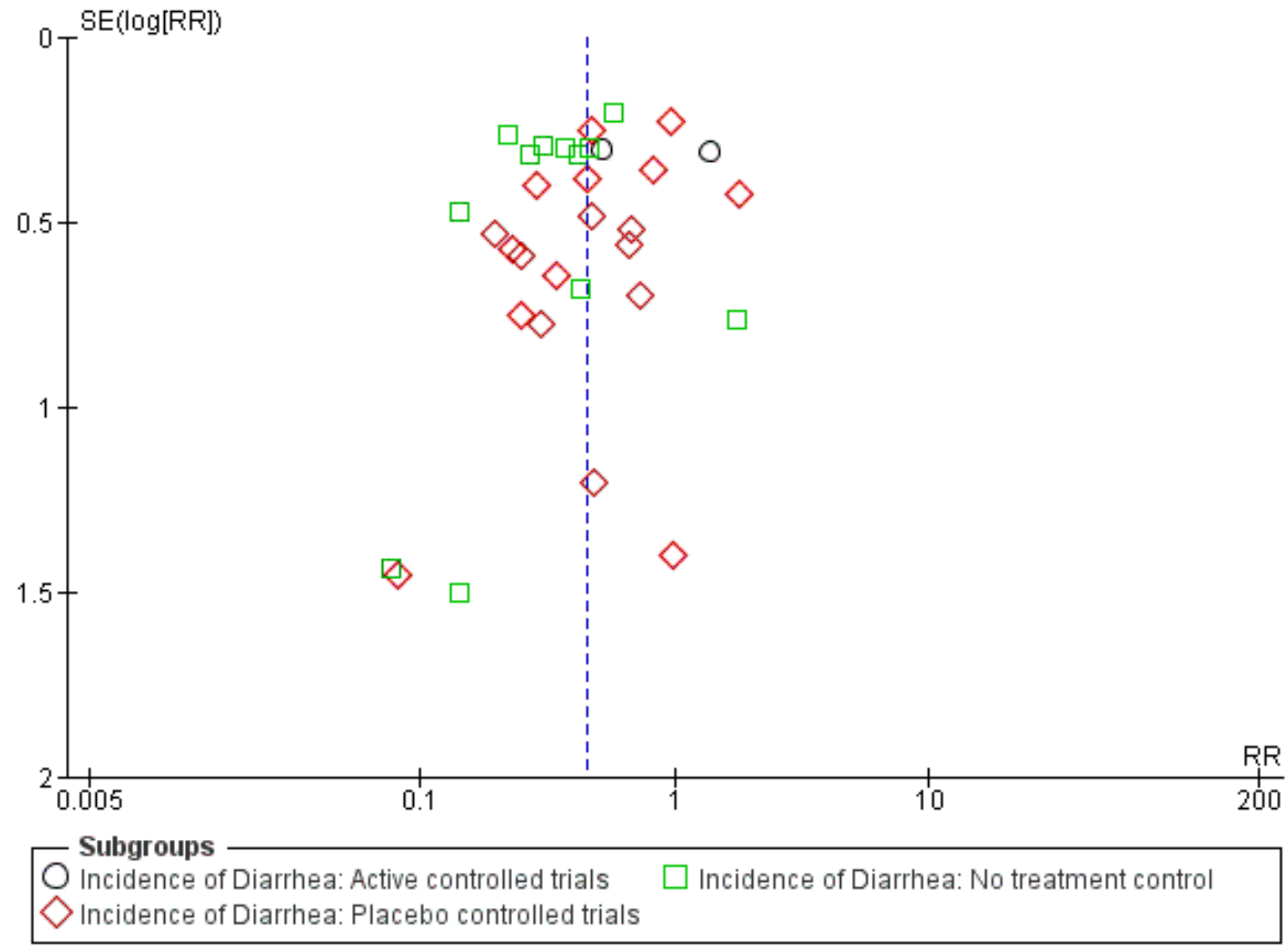

\section{DISCUSSION}

\section{Summary of main results}

The primary objective of this review was to determine if the coadministration of probiotics with antibiotics prevents the incidence of antibiotic-associated diarrhea in children. Thirty-three eligible studies included treatment with Bacillus spp., Bifidobacterium spp., Clostridium butyricum, Lactobacilli spp., Lactococcus spp., Leuconostoc cremoris, Saccharomyces spp., or Streptococcus spp., alone or in combination. Fifteen of 33 trials tested S. boulardii or Lactobacillus rhamnosus spp. Complete case analysis (i.e. patients who did not complete the studies were not included in the analysis) results from 33 trials reporting on the incidence of diarrhea, demonstrated a precise benefit with an incidence of AAD of $8 \%$ (259/3232) in the probiotic group compared to $19 \%(598 / 3120)$ in the control group (RR $0.45,95 \% \mathrm{Cl} 0.36$ to $0.56, \mathrm{P}<0.00001, \mathrm{I}^{2}=57 \%$; Figure 6). The NNTB to prevent one case of diarrhea is nine (NNTB 9; $95 \% \mathrm{Cl} 7$ to 13 ), a moderate treatment effect. 
Figure 6. Forest plot of comparison: 1 Probiotics versus control, outcome: 1.1 Incidence of diarrhea: Complete case.

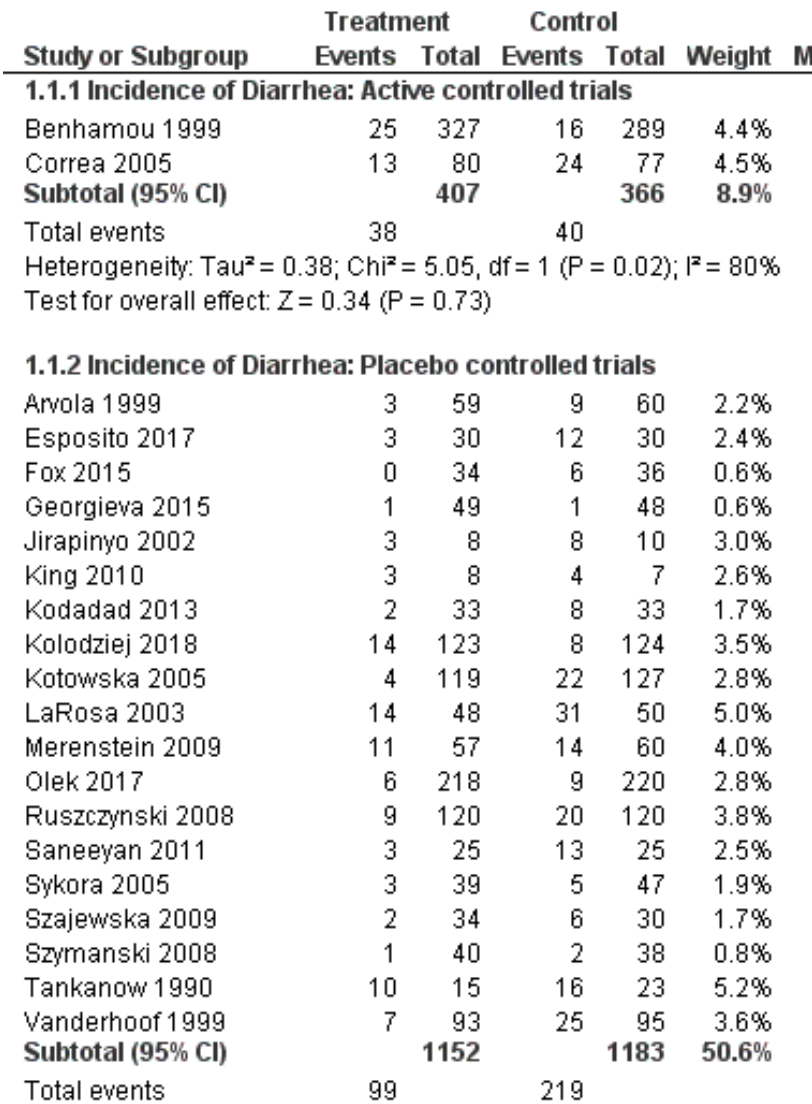

Risk Ratio

Risk Ratio

1.1.1 Incidence of Diarrhea: Active controlled trials

$1.38[0.75,2.53]$
$0.52[0.29,0.95]$

$0.52[0.29,0.95]$
$\mathbf{0 . 8 5}[0.33,2.21]$

$0.85[0.33,2.21]$

1.1.2 Incidence of Diarrhea: Placebo controlled trials

$0.34[0.10,1.19]$

$0.25[0.08,0.80]$

$0.08[0.00,1.39]$

$0.98[0.06,15.22]$

$0.47[0.18,1.21]$

$0.66[0.22,1.97]$

$0.25[0.06,1.09]$

$1.76[0.77,4.05]$

$0.19[0.07,0.55]$

$0.47[0.29,0.77]$

$0.83[0.41,1.67]$

$0.67[0.24,1.86]$

$0.45[0.21,0.95]$

$0.23[0.07,0.71]$

$0.72[0.18,2.84]$

$0.29[0.06,1.35]$

$0.47[0.04,5.03]$

$0.96[0.61,1.50]$

$0.29[0.13,0.63]$

$0.50[0.37,0.67]$

Heterogeneity: $\operatorname{Tau}^{2}=0.18 ; \mathrm{Chi}^{2}=32.50, \mathrm{df}=18(\mathrm{P}=0.02) ; \mathrm{I}^{2}=45 \%$

Test for overall effect: $Z=4.48(P<0.00001)$

$\begin{array}{lrrrrr}\text { 1.1.3 Incidence of Diarrhea: No treatment control } \\ \text { Conway 2007 } & 8 & 74 & 2 & 32 & 1.7 \% \\ \text { Destura unpublished } & 3 & 162 & 7 & 161 & 2.0 \% \\ \text { Dharani 2017 } & 0 & 50 & 3 & 50 & 0.5 \% \\ \text { Erdeve 2004 } & 14 & 244 & 42 & 222 & 4.6 \% \\ \text { Jindal 2017 } & 16 & 300 & 72 & 300 & 4.8 \% \\ \text { Peng 2014 } & 11 & 56 & 30 & 56 & 4.5 \% \\ \text { Shan 2013 } & 11 & 139 & 42 & 144 & 4.4 \% \\ \text { Wan 2017 } & 5 & 213 & 32 & 195 & 3.1 \% \\ \text { Zakordonets 2016 } & 0 & 20 & 6 & 20 & 0.6 \% \\ \text { Zhang 2015 } & 12 & 102 & 26 & 92 & 4.3 \% \\ \text { Zhao 2014 } & 27 & 120 & 47 & 120 & 5.4 \% \\ \text { Zheng 2012 } & 15 & 193 & 30 & 179 & 4.5 \% \\ \text { Subtotal (95\% CI) } & & \mathbf{1 6 7 3} & & \mathbf{1 5 7 1} & \mathbf{4 0 . 5 \%} \\ \text { Total events } & 122 & & 339 & & \end{array}$

$1.73[0.39,7.70]$

$0.43[0.11,1.62]$

$0.14[0.01,2.70]$

$0.30[0.17,0.54]$

$0.22[0.13,0.37]$

$0.37[0.20,0.66]$

$0.27[0.15,0.51]$

$0.14[0.06,0.36]$

$0.08[0.00,1.28]$

$0.42[0.22,0.78]$

$0.57[0.39,0.86]$

$0.46[0.26,0.83]$

$0.35[0.26,0.47]$ M-H, Random, $95 \%$ Cl

Heterogeneity: $\operatorname{Tau}^{2}=0.11 ; \mathrm{Chi}^{2}=20.83, \mathrm{df}=11(\mathrm{P}=0.04) ; \mathrm{I}^{2}=47 \%$

Test for overall effect: $Z=6.90$ ( $\mathrm{P}=0.00001)$

\footnotetext{
Total $(95 \% \mathrm{Cl})$

3232

Total events 259

$3120 \quad 100.0 \%$

Heterogeneity: $\operatorname{Tau}^{2}=0.21 ; \mathrm{Chi}^{2}=74.32, \mathrm{df}=32(\mathrm{P}=0.0001) ;\left.\right|^{2}=57 \%$

Test for overall effect: $Z=6.89$ ( $P=0.00001$ )

Test for subqroup differences: $\mathrm{Ch}^{2}=4.55, \mathrm{df}=2(\mathrm{P}=0.10), \mathrm{I}^{2}=56.1 \%$
}

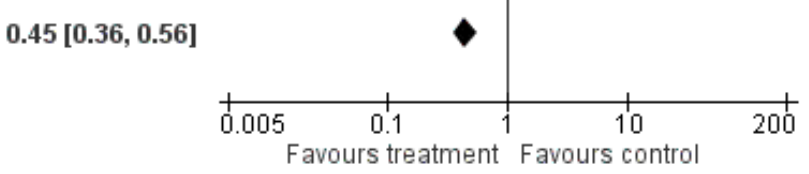

To test the robustness of our complete case analysis, we elected to make assumptions about the missing outcome data which were extreme but arguably plausible. Nineteen of 33 trials had loss to follow-up ranging from $1.2 \%$ to $46.4 \%$. After imputing data for the missing responses, an extreme-plausible analysis (60\% of children loss to follow-up in probiotic group and $20 \%$ loss to follow-up in

the control group had diarrhea) still indicated a probable benefit for probiotics (7019 participants, RR $0.61,95 \% \mathrm{Cl} 0.49$ to $0.77, \mathrm{P}<$ $\left.0.0001 ; 1^{2}=70 \%\right)$.

Statistical heterogeneity was moderate. We specified nine a priori subgroup hypotheses to explore the heterogeneity in our results, 
including inpatient versus outpatient, diagnosis type, probiotic species or strain, single versus multi strain, probiotic dose, definition of diarrhea, strictness of definition (mild versus moderate severity), industry sponsorship, and risk of bias (e.g. allocation concealment, blinding). We also conducted a post hoc subgroup analysis which included age ( $\leq 24$ months versus $>24$ months). A test for heterogeneity was significant for one subgroup: probiotic dose, providing evidence that a dose-response gradient is the most likely explanation for the statistical heterogeneity. The test for interaction for potential dose-associated heterogeneity was statistically significant $(P=0.01)$. Using 5 criteria to evaluate the credibility of the subgroup analysis, the results indicate that the subgroup effect based on dose ( $\geq 5$ billion CFUs per day) was convincing (Sun 2014); see Appendix 2). This represents an important finding as dosage recommendations for products containing probiotics available in pharmacies and health food stores have a wide range (e.g. 0.2 billion to 2 trillion CFUs per day). Dosages approaching the lower range may not confer a benefit (Ouwehand 2017; Raza 1995), while doses in the upper range may be associated with an increased risk of adverse events. Given our review included trials testing 19 different probiotics (single or multi-agent species), amongst a diverse clinical population, with nearly all demonstrating favourable results; for the purposes of clinical use and future research, our findings suggest that the minimal effective dose may be 5 billion CFUs per day, with an upper range of 40 billion CFUs/day considered efficacious in otherwise healthy children (RR $0.37,95 \% \mathrm{Cl} 0.30$ to 0.46 ; NNTB $6,95 \% \mathrm{Cl} 5$ to 9 ). Further, although we did not observe a statistically significant effect based on our post-hoc subgroup on age, evidence from the largest cohort study we are aware of assessing the risk for AAD among 650 outpatient children in France suggests a six-fold increased risk of $A A D$ in children $\leq 2$ years of age $(18 \%$ risk of $A A D)$ versus children $>2$ years (3\% risk of AAD) of age (Turck 2003). Based on the RR from trials administering $\geq 5$ billion CFUs/day, for children $\leq 2$ years of age the absolute risk reduction is 113 fewer AAD cases per 1000 children followed (95\% Cl 97 to 126 fewer cases), while for children $>2$ years of age the absolute risk reduction is 19 fewer AAD cases per 1000 children followed ( $95 \% \mathrm{Cl} 16$ to 21 fewer cases). These results, although post-hoc, suggest that probiotics are substantially more effective in younger children.

Regarding safety, 24/33 trials reported on adverse events, none having reported a serious adverse event. Meta-analysis demonstrated no substantial differences in the incidence of any adverse events between treatment and control (RD 0.00, 95\% Cl -0.01 to $\left.0.01, \mathrm{P}<0.59 ;\left.\right|^{2}=75 \%\right)$.

\section{Overall completeness and applicability of evidence}

We included 33 trials of children $(n=6352)$, both male and female aged from 3 days to 18 years ( 6 studies in those $\leq 2$ years, 26 studies in those $>2$ years) from diverse socioeconomic status across 17 countries including both developed country and developing countries. We believe the population is varied enough for results to be generalized to healthy children receiving antibiotics. However, only one study included newborns and one study with just 15 participants was conducted in the Intensive Care Unit (ICU), thus the applicability of our results to newborns and ICU children is unknown.

Studies used 19 different probiotic interventions including different species and/or strain(s), as well as dosages versus placebo (19 studies), no probiotics (12 studies) and active control (2 studies). We did subgroup analysis to explore the different interventions, both species and strain and the results demonstrated no difference in the prevention of $A A D$, suggesting enhanced generalizability of our findings. For the dosage of probiotics, a test for interaction revealed that the subgroup effect based on high dose ( $\geq 5$ billion CFUs/ day) probiotics was superior to low dose, suggesting that high dose interventions of various probiotics are most likely to be beneficial (particularly Lactobacillus GG and Saccharomyces boulardii, the most studied products).

The outcome, incidence of $A A D$, was reported in all included studies, while 24 studies $(n=4415)$ reported on the potential for adverse events. However, our findings are not representative of all available data on adverse events as we only included randomized trials, whereas observational studies may suggest the potential for harm in some pediatric populations. With respect to secondary outcomes, only 9 studies reported on duration of diarrhea $(n=1263)$ and one study reported the microbiome characteristics. Although the results of microbiome characteristics are generally unaddressed and may be helpful to understanding the probiotic mechanism of action, we believe the data on AAD and adverse event outcomes directly answer the question that clinicians and researchers have.

\section{Quality of the evidence}

Using the Cochrane risk of bias tool, we rated 13 trials as low risk of bias (Destura unpublished; Fox 2015; Georgieva 2015; Kodadad 2013; Kolodziej 2018; Kotowska 2005; LaRosa 2003; Merenstein 2009; Olek 2017; Ruszczynski 2008; Sykora 2005; Szajewska 2009; Szymanski 2008). Twenty trials were rated as high risk of bias (Arvola 1999; Benhamou 1999; Conway 2007; Correa 2005; Dharani 2017; Erdeve 2004; Esposito 2017; Jindal 2017; Jirapinyo 2002; King 2010; Peng 2014; Saneeyan 2011; Shan 2013; Tankanow 1990; Vanderhoof 1999; Wan 2017; Zakordonets 2016; Zhang 2015; Zhao 2014; Zheng 2012). The most common reasons for a high risk of bias rating were lack of blinding and incomplete outcome data.

The certainty of evidence supporting each outcome was determined using the GRADE criteria (Guyatt 2008). For the main efficacy outcome, incidence of diarrhea, the certainty of the evidence was rated as moderate (the true effect is likely to be close to the estimate of the effect, but there is a possibility that it is substantially different) because of the minor issues with risk of bias related to poor reporting regarding allocation concealment, blinding and incomplete data, as well as inconsistency related to the diversity of probiotics used. For the incidence of adverse events the certainty of the evidence was rated as low (we have very little confidence in the effect estimate: The true effect is likely to be substantially different from the effect estimate). However, probiotics were generally well tolerated and no serious adverse events attributable to probiotics were reported and we feel confident that the absolute effect, if it exists, is small.

Concerning the secondary outcome mean duration of diarrhea (eight trials, $n=1263$ ), using a complete case analysis, probiotics decreased the mean duration of diarrhea by almost one day (MD $-0.91 ; 95 \% \mathrm{Cl}-1.38$ to -0.44$)$, representing a moderate treatment effect. The certainty of the evidence was rated as low owing to inconsistency (i.e. large statistical heterogeneity with $\mathrm{I}^{2}$ of $>$ $77 \%$, low $P$ value $[P<0.06]$, point estimates and confidence intervals varied considerably) and imprecision (e.g. confidence intervals include effect estimates that are of questionable patient 
importance). Furthermore, results for mean duration of diarrhea may be misleading given our suspicion of selective reporting bias. In particular, the majority of studies fail to report results for this key outcome that otherwise would be expected to have been evaluated. A previous systematic review of the methods used in RCTs evaluating acute diarrhea reported that duration of diarrhea was the most common primary outcome $(72 / 138$ trials, $52 \%$ of trials) and this was reported in almost all trials as either a primary or secondary outcome (Johnston 2010). In this review, only 8 of 33 trials assessing probiotics for the prevention of pediatric $A A D$ reported on duration of diarrhea as a primary or secondary outcome.

With respect to microbiome characteristics, only one study reported such an analysis. Zakordonets 2016 used five probiotic species including Lactobacilli, Lactococci, Bifidobacterium (strain not specified) versus no treatment (antibiotic only) and reported on fecal microflora composition changes in microbiome at baseline, one day after discontinuation of antibiotic, and one month after discontinuation of antibiotic. The authors reported slight differences between the probiotic and the antibiotic only group with respect to total E. coli, lactose (-) and hemolytic E. coli, and Staphylloccus aureas at one day after discontinuation of antibiotic $(P<0.05)$. At one month, Zakordonets 2016 also reported slight differences in lactose (-) and Hemolytic E. coli, Staphylloccus aureas, Candida spp and Klebsiella pneumoniae $(\mathrm{P}<0.05)$. There were no changes in Lactobacillus spp or Bifidobacterium spp $(\mathrm{P}<0.05)$. No studies reported on $16 \mathrm{~S}$ rRNA or other microbiome analyses. GRADE analysis indicated that overall quality of evidence for this outcome was very low due to selective reporting, imprecision, and indirectness (outcome not of importance to patients).

\section{Potential biases in the review process}

This systematic review has several strengths. We asked a clear and relevant clinical question and the search strategy for this review was comprehensive including all relevant trials irrespective of language or publication status (i.e. we included unpublished data from Destura unpublished and abstract data from King 2010; and we obtained pediatric specific data from Conway 2007). Additional strengths of the review include the independent application of the GRADE criteria to assess the certainty of evidence for each of the outcomes (Guyatt 2008), and the rigorous evaluation of nine a priori subgroups (e.g. inpatient versus outpatient, diagnosis type, probiotic species, single versus multi strain, probiotic dose, definition of diarrhea, strictness of definition (mild versus moderate), industry sponsorship, and risk of bias) using the five criteria for assessing subgroup credibility (Sun 2014).

This review also has some limitations. First, although we previously did a more comprehensive search of the grey literature, for our update search we did not search conference proceedings or dissertation abstracts. Second, some readers may question the pooling of different probiotic species. In keeping with the justification for the combining of probiotic species used in two trials included in this review (Tankanow 1990 administered both L. acidophilus with L. bulgaricus; Jirapinyo 2002 administered both L. acidophilus with B. infantis; Szymanski 2008 administered a cocktail of $B$. longum, $L$. rhamnosus and $L$. plantarum), data were pooled because the probiotics used in each trial share the recommended characteristics of a viable probiotic: non-pathogenic properties (noting that further study is needed on L. sporogenes), the ability to survive transit through the gastrointestinal tract, adherence to intestinal epithelium, colonization in the intestinal tract, production of antimicrobial substances, and a good shelf life in food or powdered form (Goldin 1998). To assess differences that may exist between species and strains, we conducted a priori subgroup analyses and found no statistically significant differences between species or strains. Third, only one study assessed changes in microbiome characteristics before and after antibiotic and probiotic administration demonstrating no important differences. However, our findings are not representative of all available data on the topic as we only included randomized trials that assessed AAD as an outcome. For instance, a recent non-randomized controlled trial examined the potential effects of an 11 strain probiotic versus fecal transplantation versus no treatment on the microbiome after broad-spectrum antibiotic use in 21 healthy adults (Suez 2018). Probiotics were associated with a delay in transcriptome reconstitution of indigenous stool and mucosal microbiome configuration, while transplantation was associated with a quick and complete recovery after just a few days. Although Suez 2018 did not examine concurrent use of probiotics with antibiotics, nor did they examine children, their findings raise questions about the use of probiotics after antibiotic use. Unfortunately, there are many examples of early findings from laboratory experiments such as this with apparent harmful or salutary physiological effects, yet with subsequent clinical studies there is no apparent affect when assessing more patient-important outcomes (Ferreira 2007). Hence, focusing on the findings from Suez 2018 can only provide indirect low quality evidence for clinical outcomes of importance to patients such as diarrhea or quality of life (Johnston 2013).

Finally, our findings are based on an aggregate data meta-analysis and this does not allow us to fully explore participants (e.g. sex) and intervention level variables (e.g. number of antibiotics prescribed) that may be associated with AAD. To explore this issue in metaanalysis, one would require individual patient data which we do not currently have access to.

\section{Agreements and disagreements with other studies or reviews}

At least thirteen systematic reviews and meta-analyses have addressed the use of probiotics, alone or in combination, for the prevention of $A A D$ in adults and children. The results of diverse probiotic agents co-administered with antibiotics favoured probiotics (RR 0.43; $95 \% \mathrm{Cl} 0.31$ to 0.58 ; McFarland 2006; RR 0.48; $95 \%$ Cl 0.35 to 0.65; Sazawal 2006; RR 0.40; $95 \%$ Cl 0.28 to 0.57; Cremonini 2002 and OR 0.37; 95\% Cl 0.26 to 0.53; D'Souza 2002). Additionally, meta-analyses addressing the use of a single probiotic agent to prevent AAD examining Saccharomyces boulardii (S. boulardii) and Lactobacillus have also favoured probiotic treatment (RR 0.35, 95\% Cl 0.19 to 0.67; Kale-Pradhan 2010; RR 0.47, 95\% Cl: 0.35 to 0.63 ; McFarland 2010; and RR 0.43 ; $95 \%$ Cl: 0.23 to 0.78 ; Szajewska 2005). Six meta-analyses of randomized trials evaluating the efficacy of probiotics for preventing antibiotic-induced diarrhea in children have also suggested benefit (RR $0.43 ; 95 \% \mathrm{Cl} 0.25$ to 0.75; Johnston 2006; RR 0.52, 95\% Cl 0.38 to 0.72; Johnston 2011; RR 0.46; $95 \% \mathrm{Cl} 0.35$ to 0.61 ; Goldenberg 2015; RR 0.43; $95 \% \mathrm{Cl} 0.33$ to 0.56 ; McFarland 2015; RR 0.44; $95 \% \mathrm{Cl} 0.25$ to 0.77 ; Szajewska 2006; RR 0.48; $95 \%$ Cl 0.26 to 0.89 ; Szajewska 2015). This systematic review is an update of a previously published Cochrane review (Johnston 2007; Johnston 2011; Goldenberg 2015). This updated Cochrane review identified an additional 11 trials reporting on $A A D$, thus increasing the precision of our earlier results. 


\section{AUTHORS' CONCLUSIONS}

\section{Implications for practice}

Moderate quality evidence suggests a protective effect of probiotics in preventing AAD. A test for heterogeneity indicates that a doseresponse gradient explains the observed statistical heterogeneity. Using five criteria to evaluate the credibility of the subgroup analysis on probiotic dose, complete case results indicate that the subgroup effect based on dose ( $\geq 5$ billion CFUs per day) was credible, demonstrating a large, precise benefit of high dose probiotics (RR 0.37; 95\% Cl 0.30, 0.46; $\mathrm{P}=0.06 ; \mathrm{I}^{2}=36 \%$ ). Based on high-dose probiotics, the NNTB to prevent one case of diarrhea is six (NNTB 6; 95\% Cl 5 to 9). The likelihood of serious adverse events is very rare. The bulk of evidence exists for Lactobacillus $G G$ and Saccharomyces boulardii. It is premature to draw conclusions about the efficacy and safety of 'other' probiotic agents for pediatric AAD. Although no serious adverse events were observed among mostly healthy children (noting that we included two small trials of children in the intensive care and neonatal unit), serious adverse events have been observed, mostly from case reports, in severely debilitated or immuno-compromised children with underlying risk factors including central venous catheter use and disorders associated with bacterial/fungal translocation.

\section{Implications for research}

The overall quality of the evidence for the primary endpoint of incidence of diarrhea was moderate. We rated the quality of evidence down due to minor issues with risk of bias and inconsistency (19 probiotic products used among 33 trials). Large trials are needed to better evaluate single or multiple strain specific probiotics among: 1) outpatients on oral antibiotics, 2) inpatients on intravenous antibiotics and 3) immune-compromised patients. In addition to assessing probiotics for the prevention of AAD, these trials should better assess the safety of probiotics and the potential impact of probiotics on the duration of diarrhea. In assessing safety, trials should define potential adverse events a priori and monitor for these adverse reactions according to available guidelines (Bafeta 2018; loannidis 2004).

\section{A C K N O WLEDGEMENTS}

We would like to thank John K MacDonald (Cochrane IBD Review Group) for his excellent ongoing support and our colleagues (Guoguang Xiao) that verified our data extraction of the Chinese studies. We also wish to thank Leah Boulos at the Martime SPOR Support Unit for revising the search strategy and running the updated search.

Funding for the Cochrane IBD Group (May 1, 2017 - April 30, 2022) has been provided by Crohn's and Colitis Canada (CCC). 


\section{RE F E R E N C E S}

\section{References to studies included in this review}

Arvola 1999 \{published data only\}

Arvola T, Laiho K, Torkkeli S, Mykkanen H, Salminen S, Maunula L, et al. Prophylactic Lactobacillus GG reduces antibiotic-associated diarrhea in children with respiratory infections: a randomized study. Pediatrics 1999;104(5):e64.

\section{Benhamou 1999 \{published data only\}}

Benhamou PH, Berlier P, Danjou G, Plique O, Jessueld D, DuPont C. Antibiotic-associated diarrhoea in children: A computer monitored double-blind outpatients trial comparing a protective and a probiotic agent. Médecine \& Chirurgie Digestives 1999;28(4):163-8.

\section{Conway 2007 \{published data only\}}

Conway S, Hart A, Clark A, Harvey I. Does eating yogurt prevent antibiotic-associated diarrhoea? A placebo-controlled randomised controlled trial in general practice. British Journal of General Practice 2007;57(545):953-9.

\section{Correa 2005 \{published data only\}}

Corrêa NB, Péret Filho LA, Penna FJ, Lima FM, Nicoli JR. A randomized formula controlled trial of Bifidobacterium lactis and Streptococcus thermophilus for prevention of antibiotic-associated diarrhea in infants. Journal of Clinical Gastroenterology 2005;39(5):385-9.

\section{Destura unpublished \{published data only\}}

Destura RV. Bacillus clausii in preventing antibiotic-associated diarrhea among Filipino infants and children: A multi-center, randomized, open-label clinical trial of efficacy and safety. unpublished.

\section{Dharani 2017 \{published and unpublished data\}}

Dharnai S, Nirmala P, Ramanathan R, Vanitha S. Comparative study of efficacy and safety of azithromycin alone and in combination with probiotic in the treatment of impetigo in children. International Journal of Current Pharmaceutical Research 2017;9(6):52-5.

\section{Erdeve 2004 \{published data only\}}

Erdeve O, Tiras U, Dallar Y. The probiotic effect of Saccharomyces boulardii in a pediatric age group. Journal of Tropical Pediatrics 2004;50(4):234-6.

\section{Esposito 2017 \{published and unpublished data\}}

Esposito C, Roberti A, Turrà F, Cerulo M, Severino G, Settimi A, et al. Frequency of antibiotic-associated diarrhea and related complications in pediatric patients who underwent hypospadias repair: a comparative study using probiotics vs placebo. Probiotics Antimicrob Proteins 2018;10:323-8.

\section{Fox 2015 \{published data only\}}

Fox M, Ahuja K, Robertson I, Ball M, Eri R. Can probiotic yogurt prevent diarrhoea in children on antibiotics? A double blind, randomised, placebo-controlled study. BMJ Open 2015;5:e006474.
Georgieva 2015 \{published and unpublished data\}

* Georgieva M, Pancheva R, Rasheva N, Usheva N, Ivanova L, Koleva K. Use of the probiotic Lactobacillus reuteri DSM 17938 in the prevention of antibiotic-associated infections in hospitalized Bulgarian children: a randomized, controlled trial. Journal of IMAB 2015;21(4):895-900.

\section{Jindal 2017 \{published and unpublished data\}}

Jindal M, Goyal Y, lata S, Sharma R K. Preventive role of probiotic in antibiotic associated diarrhoea in children. Indian Journal of Public Health Research and Development 2017;3:66-9.

\section{Jirapinyo 2002 \{published data only\}}

Jirapinyo P, Densupsoontorn N, Thamonsiri N, Wongarn R. Prevention of antibiotic-associated diarrhea in infants by probiotics. Journal of the Medical Association of Thailand 2002;85 Suppl 2:s739-42.

\section{King 2010 \{unpublished data only\}}

King S, Walton S, Chung A, Vidal R, Falkos S, Bonafante E. A randomized, double-blind, placebo controlled trial to assess the efficacy of Lactobacillus $G G$ in the prevention of antibioticassociated diarrhea in the pediatric intensive care unit. Unpublished. (Published conference abstract and email with authors).

\section{Kodadad 2013 \{published data only\}}

Ahmad K, Fatemeh F, Mehri N, Maryam S. Probiotics for the Treatment of Pediatric Helicobacter Pylori Infection:A Randomized Double Blind Clinical Trial. Iranian Journal of Pediatrics 2013;23(1):79-84.

\section{Kolodziej 2018 \{published data only\}}

Kołodziej M, Szajewska H. Lactobacillus reuteri DSM 17938 in the prevention of antibiotic-associated diarrhea in children: a randomized clinical trial. Clinical Microbiology and Infection 2018 Aug 24 [Epub ahead of print]. [DOI: 10.1016/ j.cmi.2018.08.017]

\section{Kotowska 2005 \{published data only\}}

Kotowska M, Albrecht P, Szajewska H. Saccharomyces boulardii in the prevention of antibiotic-associated diarrhoea in children: a randomized double-blind placebo-controlled trial. Alimentary Pharmacology and Therapeutics 2005;21(5):583-90.

\section{LaRosa 2003 \{published data only\}}

LaRosa M, Bottaro G, Gulino N, Gambuzza F, Di Forti F, Ini G, et al. Prevention of antibiotic-associated diarrhea with Lactobacillus sporogens and fructo-oligosaccharides in children: A multicentric double-blind vs placebo study. Minerva Pediatrica 2003;55(5):447-52.

\section{Merenstein 2009 \{published data only\}}

Merenstein DJ, Foster J, D'Amico F. A randomized clinical trial measuring the influence of kefir on antibiotic-associated diarrhea: the measuring the influence of Kefir (MILK) Study. Archives of Pediatrics \& Adolescent Medicine 2009;163(8):750-4. 
Olek 2017 \{published and unpublished data\}

Olek A, Woynarowski M, Ahrén IL, Kierkuś J, Socha P, Larsson N, Önning G. Efficacy and Safety of Lactobacillus plantarum DSM 9843 (LP299V) in the Prevention of Antibiotic-Associated Gastrointestinal Symptoms in Children-Randomized, Double-Blind, Placebo-Controlled Study. Journal of Pediatrics 2017;186:82-6.

\section{Peng 2014 \{published and unpublished data\}}

Peng F, Wu S Y. Oral Saccharomyces boulardii combined with conventional antibiotic therapy for treatment of secondary diarrhea in neonates [口服布拉酵母菌联合常规抗生素治疗对 新生儿患者继发腹泻的治疗作用]. Shijie Huaren Xiaohua Zazhi 2014;22(28):4364-7.

\section{Ruszczynski 2008 \{published data only\}}

Ruszczyński M, Radzikowski A, Szajewska H. Clinical trial: effectiveness of Lactobacillus rhamnosus (strains $\mathrm{E} / \mathrm{N}$, Oxy and Pen) in the prevention of antibiotic-associated diarrhoea in children. Alimentary Pharmacology and Therapeutics 2008;28(1):154-61.

\section{Saneeyan 2011 \{published data only\}}

Saneeyan H, Layegh S, Rahimi H. Effectivness of probiotic on treatment of Helicobacter pylori infection in children. Journal of Isfahan Medical School 2011;29(146):882-9.

\section{Shan 2013 \{published data only\}}

Shan L, Hou Z, Wang F, Liu N, Chen L, Shu H, et al. Prevention and treatment of diarrhoea with Saccharomyces boulardii in children with acute lower respiratory tract infections. Beneficial Microbes 2013;4(4):329-34.

\section{Sykora 2005 \{published data only\}}

Sykora J, Valeckova K, Amlerova J, Siala K, Dedek P, Watkins S, et al. Effects of a specially designed fermented milk product containing probiotic Lactobacillus casei DN-114 001 and the eradication of $\mathrm{H}$. pylori in children: a prospective randomized double-blind study. Journal of Clinical Gastroenterology 2005;39(8):692-8.

\section{Szajewska 2009 \{published data only\}}

Szajewska H, Albrecht P, Topczewska-Cabanek A. Randomized, double-blind, placebo-controlled trial: effect of Lactobacillus $G G$ supplementation on Helicobacter pylori eradication rates and side effects during treatment in children. Journal of Pediatric Gastroenterology and Nutrition 2009;48(4):431-6.

\section{Szymanski 2008 \{published data only\}}

Szymański H, Armańska M, Kowalska-Duplaga K, Szajewska H. Bifidobacterium longum PL03, Lactobacillus rhamnosus $\mathrm{KL} 53 \mathrm{~A}$, and Lactobacillus plantarum PL02 in the prevention of antibiotic-associated diarrhea in children: a randomized controlled pilot trial. Digestion 2008;78(1):13-7.

\section{Tankanow 1990 \{published data only\}}

Tankanow RM, Ross MB, Ertel IJ, Dickinson DG, McCormick LS, Garfinkel JF. A double-blind, placebo-controlled study of the efficacy of Lactinex in the prophylaxis of amoxicillininduced diarrhea. DICP: The Annals of Pharmacotherapy 1990;24(4):382-4.
Vanderhoof 1999 \{published data only\}

Vanderhoof JA, Whitney DB, Antonson DL, Hanner TL, Lupo JV, Young RJ. Lactobacillus GG in the prevention of antibiotic-associated diarrhea in children. Journal of Pediatrics 1999;135(5):564-8.

\section{Wan 2017 \{published and unpublished data\}}

Wan CM, Yu H, Liu G, Xu HM, Mao ZQ, Xu Y, et al. A multicenter randomized controlled study of Saccharomyces boulardii in the prevention of antibiotic-associated diarrhea in infants and young children [布拉酵母菌预防婴幼儿抗生素相关 性腹泻的多中心随机对照研究]. Zhonghua Er Ke Za Zhi 2017;55(5):349-54.

\section{Zakordonets 2016 \{published and unpublished data\}}

Zakordonets L, Tolstanova G, Yankovskiy D, Dyment $\mathrm{H}$, Kramarev S. Different regimes of multiprobiotic for prevention of immediate and delayed side effects of antibiotic therapy In children. Research Journal of Pharmaceutical, Biological and Chemical Sciences 2016;7(3):2194-201.

\section{Zhang 2015 \{published and unpublished data\}}

Zhang B, Xu Y Zh, Deng Zh H, Chu B, Jiang LR, Vandenplas Y. The efficacy of Saccharomyces boulardii CNCM I-745 in addition to standard Helicobacter pylori eradication treatment in children. Journal of Pediatric Gastroenterology and Nutrition 2015;18(1):17-22.

\section{Zhao 2014 \{published data only\}}

Zhao HM, Ou-Yang HJ, Duan BP, Xu B, Chen ZY, Tang J, et al. Clinical effect of triple therapy combined with Saccharomyces boulardii in the treatment of Helicobacter pylori infection in children. Zhongguo Dang Dai Er Ke Za Zhi 2014;16(3):230-3.

\section{Zheng 2012 \{published data only\}}

Zheng YJ, Mao ZQ, Wu QB, Liu CY, Huang ZH, Huang YK, et al. Multicenter, randomized, controlled clinical trial on preventing antibiotic-associated diarrhea in children with pneumonia using the live Clostridium butyricum and Bifidobacterium combined powder. Chinese Journal of Pediatrics 2012;50:732-6.

\section{References to studies excluded from this review}

\section{Adam 1977 \{published data only\}}

Adam J, Barret A, Barret-Bellet C. [Essais cliniques controles en double insu de l'ultra-levure lyphilisee: etude multicentrique par 25 medicins de 388 cas]. Gazette Médicale de France 1977;84:2072-8.

\section{Beausoleil 2007 \{published data only\}}

Beausoleil M, Fortier N, Guénette S, L'ecuyer A, Savoie M, Franco $M$, et al. Effect of a fermented milk combining Lactobacillus acidophilus Cl1285 and Lactobacillus casei in the prevention of antibiotic-associated diarrhea: a randomized, double-blind, placebo-controlled trial. Canadian Journal of Gastroenterology 2007;21(11):732-6.

\section{Brunser 2006 \{published data only\}}

Brunser O, Gotteland M, Cruchet S, Figueroa G, Garrido D, Steenhout P. Effect of a milk formula with prebiotics on the 
intestinal microbiota of infants after an antibiotic treatment. Pediatric Research 2006;59(3):451-6.

Can 2006 \{published data only\}

Can M, Besirbellioglu BA, Avci IY, Beker CM, Pahsa A. Prophylactic Saccharomyces boulardii in the prevention of antibiotic-associated diarrhea: a prospective study. Medical Science Monitor 2006;12(4):PI19-22.

\section{Chapoy 1985 \{published data only\}}

Chapoy P. Treatment of acute infantile diarrhea: controlled trial of Saccharomyces boulardii [Traitement des diarrhees aigues infantiles: essai controle de Saccharomces boulardii]. Annales de Pédiatrie 1985;32(6):561-3.

\section{Contreras 1983 \{published data only\}}

Contreras G, Corti C, Cassani E. Lactobacillus acidophilus in childhood diarrhea. Compendium de Investigaciones Clínicas Latinoamericanas 1983;3:114-6.

\section{Czerwionka 2006 \{published data only\}}

Czerwionka-Szaflarska M, Kuczynska R, Mierzwa G, Bala G, Murawska S. Effect of probiotic bacteria supplementation on the tolerance of Helicobacter pylori eradication therapy in children and youth. Pediatria Polska 2006;81(5):334-41.

\section{Dajani 2013 \{published data only\}}

Dajani Al, Abu Hammour AM, Yang DH, Chung PC, Nounou MA, Yuan $\mathrm{KY}$, et al. Do probiotics improve eradication response to Helicobacter pylori on standard triple or sequential therapy?. Saudi Journal of Gastroenterology 2013;19(3):113-20.

\section{Daschner 1979 \{published data only\}}

Daschner F, Kienitz M. A Saccharomyces preparation for diarrhea? [Perenterol bei Durchfallen?]. Gynakol Prax 1979;3(3):530-1.

\section{Duman 2005 \{published data only\}}

Duman DG, Bor S, Ozütemiz O, Sahin T, Oğuz D, Iştan F, et al. Efficacy and safety of Saccharomyces boulardii in prevention of antibiotic-associated diarrhoea due to Helicobacter pylori eradication. European Journal of Gastroenterology \& Hepatology 2005;17(12):1357-61.

\section{Erdeve 2005 \{published data only\}}

Erdeve O, Tiras U, Dallar Y, Savas S. Saccaromyces boulardii and antibiotic-associated diarrhoea in children. Alimentary Pharmacology and Therapeutics 2005;21(12):1508-9.

\section{Guandalini 1988 \{published data only\}}

Guandalini S, Fasano A. Antibiotic-induced diarrhea. Rivista Italiana di Pediatria 1988;14(2):145-9.

\section{Honeycutt 2007 \{published data only\}}

Honeycutt TC, El Khashab M, Wardrop RM 3rd, McNeal-Trice K, Honeycutt AL, Christy CG, et al. Probiotic administration and the incidence of nosocomial infection in pediatric intensive care: a randomized placebo-controlled trial. Pediatric Critical Care Medicine 2007;8(5):452-8.
Hosjak 2010 \{published data only\}

Hojsak I, Abdović S, Szajewska H, Milosević M, Krznarić Z, Kolacek S. Lactobacillus GG in the prevention of nosocomial gastrointestinal and respiratory tract infections. Pediatrics 2010;125(5):e1171-7.

\section{Hurduc 2009 \{published data only\}}

Hurduc V, Plesca D, Dragomir D, Sajin M, Vandenplas Y. A randomized, open trial evaluating the effect of Saccharomyces boulardii on the eradication rate of Helicobacter pylori infection in children. Acta Paediatrica 2009;98(1):127-31.

Imase 2008 \{published data only\}

Imase K, Takahashi M, Tanaka A, Tokunaga K, Sugano H, Tanaka M, et al. Efficacy of Clostridium butyricum preparation concomitantly with Helicobacter pylori eradication therapy in relation to changes in the intestinal microbiota. Microbiology and Immunology 2008;52(3):156-61.

Islek 2015 \{published data only\}

Islek A, Sayar E, Yilmaz A, Artan R. Bifidobacterium lactis B94 plus inulin for Treatment of Helicobacter pylori infection in children: does it increase eradication rate and patient compliance?. Acta Gastroenterologica Belgica 2015;78(3):282-6.

Kim 2008 \{published data only\}

Kim MN, Kim N, Lee SH, Park YS, Hwang JH, Kim JW, et al. The effects of probiotics on PPI-triple therapy for Helicobacter pylori eradication. Helicobacter 2008;13(4):261-8.

Kleinkauf 1959 \{published data only\}

Kleinkauf I. The use of resistant acidophilus strains during antibiotic therapy [Erfahrungen mit der Anwendung resistenter Acidophilusstämme während der antibiotischen Therapie]. Archiv für Kinderheilkunde 1959;160:51-60.

Koning 2008 \{published data only\}

Koning CJ, Jonkers DM, Stobberingh EE, Mulder L, Rombouts FM, Stockbrügger RW. The effect of a multispecies probiotic on the intestinal microbiota and bowel movements in healthy volunteers taking the antibiotic amoxycillin. American Journal of Gastroenterology 2008;103(1):178-89.

\section{Lei 2006 \{published data only\}}

Lei V, Friis H, Michaelsen KF. Spontaneously fermented millet product as a natural probiotic treatment for diarrhoea in young children: an intervention study in northern Ghana. International Journal of Food Microbiology 2006;110(3):246-53.

\section{Lin 2009 \{published data only\}}

Lin JS, Chiu YH, Lin NT, Chu CH, Huang KC, Liao KW, et al. Different effects of probiotic species/strains on infections in preschool children: A double-blind, randomized,controlled study. Vaccine 2009;27(7):1073-9.

\section{Lionetti 2006 \{published data only\}}

Lionetti E, Miniello VL, Castellaneta SP, Magistá AM, de Canio A, Maurogiovanni G, et al. Lactobacillus reuteri therapy to reduce side-effects during anti-Helicobacter pylori treatment in children: a randomized placebo controlled trial. Alimentary Pharmacology and Therapeutics 2006;24(10):1461-8. 
McFarland 2005 \{published data only\}

McFarland LV. Can Saccharomyces boulardii prevent antibioticassociated diarrhea in children?. Nature Clinical Practice Gastroenterology \& Hepatology 2005;2(6):262-3.

\section{Michail 2011 \{published data only\}}

Michail S, Kenche H. Gut microbiota is not modified by Randomized, Double-blind, Placebo-controlled Trial of VSL\#3 in Diarrhea-predominant Irritable Bowel Syndrome. Probiotics Antimicrob Proteins 2011;3(1):1-7.

\section{Michielutti 1996 \{published data only\}}

Michielutti F, Bertini B, Presciuttini B, Andreotti G. Clinical assessment of a new oral bacterial treatment for children with acute diarrhea [Valutazione clinica di un nuovo batterioterapico orale in pazienti di eta pediatrica con dirrea acuta]. Minerva Medica 1996;87(11):545-50.

\section{Morrow 2010 \{published data only\}}

Morrow LE, Kollef MH, Casale TB. Probiotic prophylaxis of ventilator-associated pneumonia: a blinded, randomized, controlled trial. American Journal of Respiratory and Critical Care Medicine 2010;182(8):1058-64.

Nista 2004 \{published data only\}

Nista EC, Candelli M, Cremonini F, Cazzato IA, Zocco MA, Franceschi F, et al. Bacillus clausii therapy to reduce side-effects of anti-Helicobacter pylori treatment: randomized, doubleblind,placebo controlled trial. Alimentary Pharmacology \& Therapeutics 2004;20(10):1181-8.

\section{Pancheva 2009 \{published data only\}}

Pancheva R, Stoeva K, Georgieva M, Bliznakova D, Gylybova M, Ivanova $L$, et al. A randomized controlled trial on the effect of a combination of Lactobacillus acidophilus, Lactobacillus delbruecki subsp. Bulgaricus and Bifidobacterium bifidumin the prophylaxis of vomiting and diarrhoea of hospitalised children 1 to 7 years of age. Journal of Pediatric Gastroenterology and Nutrition 2009;48(Suppl 3):E111.

\section{Parfenov 2005 \{published data only\}}

Parfenov AI, Ruchkina IN, Tsaregorodtsev TM, Serova TI. Clinical efficacy of Actimel for patients with the irritated bowel syndrome with prevailing diarrhea. Experimental \& Clinical Gastroenterology 2005;5:45-52.

\section{Park 2007 \{published data only\}}

Park SK, Park DI, Choi JS, Kang MS, Park JH, Kim HJ, et al. The effect of probiotics on Helicobacter pylori eradication. Hepatogastroenterology 2007;54(79):2032-6.

\section{Penna 2009 \{published data only\}}

Penna FGC, Loures MD, de Carvalho AB, Pimenta JR, Figueiredo PCP, Filho LAP, et al. Lack of effect of Lactobacillus delbrueckii H2B20 in the prevention of diarrhea in children hospitalized for short period [La falta de efecto de Lactobacillus delbrueckii H2B20 en la prevención de la diarrea en niños hospitalizados a corto plazo]. Pediatria (São Paulo) 2009;31:76-80.
Plewinska 2006 \{published data only\}

Plewińska EM, Płaneta-Małecka I, Bąk-Romaniszyn L, Czkwianianc E, Małecka-Panas E. Probiotics in the treatment of Helicobacter pylori infection in children. Gastroenterologia Polska 2006;13:315-9.

\section{Saavedra 1994 \{published data only\}}

Saavedra NA, Oung I, Perman JA, Yolken RH. Feeding of Bifidobacterium bifidum and Streptococcus thermophilus to infants in hospital for prevention of diarrhoea and shedding of rotavirus. Lancet 1994;344(8929):1046-9.

\section{Savas-Erdeve 2009 \{published data only\}}

Savas-Erdeve S, Gökay S, Dallar Y. Efficacy and safety of Saccharomyces boulardii in amebiasis-associated diarrhea in children. Turkish Journal of Pediatrics 2009;51(3):220-4.

\section{Schrezenmeir 2004 \{published data only\}}

Schrezenmeir J, Heller K, McCue M, Llamas C, Lam W, Burow H, et al. Benefits of oral supplementation with and without synbiotics in young children with acute bacterial infections. Clinical Pediatrics 2004;43(3):239-49.

\section{Seki 2003 \{published data only\}}

Seki H, Shiohara M, Matsumura T, Miyagawa N, Tanaka M, Komiyama A, et al. Prevention of antibiotic-associated diarrhea in children by Clostridium butyricum MIYAIRI. Pediatrics International 2003;45(1):86-90.

Siitonen 1990 \{published data only\}

Siitonen S, Vapaatalo H, Salminen S, Gordin A, Saxelin M, Wikberg R, et al. Effect of Lactobacillus $G G$ yoghurt in prevention of antibiotic associated diarrhoea. Annals of Medicine 1990;22(1):57-9.

\section{Simakachorn 2011 \{published data only\}}

Simakachorn N, Bibiloni R, Yimyaem P, Tongpenyai Y, Varavithaya W, Grathwohl D, et al. Tolerance, safety, and effect on the faecal microbiota of an enteral formula supplemented with pre- and probiotics in critically ill children. Journal of Pediatric Gastroenterology and Nutrition 2011;53(2):174-81.

Srinivasan 2006 \{published data only\}

Srinivasan R, Meyer R, Padmanabhan R, Britto J. Clinical safety of Lactobacillus casei shirota as a probiotic in critically ill children. Journal of Pediatric Gastroenterology and Nutrition 2006;42(2):171-3.

\section{Szajewka 2001 \{published data only\}}

Szajewska H, Kotowska M, Mrukowicz JZ, Armańska M, Mikołajczyk W. Efficacy of Lactobacillus GG in prevention of nosocomial diarrhea in infants. Journal of Pediatrics 2001;138(3):361-5.

\section{Thomas 2001 \{published data only\}}

Thomas MR, Litin SC, Osmon DR, Corr AP, Weaver AL, Lohse CM. Lack of effect of Lactobacillus $G G$ on antibiotic-associated diarrhea: a randomized, placebo-controlled trial. Mayo Clinic Proceedings 2001;76(9):883-9. 


\section{Tolone 2012 \{published data only\}}

Tolone S, Pellino V, Vitaliti G, Lanzafame A, Tolone C. Evaluation of Helicobacter Pylori eradication in pediatric patients by triple therapy plus lactoferrin and probiotics compared to triple therapy alone. Italian Journal of Pediatrics 2012;38:63.

\section{Valsecchi 2014 \{published data only\}}

Valsecchi C, Marseglia A, Montagna L, Tagliacarne SC, Elli M, Licari A, et al. Evaluation of the effects of a probiotic supplementation with respect to placebo on intestinal microflora and secretory IgA production, during antibiotic therapy, in children affected by recurrent airway infections and skin symptoms. Journal of Biological Regulators and Homeostatic Agents 2014;28(1):117-24.

Wanke 2012 \{published data only\}

Wanke M, Szajewska H. Lack of an effect of Lactobacillus reuteri DSM 17938 in preventing nosocomial diarrhea in children: a randomized, double-blind, placebo-controlled trial. Journal of Pediatrics 2012;161(1):40-3.

\section{Weizman 2005 \{published data only\}}

Weizman Z, Asli G, Alsheikh A. Effect of a probiotic infant formula on infections in child care centers: comparison of two probiotic agents. Pediatrics 2005;115(1):5-9.

\section{Wenus 2008 \{published data only\}}

Wenus C, Goll R, Loken EB, Biong AS, Halvorsen DS, Florholmen J. Prevention of antibiotic-associated diarrhoea by a fermented probiotic milk drink. European Journal of Clinical Nutrition 2008;62(2):299-301.

\section{Witsell 1995 \{published data only\}}

Witsell DL, Garrett CG, Yarbrough WG, Dorrestein SP, Drake AF, Weissler MC. Effect of Lactobacillus acidophilus on antibioticassociated gastrointestinal morbidity: a prospective randomized trial. Journal of Otolaryngology 1995;24(4):230-3.

Zoppi 2001 \{published data only\}

Zoppi G, Cinquetti M, Benini A, Bonamini E, Minelli EB. Modulation of the intestinal ecosystem by probiotics and lactulose in children during treatment with ceftriaxone. Current Therapeutic Research 2001;62(5):418-35.

\section{References to ongoing studies}

NCT02722993 \{published and unpublished data\}

NCT02722993. Efficacy of a Probiotic Product in Children With Antibiotic-associated Gastrointestinal Disorders. clinicaltrials.gov/ct2/show/NCT02722993 30 March 2016.

\section{NCT02765217 \{published and unpublished data\}}

NCT02765217. Effect of Lactobacillus Reuteri DSM 17938 to Prevent Antibiotic-associated Diarrhea in Children (PEARL) [Effect of Lactobacillus Reuteri DSM 17938 to Prevent Antibioticassociated Diarrhea in Children: Prospective, Multi-center, Randomize, Parallel Group Placebo Controlled Clinical Trial]. clinicaltrials.gov/ct2/show/NCT02765217 6 May 2016.

\section{NCT02993419 \{published data only\}}

NCT02993419. Bacillus Particles Prevent Children Antibiotics Associated Diarrhea [Bacillus Particles Prevent More Children's Antibiotic-associated Diarrhea (AAD), Randomized, Doubleblind, Controlled Clinical Trial]. clinicaltrials.gov/ct2/show/ NCT02993419 15 December 2016.

NCT03181516 \{published data only\}

NCT03181516. Efficacy and Safety of BB-12 Supplemented Strawberry Yogurt For Healthy Children on Antibiotics (PLAY ON). clinicaltrials.gov/ct2/show/NCT03181516 8 June 2017.

NCT03334604 \{published and unpublished data\} NCT03334604. The Effect of a Multispecies Probiotic on Reducing the Incidence of Antibiotic-associated Diarrhoea in Children. clinicaltrials.gov/ct2/show/NCT03334604 7 November 2017.

\section{Additional references}

\section{Akl 2009}

Akl EA, Briel M, You JJ, Lamontagne F, Gangji A, CukiermanYaffe T, et al. LOST to follow-up Information in Trials (LOST-IT): a protocol on the potential impact. Trials 2009;10:40.

\section{Bafeta 2018}

Bafeta A, Koh M, Riveros C, Ravaud P. Harms Reporting in Randomized ControlledTrials of Interventions Aimed at Modifying Microbiota: A Systematic Review. Ann Intern Med 2018 Aug 21;169(4):240-7.

\section{Bartlett 1978}

Bartlett JG, Chang TW, Gurwith M, Gorbach SL, Onderdonk AB. Antibiotic-associated pseudomembranous colitis due to toxin-producing clostridia. New England Journal of Medicine 1978;298(10):531-4.

\section{Berrington 2004}

Berrington A, Borriello SP, Brazier J, Duckworth G, Foster K, Freeman R, et al. National Clostridium difficile Standards Group: Report to the Department of Health. Journal of Hospital Infection 2004;56 Suppl 1:1-38.

\section{Bin-Nun 2005}

Bin-Nun A, Bromiker R, Wilschanski M, Kaplan M, Rudensky B, Caplan $\mathrm{M}$, et al. Oral probiotics prevent necrotizing enterocolitis in very low birth weight neonates. Journal of Pediatrics 2005;147(2):192-6

\section{Borriello 2003}

Borriello SP, Hammes WP, Holzapfel W, Marteau P, Schrezenmeir J, Vaara M, et al. Safety of probiotics that contain Lactobacilli or Bifidobacteria. Clinical Infectious Diseases 2003;36(3):775-80.

\section{Cremonini 2002}

Cremonini F, Di Caro S, Nista EC, Bartolozzi F, Capelli G, Gasbarrini G, et al. Meta-analysis: the effect of probiotic administration on antibiotic-associated diarrhoea. Alimentary Pharmacology and Therapeutics 2002;16(8):1461-7. 


\section{Cunningham-Rundles 2000}

Cunningham-Rundles $S$, Ahrne S, Bengmark S, Johann-Liang R, Marshall F, Metakis L, et al. Probiotics and immune response. American Journal of Gastroenterology 2000;95(1 Suppl):S22-5.

\section{D'Souza 2002}

D'Souza AL, Rajkumar C, Cooke J, Bulpitt CJ. Probiotics in the prevention of antibiotic associated diarrhoea: meta-analysis. BMJ 2002;324(7350):1361-6.

\section{Davis 2010}

Davis LM, Martinez I, Walter J, Hutkins R. A dose dependent impact of prebiotic galactooligosaccharides on the intestinal microbiota of healthy adults. International Journal of Food Microbiology 2010;144(2):285-92.

\section{Didary 2014}

Didari T, Solki S, Mozaffari S, Nikfar S, Abdollahi M. A systematic review of the safety of probiotics. Expert Opinion on Drug Safety 2014;13(2):227-39.

\section{Duval 2001}

Duval S, Tweedie R. Trim and fill: A simple funnel-plot-based method of testing and adjusting for publication bias in metaanalysis. Biometrics 2001;56(2):455-63.

\section{Elstner 1983}

Elstner CL, Lindsay AN, Book LS, Matsen JM. Lack of relationship of Clostridium difficile to antibiotic-associated diarrhea in children. Pediatric Infectious Disease 1983;2(5):364-6.

\section{Ferreira 2007}

Ferreira-González I, Busse JW, Heels-Ansdell D, Montori VM, Akl EA, Bryant DM, et al. Problems with use of composite end points in cardiovascular trials:systematic review of randomised controlled trials. BMJ 2007;334(7597):786.

\section{Gibson 1998}

Gibson GR. Dietary modulation of the human gut microflora using prebiotics. British Journal of Nutrition 1998;80(4):S209-12.

\section{Gibson 2004}

Gibson GR, Probert HM, Loo JV, Rastall RA, Roberfroid MB. Dietary modulation of the human colonic microbiota: Updating the concept of prebiotics. Nutrition Research Reviews 2004;17(2):259-75.

\section{Gogate 2005}

Gogate A, De A, Nanivadekar R, Mathur M, Saraswathi K, Jog A, et al. Diagnostic role of stool culture and toxin detection in antibiotic associated diarrhoea due to Clostridium difficile in children. Indian Journal of Medical Research 2005;122(6):518-24.

\section{Goldin 1998}

Goldin BR. Health benefits of probiotics. British Journal of Nutrition 1998;80(4):S203-7.

\section{Guyatt 2008}

Guyatt GH, Oxman AD, Kunz R, Vist GE, Falck-Ytter Y, Schünemann $\mathrm{HJ}$, et al. What is "quality of evidence" and why is it important to clinicians?. BMJ 2008;336(7651):995-8.

\section{Hammerman 2006}

Hammerman C, Bin-Nun A, Kaplan M. Safety of probiotics: comparison of two popular strains. BMJ 2006;333(7576):1006-8.

\section{Hartling 2009}

Hartling L, Ospina M, Liang Y, Dryden DM, Hooton N, Krebs Seida J, et al. Risk of bias versus quality assessment of randomised controlled trials: cross sectional study. BMJ 2009;339:b4012.

\section{Hassan 2018}

Hassan H, Rompola M, Glaser AW, Kinsey SE, Phillips RS. Systematic review and meta-analysis investigating the efficacy and safety of probiotics in people with cancer. Support Care Cancer 2018;26(8):2503-9.

\section{Hata 1988}

Hata D, Yoshida A, Ohkubo H, Mochizuki Y, Hosoki Y, Tanaka R, et al. Meningitis caused by bifidobacterium in an infant. Pediatric Infectious Disease Journal 1988;7(9):669-71.

\section{Hempel 2011}

Hempel S, Newberry S, Ruelaz A, Wang Z, Miles JN, Suttorp MJ, et al. Safety of probiotics used to reduce risk and prevent or treat disease. Evidence Report/Technology Assessment 2011;200:1-645.

\section{Higgins 2003}

Higgins JP, Thompson SG, Deeks JJ, Altman DG. Measuring inconsistency in meta-analyses. BMJ 2003;327(7414):557-60.

\section{Hollis 1999}

Hollis S, Campbell F. What is meant by intention to treat analysis? Survey of published randomised controlled trials. BMJ 1999;319(7211):670-4.

\section{loannidis 2004}

Ioannidis JP, Evans SJ, Gøtzsche PC, O'Neill RT, Altman DG, Schulz K, et al. Better reporting of harms in randomized trials: an extension of the CONSORT statement. Annals of Internal Medicine 2004;141(10):781-8.

\section{Janda 2007}

Janda JM, Abbott SL. 16S rRNA gene sequencing for bacterial identification in the diagnostic laboratory: pluses, perils, and pitfalls. Journal of Clinical Microbiology 2007;45(9):2761-4.

\section{Johnston 2006}

Johnston BC, Supina AL, Vohra S. Probiotics for pediatric antibiotic-associated diarrhea: a meta-analysis of randomized placebo-controlled trials. CMAJ: Canadian Medical Association Journal 2006;175(4):377-83.

\section{Johnston 2010}

Johnston BC, Shamseer L, da Costa BR, Tsuyuki RT, Vohra S. Measurement issues in trials of pediatric acute diarrheal diseases: a systematic review. Pediatrics 2010;126(1):e222-31.

\section{Johnston 2013}

Johnston BC, Donen R, Pooni A, Pond J, Xie F, Giglia L, et al. Conceptual framework for health-related quality of life 
assessment in acute gastroenteritis. Journal of Pediatric Gastroenterology and Nutrition 2013;56(3):280-9.

\section{Kale-Pradhan 2010}

Kale-Pradhan PB, Jassal HK, Wilhelm SM. Role of Lactobacillus in the prevention of antibiotic-associated diarrhea: a metaanalysis. Pharmacotherapy 2010;30(2):119-26.

\section{Land 2005}

Land MH, Rouster-Stevens K, Woods CR, Cannon ML, Cnota J, Shetty AK. Lactobacillus sepsis associated with probiotic therapy. Pediatrics 2005;115(1):178-81.

\section{Lin 2005}

Lin HC, Su BH, Chen AC, Lin TW, Tsai CH, Yeh TF, et al. Oral probiotics reduce the incidence and severity of necrotizing enterocolitis in very low birth weight infants. Pediatrics 2005;115(1):1-4

\section{Mackay 1999}

Mackay AD, Taylor MB, Kibbler CC, Hamilton-Miller JM. Lactobacillus endocarditis caused by a probiotic organism. Clinical Microbiology and Infection 1999;5(5):290-2.

\section{Madsen 2001}

Madsen KL. The use of probiotics in gastrointestinal disease. Canadian Journal of Gastroenterology 2001;15(12):817-22.

\section{McFarland 1998}

McFarland LV. Epidemiology, risk factors and treatments for antibiotic-associated diarrhea. Digestive Diseases 1998;16(5):292-307.

\section{McFarland 2006}

McFarland LV. Meta-analysis of probiotics for the prevention of antibiotic associated diarrhea and the treatment of Clostridium difficile disease. American Journal of Gastroenterology 2006;101(4):812-22.

\section{McFarland 2008}

McFarland LV. Antibiotic-associated diarrhea: epidemiology, trends and treatment. Future Microbiology 2008;3(5):563-78.

\section{McFarland 2010}

McFarland LV. Systematic review and meta-analysis of Saccharomyces boulardiii adult patients. World Journal of Gastroenterology 2010;16(18):2202-22.

\section{McFarland 2015}

McFarland LV. Deciphering meta-analytic results: a minireview of probiotics for the prevention of paediatric antibioticassociated diarrhoea and Clostridium difficile infections. Beneficial Microbes 2015;6(2):189-94.

\section{Mclnnes 2010}

Mclnnes P, Cutting M. Manual of procedures for human microbiome project: Core microbiome sampling, protocol A. www.ncbi.nlm.nih.gov/projects/gap/cgi-bin/GetPdf.cgi? id=phd002854.2 (accessed 5 December 2018).

\section{Ouwehand 2017}

Ouwehand AC. A review of dose-responses of probiotics in human studies. Beneficial Microbes 2017;8(2):143-51.

\section{Owens 2008}

Owens RC Jr, Donskey CJ, Gaynes RP, Loo VG, Muto CA. Antimicrobial-associated risk factors for Clostridium difficile infection. Clinical Infectious Diseases 2008;46 Suppl 1:S19-31.

\section{Piarroux 1999}

Piarroux R, Millon L, Bardonnet K, Vagner O, Koenig H. Are live Saccharomyces yeasts harmful to patients?. Lancet 1999;353(9167):1851-2.

\section{Rautio 1999}

Rautio M, Jousimies-Somer H, Kauma H, Pietarinen I, Saxelin M, Tynkkynen S, et al. Liver abscess due to a Lactobacillus rhamnosus strain indistinguishable from L. rhamnosus strain GG. Clinical Infectious Diseases 1999;28(5):1159-60.

\section{Raza 1995}

Raza S, Graham SM, Allen SJ, Sultana S, Cuevas L, Hart CA. Lactobacillus $G G$ promotes recovery from acute nonbloody diarrhea in Pakistan. Pediatric Infectious Disease Journal 1995;14(2):107-11.

\section{Roberfroid 1998}

Roberfroid MB. Prebiotics and synbiotics: concepts and nutritional properties. British Journal of Nutrition 1998;80(4):S197-202.

\section{Saavedra 1999}

Saavedra JM. Probiotics plus antibiotics: regulating our bacterial environment. Journal of Pediatrics 1999;135(5):535-7.

\section{Salminen 1998}

Salminen S, von Wright A, Morelli L, Marteau P, Brassart D, de Vos WM, et al. Demonstration of safety of probiotics -- a review. International Journal of Food Microbiology 1998;44(1-2):93-106

\section{Salminen 2004}

Salminen MK, Rautelin H, Tynkkynen S, Poussa T, Saxelin M, Valtonen V, et al. Lactobacillus bacteremia, clinical significance, and patient outcome, with special focus on probiotic $L$. rhamnosus GG. Clinical Infectious Diseases 2004;38(1):62-9.

\section{Saxelin 1996}

Saxelin M, Chuang NH, Chassy B, Rautelin H, Makela PH, Salminen $\mathrm{S}$, et al. Lactobacilli and bacteremia in southern Finland, 1989-1992. Clinical Infectious Diseases 1996;22(3):564-6.

\section{Sazawal 2006}

Sazawal S, Hiremath G, Dhingra U, Malik P, Deb S, Black RE. Efficacy of probiotics in prevention of acute diarrhoea: a metaanalysis of masked, randomised, placebo-controlled trials. Lancet Infectious Diseases 2006;6(6):374-82. 


\section{Schrezenmeir 2001}

Schrezenmeir J, de Vrese M. Probiotics, prebiotics, and synbiotics -- approaching a definition. American Journal of Clinical Nutrition 2001;73(2 Suppl):361S-4S.

\section{Sterne 2011}

Sterne JA, Sutton AJ, Ioannidis JP, Terrin N, Jones DR, Lau J, et al. Recommendations for examining and interpreting funnel plot asymmetry in meta-analyses of randomised controlled trials. BMJ 2011;343:d4002.

\section{Suez 2018}

Suez J, Zmora N, Zilberman-Schapira G, Mor U, Dori-Bachash M, Bashiardes S, et al. Post-Antibiotic Gut Mucosal Microbiome Reconstitution Is Impaired by Probioticsand Improved by Autologous FMT. Cell 2018;174(6):1406-1423, e1-e6.

\section{Sun 2014}

Sun X, loannidis JP, Agoritsas T, Alba AC, Guyatt G. How to use a subgroup analysis: users' guide to the medical literature. JAMA 2014;311(4):405-11.

\section{Sussman 1986}

Sussman JI, Baron EJ, Goldberg SM, Kaplan MH, Pizzarello RA. Clinical manifestations and therapy of Lactobacillus endocarditis: report of a case and review of the literature. Reviews of Infectious Diseases 1986;8(5):771-6.

\section{Szajewska 2005}

Szajewska H, Mrukowicz J. Meta-analysis: non-pathogenic yeast Saccharomyces boulardii in the prevention of antibioticassociated diarrhoea. Alimentary Pharmacology and Therapeutics 2005;22(5):365-72.

\section{Szajewska 2006}

Szajewska H, Ruszczyński M, Radzikowski A. Probiotics in the prevention of antibiotic-associated diarrhea in children: a metaanalysis of randomized controlled trials. Journal of Pediatrics 2006;149(3):367-72.

\section{Szajewska 2015}

Szajewska H, Kołodziej M. Systematic review with metaanalysis: Lactobacillus rhamnosus $G G$ in the prevention

\section{CHARACTERISTICS OF STUDIES}

Characteristics of included studies [ordered by study ID] of antibiotic-associated diarrhoea in children and adults. Alimentary Pharmacology \& Therapeutics 2015;42(10):1149-57.

\section{Turck 2003}

Turck D, Bernet JP, Marx J, Kempf H, Giard P, Walbaum O, et al. Incidence and risk factors for of oral antibiotic-associated diarrhea in an outpatient pediatric population. Journal of Pediatric Gastroenterology and Nutrition 2003;37(1):22-6.

\section{Whelan 2010}

Whelan K, Myers CE. Safety of probiotics in patients receiving nutritional support: a systematic review of case reports, randomized controlled trials, and nonrandomized trials. American Journal of Clinical Nutrition 2010;91(3):687-703.

\section{Wistrom 2001}

Wistrom J, Norrby SR, Myhre EB, Eriksson S, Granstrom G, Lagergren $L$, et al. Frequency of antibiotic-associated diarrhoea in 2462 antibiotic-treated hospitalized patients: a prospective study. Journal of Antimicrobial Chemotherapy 2001;47(1):43-50

\section{References to other published versions of this review \\ Goldenberg 2015}

Goldenberg JZ, Lytvyn L, Steurich J, Parkin P, Mahant S, Johnston BC. Probiotics for the prevention of pediatric antibiotic-associated diarrhea. Cochrane Database of Systematic Reviews 2015, Issue 12. [DOI: 10.1002/14651858.CD004827.pub4]

\section{Johnston 2007}

Johnston BC, Supina AL, Ospina M, Vohra S. Probiotics for the prevention of pediatric antibiotic-associated diarrhea. Cochrane Database of Systematic Reviews 2007, Issue 2. [DOI: 10.1002/14651858.CD004827.pub2]

\section{Johnston 2011}

Johnston BC, Goldenberg JZ, Vandvik PO, Sun X, Guyatt GH. Probiotics for the prevention of pediatric antibiotic-associated diarrhea. Cochrane Database of Systematic Reviews 2011, Issue 11. [DOI: 10.1002/14651858.CD004827.pub3]

* Indicates the major publication for the study

Arvola 1999

$\begin{array}{ll}\text { Methods } & \text { Randomized, placebo-controlled, double-blinded } \\ & \text { Withdrawals/loss to follow-up: } 48 \text { participants }(28.7 \%) \\ \text { ITT: no } & \\ \text { Period of follow-up: } 3 \text { months } & \\ \text { Participants } & \text { Diagnosis: (acute RTIs) } \\ & \text { Country: Finland } \\ & \text { Setting: Health Care Centers - City of Tampere and Tampere University Hospital }\end{array}$


Arvola 1999 (Continued)

Age: 2 weeks to 12.8 yrs (mean $4.5 \mathrm{yrs}$ )

Probiotics: Lactobacillus GG (4 billion CFUs/day orally over two weeks)

Antibiotics: Not specified

$\begin{array}{ll}\text { Outcomes } & \text { ID (treatment } 5 \% \text { versus placebo } 16 \%) \\ & \text { MSF (treatment \& placebo } 4 \text { ( } 2 \text { to } 8) \\ & \text { MDD (treatment \& placebo } 5 \text { ( } 3 \text { to } 6 \text { ) } \\ & \text { Definition of diarrhea: at least } 3 \text { watery or loose stools/day for a minimum of } 2 \text { consecutive days }\end{array}$

Notes Funding = Not reported

\section{Risk of bias}

\section{Bias Authors' judgement Support for judgement}

Random sequence genera- Low risk Computer generated tion (selection bias)

\begin{tabular}{lll}
\hline $\begin{array}{l}\text { Allocation concealment } \\
\text { (selection bias) }\end{array}$ & Unclear risk & Not described \\
\hline $\begin{array}{l}\text { Blinding (performance } \\
\text { bias and detection bias) }\end{array}$ & Low risk & $\begin{array}{l}\text { Lactobacillus GG and placebo capsules were indistinguishable in appearance } \\
\text { and taste }\end{array}$ \\
\hline
\end{tabular}

\begin{tabular}{lll}
$\begin{array}{l}\text { Incomplete outcome data } \\
\text { (attrition bias) } \\
\text { All outcomes }\end{array}$ & High risk & Withdrawals/loss to follow-up: 48 participants (28.7\%) \\
\hline $\begin{array}{l}\text { Selective reporting (re- } \\
\text { porting bias) }\end{array}$ & Unclear risk & Without protocol and register information \\
\hline Other bias & Low risk & The study appears to be free of other sources of bias \\
\hline
\end{tabular}

Benhamou 1999

\begin{tabular}{ll}
\hline Methods & $\begin{array}{l}\text { Randomized, active-controlled, double-blinded } \\
\text { Withdrawals/loss to follow-up: } 163 \text { participants (21\%) } \\
\text { ITT: no } \\
\text { Period of follow-up: length of antibiotic intervention }\end{array}$ \\
\hline Participants & $\begin{array}{l}\mathrm{N}=779 \text { enrolled } \\
\text { Diagnosis: NS } \\
\text { Country: France } \\
\text { Setting: Community care practices, Age: } 1 \text { to } 5 \text { years }\end{array}$ \\
\hline Interventions & $\begin{array}{l}\text { Probiotic: SB (4.5 billion CFUs/day) } \\
\text { Control: Diosmectite } 6 \text { g/day (1 to } 2 \text { years), } 9 \text { g/day (> 2 years), } \\
\text { Antibiotic: not specified }\end{array}$ \\
\hline Outcomes & $\begin{array}{l}\text { ID (treatment } 7.6 \%, \text { diosmectite } 5.5 \%) \\
\text { Definition of diarrhea: }>3 \text { liquid stools/day }\end{array}$ \\
\hline Notes & Funding = Not reported \\
\hline
\end{tabular}


Benhamou 1999 (Continued)

\section{Risk of bias}

\begin{tabular}{|c|c|c|}
\hline Bias & Authors' judgement & Support for judgement \\
\hline $\begin{array}{l}\text { Random sequence genera- } \\
\text { tion (selection bias) }\end{array}$ & Unclear risk & Mentioned randomization, otherwise not described \\
\hline $\begin{array}{l}\text { Allocation concealment } \\
\text { (selection bias) }\end{array}$ & Unclear risk & Not described \\
\hline $\begin{array}{l}\text { Blinding (performance } \\
\text { bias and detection bias) } \\
\text { All outcomes }\end{array}$ & Unclear risk & Described as "double blind" without further details \\
\hline $\begin{array}{l}\text { Incomplete outcome data } \\
\text { (attrition bias) } \\
\text { All outcomes }\end{array}$ & High risk & $\begin{array}{l}\text { Withdrawals/loss to follow-up: } 163 \text { participants }(21 \%) \text {. The authors do not de- } \\
\text { scribe what happened to these patients }\end{array}$ \\
\hline $\begin{array}{l}\text { Selective reporting (re- } \\
\text { porting bias) }\end{array}$ & Unclear risk & Not reported. No protocol and registered \\
\hline Other bias & Unclear risk & No funding from industry or other sources mentioned \\
\hline
\end{tabular}

Conway 2007

Randomised, controlled trial ( 3 arms), double-blind
Withdrawals/ losses to follow-up: 0 (data provided by authors)
ITT: yes, but NA (obtained pediatric data from authors)
Period of Follow-up: 12 days

\begin{tabular}{ll}
\hline Participants & Diagnosis: NS \\
Country: England \\
Setting: rural general practice
\end{tabular}

Age: 1 to 17 years inclusive

Interventions $\quad$ Probiotics: ST, LA, BA, LD (1 billion CFUs bacteria/day)
Antibiotics: NS

Antibiotics: NS

Outcomes ID (treatment $10.8 \%$ versus control $6.3 \%$ )

Definition of diarrhea: 3 or more loose or liquid stools on at least 2 consecutive days

Notes $\quad$ Funding: Industry (medications)

\section{Risk of bias}


Conway 2007 (Continued)

Random sequence genera- Low risk Random number table tion (selection bias)

Allocation concealment $\quad$ Low risk $\quad$ Sealed opaque envelopes
(selection bias)

\begin{tabular}{ll}
\hline $\begin{array}{l}\text { Blinding (performance } \\
\text { bias and detection bias) }\end{array}$ & High risk \\
All outcomes & $\begin{array}{l}\text { Blinding for the two groups allocated to yogurts. Third group not blinded. To } \\
\text { avoid unit of analysis errors, we combined the yogurt groups and compared } \\
\text { against the third group (no treatment control). Given our analysis technique, } \\
\text { will consider un-blinded }\end{array}$
\end{tabular}

\begin{tabular}{|c|c|c|}
\hline $\begin{array}{l}\text { Incomplete outcome data } \\
\text { (attrition bias) } \\
\text { All outcomes }\end{array}$ & Unclear risk & $\begin{array}{l}\text { Overall, } 38 \text { patients were LTFU from the adults and child data combined }(n= \\
12, n=9, n=17) \text {. It is unclear how many children specifically were lost to fol- } \\
\text { low-up }\end{array}$ \\
\hline
\end{tabular}

\begin{tabular}{lll}
\hline $\begin{array}{l}\text { Selective reporting (re- } \\
\text { porting bias) }\end{array}$ & Unclear risk & Not reported. No protocol and register information \\
\hline Other bias & Low risk & $\begin{array}{l}\text { Acknowledged by authors: Imbalance for previous AAD might have distorted } \\
\text { main outcome results }\end{array}$ \\
\hline
\end{tabular}

\section{Correa 2005}

\begin{tabular}{|c|c|c|}
\hline Methods & \multicolumn{2}{|c|}{$\begin{array}{l}\text { Randomized, formula-controlled, double-blinded. } \\
\text { Withdrawals/loss to follow-up: } 12 \\
\text { ITT: No } \\
\text { Period of follow-up: } 15 \text { days }\end{array}$} \\
\hline Participants & \multicolumn{2}{|c|}{$\begin{array}{l}\mathrm{N}=169 \text { enrolled } \\
\text { Diagnosis: NS } \\
\text { Country: Brasil } \\
\text { Setting: Hospital ambulatory care } \\
\text { Age: mean } 1.8 \text { years }\end{array}$} \\
\hline Interventions & \multicolumn{2}{|c|}{$\begin{array}{l}\text { Probiotic: BL, ST (approximately } 825 \text { million CFUs/day) } \\
\text { Control: Formula ( } 3.3 \text { g protein, } 4.4 \text { g fat, } 11.8 \text { g carbohydrates per } 100 \text { kcal plus vitamins and minerals) } \\
\text { Antibiotics: ampicillin } n=119 \text {, amoxicillin } n=101 \text {, cephalosporin } n=31 \text {, amoxicillin+clavulanic acid } n= \\
\text { 16, penicillin } n=10 \text {, oxacillin } n=9 \text {, others } n=20\end{array}$} \\
\hline Outcomes & \multicolumn{2}{|c|}{$\begin{array}{l}\text { ID (treatment } 16.3 \% \text { versus control } 31.2 \% \text { ) } \\
\text { MDD (treatment } 3.92+/-2.47 \text { versus control } 5.00+/-2.80 \text { ) } \\
\text { Definition of diarrhea: } 3 \text { or more liquid stools/day for at least } 2 \text { consecutive days }\end{array}$} \\
\hline Notes & \multicolumn{2}{|c|}{ Funding = Industry (Nestle, otherwise unclear re: medications versus operations) and independent } \\
\hline \multicolumn{3}{|l|}{ Risk of bias } \\
\hline Bias & Authors' judgement & Support for judgement \\
\hline $\begin{array}{l}\text { Random sequence genera- } \\
\text { tion (selection bias) }\end{array}$ & Unclear risk & Not described \\
\hline $\begin{array}{l}\text { Allocation concealment } \\
\text { (selection bias) }\end{array}$ & Unclear risk & Not described \\
\hline
\end{tabular}




\section{Correa 2005 (Continued)}

Blinding (performance Low risk Double-blind: The appearance and odour of the probiotic and non-supplebias and detection bias) mented formulas were identical

All outcomes

$\begin{array}{ll}\begin{array}{l}\text { Incomplete outcome data } \\ \text { (attrition bias) }\end{array} & \begin{array}{l}12 \text { patients dropped out ( }<10 \% \text { and relatively even for each group). } 7 \text { from pro- } \\ \text { biotic } 5 \text { from control. Reasons why are given. However the reasons given were } \\ \text { All outcomes }\end{array} \\ & \begin{array}{l}\text { not evenly distributed. Control lost } 4 \text { from loss to follow-up while probiotic lost } \\ \text { none for that reason. Probiotic lost } 5 \text { from insufficient ingestion and control } \\ \text { lost none for that reason. However, the minimum amount needed for inges- } \\ \text { tion was described seemingly a priori }\end{array}\end{array}$

Selective reporting (re- Unclear risk Not reported. No protocol and register information.
porting bias)

Other bias Unclear risk Nestle the maker of the probiotic intervention provided some funding. The report is not co-authored by the company, however there is no clear mention of Nestle's involvement beyond that of providing the product

Destura unpublished

\begin{tabular}{ll}
\hline Methods & Randomized, no intervention controlled, open label trial \\
& Withdrawals/loss to follow-up: 0 (data provided by authors) \\
ITT: N/A & Period of follow-up: until end of antibiotic therapy (7 to 21 days) \\
\hline Participants & Diagnosis: respiratory, genito-urinary, skin and soft tissue infections \\
& Country: the Philippines \\
& Setting: hospital general care (inpatient and outpatient) \\
& Age: treatment 4.1 years and control 4 years (means) \\
& Probiotics: BC (4 billion CFUs bacteria/day) \\
Antibiotics: Penicillins $n=151$, cephalosporin $\mathrm{n}=112$, coamoxyclav/ampicillin-sulbactam $\mathrm{n}=25$, other \\
$\mathrm{n}=35$
\end{tabular}

Outcomes ID: $1.85 \%$ treatment versus $4.35 \%$ control

MDD: 4.00 (SD 3.46) treatment versus 3.86 (SD 2.26) control

Definition of diarrhea: change in bowel habits with the passage of three or more liquid stools per day for at least 2 consecutive days 48 hours after initiation of antibiotic therapy

Notes $\quad$ Funding: Industry (otherwise unclear re: medications versus operations)

\section{Risk of bias}

\begin{tabular}{lll}
\hline Bias & Authors' judgement & Support for judgement \\
\hline $\begin{array}{l}\text { Random sequence genera- } \\
\text { tion (selection bias) }\end{array}$ & Low risk & $\begin{array}{l}\text { Complete blocks of varying sizes were randomly allocated by a "third party" } \\
\text { through a central telephone randomization system }\end{array}$ \\
\hline
\end{tabular}


Destura unpublished (Continued)

$\begin{array}{ll}\begin{array}{l}\text { Allocation concealment } \quad \text { Unclear risk } \\ \text { (selection bias) }\end{array} & \text { "Complete blocks of varying sizes were randomly allocated by a "third par- } \\ & \text { ty" through a central telephone randomization system." "Each patient was } \\ \text { identified using a center number, a treatment number (provided by the treat- } & \text { ment code found in the intervention drug label) and the patient's initials." "a } \\ & \text { research assistant assigned per center kept the randomization plan and only } \\ & \text { opened it when an eligible patient was entered in the study" }\end{array}$

\begin{tabular}{|c|c|c|}
\hline $\begin{array}{l}\text { Blinding (performance } \\
\text { bias and detection bias) } \\
\text { All outcomes }\end{array}$ & High risk & Blinding not used - open label study \\
\hline $\begin{array}{l}\text { Incomplete outcome data } \\
\text { (attrition bias) } \\
\text { All outcomes }\end{array}$ & Low risk & $\begin{array}{l}\text { Two patients were lost to follow-up ( } 1 \text { in each arm) after clinical outcomes } \\
\text { were measured. So there was no missing outcome data }\end{array}$ \\
\hline $\begin{array}{l}\text { Selective reporting (re- } \\
\text { porting bias) }\end{array}$ & Low risk & $\begin{array}{l}\text { Protocol posted on clinicaltrials.gov (NCT00447161) and results as presented } \\
\text { to us by authors match up }\end{array}$ \\
\hline Other bias & Low risk & $\begin{array}{l}\text { Study funded by industry. Not clear if author is employed by industry but as- } \\
\text { sume so. Also no clear statement regarding industry involvement is trial de- } \\
\text { sign. The study appears to be free of other sources of bias }\end{array}$ \\
\hline
\end{tabular}

Dharani 2017

A randomized, single blinded trial
Withdrawals/Loss to follow-up: 0
ITT: N/A
Period of follow-up: At the end of five days of treatment

\begin{tabular}{ll}
\hline Participants & $\mathrm{N}=100$ \\
& Diagnosis: Patients with impetigo \\
& Country: India \\
& Setting: Outpatient departments \\
& Age: 1 to 15 years old \\
\hline Interventions & Probiotics: Lactobacillus sporegens (50 million spores), Streptococcus faecalis (30 million spores), \\
Clostridium butyricum ( 2 million spores) and Bacillus mesentericus (1 million spores) twice daily for 5 \\
days \\
Antibiotics: Azithromycin $10 \mathrm{mg} / \mathrm{kg} /$ day for 5 days \\
ID: 0 in treatment (0/50), 3 in control (3/50) \\
Definition of diarrhea: Not reported
\end{tabular}

Notes

Funding: Not reported

\section{Risk of bias}


Dharani 2017 (Continued)

$\begin{aligned} & \text { Random sequence genera- } \\ & \text { tion (selection bias) }\end{aligned} \quad \begin{aligned} & \text { "A prospective randomized single blinded interventional study". However, the } \\ & \text { sequence generation process was not reported }\end{aligned}$

\begin{tabular}{l}
$\begin{array}{l}\text { Allocation concealment } \\
\text { (selection bias) }\end{array}$ Unclear risk The method used to conceal allocation sequence was not reported \\
\hline
\end{tabular}

(selection bias)

Blinding (performance $\quad$ Unclear risk
bias and detection bias)

All outcomes
The author described the study as single blinded. However, there is no information regarding who was blinded or how blinding was done. We assumed it was difficult to blind patients (or parents) and clinicians because the number of drugs used in the two groups of patients was different (azithromycin plus probiotic in treatment, azithromycin in control). Additionally, the timing of treatment was also different (probiotic 2 hours before meals, azithromycin 2 hours after meals)

\begin{tabular}{lll}
\hline $\begin{array}{l}\text { Incomplete outcome data } \\
\text { (attrition bias) } \\
\text { All outcomes }\end{array}$ & Low risk & No missing outcome data \\
\hline $\begin{array}{l}\text { Selective reporting (re- } \\
\text { porting bias) }\end{array}$ & Unclear risk & There is no published protocol of this trial to assess reporting bias \\
\hline Other bias & Unclear risk & $\begin{array}{l}\text { The source of funding for was not reported. However, with regards to conflict } \\
\text { of interest, the author "declared none" }\end{array}$ \\
\hline
\end{tabular}

\section{Erdeve 2004}

\begin{tabular}{|c|c|c|}
\hline Methods & \multicolumn{2}{|c|}{$\begin{array}{l}\text { Randomized, no treatment controlled. } \\
\text { Withdrawals/loss to follow-up: } 187 \text { participants }(28.6 \%) \\
\text { ITT: no } \\
\text { Period of follow-up: NS }\end{array}$} \\
\hline Participants & \multicolumn{2}{|l|}{$\begin{array}{l}\mathrm{N}=653 \text { enrolled } \\
\text { Diagnosis: NS } \\
\text { Country: Turkey } \\
\text { Setting: Unclear } \\
\text { Age: } 1 \text { to } 15 \text { years }\end{array}$} \\
\hline Interventions & \multicolumn{2}{|c|}{$\begin{array}{l}\text { Probiotic: SB ( } 5 \text { billion CFUs/day) } \\
\text { Antibiotics: Salbactam-ampicillin } n=234 \text {, azithromycin } n=232\end{array}$} \\
\hline Outcomes & \multicolumn{2}{|c|}{$\begin{array}{l}\text { ID (treatment } 5.7 \% \text { versus control } 18.9 \% \text { ) } \\
\text { Definition of diarrhea: Watery stools on } 3 \text { or more times on any day of antibiotic treatment }\end{array}$} \\
\hline Notes & \multicolumn{2}{|l|}{ Funding $=$ Not reported } \\
\hline \multicolumn{3}{|l|}{ Risk of bias } \\
\hline Bias & Authors' judgement & Support for judgement \\
\hline $\begin{array}{l}\text { Random sequence genera- } \\
\text { tion (selection bias) }\end{array}$ & Low risk & $\begin{array}{l}\text { Randomization not described, however, contact with authors indicated that } \\
\text { the trial was randomized }\end{array}$ \\
\hline $\begin{array}{l}\text { Allocation concealment } \\
\text { (selection bias) }\end{array}$ & Unclear risk & Not described \\
\hline
\end{tabular}


Erdeve 2004 (Continued)
Blinding (performance
Unclear risk
No mention is made of blinding
bias and detection bias)

All outcomes

\begin{tabular}{lll}
\hline $\begin{array}{l}\text { Incomplete outcome data } \\
\text { (attrition bias) } \\
\text { All outcomes }\end{array}$ & High risk & $\begin{array}{l}\text { Withdrawals/loss to follow-up: 187 participants (28.6\%). There is no mention } \\
\text { of which proportion of drop outs were from each group }\end{array}$ \\
\hline $\begin{array}{l}\text { Selective reporting (re- } \\
\text { porting bias) }\end{array}$ & Unclear risk & Not reported. No protocol and register information \\
\hline Other bias & Unclear risk & No mention of funding \\
\hline
\end{tabular}

\section{Esposito 2017}

\begin{tabular}{ll}
\hline Methods & A "prospective, randomized, placebo-controlled study" with 3 groups of patients \\
& Withdrawals/loss to follow-up: 0 (data provided by author) \\
ITT: N/A & Period of follow-up: At the end of hospitalization \\
\hline Participants & N $=90$ enrolled \\
Diagnosis: Patients undergoing hypospadias repair \\
Country: Italy \\
Setting: Inpatient \\
Age: 11 to 36 months
\end{tabular}

Interventions Probiotic: Lactobacillus rhamnosus GG (ATCC53103) (5 billion CFUs/day)

Antibiotics: amoxicillin+clavulanate ormacrolide

\begin{tabular}{ll}
\hline Outcomes & ID: treatment $3 / 30(10 \%)$, placebo control $12 / 30(40 \%)$, blank control $15 / 30(50 \%)$ \\
Definition of diarrhea: 3 or more liquid stools in a 24 -hour period (Bristol stool chart, type 7$)$
\end{tabular}

Notes Funding: not reported; no conflict of interest declared

\section{Risk of bias}

\begin{tabular}{lll}
\hline Bias & Authors' judgement & Support for judgement \\
\hline $\begin{array}{l}\text { Random sequence genera- } \\
\text { tion (selection bias) }\end{array}$ & Unclear risk & The randomization process was not described \\
\hline $\begin{array}{l}\text { Allocation concealment } \\
\text { (selection bias) }\end{array}$ & Unclear risk & Not described \\
\hline $\begin{array}{l}\text { Blinding (performance } \\
\text { bias and detection bias) } \\
\text { All outcomes }\end{array}$ & Unclear risk & $\begin{array}{l}\text { Not described. However, participants of the treatment group and the place- } \\
\text { bo control group may not have known whether they were receiving a probi- } \\
\text { otic or not (both were in the form of drops at the same time of day). It would } \\
\text { have been difficult to blind the blank control group as they were receiving few- } \\
\text { er medications }\end{array}$ \\
\hline
\end{tabular}

Incomplete outcome data Low risk $\quad$ All participants completed the study
(attrition bias)

All outcomes 
Esposito 2017 (Continued)

Selective reporting (re- Unclear risk $\quad$ There is no published protocol for assessing reporting bias porting bias)

Other bias

Unclear risk

Source of funding not mentioned. However, they declared no conflict of interest

Fox 2015

\begin{tabular}{|c|c|}
\hline Methods & $\begin{array}{l}\text { Randomized, placebo-controlled, double-blinded } \\
\text { Withdrawals/loss to follow-up: } 2(2.8 \%) \\
\text { ITT: No } \\
\text { Period of follow-up: } 1 \text { week after antibiotic treatment ended }\end{array}$ \\
\hline Participants & $\begin{array}{l}\mathrm{N}=72 \\
\text { Diagnosis: otitis, pharyngitis, chest infections, other } \\
\text { Country: Australia } \\
\text { Setting: multisite general care } \\
\text { Age: Mean age } 6.8 \text { years treatment group, } 6.3 \text { years control group }\end{array}$ \\
\hline Interventions & $\begin{array}{l}\text { Probiotic: } 2 \times 100 \text { gram tubs per day containing; LGG } 5.2 \times 10^{9} \text { CFUs/day, Bb- } 125.9 \times 10^{9} \text { CFUs/day, La- } 5 \\
8.3 \times 10^{9} \text { CFUs/day } \\
\text { Antibiotics: Beta lactams } n=64 \\
\text { Macrolides } n=5 \\
\text { Tetracyclines } n=1\end{array}$ \\
\hline
\end{tabular}

Outcomes ID: $1 / 34(2.9 \%)$ treatment group vs $21 / 36(61.7 \%)$ control. P-value $=<0.001$

Various definitions of diarrhea. These included: (A) stool consistency $\geq 5$ and stool frequency $\geq 2 /$ day for more than 2 days; (B) stool consistency $\geq 5$ and stool frequency $\geq 3 /$ day for more than 2 days; (C) stool consistency $\geq 6$ and stool frequency $\geq 2$ /day for more than 2 days; and (D) stool consistency $\geq 6$ and stool frequency $\geq 3 /$ day for more than 2 days

Notes Funding = Industry provided yogurt but had no input in study design

Independent lab assessed the probiotics

\section{Risk of bias}

\begin{tabular}{lll}
\hline Bias & Authors' judgement & Support for judgement \\
\hline $\begin{array}{l}\text { Random sequence genera- } \\
\text { tion (selection bias) }\end{array}$ & Low risk & $\begin{array}{l}\text { "A statistician generated independent allocation sequences and randomisa- } \\
\text { tion lists for each study site, using the random number generator in Microsoft } \\
\text { Excel" }\end{array}$ \\
\hline $\begin{array}{l}\text { Allocation concealment } \\
\text { (selection bias) }\end{array}$ & Low risk & $\begin{array}{l}\text { "To ensure allocation concealment, an independent person oversaw packag- } \\
\text { ing and labelling of trial treatments based on the randomisation schedule" }\end{array}$ \\
\hline $\begin{array}{l}\text { Blinding (performance } \\
\text { bias and detection bias) } \\
\text { All outcomes }\end{array}$ & Low risk & $\begin{array}{l}\text { "All investigators, participants, outcome assessors and data analysts were } \\
\text { blinded to the assigned treatment throughout the study" } \\
\text { "The yogurt was in } 100 \text { g containers with identical labels. The yogurts were } \\
\text { similar in taste but one yogurt was thinner in texture. Participants were only }\end{array}$ \\
\hline
\end{tabular}


Fox 2015 (Continued)

shown the yogurt they were going to use and did not have the opportunity to make a comparison"

Patients/parents recorded diarrhea events and AE in diary

Participants and parents were blind

Incomplete outcome data Low risk (attrition bias)

All outcomes
Two out of 72 randomized patients were lost to follow-up It was not clear from which group they were. However the LTFU number was small and the event spread large

LTFU would not significantly affect the diarrhea outcome in a material way

LTFU would not significantly affect the composite AE outcome

\begin{tabular}{|c|c|c|}
\hline $\begin{array}{l}\text { Selective reporting (re- } \\
\text { porting bias) }\end{array}$ & Low risk & $\begin{array}{l}\text { Trial was prospectively registered } \\
\text { Australian New Zealand Clinical Trials Registry ACTRN12609000281291 }\end{array}$ \\
\hline
\end{tabular}

The outcomes listed of stool frequency and consistency are compatible with reported outcomes

\begin{tabular}{ll}
\hline Other bias $\quad$ Low risk & $\begin{array}{l}\text { The study was supported by Parmalat Australia who had no role in the formu- } \\
\text { lation or conduct of the study or in the data analysis or interpretation }\end{array}$
\end{tabular}

Georgieva 2015

\begin{tabular}{ll} 
Methods & Randomized, double-blind trial \\
& Withdrawals/Loss to follow-up: $3(3 \%)$ \\
& ITT: No \\
& Period of follow-up: 21 days following end of antibiotic treatment \\
\hline Participants & Diagnosis: 97 participants were described the diagnosis. Infections of respiratory $(n=42)(43.3 \%)$, gas- \\
& trointestinal, liver, pancreas infection $(n=23)(23.7 \%)$, eyes, nose, throat infection $(n=16)(16.5 \%)$, uri- \\
& nary tracts infections $(8)(8.2)$, others $(n=8)(8.2 \%)$ \\
& Country: Bulgaria \\
& Setting: hospital admitted patients \\
& Age: $3-12$ years mean 8.85 years
\end{tabular}

Interventions Probiotics: 100 million CFUs per day Lactobacillus reuteri DSM 17938

Antibiotics: Amikacin $(n=1)$, Cefazoline $(n=38)$, Cefotaxime $(n=1)$, Ceftriaxon $(n=41)$, Cefuroxime $(n=$ 4), Levofloxacin ( $n=1)$, Metronidazol $(n=3)$, Piperacillin $(n=7)$

\begin{tabular}{ll}
\hline Outcomes & ID: Control $1(2.1 \%)$ versus Treatment $1(2.04 \%)$ \\
& $\begin{array}{l}\text { Definition of diarrhea: An episode of diarrhoea was defined as three or more }(\geq 3) \text { soft and unformed or } \\
\text { watery bowel movements per day for at least } 48 \text { hours }\end{array}$
\end{tabular}

\section{Risk of bias}


Georgieva 2015 (Continued)

\begin{tabular}{|c|c|c|}
\hline Bias & Authors' judgement & Support for judgement \\
\hline $\begin{array}{l}\text { Random sequence genera- } \\
\text { tion (selection bias) }\end{array}$ & Low risk & "Computer generated randomization list of case numbers" \\
\hline \multirow[t]{2}{*}{$\begin{array}{l}\text { Allocation concealment } \\
\text { (selection bias) }\end{array}$} & Low risk & $\begin{array}{l}\text { Participants entered consecutively starting with the lowest case number in } \\
\text { each stratum }\end{array}$ \\
\hline & & $\begin{array}{l}\text { Randomisation and labelling of the test-samples were made by an indepen- } \\
\text { dent physician }\end{array}$ \\
\hline \multirow{3}{*}{$\begin{array}{l}\text { Blinding (performance } \\
\text { bias and detection bias) } \\
\text { All outcomes }\end{array}$} & Low risk & Study described as double blind \\
\hline & & $\begin{array}{l}\text { Diarrhea-diary/and Bristol scale filled out by parents/children both of whom } \\
\text { were blind }\end{array}$ \\
\hline & & $\begin{array}{l}\text { AE- It appears GSRS symptom score filled out by parents/children or study } \\
\text { physicians both of whom were blind }\end{array}$ \\
\hline $\begin{array}{l}\text { Incomplete outcome data } \\
\text { (attrition bias) } \\
\text { All outcomes }\end{array}$ & Unclear risk & $\begin{array}{l}\text { Diarrhea - 3\% missing outcome data It is unclear which group they were from. } \\
\text { While the total number missing is low the total number of diarrhea events was } \\
\text { also low. The missing outcome data could bias the results in a material way. } \\
\text { AE-Based on their reported results there were no reported AE although they } \\
\text { also report GSRS symptom scale. We were not able to reach the authors to } \\
\text { clarify this. Assuming no AE than even the low missing outcome data could } \\
\text { materially bias the results for this outcome }\end{array}$ \\
\hline
\end{tabular}

\begin{tabular}{lll}
\hline $\begin{array}{l}\text { Selective reporting (re- } \\
\text { porting bias) }\end{array}$ & Low risk & $\begin{array}{l}\text { The outcomes of the full text is the same as a priori listed in clinicaltrials.gov } \\
\text { (NCT01295918) }\end{array}$ \\
\hline Other bias & High risk & The clinical trial has been supported by a grant from BioGaya AB, Sweden \\
\hline
\end{tabular}

\section{Jindal 2017}

$\begin{array}{ll}\text { Methods } & \text { A randomized, open, parallel group study } \\ \text { Withdrawals/Loss to follow-up: } 0 \\ \text { ITT: N/A } \\ \text { Period of follow-up: } 14 \text { days after the start of an antibiotic }\end{array}$

\begin{tabular}{|c|c|}
\hline \multirow[t]{5}{*}{ Participants } & $N=600$ \\
\hline & Diagnosis: Tonsillitis, otitis, UTI \\
\hline & Country: India \\
\hline & Setting: Outpatient department of tertiary hospital \\
\hline & Age: 6 months to 12 years \\
\hline
\end{tabular}

Probiotics: Saccharomyces boulardii, 2-3 billion CFUs twice a day
Antibiotics: Co-amoxyclav, Cefpodoxime, Cefdinir, Cefixime, Cephalexin

Outcomes

ID: 16 in treatment group (16/300, 5.3\%), 72 in control group (72/300, 24\%) 


\begin{tabular}{|c|c|c|}
\hline Notes & Funding: Unfunded & \\
\hline \multicolumn{3}{|l|}{ Risk of bias } \\
\hline Bias & Authors' judgement & Support for judgement \\
\hline $\begin{array}{l}\text { Random sequence genera- } \\
\text { tion (selection bias) }\end{array}$ & Unclear risk & $\begin{array}{l}\text { Mentioned randomization but otherwise not described: "Children were ran- } \\
\text { domly divided into two groups" }\end{array}$ \\
\hline $\begin{array}{l}\text { Allocation concealment } \\
\text { (selection bias) }\end{array}$ & Unclear risk & $\begin{array}{l}\text { No information available regarding the method to conceal allocation se- } \\
\text { quence" }\end{array}$ \\
\hline $\begin{array}{l}\text { Blinding (performance } \\
\text { bias and detection bias) } \\
\text { All outcomes }\end{array}$ & High risk & Blinding was not done: "A randomized, open, parallel study was conducted" \\
\hline $\begin{array}{l}\text { Incomplete outcome data } \\
\text { (attrition bias) } \\
\text { All outcomes }\end{array}$ & Low risk & $\begin{array}{l}\text { All participants completed the study. } 600 \text { were eligible, and } 600 \text { completed the } \\
\text { study }\end{array}$ \\
\hline $\begin{array}{l}\text { Selective reporting (re- } \\
\text { porting bias) }\end{array}$ & Unclear risk & There is no published protocol for assessing reporting bias \\
\hline Other bias & Low risk & $\begin{array}{l}\text { The study was funded by the author. There was no other declared conflict of } \\
\text { interest }\end{array}$ \\
\hline
\end{tabular}

Jirapinyo 2002

\begin{tabular}{ll}
\hline Methods & $\begin{array}{l}\text { Randomized, placebo-controlled, double-blinded } \\
\text { Withdrawals/loss to follow-up: } 0 \text { participants } \\
\text { ITT: Not applicable } \\
\text { Period of follow-up: Not provided }\end{array}$ \\
\hline Participants & $\begin{array}{l}\text { N }=18 \text { enrolled } \\
\text { Diagnosis (Meningitis and/or Sepsis) } \\
\text { Country: Thailand } \\
\text { Setting: Single-site hospital inpatients } \\
\text { Age: } 1 \text { to } 36 \text { months }\end{array}$ \\
\hline Interventions & $\begin{array}{l}\text { Probiotics: LA, BI (1 capsule orally TID for } 7 \text { days, } 6 \text { billion CFUs per day), } \\
\text { Antibiotic: cefprozil } n=16, \text { ampicillin } n=4, \text { gentamycin } n=2, \text { cloxacillin } n=1\end{array}$ \\
\hline Outcomes & ID (treatment 37.5\% versus placebo $80 \%)$ \\
Definition of diarrhea: Not reported
\end{tabular}

\section{Risk of bias}

\begin{tabular}{lll}
\hline Bias & Authors' judgement & Support for judgement \\
\hline $\begin{array}{l}\text { Random sequence genera- } \\
\text { tion (selection bias) }\end{array}$ & Unclear risk & Based on a randomization list. Unclear how that was generated \\
\hline
\end{tabular}


Jirapinyo 2002 (Continued)

\begin{tabular}{l}
$\begin{array}{l}\text { Allocation concealment } \\
\text { (selection bias) }\end{array}$ \\
\hline
\end{tabular}

Blinding (performance Unclear risk Described as "double blind" without further details

bias and detection bias)

All outcomes

\begin{tabular}{|c|c|c|}
\hline $\begin{array}{l}\text { Incomplete outcome data } \\
\text { (attrition bias) } \\
\text { All outcomes }\end{array}$ & Unclear risk & $\begin{array}{l}\text { There were no mentions of drop outs. There was mention of } 3 \text { cases of sep- } \\
\text { sis. There was also mention that cases where probiotics sepsis was possible } \\
\text { would result in unblinding although it wasn't clear if those three were unblind- } \\
\text { ed. There was no statistical analysis as well }\end{array}$ \\
\hline
\end{tabular}

Selective reporting (re- Unclear risk
porting bias)
There is no definition mentioned of diarrhoea. In the methods section they mentioned the "characteristics and frequency" of stools would be observed. In the results section the number of patients with diarrhoea and days of di- arrhoea were noted. It is unclear what characteristics means and why they weren't reported

\begin{tabular}{ll}
\hline Other bias $\quad$ Unclear risk $\quad$ No mention of funding source \\
\hline
\end{tabular}

\section{King 2010}

Randomized, double-blind, placebo controlled trial
Withdrawals/Loss to follow-up: $13 / 28(46 \%)$
ITT: No
Period of follow-up: not reported

\begin{tabular}{|c|c|}
\hline \multirow[t]{5}{*}{ Participants } & $N=28$ \\
\hline & $\begin{array}{l}\text { Diagnosis: Pneunonia, RSV, seizure, acute respiratory failure, cardiac arrest, meningitis, sepsis/bac } \\
\text { teremia, altered mental status/water intoxication, neutropenia, renal failure }\end{array}$ \\
\hline & Country: United States \\
\hline & Setting: PICU (Pediatric Intensive Care Unit) \\
\hline & Age: 21 days- 11 years old \\
\hline
\end{tabular}

Interventions

Probiotics: Lactobacillus GG, 30 billion CFUs/day

Antibiotics: Cephalosporins, clindamycin, vancomycin, other (not specified)

Outcomes ID: 3 in treatment (3/8, 37.5\%), 4 in control (4/7, 57.1\%)

Definitions of diarrhea: More than 3 loose stools in 24 hours

\begin{tabular}{lll}
\hline Notes & Funding: Not reported \\
\hline Risk of bias & \\
\hline Bias & Authors' judgement & Support for judgement \\
\hline $\begin{array}{l}\text { Random sequence genera- } \\
\text { tion (selection bias) }\end{array}$ & Unclear risk & Not specified besides "randomization occurs a priori" \\
\hline
\end{tabular}


King 2010 (Continued) $\begin{array}{ll}\begin{array}{l}\text { Allocation concealment } \\ \text { (selection bias) }\end{array} & \begin{array}{l}\text { Not detailed beyond "a patient identification number is assigned by pharmacy } \\ \text { personnel" }\end{array}\end{array}$

Blinding (performance Low risk

bias and detection bias)

All outcomes
The author reported that the study was "double-blinded, placebo-controlled" and noted that a "matching capsule" was used

\begin{tabular}{lll}
\hline $\begin{array}{l}\text { Incomplete outcome data } \\
\text { (attrition bias) } \\
\text { All outcomes }\end{array}$ & High risk & Significant attrition: 13 participants either withdrew or were lost to follow-up \\
\hline $\begin{array}{l}\text { Selective reporting (re- } \\
\text { porting bias) }\end{array}$ & Unclear risk & At the time of review, this was an abstract only. There is no published protocol \\
\hline Other bias & Unclear risk & Not reported but noted they had no disclosures
\end{tabular}

Kodadad 2013

Randomized, placebo-controlled study, double-blinded
Withdrawals/Loss-to-follow-up: $0(0 \%)$
ITT: Not reported
Period of follow-up: 7 days (duration of antibiotics and probiotics)

\begin{tabular}{|c|c|c|}
\hline \multirow[t]{5}{*}{ Participants } & \multicolumn{2}{|l|}{$N=66$} \\
\hline & \multicolumn{2}{|l|}{ Diagnosis: H.pylori } \\
\hline & \multicolumn{2}{|l|}{ Country: Iran } \\
\hline & \multicolumn{2}{|c|}{ Setting: multiple, children's medical center } \\
\hline & \multicolumn{2}{|c|}{ Age: range 3 to 14 years mean 9.09 years } \\
\hline \multirow[t]{2}{*}{ Interventions } & \multicolumn{2}{|c|}{$\begin{array}{l}\text { Probiotics: } 1 \text { billion CFUs/1 sachet per day of combination of following species: Lactobacillus aci- } \\
\text { dophilus, Lactobacillus rhamnosus, Lactobacillus bulgaricus, Lactobacillus casei, Streptococcus ther- } \\
\text { mophilus, Bifidobacterium infantis and Bifidobacterium breve }\end{array}$} \\
\hline & \multicolumn{2}{|c|}{$\begin{array}{l}\text { Antibiotics: Oral amoxicillin } 50 \mathrm{mg} / \mathrm{kg} / \text { day twice daily; oral furazolidone } 6 \mathrm{mg} / \mathrm{kg} / \text { day twice daily, oral } \\
\text { omeprazole } 1 \mathrm{mg} / \mathrm{kg} / \text { day (duration: } 4 \text { weeks) }\end{array}$} \\
\hline \multirow[t]{2}{*}{ Outcomes } & \multicolumn{2}{|c|}{ ID: Control 8 (24.24\%) versus Treatment 2 (6.06\%) } \\
\hline & \multicolumn{2}{|c|}{ Definition of diarrhea: NS } \\
\hline Notes & \multicolumn{2}{|l|}{ Funding: NS } \\
\hline \multicolumn{3}{|l|}{ Risk of bias } \\
\hline Bias & Authors' judgement & Support for judgement \\
\hline $\begin{array}{l}\text { Random sequence genera- } \\
\text { tion (selection bias) }\end{array}$ & Unclear risk & "Randomized," however researchers did not explain further \\
\hline
\end{tabular}


Kodadad 2013 (Continued)

\begin{tabular}{|c|c|c|}
\hline $\begin{array}{l}\text { Allocation concealment } \\
\text { (selection bias) }\end{array}$ & Unclear risk & Not enough information provided \\
\hline $\begin{array}{l}\text { Blinding (performance } \\
\text { bias and detection bias) } \\
\text { All outcomes }\end{array}$ & Low risk & $\begin{array}{l}\text { Diarrhea and other AE were reported by parents and patients both of whom } \\
\text { were blinded }\end{array}$ \\
\hline $\begin{array}{l}\text { Incomplete outcome data } \\
\text { (attrition bias) } \\
\text { All outcomes }\end{array}$ & Low risk & No missing outcome data \\
\hline $\begin{array}{l}\text { Selective reporting (re- } \\
\text { porting bias) }\end{array}$ & Low risk & $\begin{array}{l}\text { Outcomes reported in line with outcomes set a priori on register (Iranian Reg- } \\
\text { istry of Clinical Trials: IRCT201201218793N1) }\end{array}$ \\
\hline Other bias & Low risk & Based on registry info it is sponsored by the university of Tehran \\
\hline
\end{tabular}

Kolodziej 2018

\begin{tabular}{ll} 
Methods & Randomized, placebo-controlled study, triple-blind trial \\
& Withdrawals/Loss to follow-up: $2 / 125$ in treatment group (1.6\%), $1 / 125$ in control group (0.8\%) \\
ITT: Yes & Period of follow-up: 7 days after the end of antibiotics and probiotics/placebo \\
\hline Participants & Children younger than 18 years who received antibiotic therapy within 24 hours of enrollment \\
\hline Interventions & Lactobacillus reuteri DSM 17938 \\
\hline Outcomes & $\begin{array}{l}\text { Incidence of diarrhea and AAD; frequencies of infectious diarrhea; need for discontinuation of antibiot- } \\
\text { ic treatment; need for hospitalization to manage diarrhea (in outpatients); need for intravenous rehy- } \\
\text { dration in any of the study groups;adverse events }\end{array}$ \\
\hline Notes & $\begin{array}{l}\text { The study was funded by the Medical University of Warsaw with study products being provided by Bio- } \\
\text { Gaia }\end{array}$ \\
\hline
\end{tabular}

\section{Risk of bias}

\begin{tabular}{lll}
\hline Bias & Authors' judgement & Support for judgement \\
\hline $\begin{array}{l}\text { Random sequence genera- } \\
\text { tion (selection bias) }\end{array}$ & Low risk & $\begin{array}{l}\text { "A computer-generated randomization list was prepared by a person unrelat- } \\
\text { ed to the trial" }\end{array}$ \\
\hline $\begin{array}{l}\text { Allocation concealment } \\
\text { (selection bias) }\end{array}$ & Low risk & $\begin{array}{l}\text { "Sequentially numbered, sealed, opaque envelopes containing the treatment } \\
\text { assignment...were concealed from the enrolling physicians" }\end{array}$ \\
\hline $\begin{array}{l}\text { Blinding (performance } \\
\text { bias and detection bias) }\end{array}$ & Low risk & $\begin{array}{l}\text { "All the investigators, caregivers, outcome assessors, and the person respon- } \\
\text { sible for the statistical analysis remained blinded until the completion of the } \\
\text { study" }\end{array}$ \\
\hline $\begin{array}{l}\text { Incomplete outcome data } \\
\text { (attrition bias) }\end{array}$ & Low risk & $\begin{array}{l}\text { The number of participants lost to follow-up is low }(1.2 \%, 3 / 250): 2 \text { in treat- } \\
\text { ment group and } 1 \text { in control group }\end{array}$ \\
\hline
\end{tabular}


Kolodziej 2018 (Continued)

Selective reporting (re- Low risk According to the protocol published in 2016, the author has reported all the reporting bias) sults

Other bias Low risk

The study was funded by the Medical University of Warsaw. The author has no conflict of interests

\section{Kotowska 2005}

$\begin{array}{ll}\text { Methods } & \text { Randomized, placebo-controlled, double-blinded. } \\ \text { Withdrawals/loss to follow-up: } 23 \text { participants (8.5\%) } \\ \text { ITT: Yes } \\ \text { Period of follow-up: } 2 \text { weeks after the end of antibiotic treatment }\end{array}$

\begin{tabular}{|c|c|}
\hline Participants & $\begin{array}{l}N=269 \text { enrolled } \\
\text { Diagnosis: (Bronchitis } n=64 \text {, Otitis media } n=79 \text {, Pneumonia } n=62 \text {, Tonsillitis } n=58 \text {, other RTIs } n=6 \text { ) } \\
\text { Country: Poland } \\
\text { Setting: Three teaching hospitals ( } n=72 \text { ) and two out-patient clinics }(n=197) \\
\text { Age: } 6.2 \text { to } 182 \text { months ( } 5 \text { months to } 15 \text { years) }\end{array}$ \\
\hline Interventions & $\begin{array}{l}\text { Probiotic: SB }(10 \text { billion CFUs/day for duration of antibiotic treatment [range } 7 \text { to } 9 \text { days] } \\
\text { Antibiotics: cefuroxime axetil }=72 \text {, amoxicillin clavulanate }=46 \text {, amoxicillin }=33 \text {, cefuroxime }(\mathrm{IV})=39 \text {, } \\
\text { penicillin }=33 \text {, clarithromycin }=20 \text {, roxithromycin }=13 \text {, other }=13\end{array}$ \\
\hline Outcomes & $\begin{array}{l}\text { ID (treatment } 7.5 \% \text { versus placebo } 23 \% \text { ) } \\
\text { Definition of diarrhea: Greater than or equal to } 3 \text { loose or watery stools/day for a minimum of } 48 \text { hours, } \\
\text { occurring during and/or up to } 2 \text { weeks after the end of antibiotic treatment }\end{array}$ \\
\hline Notes & Funding $=$ Not reported \\
\hline
\end{tabular}

\section{Risk of bias}

\begin{tabular}{|c|c|c|}
\hline Bias & Authors' judgement & Support for judgement \\
\hline $\begin{array}{l}\text { Random sequence genera- } \\
\text { tion (selection bias) }\end{array}$ & Low risk & Computer generated \\
\hline $\begin{array}{l}\text { Allocation concealment } \\
\text { (selection bias) }\end{array}$ & Low risk & $\begin{array}{l}\text { To ensure allocation concealment, an independent subject prepared the ran- } \\
\text { domization schedule and oversaw the packaging and labelling of trial treat- } \\
\text { ments }\end{array}$ \\
\hline $\begin{array}{l}\text { Blinding (performance } \\
\text { bias and detection bias) } \\
\text { All outcomes }\end{array}$ & Low risk & $\begin{array}{l}\text { Double-blind: All investigators, participants, outcome assessors and data ana- } \\
\text { lysts were blinded to the assigned treatment throughout the study }\end{array}$ \\
\hline $\begin{array}{l}\text { Incomplete outcome data } \\
\text { (attrition bias) } \\
\text { All outcomes }\end{array}$ & Low risk & $\begin{array}{l}<10 \% \text { dropout/lost to follow-up. Dropouts balanced in numbers across inter- } \\
\text { vention groups with similar reasons for missing data across groups. Addition- } \\
\text { ally the authors conducted extreme case scenarios }\end{array}$ \\
\hline $\begin{array}{l}\text { Selective reporting (re- } \\
\text { porting bias) }\end{array}$ & Unclear risk & Not reported. No protocol and register information \\
\hline Other bias & Unclear risk & No mention of funding \\
\hline
\end{tabular}


LaRosa 2003

\begin{tabular}{|c|c|}
\hline Methods & $\begin{array}{l}\text { Randomized, placebo-controlled, double-blinded. } \\
\text { Withdrawals/loss to follow-up: } 22 \text { participants }(18.3 \%) \\
\text { ITT: Yes } \\
\text { Period of follow-up: Not provided }\end{array}$ \\
\hline Participants & $\begin{array}{l}\mathrm{N}=120 \text { enrolled } \\
\text { Diagnosis: (Pharangitis } \mathrm{n}=48 \text {, Tonsillitis } \mathrm{n}=46 \text {, Otitis } \mathrm{n}=22 \text {, Bronchitis } \mathrm{n}=18 \text {, Other } \mathrm{n}=10 \text { [note some } \\
\text { children had more than one infection]) } \\
\text { Country: Italy } \\
\text { Setting: } \text { multi-centered } \\
\text { Age: } \text { mean } 6.6 \text { years }\end{array}$ \\
\hline Interventions & $\begin{array}{l}\text { Probiotic: LS ( } 5.5 \text { billion CFUs/day) with Prebiotic: FOS ( } 250 \text { mg/day) for } 10 \text { days) } \\
\text { Antibiotics: mixture, NS }\end{array}$ \\
\hline Notes & Funding $=$ Not reported \\
\hline
\end{tabular}

\section{Risk of bias}

\begin{tabular}{lll}
\hline Bias & Authors' judgement & Support for judgement \\
\hline $\begin{array}{l}\text { Random sequence genera- } \\
\text { tion (selection bias) }\end{array}$ & Low risk & Computer generated \\
\hline $\begin{array}{l}\text { Allocation concealment } \\
\text { (selection bias) }\end{array}$ & Low risk & $\begin{array}{l}\text { Each patient was given a code. The treatment package corresponded with the } \\
\text { code }\end{array}$ \\
\hline $\begin{array}{l}\text { Blinding (performance } \\
\text { bias and detection bias) } \\
\text { All outcomes }\end{array}$ & Low risk & Double-blind, identical placebo \\
\hline $\begin{array}{l}\text { Incomplete outcome data } \\
\text { (attrition bias) } \\
\text { All outcomes }\end{array}$ & Low risk & $\begin{array}{l}\text { Dropouts balanced in numbers across intervention groups with similar rea- } \\
\text { sons for missing data across groups }\end{array}$ \\
\hline $\begin{array}{l}\text { Selective reporting (re- } \\
\text { porting bias) }\end{array}$ & High risk & $\begin{array}{l}\text { Methods section indicate "condizioni generale" [general condition], but out- } \\
\text { come not reported }\end{array}$ \\
\hline \begin{tabular}{l} 
Other bias \\
\hline
\end{tabular} & Low risk & \begin{tabular}{l} 
The study appears to be free of other sources of bias \\
\hline
\end{tabular}
\end{tabular}

\section{Merenstein 2009}

\begin{tabular}{ll}
\hline Methods & Randomized, placebo controlled, double-blinded \\
& Withdrawal/loss to follow-up: 8 participants (6.4\%) \\
ITT: no & Period of follow-up: 15 days \\
\hline Participants & $\mathrm{N}=125$ \\
Diagnosis: URI
\end{tabular}


Merenstein 2009 (Continued)

Country: USA

Setting: primary care office

Age: 2.9 years treatment and 3.2 years control

Interventions Probiotics: LL, LP, LR, LC, LL subspecies diacetylactis, Leuconostoc cremoris, Bifidobacterium longum,
$\mathrm{BB}, \mathrm{LA}, \mathrm{SF}$ (at least half of a $150 \mathrm{ml}$ drink containing 7 to 10 billion CFUs bacteria and yeast/day)

Antibiotics: NS

\begin{tabular}{ll}
\hline Outcomes & ID: $18.0 \%$ treatment versus $21.9 \%$ control \\
& Definition of diarrhea: NS \\
\hline Notes & Funding: Industry (medication and operations) \\
\hline
\end{tabular}

\section{Risk of bias}

\begin{tabular}{|c|c|c|}
\hline Bias & Authors' judgement & Support for judgement \\
\hline $\begin{array}{l}\text { Random sequence genera- } \\
\text { tion (selection bias) }\end{array}$ & Unclear risk & $\begin{array}{l}\text { The randomization scheme was generated using permuted blocks with block } \\
\text { size equal to } 8\end{array}$ \\
\hline $\begin{array}{l}\text { Allocation concealment } \\
\text { (selection bias) }\end{array}$ & Unclear risk & Not described \\
\hline $\begin{array}{l}\text { Blinding (performance } \\
\text { bias and detection bias) } \\
\text { All outcomes }\end{array}$ & Low risk & $\begin{array}{l}\text { Double blind: "All research personnel and statisticians were blinded through- } \\
\text { out the study, including during initial review of data." A matching placebo was } \\
\text { used }\end{array}$ \\
\hline $\begin{array}{l}\text { Incomplete outcome data } \\
\text { (attrition bias) } \\
\text { All outcomes }\end{array}$ & Low risk & $\begin{array}{l}\text { "Loss to follow-up was exceptionally low. Only } 4 \text { participants in each group } \\
\text { were unable to be contacted at the final follow-up on day } 15 \text { " }\end{array}$ \\
\hline $\begin{array}{l}\text { Selective reporting (re- } \\
\text { porting bias) }\end{array}$ & Low risk & Outcomes identical to that reported in clinicaltrials.gov (NCT00481507) \\
\hline Other bias & Low risk & $\begin{array}{l}\text { Lifeway foods provided drink and funding although no author was associated } \\
\text { with the company }\end{array}$ \\
\hline
\end{tabular}

\section{Olek 2017}

\begin{tabular}{ll} 
Methods & Randomized, double-blind, placebo-controlled, multicenter trial \\
& Withdrawal/Loss to follow-up: $9 / 447(2 \%)$ \\
& ITT: N/A \\
& Period of follow-up: 14 days following end of antibiotic treatment \\
\hline Participants & Diagnosis: Respiratory tract infection $(n=217,49.5 \%)$, throat infection $(n=149,34 \%)$, ear infection $(n=$ \\
& $57,13 \%)$ and urinary tract infection $(n=11,2.5 \%)$ \\
Country: Poland & Setting: Outpatient, 13 primary healthcare centers
\end{tabular}


Age: 1 -11 years, mean $5.2 \pm 2.7$ years

Probiotics: Lactobacillus plantarum DSM $9843($ LP299V) 10 billion CFUs per day
Antibiotics: Penicillins $(n=186)$, cephalosporins $(n=118)$, sulfamethoxazole and trimethoprim ( $n=32)$,
macrolides $(n=101)$

ID: Treatment $85(39 \%)$, control $98(44.5 \%)$
Incidence of AAD: Treatment $6(2.8 \%)$, control $9(4.1 \%)$,
Definition of diarrhea: At least 1 loose/watery stool (Bristol Stool Chart - Type 6-7)
Definition of AAD: Three or more $(\geq 3)$ loose/watery stools per day starting 2 hours after initiation of an-
tibiotic treatment until the end of the study
AE: In total, 155 adverse events in 99 children were reported by parents. Placebo vs LP299V: $27.3 \%$ vs
17.9\%. No serious adverse events reported in the study.

\begin{tabular}{ll}
\hline Notes & Funding: The study was supported by Probi AB Solvegatan. I.A., N.L., and G.O. are employed by Probi \\
AB. A.O. is managing director of CRO (MEDICAL NETWORK) contracted for conducting this study. M.W. \\
and J.K. are co-owners of CRO (MEDICAL NETWORK) contracted for conducting this study
\end{tabular}

\section{Risk of bias}

\begin{tabular}{|c|c|c|}
\hline Bias & Authors' judgement & Support for judgement \\
\hline $\begin{array}{l}\text { Random sequence genera- } \\
\text { tion (selection bias) }\end{array}$ & Low risk & $\begin{array}{l}\text { "The randomization list used for the labelling and allocation of the study prod- } \\
\text { uct was generated using SAS Proc v9.1." "1:1 randomization in blocks of } 4 \text { " }\end{array}$ \\
\hline $\begin{array}{l}\text { Allocation concealment } \\
\text { (selection bias) }\end{array}$ & Low risk & $\begin{array}{l}\text { "The boxes containing LP299V/placebo were numbered, and the lowest avail- } \\
\text { able number at the study site was assigned by the investigator to a patient re- } \\
\text { cruited into the study" }\end{array}$ \\
\hline \multirow[t]{2}{*}{$\begin{array}{l}\text { Blinding (performance } \\
\text { bias and detection bias) } \\
\text { All outcomes }\end{array}$} & Low risk & $\begin{array}{l}\text { "The information about the allocation to specific study arm remained blind to } \\
\text { patients, parents, and all members of the study team including the investiga- } \\
\text { tors monitors, and data managers who assessed the study outcomes until all } \\
\text { data were collected and verified" }\end{array}$ \\
\hline & & $\begin{array}{l}\text { "Placebo capsules had the same appearance, texture and taste as those with } \\
\text { the active product" }\end{array}$ \\
\hline \multirow{2}{*}{$\begin{array}{l}\text { Incomplete outcome data } \\
\text { (attrition bias) } \\
\text { All outcomes }\end{array}$} & Low risk & $\begin{array}{l}\text { The number and reasons for those lost to follow-up }(n=9) \text { were described and } \\
\text { comparable across groups }\end{array}$ \\
\hline & & AEs have been reported \\
\hline $\begin{array}{l}\text { Selective reporting (re- } \\
\text { porting bias) }\end{array}$ & Low risk & $\begin{array}{l}\text { All outcomes have been reported based on the list on the clinical trials website } \\
\text { (NCT01940913) }\end{array}$ \\
\hline Other bias & High risk & $\begin{array}{l}\text { The study ws supported by Probi AB Solvegatan. Three authors (I.A., N.L., and } \\
\text { G.O.) are employed by Probi AB. A.O. is managing director of CRO (MEDICAL } \\
\text { NETWORK) contracted for conducting this study. M.W. and J.K. are co-owners } \\
\text { of CRO (MEDICAL NETWORK) contracted for conducting this study }\end{array}$ \\
\hline
\end{tabular}

Peng 2014

Methods Randomized according the random number table method 
Peng 2014 (Continued)

Withdrawal/Loss to follow-up: 0

ITT: N/A

Period of follow-up: Not provided

\begin{tabular}{ll}
\hline Participants & $\mathrm{N}=112$ \\
& Diagnosis: Newborns with pneumonia \\
& Country: China \\
& Setting: Inpatient \\
& Age: $3-28$ days (mean $11.5 \pm 4.2$ days) \\
\hline Interventions & Probiotics: Saccharomyces boulardii $250 \mathrm{mg}$ (5 billion CFUs) per day, twice a day \\
& Antibiotics: Not reported \\
\hline Outcomes & ID: Treatment 11 (19.6\%), control 30 (53.6\%) \\
& Definition of diarrhea: Increased bowel movements 72 hours after hospitalization to more than 3 times \\
a day, and with a change in stool consistency
\end{tabular}

\section{Risk of bias}

\begin{tabular}{lll}
\hline Bias & Authors' judgement & Support for judgement \\
\hline $\begin{array}{l}\text { Random sequence genera- } \\
\text { tion (selection bias) }\end{array}$ & Low risk & $\begin{array}{l}\text { The participants were divided into a treatment group and a control group ac- } \\
\text { cording to a random number table }\end{array}$ \\
\hline $\begin{array}{l}\text { Allocation concealment } \\
\text { (selection bias) }\end{array}$ & High risk & $\begin{array}{l}\text { Not described. However, the probiotic group received } 2 \text { medications and con- } \\
\text { trol group received } 1 \text { medication thus we determined that allocation was not } \\
\text { concealed }\end{array}$ \\
\hline
\end{tabular}

\begin{tabular}{|c|c|c|}
\hline $\begin{array}{l}\text { Blinding (performance } \\
\text { bias and detection bias) }\end{array}$ & High risk & $\begin{array}{l}\text { Not described. Unlikely to have been blinded. The treatment group was given } \\
\text { antibiotics and the control group was given antibiotics plus probiotics }\end{array}$ \\
\hline
\end{tabular}

All outcomes

\begin{tabular}{lll}
\hline $\begin{array}{l}\text { Incomplete outcome data } \\
\text { (attrition bias) } \\
\text { All outcomes }\end{array}$ & Low risk & $\begin{array}{l}\text { All participants completed the study. } 112 \text { neonates were included, and } 112 \\
\text { were analyzed }\end{array}$ \\
\hline $\begin{array}{l}\text { Selective reporting (re- } \\
\text { porting bias) }\end{array}$ & Unclear risk & There is no published protocol to provide this information \\
\hline $\begin{array}{ll}\text { Other bias } \\
\end{array}$ & Unclear risk & $\begin{array}{l}\text { The source of funding was not described } \\
\text { The diagnosis of diarrhea in neonates is very difficult because their stool is } \\
\text { usually loose or liquid and they have multiple bowel movements every day. } \\
\text { Newborns with } 7 \text { or } 8 \text { loose stools per day may still be considered "normal" }\end{array}$
\end{tabular}


Ruszczynski 2008 (Continued)

Withdrawals/loss to follow-up: 0

ITT: yes

Period of follow-up: two weeks following end of antibiotic treatment

\begin{tabular}{ll}
\hline Participants & N $=240$ \\
& Diagnosis: Otitis, URT, LRT, UTI, other \\
Country: Poland & Setting: Two hospitals and one private practice \\
& Age: treatment 4.6 years and control 4.5 years \\
\hline Interventions & Probiotics: Lactobacillus Rhamosus (strains E/N, Oxy and Pen) (40 billion CFUs bacteria/day) \\
& $\begin{array}{l}\text { Antibiotics: penicillins }=15, \text { broad spectrum penicillins }=119, \text { cephalosporins }=89, \text { macrolides }=15, \\
\text { clindamycin }=2\end{array}$ \\
\hline ID: (treatment $7.5 \%$ versus control $16.7 \%)$ \\
Definition of diarrhea: greater than or equal to 3 loose stools per day for a minimum of 48 hours, occur- \\
ring during and/or up to two weeks after the end of the antibiotic therapy
\end{tabular}

\section{Risk of bias}

\begin{tabular}{|c|c|c|}
\hline Bias & Authors' judgement & Support for judgement \\
\hline $\begin{array}{l}\text { Random sequence genera- } \\
\text { tion (selection bias) }\end{array}$ & Low risk & $\begin{array}{l}\text { Computer generated: Permuted block of six (three received placebo and three, } \\
\text { active treatment). Separate randomization lists were prepared for each site }\end{array}$ \\
\hline $\begin{array}{l}\text { Allocation concealment } \\
\text { (selection bias) }\end{array}$ & Low risk & $\begin{array}{l}\text { To ensure allocation concealment, an independent subject prepared the ran- } \\
\text { domization schedule and oversaw the packaging and labelling of trial treat- } \\
\text { ments }\end{array}$ \\
\hline $\begin{array}{l}\text { Blinding (performance } \\
\text { bias and detection bias) } \\
\text { All outcomes }\end{array}$ & Low risk & $\begin{array}{l}\text { All investigators, participants, outcome assessors and data analysts were } \\
\text { blinded to the assigned treatment throughout the study }\end{array}$ \\
\hline $\begin{array}{l}\text { Incomplete outcome data } \\
\text { (attrition bias) } \\
\text { All outcomes }\end{array}$ & Low risk & $\begin{array}{l}\text { Overall, three of the randomized children (one in the probiotic group and two } \\
\text { in the placebo group) discontinued the study intervention and started to use } \\
\text { one of the commercially available probiotics products. However, no patient } \\
\text { was lost to follow-up }\end{array}$ \\
\hline $\begin{array}{l}\text { Selective reporting (re- } \\
\text { porting bias) }\end{array}$ & Unclear risk & Not reported. No protocol and register information \\
\hline Other bias & Low risk & $\begin{array}{l}\text { Biomed provided the intervention but they "had no role in the conception, de- } \\
\text { sign, or conduct of the study or in the analysis or interpretation of the data" }\end{array}$ \\
\hline
\end{tabular}

Saneeyan 2011

Methods Randomized, placebo-controlled, patient blinded


Saneeyan 2011 (Continued)

Withdrawals/Loss to follow-up: None

ITT: None needed

Period of follow-up: NS

\begin{tabular}{|c|c|}
\hline \multirow[t]{5}{*}{ Participants } & $N=50$ \\
\hline & Diagnosis: H.pylori \\
\hline & Country: Iran \\
\hline & Setting: Community healthcare \\
\hline & Age: 4-14 mean 8.2 treatment group, 9.5 control group \\
\hline \multirow[t]{2}{*}{ Interventions } & $\begin{array}{l}\text { Probiotics: One sachet per day of } 1 \text { billion CFUs combined of following species: Lactobasillus casei, Lac- } \\
\text { tobacillus acidophilus, Lactobasillus reuteri, Lactobasillus bulgaricus, Streptococcus, Bifidobacterium bi- } \\
\text { fidum, Bifidobacterium infantis } \\
\text { Antibiotics: Amoxicillin } 25 \mathrm{mg} / \mathrm{kg} \text { BID (max dose is } 1.5 \text { grams per day), Clarithromycin } 10 \mathrm{mg} / \mathrm{kg} \text { BID } \\
\text { (max dose } 1 \text { gram per day) }\end{array}$ \\
\hline & Omeprazole 0.5 mg/kg BID (no max dose listed) \\
\hline
\end{tabular}

ID: 13 Control versus 3 Treatment
Definition of diarrhea: 3 times excretion per day or more, if it is loose or watery for at least 48 hours dur-
ing the therapy or two weeks after the antibiotic therapy

Notes Funding: grant from university, other sources NS

\section{Risk of bias}

\begin{tabular}{lll}
\hline Bias & Authors' judgement & Support for judgement \\
\hline $\begin{array}{l}\text { Random sequence genera- } \\
\text { tion (selection bias) }\end{array}$ & Low risk & Random sequence number table (random number generating) \\
\hline $\begin{array}{l}\text { Allocation concealment } \\
\text { (selection bias) }\end{array}$ & Unclear risk & Nothing mentioned \\
\hline $\begin{array}{l}\text { Blinding (performance } \\
\text { bias and detection bias) }\end{array}$ & Unclear risk & $\begin{array}{l}\text { Sachets (of probiotic and placebo) look the same. Nothing else listed about } \\
\text { blinding }\end{array}$ \\
\hline $\begin{array}{l}\text { Incomplete outcome data } \\
\text { (attrition bias) } \\
\text { All outcomes }\end{array}$ & Low risk & All participants completed the study \\
\hline $\begin{array}{l}\text { Selective reporting (re- } \\
\text { porting bias) }\end{array}$ & Unclear risk & $\begin{array}{l}\text { All outcomes listed in methods are reported in results. No registered protocol } \\
\text { could be found }\end{array}$ \\
\hline \begin{tabular}{l} 
Other bias \\
\hline
\end{tabular} & Unclear risk & No funding from industry or other sources mentioned \\
\hline
\end{tabular}

\section{Shan 2013}

\begin{tabular}{ll}
\hline Methods & Randomized open trial, nested observational \\
& Withdrawals/Loss to follow-up: 50 \\
\hline
\end{tabular}


Shan 2013 (Continued)

\section{ITT: No}

Period of follow-up: 2 weeks following end of antibiotic treatment

\begin{tabular}{ll}
\hline Participants & $\mathrm{N}=333$ \\
& Diagnosis: pneumonia, asthma, lower respiratory tract infection \\
Country: China & \\
& Setting: single site hospital \\
& Age: average 48 months \\
\hline Interventions & Probiotics: Saccharomyces boulardii $2 \times 250 \mathrm{mg}$ (10 billion CFUs/day) \\
& Antibiotics: cefepime, cefoperazone, sulbactam, cefuroxime, amoxicillin, clavulanic acid, erythromycin \\
\hline Outcomes & ID: Conrol 42 (29.2\%) versus treatment 11 (7.9\%) \\
& $\begin{array}{l}\text { Definition of diarrhea: } \geq 3 \text { loose or watery stools (BSS type 5, } 6 \text { and } 7) \text { per day during at least } 2 \text { days, oc- } \\
\text { curring during treatment and/ or up to } 2 \text { weeks after the antibiotic therapy had stopped. AAD was de- } \\
\text { fined as diarrhoea caused by C. difficile or diarrhoea with negative stool cultures }\end{array}$ \\
\hline Fotes & Funding: NS
\end{tabular}

\section{Risk of bias}

\begin{tabular}{|c|c|c|}
\hline Bias & Authors' judgement & Support for judgement \\
\hline $\begin{array}{l}\text { Random sequence genera- } \\
\text { tion (selection bias) }\end{array}$ & Low risk & $\begin{array}{l}\text { "Randomisation was done according to a computer-determined allocation to } \\
\text { group A or B" }\end{array}$ \\
\hline $\begin{array}{l}\text { Allocation concealment } \\
\text { (selection bias) }\end{array}$ & Low risk & $\begin{array}{l}\text { "The [randomization] sequence was concealed in an envelope, and the next } \\
\text { neutral envelope was opened each time the next patient was included in the } \\
\text { study" }\end{array}$ \\
\hline $\begin{array}{l}\text { Blinding (performance } \\
\text { bias and detection bias) } \\
\text { All outcomes }\end{array}$ & High risk & "This study was an open, randomised, controlled clinical trial" \\
\hline $\begin{array}{l}\text { Incomplete outcome data } \\
\text { (attrition bias) } \\
\text { All outcomes }\end{array}$ & High risk & $15 \%$ missing outcome data \\
\hline $\begin{array}{l}\text { Selective reporting (re- } \\
\text { porting bias) }\end{array}$ & Unclear risk & Not registered. No protocol \\
\hline Other bias & Unclear risk & $\begin{array}{l}\text { Funding source unclear. One of the authors is a consultant for a probiotics } \\
\text { company }\end{array}$ \\
\hline
\end{tabular}

Sykora 2005

$\begin{array}{ll}\text { Methods } & \text { Randomized, double-blind study } \\ & \text { Withdrawals/Loss to follow-up: } 6 \\ \text { ITT: Yes }\end{array}$


Sykora 2005 (Continued)

Period of follow-up: 4 weeks

Participants
Diagnosis: H.pylori
Country: Czech Republic
Setting: Hospital general care, 3 sites
Age: average 12.6 treatment, average 12.9 control

\begin{tabular}{ll}
\hline Interventions & Probiotics: Lactobacillus casei DN-114 001, A dose of $100 \mathrm{~mL}$ of containing 10 billion CFUs/day) \\
& Antibiotics: oral amoxicillin $25 \mathrm{mg} / \mathrm{kg}$, oral clarithromycin $7.5 \mathrm{mg} / \mathrm{kg}$, omeprazole $10 \mathrm{mg}$ (15-30 kg) or \\
& $20 \mathrm{mg}(30 \mathrm{~kg})$
\end{tabular}

Outcomes ID: Control 5 versus Treatment 3

Definition of diarrhea: not defined; data in adverse events

Notes Funding: Danone, Ministry of Health of Czech Republic

\section{Risk of bias}

\begin{tabular}{|c|c|c|}
\hline Bias & Authors' judgement & Support for judgement \\
\hline $\begin{array}{l}\text { Random sequence genera- } \\
\text { tion (selection bias) }\end{array}$ & Low risk & $\begin{array}{l}\text { "Randomization was performed using a computer generated randomization } \\
\text { list" }\end{array}$ \\
\hline $\begin{array}{l}\text { Allocation concealment } \\
\text { (selection bias) }\end{array}$ & Low risk & $\begin{array}{l}\text { "All children received their patient number in ascending order corresponding } \\
\text { to the order of inclusion. This number corresponded to a randomized medica- } \\
\text { tion scheme" }\end{array}$ \\
\hline $\begin{array}{l}\text { Blinding (performance } \\
\text { bias and detection bias) }\end{array}$ & Low risk & Double blind \\
\hline All outcomes & & $\begin{array}{l}\text { Diarrhea and AE reported by patients, parents, and study personnel all of } \\
\text { whom were blinded }\end{array}$ \\
\hline $\begin{array}{l}\text { Incomplete outcome data } \\
\text { (attrition bias) } \\
\text { All outcomes }\end{array}$ & Low risk & $\begin{array}{l}\text { The numbers and reasons for withdrawal/drop-outs were described and com- } \\
\text { parable across groups (and s approximately 10\%) }\end{array}$ \\
\hline $\begin{array}{l}\text { Selective reporting (re- } \\
\text { porting bias) }\end{array}$ & Unclear risk & $\begin{array}{l}\text { Not registered and no protocol published. The primary outcome of interest } \\
\text { was H pylori. However "patients and parents were asked to complete a stan- } \\
\text { dard questionnaire to assess the occurrence of prospectively defined adverse } \\
\text { events." AE which include our outcome diarrhea were identified a priori }\end{array}$ \\
\hline Other bias & Low risk & $\begin{array}{l}\text { Sponsor is acknowledged and no one from the sponsoring agency was an au- } \\
\text { thor }\end{array}$ \\
\hline
\end{tabular}

\section{Szajewska 2009}

Randomized, placebo controlled, double blind
Withdrawals/loss to follow-up: 17 (20.9\%)
ITT: yes


Szajewska 2009 (Continued)

Period of follow-up: 3 weeks ( 2 weeks after end of antibiotic treatment)

\begin{tabular}{|c|c|c|}
\hline \multirow[t]{5}{*}{ Participants } & \multicolumn{2}{|l|}{$N=83$} \\
\hline & \multicolumn{2}{|c|}{ Diagnosis: H. pylori infection } \\
\hline & \multicolumn{2}{|l|}{ Country: Poland } \\
\hline & \multicolumn{2}{|c|}{ Setting: hospitalized/inpatients } \\
\hline & \multicolumn{2}{|c|}{ Age: 12.3 years treatment and 11.9 years control } \\
\hline \multirow[t]{2}{*}{ Interventions } & \multicolumn{2}{|c|}{ Probiotics: Lactobacillus GG (1 billion CFUs/day) } \\
\hline & \multicolumn{2}{|c|}{$\begin{array}{l}\text { Antibiotics: all patients received amoxicillin and clarithromycin (all patients also received omeprazole } \\
\text { a proton pump inhibitor) }\end{array}$} \\
\hline \multirow[t]{2}{*}{ Outcomes } & \multicolumn{2}{|c|}{ ID: (6\% treatment versus $20 \%$ control) } \\
\hline & \multicolumn{2}{|c|}{$\begin{array}{l}\text { Definition of diarrhea: } 3 \text { or more loose or watery stools per day for a minimum of } 48 \text { hours occurring } \\
\text { during and/or up to } 2 \text { weeks after the end of antibiotic therapy }\end{array}$} \\
\hline Notes & \multicolumn{2}{|c|}{ Funding: Industry (medications) and Independent (Medical University of Warsaw) } \\
\hline \multicolumn{3}{|l|}{ Risk of bias } \\
\hline Bias & Authors' judgement & Support for judgement \\
\hline $\begin{array}{l}\text { Random sequence genera- } \\
\text { tion (selection bias) }\end{array}$ & Low risk & Computer generated \\
\hline $\begin{array}{l}\text { Allocation concealment } \\
\text { (selection bias) }\end{array}$ & Low risk & $\begin{array}{l}\text { LGG and the control product were packed in identical forms. Randomization } \\
\text { codes were secured until all of the data entry was complete }\end{array}$ \\
\hline $\begin{array}{l}\text { Blinding (performance } \\
\text { bias and detection bias) } \\
\text { All outcomes }\end{array}$ & Low risk & $\begin{array}{l}\text { All of the study personnel, patients, and personnel involved in the conduct of } \\
\text { the study were unaware of treatment assignments throughout the study }\end{array}$ \\
\hline $\begin{array}{l}\text { Incomplete outcome data } \\
\text { (attrition bias) } \\
\text { All outcomes }\end{array}$ & High risk & $\begin{array}{l}10 \text { drop outs versus } 7 \text { drop outs. Reasons why were given (no diary or UBT). Da- } \\
\text { ta was analyzed with opposite extremes of assumptions regarding those drop } \\
\text { outs for H. Pylori but not for side effects }\end{array}$ \\
\hline $\begin{array}{l}\text { Selective reporting (re- } \\
\text { porting bias) }\end{array}$ & Unclear risk & $\begin{array}{l}\text { Not registered. No protocol. All outcomes mentioned in methods section were } \\
\text { reported on in results section }\end{array}$ \\
\hline Other bias & Low risk & $\begin{array}{l}\text { Baseline characteristics are very close. Dicofarm supplied study product but } \\
\text { "had no role in the conception, design, or conduct of the study or in the analy- } \\
\text { sis or interpretation of data" }\end{array}$ \\
\hline
\end{tabular}

Szymanski 2008

Randomized, placebo controlled, double blind
Withdrawal/loss to follow-up: 0
ITT: yes

Period of follow-up: less than or equal to 4 weeks ( 2 weeks after end of antibiotic treatment) 
Szymanski 2008 (Continued)
Participants
$N=78$
Diagnosis: otitis media, respiratory tract infections, scarlet fever, other
Country: Poland
Setting: pediatric hospitals and outpatient clinics
Age: median age 7 years (range 1 to 15 years)

Interventions

Probiotics: Bifidobacterium longum PL03, LRKL53A, LP PL02 (200 million CFUs bacteria/day)

Antibiotics: amoxicillin $w /$ or $w /$ o clavulanate $=34$, cephalosporins $=20$, penicillin $=5$, acrolides $=18$, aminoglycosides $=1$

\begin{tabular}{ll}
\hline Outcomes & ID: $(2.5 \%$ treatment versus $5.3 \%$ control $)$ \\
& MSF: $(1.0+/-0.4$ treatment versus $1.3+/-0.6)$ \\
& $\begin{array}{l}\text { Definition of diarrhea: } 3 \text { or more loose or watery stools per day for a minimum of } 48 \text { hrs, occurring dur- } \\
\text { ing and/or up to } 2 \text { weeks after the end of the antibiotic therapy }\end{array}$ \\
\hline Notes & Funding: Industry (medications)
\end{tabular}

\section{Risk of bias}

\begin{tabular}{|c|c|c|}
\hline Bias & Authors' judgement & Support for judgement \\
\hline $\begin{array}{l}\text { Random sequence genera- } \\
\text { tion (selection bias) }\end{array}$ & Low risk & Computer generated \\
\hline $\begin{array}{l}\text { Allocation concealment } \\
\text { (selection bias) }\end{array}$ & Low risk & $\begin{array}{l}\text { To ensure allocation concealment, an independent person prepared the ran- } \\
\text { domization schedule and oversaw the packaging and labelling of the trial } \\
\text { treatments }\end{array}$ \\
\hline $\begin{array}{l}\text { Blinding (performance } \\
\text { bias and detection bias) } \\
\text { All outcomes }\end{array}$ & Low risk & $\begin{array}{l}\text { All study personnel and parents and guardians were unaware of the group as- } \\
\text { signments. Randomization codes were secured until all data entry was com- } \\
\text { plete }\end{array}$ \\
\hline $\begin{array}{l}\text { Incomplete outcome data } \\
\text { (attrition bias) } \\
\text { All outcomes }\end{array}$ & Low risk & $\begin{array}{l}\text { The analysis was based on the intention-to-treat principle, with all patients in- } \\
\text { cluded in their assigned group. No dropouts reported }\end{array}$ \\
\hline $\begin{array}{l}\text { Selective reporting (re- } \\
\text { porting bias) }\end{array}$ & Unclear risk & Not reported. No protocol and registered information \\
\hline Other bias & Unclear risk & $\begin{array}{l}\text { "The active treatment and placebo used in this study were prepared by IBSS } \\
\text { Biomed S.A., Cracow, Poland." No comment was offered with regards to IBSS } \\
\text { Biomed's role in study design, analysis }\end{array}$ \\
\hline
\end{tabular}

Tankanow 1990

$\begin{array}{ll}\text { Methods } & \text { Randomized, placebo-controlled, double-blinded. } \\ & \text { Withdrawals/loss to follow-up: } 22 \text { participants (36.6\%) } \\ \text { ITT: no } & \text { Period of follow-up: Not provided }\end{array}$


Tankanow 1990 (Continued)

$\mathrm{N}=60$ enrolled
Diagnosis: children with infections in which amoxicillin was reasonable therapy
Country: United States
Setting: Local pediatric practice during a 13 month period
Age: 5 months to 6 years (mean age $29+/-17$ months)

\begin{tabular}{ll}
\hline Interventions & $\begin{array}{l}\text { Probiotics: LA, LB ((1 gram packets ( } 500 \text { million per packet) } 4 \text { times per day equalling approximately } 2 \\
\text { billion CFUs/day) for } 5 \text { to } 12 \text { days } \\
\text { Antibiotics: amoxicillin only - dose based on clinician experience and manufactures dosing guidelines }\end{array}$ \\
\hline Outcomes & $\begin{array}{l}\text { ID (treatment } 66 \% \text { versus placebo } 69.5 \%) \\
\text { Definition of diarrhea: one or more abnormally loose bowel movements/day throughout the study pe- } \\
\text { riod of } 1 \text { to } 10 \text { days }\end{array}$ \\
\hline Notes & Funding = supported in full by Hynson, Westcott \& Dunning Products \\
\hline
\end{tabular}

\section{Risk of bias}

\begin{tabular}{lll}
\hline Bias & Authors' judgement & Support for judgement \\
\hline $\begin{array}{l}\text { Random sequence genera- } \\
\text { tion (selection bias) }\end{array}$ & Unclear risk & $\begin{array}{l}\text { Randomization provided by product manufacturer, otherwise unclear how } \\
\text { randomization was generated }\end{array}$ \\
\hline $\begin{array}{l}\text { Allocation concealment } \\
\text { (selection bias) }\end{array}$ & Unclear risk & Not described \\
\hline $\begin{array}{l}\text { Blinding (performance } \\
\text { bias and detection bias) }\end{array}$ & High risk & $\begin{array}{l}\text { Double-blind, otherwise not described. Blinding codes were held by manufac- } \\
\text { turer. One reason mentioned for subjects not continuing the study was "taste." } \\
\text { There was an imbalance of drop outs from groups. Could taste be different } \\
\text { for each intervention? Did this affect blinding on the side of the patient? It is } \\
\text { unclear how many dropped out for taste reasons }\end{array}$ \\
\hline $\begin{array}{l}\text { Incomplete outcome data } \\
\text { (attrition bias) } \\
\text { All outcomes }\end{array}$ & High risk & $\begin{array}{l}\text { There was a 37\% drop-out/ lost-to-follow-up. The final number of subjects } \\
\text { analyzed was not equal in magnitude (15 active, 23 placebo). The number of } \\
\text { subjects who didn't finish the study was high when compared to observed out- } \\
\text { comes (22 didn't finish, 26 cases of diarrhoea (10 in active, 16 in placebo)) }\end{array}$ \\
\hline $\begin{array}{l}\text { Selective reporting (re- } \\
\text { porting bias) }\end{array}$ & Unclear risk & $\begin{array}{l}\text { Not registered. No protocol. Outcomes mentioned in Methods section were } \\
\text { consistent to those mentioned in Results section }\end{array}$ \\
\hline $\begin{array}{l}\text { Other bias } \\
\text { Tigh risk }\end{array}$ & $\begin{array}{l}\text { Study was funded in full by manufacturer (i.e. provided product and placebo } \\
\text { and also provided the randomization and held the codes) }\end{array}$ \\
\hline
\end{tabular}

Vanderhoof 1999

\begin{tabular}{ll}
\hline Methods & Randomized, placebo-controlled, double-blinded. \\
& Withdrawals/loss to follow-up: 14 participants $(6.9 \%)$ \\
& ITT: no \\
& Period of follow-up: until antibiotic treatment was completed or diarrhea ceased \\
\hline Participants & $\mathrm{N}=202$ enrolled \\
& Diagnosis: for children with complete follow-up (Otitis $n=109$, Pharangitis $n=37$, Bronchitis $n=19$, \\
& Dermatological $n=11$, Sinusitis $n=10$, Other $n=2)$ \\
& Country: United States \\
& Setting: private pediatric practice \\
& Age 4 to 12 yrs (mean age 4 years)
\end{tabular}


Vanderhoof 1999 (Continued)

Interventions
Probiotics: L. GG (10 billion for children less than $12 \mathrm{~kg}$; 20 billion for greater than or equal to $12 \mathrm{~kg}$ for duration of antibiotic treatment ( 7 to 14 days)

Antibiotics: amoxicillin $n=65$, amoxicillin clavulanate $n=33$, cefprozil $n=13$, clarithromycin $n=18$, other $n=59$
ID (treatment $8 \%$ versus control 26\%)

$\operatorname{MDD}(4.7$ versus 5.9$)$

MSC (5.29 versus 5.04)

MSF (1.51 versus 1.59)

Definition of diarrhea: Greater than or equal to 2 liquid stools/day on $\geq 2$ occasions throughout the study period

\section{Risk of bias}

\begin{tabular}{lll}
\hline Bias & Authors' judgement & Support for judgement \\
\hline $\begin{array}{l}\text { Random sequence genera- } \\
\text { tion (selection bias) }\end{array}$ & Low risk & Randomized with a computer-generated randomization table \\
\hline $\begin{array}{l}\text { Allocation concealment } \\
\text { (selection bias) }\end{array}$ & Unclear risk & $\begin{array}{l}\text { Product randomization by blinded numeric } \\
\text { codes was performed by the supplier before the product was shipped to the in- } \\
\text { vestigation site. Codes were kept by the supplier until all data were collected }\end{array}$ \\
\hline $\begin{array}{l}\text { Blinding (performance } \\
\text { bias and detection bias) }\end{array}$ & Low risk & $\begin{array}{l}\text { The LGG and placebo were packed in identical bottles with identical capsule } \\
\text { covers." "Codes were kept by the supplier until all data were collected" }\end{array}$ \\
\hline $\begin{array}{l}\text { Incomplete outcome data } \\
\text { (attrition bias) } \\
\text { All outcomes }\end{array}$ & Low risk & $\begin{array}{l}\text { "The study was completed by 188 children (median age 4 years); 14 failed to } \\
\text { complete the study, primarily because of antibiotic noncompliance or inability } \\
\text { of the investigators to contact the primary caregiver at the assigned follow up } \\
\text { time. None of the participants failed to complete the 10-day course of antibi- } \\
\text { otics because of a change in stool consistency or frequency. There were no fail- } \\
\text { ures resulting from untoward effects of either LGG or placebo. Both active and } \\
\text { placebo groups were similar for age distribution, sex, and type of antibiotics, } \\
\text { and all who completed the study had no difficulty consuming the prescribed } \\
\text { amount" }\end{array}$
\end{tabular}

\begin{tabular}{lll}
\hline $\begin{array}{l}\text { Selective reporting (re- } \\
\text { porting bias) }\end{array}$ & Unclear risk & Not reported. No protocol and register information \\
\hline Other bias & Unclear risk & $\begin{array}{l}\text { Lead author is a consultant for CAG nutrition (division of ConAgra) which } \\
\text { makes the product }\end{array}$ \\
\hline
\end{tabular}

Wan 2017

\begin{tabular}{ll} 
Methods & Randomized study by means of random block allocation \\
& Withdrawal/loss to follow-up: None \\
ITT: N/A & Period of follow-up: 14 days after discontinuation of antibiotic therapy \\
\hline Participants & $\mathrm{N}=408$
\end{tabular}


Wan 2017 (Continued)

Diagnosis: Respiratory tract infection or pneumonia $(n=368)$; Pertussis $(n=6)$; Kawasaki Disease $(n=$

3); Urinary infection $(n=5)$; Scarlet fever $(n=1)$; Congenital syphilis $(n=1)$

Country: China

Setting: Inpatient

Age: 1 month-3 years (mean 1.14 years)

Interventions

Probiotics: Saccharomyces boulardii 250mg (5 billion CFUs) per day

Antibiotics: 1 to 2 antibiotics, type not specified

Outcomes ID: Treatment $5(2.3 \%)$, control, $32(16.4 \%)$

Definition of diarrhea: Increased stool frequency to at least twice a day, with change in stool consistency for more than 48 hours. Need to rule out rotavirus enteritis, bacterial dysentery and gastrointestinal infections such as food poisoning, and diarrhea caused by non-infectious causes such as inflammatory bowel disease and irritable bowel syndrome

Notes Funding: Not reported

\section{Risk of bias}

\begin{tabular}{lll}
\hline Bias & Authors' judgement & Support for judgement \\
\hline $\begin{array}{l}\text { Random sequence genera- } \\
\text { tion (selection bias) }\end{array}$ & Low risk & $\begin{array}{l}\text { "Children were randomly divided into control and prevention group by means } \\
\text { of block random allocation method" }\end{array}$ \\
\hline $\begin{array}{l}\text { Allocation concealment } \\
\text { (selection bias) }\end{array}$ & Low risk & Central allocation \\
\hline
\end{tabular}

Blinding (performance High risk Not described. Unlikely to be blinded. The treatment group was given antibiot-
bias and detection bias) All outcomes ic plus probiotic and the control group was given antibiotic and symptom-associated treatment

\begin{tabular}{lll}
$\begin{array}{l}\text { Incomplete outcome data } \\
\text { (attrition bias) } \\
\text { All outcomes }\end{array}$ & Low risk & No loss to follow-up: 408 included, 408 analyzed \\
\hline $\begin{array}{l}\text { Selective reporting (re- } \\
\text { porting bias) }\end{array}$ & High risk & $\begin{array}{l}\text { Did not report the frequency of diarrhea, the degree of dehydration and the } \\
\text { laboratory test results based on the methods described in the clinical trial reg- } \\
\text { istry (Registry number: ChiCTR-IPR-15007369) }\end{array}$ \\
\hline Other bias & Unclear risk & $\begin{array}{l}\text { The baseline is balanced between the treatment and control groups. However, } \\
\text { the source of funding is not mentioned }\end{array}$ \\
\hline
\end{tabular}

\section{Zakordonets 2016}

A prospective, randomized, controlled, open-label study
Withdrawal/Loss to follow-up: 41 eligible, 40 were randomized into 2 groups, 40 completed the study
ITT: N/A
Period of follow-up: During the course of antibiotic (7-14 days)

Participants $\quad \mathrm{N}=40$


Zakordonets 2016 (Continued)

Diagnosis: Meningococcal disease $(n=2)$; acute bacterial tonsillitis $(n=33)$; pseudotuberculosis $(n=2)$;

Lyme disease $(n=3)$

Country: Ukraine

Setting: Inpatient

Age: $3-17$ years (3-14 years in methods section)

Interventions

Probiotic: Symbiter acidophilus concentrated (multiprobiotic), 1 sachet/dose once a day. One sachet of

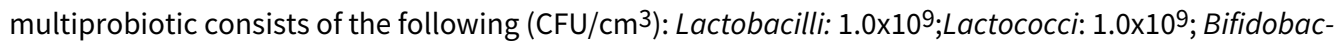
terium: $1.0 \times 10^{8}$; propionate-oxidising bacteria: $3.0 \times 10^{7}$; acetic acid bacteria: $1.0 \times 10^{5}$.The total dose is 2 trillion CFUs per day confirmed by email

Antibiotics: Ceftriaxone

Outcomes ID: 0 in treatment group (0/20), 6 in control group (6/20,30\%)

Definition of diarrhea: Daily production of at least 3 soft or liquid stools for at least 2 consecutive days

Notes

Funding: "The study was supported by the Research and Production Company "OD Prolisok" Grant 2013-20/03/2014 to Bogomolets National Medical University"

\section{Risk of bias}

\begin{tabular}{lll}
\hline Bias & Authors' judgement & Support for judgement \\
\hline $\begin{array}{l}\text { Random sequence genera- } \\
\text { tion (selection bias) }\end{array}$ & Low risk & $\begin{array}{l}\text { "Children were randomly assigned to two groups by using a computer-gener- } \\
\text { ated randomization list" }\end{array}$ \\
\hline $\begin{array}{l}\text { Allocation concealment } \\
\text { (selection bias) }\end{array}$ & Unclear risk & $\begin{array}{l}\text { "The allocation schedule was list fully concealed from doctors working in the } \\
\text { Clinical Department of Children's Infectious Diseases who recruited patients to } \\
\text { the study." However, there could be other parties, like nurses and residents, in- } \\
\text { volved in recruitment }\end{array}$ \\
\hline $\begin{array}{l}\text { Blinding (performance } \\
\text { bias and detection bias) }\end{array}$ & High risk & $\begin{array}{l}\text { Given this was an "open-label study design", participants and researchers } \\
\text { were not blinded }\end{array}$ \\
\hline $\begin{array}{l}\text { Incomplete outcome data } \\
\text { (attrition bias) }\end{array}$ & Low risk & $\begin{array}{l}\text { 40 patients were randomized into 2 groups. "All 40 patients completed the an- } \\
\text { tibiotic treatment period and intervention period" }\end{array}$ \\
\hline $\begin{array}{l}\text { Selective reporting (re- } \\
\text { porting bias) }\end{array}$ & Unclear risk & $\begin{array}{l}\text { There is no published protocol; therefore, there is not enough information to } \\
\text { assess reporting bias }\end{array}$ \\
\hline $\begin{array}{l}\text { Other bias } \\
\text { Thes }\end{array}$ & High risk & $\begin{array}{l}\text { The study was supported by the Research and Production Company "OD Pro- } \\
\text { lisok" }\end{array}$ \\
\hline
\end{tabular}

\section{Zhang 2015}

Randomized, but method not specified
Withdrawal/Loss to follow-up: 11 in total $(11 / 205,5.4 \%), 3$ in treatment $(3 / 105,2.9 \%), 8$ in control
$(8 / 100,8.0 \%)$
ITT: N/A


Period of follow-up: Not reported

\begin{tabular}{|c|c|}
\hline \multirow[t]{5}{*}{ Participants } & $\mathrm{N}=205,194$ received the full course of treatment \\
\hline & Diagnosis: H. pylori infection \\
\hline & Country: China \\
\hline & Setting: Outpatient \\
\hline & Age: 22 months- 16 years (mean $8.51 \pm 3.60$ years) \\
\hline \multirow[t]{2}{*}{ Interventions } & Probiotic: S. boulardii (500 mg per day, 10 billion CFUs) \\
\hline & $\begin{array}{l}\text { Antibiotic: Triple eradication therapy (omeprazole+amoxicillin+clarithromycin, or omeprazole+metron- } \\
\text { idazole+clarithromycin if penicillin allergy) }\end{array}$ \\
\hline \multirow[t]{2}{*}{ Outcomes } & $\begin{array}{l}\text { ID: } 12 \text { in treatment }(12 / 102,11.8 \%) \text {, severe } 1(1 / 12,8 \%) ; 26 \text { in control }(26 / 92,28.3 \%) \text {, severe } 5(5 / 26 \text {, } \\
\text { 19\%) }\end{array}$ \\
\hline & $\begin{array}{l}\text { Definition of diarrhea: An increase in the frequency of bowel movements to }>3 / \text { day or a decrease in } \\
\text { stool consistency (Bristol stool scale } 5 \text { or } 6 \text { ) }\end{array}$ \\
\hline Notes & $\begin{array}{l}\text { Funding: Not reported. However, the corresponding author is a consultant for United pharmaceuticals } \\
\text { and Biocodex. }\end{array}$ \\
\hline
\end{tabular}

\section{Risk of bias}

\begin{tabular}{|c|c|c|}
\hline Bias & Authors' judgement & Support for judgement \\
\hline \multirow[t]{2}{*}{$\begin{array}{l}\text { Random sequence genera- } \\
\text { tion (selection bias) }\end{array}$} & Unclear risk & $\begin{array}{l}\text { Insufficient information about the sequence generation process to permit } \\
\text { judgement of "Low risk" or "High risk" }\end{array}$ \\
\hline & & $\begin{array}{l}\text { "194 H. pylori positive children were randomized in } 2 \text { groups" but no further } \\
\text { explanation provided }\end{array}$ \\
\hline $\begin{array}{l}\text { Allocation concealment } \\
\text { (selection bias) }\end{array}$ & Unclear risk & $\begin{array}{l}\text { Unclear. "Our study does have some limitation as it is an open study." No allo- } \\
\text { cation concealment procedure outlined }\end{array}$ \\
\hline $\begin{array}{l}\text { Blinding (performance } \\
\text { bias and detection bias) } \\
\text { All outcomes }\end{array}$ & High risk & $\begin{array}{l}\text { Blinding not done.. "The findings of this trial need to be confirmed with a } \\
\text { prospective double blind study in which diagnosis is based on histology and } \\
\text { culture" }\end{array}$ \\
\hline $\begin{array}{l}\text { Incomplete outcome data } \\
\text { (attrition bias) } \\
\text { All outcomes }\end{array}$ & Low risk & $\begin{array}{l}205 \text { patients randomized, } 11 \text { lost to follow-up ( } 3 \text { in treatment group, } 8 \text { in con- } \\
\text { trol group), } 194 \text { analyzed. Attrition numbers low }\end{array}$ \\
\hline $\begin{array}{l}\text { Selective reporting (re- } \\
\text { porting bias) }\end{array}$ & Unclear risk & $\begin{array}{l}\text { No protocol published. There is not enough information to assess reporting } \\
\text { bias }\end{array}$ \\
\hline Other bias & Unclear risk & $\begin{array}{l}\text { Source of funding not reported. Yvan Vandenplas, who is a consultant for Unit- } \\
\text { ed Pharmaceuticals and Biocodex, is the corresponding author of the study }\end{array}$ \\
\hline
\end{tabular}

Zhao 2014

$\begin{array}{ll}\text { Methods } & \text { Randomized controlled trial } \\ & \text { Withdrawal/Loss to follow-up: } 0\end{array}$


Zhao 2014 (Continued)

ITT: N/A

Period of follow-up: End of antibiotic therapy

\begin{tabular}{ll}
\hline Participants & $\mathrm{N}=240$ \\
& Diagnosis: patients with $\mathrm{H}$. pylori infection diagnosed by $13 \mathrm{C}$ breath test \\
& Country: China \\
& Setting: Outpatient and inpatient \\
& Age: $7 \pm 2$ years in treatment group; $9 \pm 2$ years in control group \\
\hline Interventions & Probiotics: Saccharomyces boulardii $250 \mathrm{mg}$ twice a day $(10$ billion CFUs per day) \\
& Antibiotics: Amoxicillin, clarithromycin, omeprazole \\
\hline Outcomes & ID: 27 in treatment (27/120, $22.5 \%), 47$ in control (47/120, 39.2\%) \\
& Definition of diarrhea: Not reported. \\
\hline Notes & Funding source not reported.
\end{tabular}

\section{Risk of bias}

\begin{tabular}{|c|c|c|}
\hline Bias & Authors' judgement & Support for judgement \\
\hline $\begin{array}{l}\text { Random sequence genera- } \\
\text { tion (selection bias) }\end{array}$ & Low risk & Random number table method \\
\hline $\begin{array}{l}\text { Allocation concealment } \\
\text { (selection bias) }\end{array}$ & High risk & $\begin{array}{l}\text { Allocation concealment not reported. However, we assumed that risk of bias } \\
\text { was high for allocation concealment because probiotic group received } 4 \text { med- } \\
\text { ications while the control group received } 3 \text { medications }\end{array}$ \\
\hline $\begin{array}{l}\text { Blinding (performance } \\
\text { bias and detection bias) } \\
\text { All outcomes }\end{array}$ & High risk & $\begin{array}{l}\text { Not blinded. The control group is given triple therapy. The treatment group is } \\
\text { given triple therapy plus probiotics }\end{array}$ \\
\hline $\begin{array}{l}\text { Incomplete outcome data } \\
\text { (attrition bias) } \\
\text { All outcomes }\end{array}$ & Low risk & $\begin{array}{l}\text { All participants completed the trial. The total sample size is } 240 \text { ( } 120 \text { in each } \\
\text { group). All } 240 \text { were analysed }\end{array}$ \\
\hline $\begin{array}{l}\text { Selective reporting (re- } \\
\text { porting bias) }\end{array}$ & Unclear risk & The protocol was not published \\
\hline Other bias & Unclear risk & Funding source not mentioned \\
\hline
\end{tabular}

Zheng 2012

\begin{tabular}{ll}
\hline Methods & Randomized, open-label, no placebo-control \\
& Withdrawals/Loss to follow-up: 3 \\
& ITT: No \\
& Period of follow-up: 7 days \\
\hline Participants & $\mathrm{N}=372$ \\
\hline
\end{tabular}


Zheng 2012 (Continued)

Diagnosis: Pneumonia

Country: China

Setting: Hospital, in-patient, 7 sites

Age: average age in months: 13.99

\begin{tabular}{ll} 
Interventions & $\begin{array}{l}\text { Probiotics: Clostridium Butyricum (50 million CFUs), Bifidobacterium (500 million CFUs) } 4 \text { packets a day } \\
2.2 \text { billion CFUs/day } \\
\text { Antibiotics: mixed pencillin, cephalosporin, macrolides }\end{array}$ \\
\hline Outcomes & ID: Control $30(16.8 \%)$ versus Treatment 15 (7.8\%) \\
& $\begin{array}{l}\text { Definition of diarrhea: } 2 \text { or more BM over the pt amount (they has baseline BM \# for each pt. And an in- } \\
\text { crease of } 2 \text { or more over that baseline was considered diarrhea) }\end{array}$ \\
\hline Notes & Funding: NS
\end{tabular}

Risk of bias

\begin{tabular}{|c|c|c|}
\hline Bias & Authors' judgement & Support for judgement \\
\hline $\begin{array}{l}\text { Random sequence genera- } \\
\text { tion (selection bias) }\end{array}$ & Low risk & $\begin{array}{l}\text { Randomized block design. Use SAS software to generate } 504 \text { randomized } \\
\text { number for the } 7 \text { hospital ( } 72 \text { numbers for each center) }\end{array}$ \\
\hline $\begin{array}{l}\text { Allocation concealment } \\
\text { (selection bias) }\end{array}$ & High risk & $\begin{array}{l}\text { Investigator appears to know the randomization schedule when assigning par- } \\
\text { ticipants }\end{array}$ \\
\hline $\begin{array}{l}\text { Blinding (performance } \\
\text { bias and detection bias) } \\
\text { All outcomes }\end{array}$ & High risk & $\begin{array}{l}\text { No blinding procedure was described in the study. Seems to be an open label } \\
\text { trial. No mention of blinding. No treatment comparison }\end{array}$ \\
\hline $\begin{array}{l}\text { Incomplete outcome data } \\
\text { (attrition bias) } \\
\text { All outcomes }\end{array}$ & Low risk & $\begin{array}{l}3 \text { drop out of unknown reason \& } 5 \text { exclusion ( } 2 \text { due to incomplete report, } 3 \text { due } \\
\text { to rotavirus), from total of } 380 \text { (drop-out rate } 2.1 \% \text { ) }\end{array}$ \\
\hline $\begin{array}{l}\text { Selective reporting (re- } \\
\text { porting bias) }\end{array}$ & Low risk & $\begin{array}{l}\text { Their outcome report is consistent with the study protocol. Study is registered } \\
\text { at Chinese Ethics Committee of Registering Clinical Trials (http://www.chictrd- } \\
\text { b.org/)(ChiCTR-PRC-10001179) }\end{array}$ \\
\hline Other bias & Unclear risk & $\begin{array}{l}\text { The probiotic is provided by Shandong Kexing Bioproducts Co.,Ltd. (www.sd- } \\
\text { kexing.com) } \\
\text { No report for study funding }\end{array}$ \\
\hline
\end{tabular}

METHODS: Intention- to-treat (ITT), Not specified (NS)

PARTICIPANTS: respiratory tract infection (RTI), upper respiratory tract infection (URTI), lower respiratory tract infection (LRTI), Not specified (NS), Helicobacter Pylori (HP)

INTERVENTIONS: Bifidobacteria anamalis subsp. lactus (BA), Bifidobacterium breve (BB), Bacillus clausii (BC), Bifidobacterium infantis (BI), Bifidobacterium lactis (BL), Lactobacillus acidophilus (LA), Lactobacillus bularicus (LB), Lactococcus casei (LC), Lactobacillus delbrueckii subsp. bulgaris (LD), Lactobacillus GG (LGG), Lactococcus lactis (LL), Lactococcus plantarum (LP), Lactococcus rhamnosus (LR), Lactobacillus sporogens (LS), Fructo-Oligosaccaride (FOS), Saccharomyces boulardii (SB), Saccharomyces florentinus (SF), Streptococcus thermophilus (ST), Not available (NA)

OUTCOMES: Incidence of diarrhea (ID), Mean duration of diarhea (MDD)

\section{Characteristics of excluded studies [ordered by study ID]}




\begin{tabular}{|c|c|}
\hline Study & Reason for exclusion \\
\hline Adam 1977 & Pediatric level data could not be ascertained \\
\hline Beausoleil 2007 & Did not include children \\
\hline Brunser 2006 & Did not include probiotics as intervention \\
\hline Can 2006 & Did not include children \\
\hline Chapoy 1985 & Not randomized \\
\hline Contreras 1983 & Not randomized \\
\hline Czerwionka 2006 & Not randomized \\
\hline Dajani 2013 & Pediatric level data could not be ascertained \\
\hline Daschner 1979 & Not randomized \\
\hline Duman 2005 & Not a pediatric population \\
\hline Erdeve 2005 & Letter to the editor regarding pediatric $A A D$ \\
\hline Guandalini 1988 & Article could not be found \\
\hline Honeycutt 2007 & Did not administer probiotics concurrently with antibiotics \\
\hline Hosjak 2010 & AAD patient population excluded (studying nosocomial infections only) \\
\hline Hurduc 2009 & AAD outcome could not be obtained \\
\hline Imase 2008 & Not a pediatric population \\
\hline Islek 2015 & The intervention is synbiotic, not probiotic \\
\hline Kim 2008 & Did not include children \\
\hline Kleinkauf 1959 & Not randomized \\
\hline Koning 2008 & Did not include children \\
\hline Lei 2006 & Not associated with antibiotic use \\
\hline Lin 2009 & $\begin{array}{l}\text { Participants were not taking antibiotics concurrently with probiotics, or this data could not be as- } \\
\text { certained }\end{array}$ \\
\hline Lionetti 2006 & $\begin{array}{l}\text { Used a gastro-intestinal symptoms rating scale that, while inclusive of stool frequency and consis- } \\
\text { tency, did not report data specific to those outcomes }\end{array}$ \\
\hline McFarland 2005 & Letter to the editor regarding pediatric $A A D$ \\
\hline Michail 2011 & $\begin{array}{l}\text { Participants were not taking antibiotics concurrently with probiotics, or this data could not be as- } \\
\text { certained }\end{array}$ \\
\hline Michielutti 1996 & A study of acute diarrhea not associated with antibiotic use \\
\hline
\end{tabular}




\begin{tabular}{|c|c|}
\hline Study & Reason for exclusion \\
\hline Morrow 2010 & Not a pediatric population \\
\hline Nista 2004 & Not a pediatric population \\
\hline Pancheva 2009 & Incidence of vomiting and diarrhea were reported together \\
\hline Parfenov 2005 & $\begin{array}{l}\text { Participants were not taking antibiotics concurrently with probiotics, or this data could not be as- } \\
\text { certained }\end{array}$ \\
\hline Park 2007 & Not a pediatric population \\
\hline Penna 2009 & $\begin{array}{l}\text { Participants were not taking antibiotics concurrently with probiotics, or this data could not be as- } \\
\text { certained }\end{array}$ \\
\hline Plewinska 2006 & Not randomized \\
\hline Saavedra 1994 & $\begin{array}{l}\text { Participants were not taking antibiotics concurrently with probiotics, or this data could not be as- } \\
\text { certained }\end{array}$ \\
\hline Savas-Erdeve 2009 & $\begin{array}{l}\text { Involved Sacchromyces boulardii for pediatric infectious diarrhea (i.e., amebiasis-associated diar- } \\
\text { rhea) not antibiotic associated diarrhea }\end{array}$ \\
\hline Schrezenmeir 2004 & Did not report outcomes particular to AAD \\
\hline Seki 2003 & Not randomized \\
\hline Siitonen 1990 & Not a pediatric population \\
\hline Simakachorn 2011 & $\begin{array}{l}\text { Participants were not taking antibiotics concurrently with probiotics, or this data could not be as- } \\
\text { certained }\end{array}$ \\
\hline Srinivasan 2006 & Did not report outcomes particular to AAD \\
\hline Szajewka 2001 & Did not evaluate antibiotic use \\
\hline Thomas 2001 & Not a pediatric population \\
\hline Tolone 2012 & Had a high dose of prebiotics (> 5 grams) \\
\hline Valsecchi 2014 & No diarrhea outcome \\
\hline Wanke 2012 & Probiotics not administered concurrently with antibiotics \\
\hline Weizman 2005 & Not associated with antibiotic use \\
\hline Wenus 2008 & Did not include children \\
\hline Witsell 1995 & Not a pediatric population \\
\hline Zoppi 2001 & Primary outcome not diarrhea. A study of how antibiotics effect the gut flora \\
\hline
\end{tabular}

AAD: antibiotic-associated diarrhea

Characteristics of ongoing studies [ordered by study ID] 
NCT02722993

\begin{tabular}{|c|c|}
\hline Trial name or title & Efficacy of a Probiotic Product in Children With Antibiotic-associated Gastrointestinal Disorders \\
\hline Methods & Randomized \\
\hline Participants & Children at the age of $1-11$ years that have been prescribed antibiotic treatment \\
\hline Interventions & Probiotics vs placebo \\
\hline Outcomes & Number of loose/watery stools (Time frame: 19-26 days) \\
\hline Starting date & February 3, 2016 \\
\hline Contact information & $\begin{array}{l}\text { Piotr Socha, Prof. Children's Memorial Health Institute, Warzaw, Poland (No contact information } \\
\text { provided) }\end{array}$ \\
\hline Notes & Actual enrollment: 117 participants. Actual study completion Date :May 8, 2017 \\
\hline
\end{tabular}

\section{NCT02765217}

\begin{tabular}{ll}
\hline Trial name or title & $\begin{array}{l}\text { Effect of Lactobacillus Reuteri DSM 17938 to Prevent Antibiotic-associated Diarrhea in Children: } \\
\text { Prospective, Multi-center, Randomize, Parallel Group Placebo Controlled Clinical Trial }\end{array}$ \\
\hline Methods & Randomized \\
\hline Participants & $\begin{array}{l}\text { Children receiving amoxicilline-clavulanic acid (50-90 mg/kg/day, twice daily) due to acute otitis } \\
\text { media or acute sinusitis, with aged from 6 months to } 18 \text { years }\end{array}$ \\
\hline Interventions & $\begin{array}{l}\text { 3 study arms: group 1 (Lactobacillus reuteri DSM 17938 with 5 drops vs Amoxicillin-Clavulanic acid); } \\
\text { group 2 (placebo vs Amoxicillin-Clavulanic acid); group 3 (Lactobacillus reuteri DSM 17938 with 2*5 } \\
\text { drops vs Amoxicillin-Clavulanic acid) }\end{array}$ \\
\hline Outcomes & $\begin{array}{l}\text { Incidence of antibiotic associated diarrhea (Time Frame: } 8 \text { weeks time period after 1st day of an- } \\
\text { tibiotic use) }\end{array}$ \\
\hline Starting date & June 1, 2017 \\
\hline Contact information & Ener C Dinleyici, MD; enercagri@gmail.com \\
\hline Notes & Estimated enrollment: 1440 \\
\hline
\end{tabular}

\section{NCT02993419}

\section{Trial name or title}

Methods

Participants

Interventions

Bacillus Particles Prevent More Children's Antibiotic-associated Diarrhea (AAD), Randomized, Double-blind, Controlled Clinical Trial

$$
\text { A prospective, multicenter, randomized, double-blind, placebo-controlled clinical study }
$$

Participants aged from 1 month to 3 years old, with diagnosed lower respiratory tract infection

Treatment group with Bacillus licheniformis Intervention; Control group with placebo Intervention

Record daily stool frequency, shape observation excrement 
NCT02993419 (Continued)

Starting date December 2016

\begin{tabular}{ll}
\hline Contact information & No contacts provided \\
\hline Notes & Estimated enrollment: 480
\end{tabular}

NCT03181516

\begin{tabular}{ll}
\hline Trial name or title & Efficacy and Safety of BB-12 Supplemented Strawberry Yogurt For Healthy Children on Antibiotics \\
\hline Methods & Randomized \\
\hline Participants & $\begin{array}{l}\text { Child aged from } 3 \text { to } 12 \text { years, with taking a penicillin or cephalosporin class antibiotic regimen for } \\
10 \text { days for a respiratory infection }\end{array}$ \\
\hline Interventions & $\begin{array}{l}\text { Bifidobacterium animalis subsp. lactis BB-12-supplemented yogurt vs yogurt without Bifidobac- } \\
\text { terium animalis subsp. lactis BB-12 }\end{array}$ \\
\hline Outcomes & Diarrhea (Time Frame: 14 days) \\
\hline Starting date & September 30, 2017 \\
\hline Contact information & Dan Merenstein, MD; djm23@georgetown.edu \\
\hline Notes & Estimated enrollment: 300 \\
\hline
\end{tabular}

\section{NCT03334604}

Trial name or title

The Effect of a Multispecies Probiotic on Reducing the Incidence of Antibiotic-associated Diarrhoea in Children

\begin{tabular}{ll}
\hline Methods & Randomized \\
\hline Participants & Children aged 6 months to 18 years, undergoing antibiotic treatment \\
\hline Interventions & $\begin{array}{l}\text { Multispecies probiotic (consisting of Bifidobacterium bifidum W23, Bifidobacterium lactis W51, } \\
\text { Lactobacillus acidophilus W37, Lactobacillus acidophilus W55, Lactobacillus paracasei W20, Lacto- } \\
\text { bacillus plantarum W62, Lactobacillus rhamnosus W71 and Lactobacillus salivarius W24 at a dose } \\
\text { of } 5 \times 10^{\wedge} 9 \text { Colony Forming Units (CFU), twice daily, orally) vs placebo }\end{array}$ \\
\hline
\end{tabular}

Outcomes Incidence of antibiotic-associated diarrhea (Time Frame: Up to 7th day after antibiotic cessation

\begin{tabular}{ll}
\hline Starting date & February 16, 2018 \\
\hline Contact information & Hanna Szajewska, MD, PhD; hania@ipgate.com \\
\hline Notes & Estimated enrollment: 350 \\
\hline
\end{tabular}




\section{DATA AND ANALYSES}

\section{Comparison 1. Probiotics versus control}

\begin{tabular}{|c|c|c|c|c|}
\hline Outcome or subgroup title & No. of studies & $\begin{array}{l}\text { No. of partici- } \\
\text { pants }\end{array}$ & Statistical method & Effect size \\
\hline 1 Incidence of diarrhea: Complete case & 33 & 6352 & $\begin{array}{l}\text { Risk Ratio (M-H, Random, } \\
95 \% \mathrm{Cl})\end{array}$ & $0.45[0.36,0.56]$ \\
\hline $\begin{array}{l}1.1 \text { Incidence of Diarrhea: Active con- } \\
\text { trolled trials }\end{array}$ & 2 & 773 & $\begin{array}{l}\text { Risk Ratio (M-H, Random, } \\
95 \% \mathrm{Cl})\end{array}$ & $0.85[0.33,2.21]$ \\
\hline $\begin{array}{l}1.2 \text { Incidence of Diarrhea: Placebo con- } \\
\text { trolled trials }\end{array}$ & 19 & 2335 & $\begin{array}{l}\text { Risk Ratio (M-H, Random, } \\
95 \% \mathrm{Cl})\end{array}$ & $0.50[0.37,0.67]$ \\
\hline $\begin{array}{l}1.3 \text { Incidence of Diarrhea: No treat- } \\
\text { ment control }\end{array}$ & 12 & 3244 & $\begin{array}{l}\text { Risk Ratio (M-H, Random, } \\
95 \% \mathrm{Cl})\end{array}$ & $0.35[0.26,0.47]$ \\
\hline $\begin{array}{l}2 \text { Incidence of diarrhea: Inpatient ver- } \\
\text { sus outpatient }\end{array}$ & 21 & 3949 & $\begin{array}{l}\text { Risk Ratio (M-H, Random, } \\
95 \% \mathrm{Cl})\end{array}$ & $0.44[0.31,0.61]$ \\
\hline 2.1 Inpatient & 10 & 1469 & $\begin{array}{l}\text { Risk Ratio (M-H, Random, } \\
95 \% \mathrm{Cl})\end{array}$ & $0.34[0.26,0.45]$ \\
\hline 2.2 Outpatient & 11 & 2480 & $\begin{array}{l}\text { Risk Ratio (M-H, Random, } \\
95 \% \mathrm{Cl})\end{array}$ & $0.54[0.33,0.88]$ \\
\hline 3 Incidence of diarrhea: Diagnosis & 27 & 4847 & $\begin{array}{l}\text { Risk Ratio (M-H, Random, } \\
95 \% \mathrm{Cl})\end{array}$ & $0.43[0.34,0.55]$ \\
\hline $3.1 \mathrm{H}$. pylori & 6 & 700 & $\begin{array}{l}\text { Risk Ratio (M-H, Random, } \\
95 \% \mathrm{Cl})\end{array}$ & $0.48[0.35,0.64]$ \\
\hline 3.2 Respiratory Infections & 6 & 1064 & $\begin{array}{l}\text { Risk Ratio (M-H, Random, } \\
95 \% \mathrm{Cl})\end{array}$ & $0.44[0.33,0.61]$ \\
\hline 3.3 Mixed & 15 & 3083 & $\begin{array}{l}\text { Risk Ratio (M-H, Random, } \\
95 \% \mathrm{Cl})\end{array}$ & $0.43[0.27,0.67]$ \\
\hline $\begin{array}{l}4 \text { Incidence of diarrhea: Probiotic } \\
\text { species }\end{array}$ & 33 & 6352 & $\begin{array}{l}\text { Risk Ratio (M-H, Random, } \\
95 \% \mathrm{Cl})\end{array}$ & $0.45[0.36,0.56]$ \\
\hline $\begin{array}{l}\text { 4.1 Lactobacillus rhamnosus (strains: } \\
\text { GG, ATCC53103 and E/N, Oxy, Pen) }\end{array}$ & 6 & 686 & $\begin{array}{l}\text { Risk Ratio (M-H, Random, } \\
95 \% \mathrm{Cl})\end{array}$ & $0.37[0.24,0.55]$ \\
\hline 4.2 L. acidophilus \& L. bulgaricus & 1 & 38 & $\begin{array}{l}\text { Risk Ratio (M-H, Random, } \\
95 \% \mathrm{Cl})\end{array}$ & $0.96[0.61,1.50]$ \\
\hline $\begin{array}{l}4.3 \text { L. acidophilus and Bifidobacterium } \\
\text { infantis }\end{array}$ & 1 & 18 & $\begin{array}{l}\text { Risk Ratio (M-H, Random, } \\
95 \% \mathrm{Cl})\end{array}$ & $0.47[0.18,1.21]$ \\
\hline 4.4 L. sporogenes & 1 & 98 & $\begin{array}{l}\text { Risk Ratio (M-H, Random, } \\
95 \% \mathrm{Cl})\end{array}$ & $0.47[0.29,0.77]$ \\
\hline 4.5 Saccharomyces boulardii & 9 & 3165 & $\begin{array}{l}\text { Risk Ratio (M-H, Random, } \\
95 \% \mathrm{Cl})\end{array}$ & $0.36[0.24,0.54]$ \\
\hline
\end{tabular}




\begin{tabular}{|c|c|c|c|c|}
\hline Outcome or subgroup title & No. of studies & $\begin{array}{l}\text { No. of partici- } \\
\text { pants }\end{array}$ & Statistical method & Effect size \\
\hline $\begin{array}{l}\text { 4.6 Bifidobacterium. lactis \& Strepto- } \\
\text { coccus. thermophilus }\end{array}$ & 1 & 157 & $\begin{array}{l}\text { Risk Ratio (M-H, Random, } \\
95 \% \mathrm{Cl} \text { ) }\end{array}$ & $0.52[0.29,0.95]$ \\
\hline 4.7 Bacillus clausii & 1 & 323 & $\begin{array}{l}\text { Risk Ratio (M-H, Random, } \\
95 \% \mathrm{Cl})\end{array}$ & $0.43[0.11,1.62]$ \\
\hline $\begin{array}{l}\text { 4.8 Lactococcus lactis, L. plantarum, L. } \\
\text { rhamnosus, L. casei, L. lactis subspecies } \\
\text { diacetylactis, Leuconostoc cremoris, Bi- } \\
\text { fidobacterium longum, B. breve, Lac- } \\
\text { tobacillus acidophilus, and Saccha- } \\
\text { romyces florentinus }\end{array}$ & 1 & 117 & $\begin{array}{l}\text { Risk Ratio (M-H, Random, } \\
95 \% \mathrm{Cl})\end{array}$ & $0.83[0.41,1.67]$ \\
\hline $\begin{array}{l}4.9 \text { Bifidobacterium longum PL03, Lac- } \\
\text { tobacillus rhamnosus KL53A, and Lac- } \\
\text { tobacillus plantarum PL02 }\end{array}$ & 1 & 78 & $\begin{array}{l}\text { Risk Ratio (M-H, Random, } \\
95 \% \mathrm{Cl})\end{array}$ & $0.48[0.04,5.03]$ \\
\hline $\begin{array}{l}\text { 4.10 Streptococcus thermophillus, L. } \\
\text { acidophilus, B. anamalis subsp. lactus, } \\
\text { L. delbrueckii subsp. bulgaris }\end{array}$ & 1 & 106 & $\begin{array}{l}\text { Risk Ratio (M-H, Random, } \\
95 \% \mathrm{Cl})\end{array}$ & $1.73[0.39,7.70]$ \\
\hline $\begin{array}{l}\text { 4.11 Lactobacillus rhamnosus GG, Bi- } \\
\text { fidobacterium animalis subsp. Lactis } \\
\text { Bv-12, L. acidophilus LA-5 }\end{array}$ & 1 & 70 & $\begin{array}{l}\text { Risk Ratio (M-H, Random, } \\
95 \% \mathrm{Cl})\end{array}$ & $0.08[0.00,1.39]$ \\
\hline $\begin{array}{l}\text { 4.12 Lactobasillus casei, Lactobacillus } \\
\text { acidophilus, Lactobasillus reuteri, Lac- } \\
\text { tobasillus bulgaricus, Streptococcus, Bi- } \\
\text { fidobacterium bifidum, Bifidobacterium } \\
\text { infantis }\end{array}$ & 1 & 50 & $\begin{array}{l}\text { Risk Ratio (M-H, Random, } \\
95 \% \mathrm{Cl})\end{array}$ & $0.23[0.07,0.71]$ \\
\hline 4.13 Lactobacillus reuteri DSM 17938 & 2 & 344 & $\begin{array}{l}\text { Risk Ratio (M-H, Random, } \\
95 \% \mathrm{Cl})\end{array}$ & $1.68[0.76,3.72]$ \\
\hline $\begin{array}{l}\text { 4.14 Lactobacillus acidophilus, Lacto- } \\
\text { bacillus rhamnosus, Lactobacillus bul- } \\
\text { garicus, Lactobacillus casei, Strepto- } \\
\text { coccus thermophilus, Bifidobacterium } \\
\text { infantis and Bifidobacterium breve }\end{array}$ & 1 & 66 & $\begin{array}{l}\text { Risk Ratio (M-H, Random, } \\
95 \% \mathrm{Cl})\end{array}$ & $0.25[0.06,1.09]$ \\
\hline 4.15 L. casei DN-114 001 & 1 & 86 & $\begin{array}{l}\text { Risk Ratio (M-H, Random, } \\
95 \% \mathrm{Cl})\end{array}$ & $0.72[0.18,2.84]$ \\
\hline $\begin{array}{l}\text { 4.16 Clostridium Butyricum and Bifi- } \\
\text { dobacterium }\end{array}$ & 1 & 372 & $\begin{array}{l}\text { Risk Ratio (M-H, Random, } \\
95 \% \mathrm{Cl})\end{array}$ & $0.46[0.26,0.83]$ \\
\hline 4.17 Lactobacillus plantarum DSM 9843 & 1 & 438 & $\begin{array}{l}\text { Risk Ratio (M-H, Random, } \\
95 \% \mathrm{Cl})\end{array}$ & $0.67[0.24,1.86]$ \\
\hline $\begin{array}{l}\text { 4.18 Lactobacilli and Lactococci, Bifi- } \\
\text { dobacterium, propionate-oxidising bac- } \\
\text { teria and acetic acid bacteria }\end{array}$ & 1 & 40 & $\begin{array}{l}\text { Risk Ratio (M-H, Random, } \\
95 \% \mathrm{Cl})\end{array}$ & $0.08[0.00,1.28]$ \\
\hline $\begin{array}{l}\text { 4.19 Lactobacillus sporegens, Strepto- } \\
\text { coccus faecalis, clostridium butyricum } \\
\text { and Bacillus mesentericus }\end{array}$ & 1 & 100 & $\begin{array}{l}\text { Risk Ratio (M-H, Random, } \\
95 \% \mathrm{Cl})\end{array}$ & $0.14[0.01,2.70]$ \\
\hline
\end{tabular}




\begin{tabular}{|c|c|c|c|c|}
\hline Outcome or subgroup title & No. of studies & $\begin{array}{l}\text { No. of partici- } \\
\text { pants }\end{array}$ & Statistical method & Effect size \\
\hline $\begin{array}{l}5 \text { Incidence of diarrhea: Single strain } \\
\text { versus multi strain }\end{array}$ & 33 & 6352 & $\begin{array}{l}\text { Risk Ratio (M-H, Random, } \\
95 \% \mathrm{Cl} \text { ) }\end{array}$ & $0.45[0.36,0.56]$ \\
\hline 5.1 Single Strain & 20 & 4900 & $\begin{array}{l}\text { Risk Ratio (M-H, Random, } \\
95 \% \mathrm{Cl} \text { ) }\end{array}$ & $0.42[0.32,0.56]$ \\
\hline 5.2 Multi Strain & 13 & 1452 & $\begin{array}{l}\text { Risk Ratio (M-H, Random, } \\
95 \% \mathrm{Cl} \text { ) }\end{array}$ & $0.53[0.37,0.75]$ \\
\hline 6 Incidence of diarrhea: Probiotic dose & 32 & 6252 & $\begin{array}{l}\text { Risk Ratio (M-H, Random, } \\
95 \% \mathrm{Cl} \text { ) }\end{array}$ & $0.45[0.36,0.57]$ \\
\hline $6.1 \geq 5$ billion CFUs of probiotic/day & 20 & 4038 & $\begin{array}{l}\text { Risk Ratio (M-H, Random, } \\
95 \% \mathrm{Cl} \text { ) }\end{array}$ & $0.37[0.30,0.46]$ \\
\hline $6.2<5$ billion CFUs of probiotic/day & 12 & 2214 & $\begin{array}{l}\text { Risk Ratio (M-H, Random, } \\
95 \% \mathrm{Cl} \text { ) }\end{array}$ & $0.68[0.46,1.01]$ \\
\hline $\begin{array}{l}7 \text { Incidence of diarrhea: Definition of } \\
\text { diarrhea }\end{array}$ & 27 & 6499 & $\begin{array}{l}\text { Risk Ratio (M-H, Random, } \\
95 \% \mathrm{Cl} \text { ) }\end{array}$ & $0.41[0.31,0.54]$ \\
\hline $\begin{array}{l}7.13 \text { or more watery/liquid stools for } \\
\text { more than } 2 \text { days }\end{array}$ & 2 & 317 & $\begin{array}{l}\text { Risk Ratio (M-H, Random, } \\
95 \% \mathrm{Cl} \text { ) }\end{array}$ & $0.50[0.02,11.75]$ \\
\hline $\begin{array}{l}7.23 \text { or more loose/watery/liquid } \\
\text { stools per day for at least } 2 \text { consecutive } \\
\text { days }\end{array}$ & 13 & 1873 & $\begin{array}{l}\text { Risk Ratio (M-H, Random, } \\
95 \% \mathrm{Cl})\end{array}$ & $0.36[0.25,0.50]$ \\
\hline $\begin{array}{l}7.3 \geq 3 \text { watery/liquid stools per } 24 \\
\text { hours }\end{array}$ & 9 & 2748 & $\begin{array}{l}\text { Risk Ratio (M-H, Random, } \\
95 \% \mathrm{Cl} \text { ) }\end{array}$ & $0.48[0.31,0.76]$ \\
\hline $\begin{array}{l}7.4 \geq 2 \text { liquid stools per day on at least } 2 \\
\text { occasions during study }\end{array}$ & 2 & 258 & $\begin{array}{l}\text { Risk Ratio (M-H, Random, } \\
95 \% \mathrm{Cl} \text { ) }\end{array}$ & $0.24[0.09,0.65]$ \\
\hline $\begin{array}{l}7.5 \geq 2 \text { loose/watery/liquid stools for } \\
\text { more than } 2 \text { days }\end{array}$ & 2 & 478 & $\begin{array}{l}\text { Risk Ratio (M-H, Random, } \\
95 \% \mathrm{Cl} \text { ) }\end{array}$ & $0.12[0.05,0.27]$ \\
\hline $7.6 \geq 2$ liquid stools per $24 \mathrm{hr}$ & 2 & 345 & $\begin{array}{l}\text { Risk Ratio (M-H, Random, } \\
95 \% \mathrm{Cl} \text { ) }\end{array}$ & $0.65[0.32,1.30]$ \\
\hline $\begin{array}{l}7.7 \geq 1 \text { abnormally loose bowel move- } \\
\text { ment per } 24 \text { hrs }\end{array}$ & 1 & 38 & $\begin{array}{l}\text { Risk Ratio (M-H, Random, } \\
95 \% \mathrm{Cl} \text { ) }\end{array}$ & $0.96[0.61,1.50]$ \\
\hline $\begin{array}{l}7.82 \text { or more BM over the patient's } \\
\text { normal }\end{array}$ & 1 & 372 & $\begin{array}{l}\text { Risk Ratio (M-H, Random, } \\
95 \% \mathrm{Cl})\end{array}$ & $0.46[0.26,0.83]$ \\
\hline 7.9 "Any of Above (Fox)" & 1 & 70 & $\begin{array}{l}\text { Risk Ratio (M-H, Random, } \\
95 \% \mathrm{Cl} \text { ) }\end{array}$ & $0.04[0.01,0.27]$ \\
\hline $\begin{array}{l}8 \text { Incidence of diarrhea: Strictness of } \\
\text { definition (mild vs moderate) }\end{array}$ & 25 & 5408 & $\begin{array}{l}\text { Risk Ratio (M-H, Random, } \\
95 \% \mathrm{Cl} \text { ) }\end{array}$ & $0.41[0.32,0.53]$ \\
\hline 8.1 Moderate diarrhea & 20 & 4304 & $\begin{array}{l}\text { Risk Ratio (M-H, Random, } \\
95 \% \mathrm{Cl})\end{array}$ & $0.40[0.31,0.53]$ \\
\hline
\end{tabular}




\begin{tabular}{|c|c|c|c|c|}
\hline Outcome or subgroup title & No. of studies & $\begin{array}{l}\text { No. of partici- } \\
\text { pants }\end{array}$ & Statistical method & Effect size \\
\hline 8.2 Mild diarrhea & 5 & 1104 & $\begin{array}{l}\text { Risk Ratio (M-H, Random, } \\
95 \% \mathrm{Cl})\end{array}$ & $0.41[0.22,0.77]$ \\
\hline $\begin{array}{l}9 \text { Incidence of diarrhea: Industry spon- } \\
\text { sorship }\end{array}$ & 17 & 2942 & $\begin{array}{l}\text { Risk Ratio (M-H, Random, } \\
95 \% \mathrm{Cl})\end{array}$ & $0.51[0.34,0.75]$ \\
\hline 9.1 Industry Sponsored & 9 & 1627 & $\begin{array}{l}\text { Risk Ratio (M-H, Random, } \\
95 \% \mathrm{Cl})\end{array}$ & $0.58[0.40,0.82]$ \\
\hline 9.2 Non-Industry & 8 & 1315 & $\begin{array}{l}\text { Risk Ratio (M-H, Random, } \\
95 \% \mathrm{Cl} \text { ) }\end{array}$ & $0.43[0.18,1.00]$ \\
\hline 10 Incidence of diarrhea: Risk of bias & 33 & 6352 & $\begin{array}{l}\text { Risk Ratio (M-H, Random, } \\
95 \% \mathrm{Cl} \text { ) }\end{array}$ & $0.45[0.36,0.56]$ \\
\hline 10.1 Low Risk & 13 & 2170 & $\begin{array}{l}\text { Risk Ratio (M-H, Random, } \\
95 \% \mathrm{Cl})\end{array}$ & $0.53[0.37,0.77]$ \\
\hline 10.2 High Risk & 20 & 4182 & $\begin{array}{l}\text { Risk Ratio (M-H, Random, } \\
95 \% \mathrm{Cl})\end{array}$ & $0.42[0.31,0.56]$ \\
\hline 11 Incidence of diarrhea: age & 32 & 5752 & $\begin{array}{l}\text { Risk Ratio (M-H, Random, } \\
95 \% \mathrm{Cl} \text { ) }\end{array}$ & $0.47[0.37,0.58]$ \\
\hline $11.10-2$ years ( $\leq 24$ months) & 6 & 1127 & $\begin{array}{l}\text { Risk Ratio (M-H, Random, } \\
95 \% \mathrm{Cl} \text { ) }\end{array}$ & $0.37[0.26,0.53]$ \\
\hline $11.2>2$ years (>24 months) & 26 & 4625 & $\begin{array}{l}\text { Risk Ratio (M-H, Random, } \\
95 \% \mathrm{Cl} \text { ) }\end{array}$ & $0.50[0.39,0.66]$ \\
\hline $\begin{array}{l}12 \text { Incidence of diarrhea: Sensitivity } \\
\text { analysis (complete case - fixed effects) }\end{array}$ & 33 & 6352 & $\begin{array}{l}\text { Risk Ratio (M-H, Fixed, 95\% } \\
\mathrm{Cl} \text { ) }\end{array}$ & $0.43[0.37,0.49]$ \\
\hline 12.1 Active controlled & 2 & 773 & $\begin{array}{l}\text { Risk Ratio (M-H, Fixed, 95\% } \\
\mathrm{Cl})\end{array}$ & $0.87[0.58,1.32]$ \\
\hline 12.2 Placebo controlled & 19 & 2335 & $\begin{array}{l}\text { Risk Ratio (M-H, Fixed, 95\% } \\
\mathrm{Cl})\end{array}$ & $0.48[0.39,0.59]$ \\
\hline 12.3 No treatment control & 12 & 3244 & $\begin{array}{l}\text { Risk Ratio (M-H, Fixed, 95\% } \\
\mathrm{Cl} \text { ) }\end{array}$ & $0.34[0.28,0.41]$ \\
\hline $\begin{array}{l}13 \text { Incidence of diarrhea: Probiotic } \\
\text { dose (extreme-plausible analysis) }\end{array}$ & 33 & 7019 & $\begin{array}{l}\text { Risk Ratio (M-H, Random, } \\
95 \% \mathrm{Cl})\end{array}$ & $0.61[0.49,0.77]$ \\
\hline $13.1 \geq 5$ billion CFUs of probiotic/day & 20 & 4425 & $\begin{array}{l}\text { Risk Ratio (M-H, Random, } \\
95 \% \mathrm{Cl})\end{array}$ & $0.54[0.42,0.70]$ \\
\hline $13.2<5$ billion CFUs of probiotic/day & 13 & 2594 & $\begin{array}{l}\text { Risk Ratio (M-H, Random, } \\
95 \% \mathrm{Cl} \text { ) }\end{array}$ & $0.80[0.54,1.20]$ \\
\hline $\begin{array}{l}14 \text { Incidence of diarrhea: Sensitivity } \\
\text { analysis (missing outcome data - ex- } \\
\text { treme plausible analysis) }\end{array}$ & 33 & 7019 & $\begin{array}{l}\text { Risk Ratio (M-H, Random, } \\
95 \% \mathrm{Cl})\end{array}$ & $0.61[0.49,0.77]$ \\
\hline
\end{tabular}




\begin{tabular}{|c|c|c|c|c|}
\hline Outcome or subgroup title & No. of studies & $\begin{array}{l}\text { No. of partici- } \\
\text { pants }\end{array}$ & Statistical method & Effect size \\
\hline 14.1 Active controlled & 2 & 948 & $\begin{array}{l}\text { Risk Ratio (M-H, Random, } \\
95 \% \mathrm{Cl})\end{array}$ & $1.07[0.40,2.86]$ \\
\hline 14.2 Placebo controlled & 19 & 2571 & $\begin{array}{l}\text { Risk Ratio (M-H, Random, } \\
95 \% \mathrm{Cl} \text { ) }\end{array}$ & $0.71[0.54,0.92]$ \\
\hline 14.3 No treatment control & 12 & 3500 & $\begin{array}{l}\text { Risk Ratio (M-H, Random, } \\
95 \% \mathrm{Cl} \text { ) }\end{array}$ & $0.46[0.31,0.66]$ \\
\hline 15 Adverse events: Complete case & 24 & 4415 & $\begin{array}{l}\text { Risk Difference (M-H, Ran- } \\
\text { dom, } 95 \% \mathrm{Cl} \text { ) }\end{array}$ & $-0.00[-0.01,0.01]$ \\
\hline $\begin{array}{l}16 \text { Adverse events: Same event rate as- } \\
\text { sumptions analysis }\end{array}$ & 24 & 4595 & $\begin{array}{l}\text { Risk Difference (M-H, Ran- } \\
\text { dom, } 95 \% \mathrm{Cl} \text { ) }\end{array}$ & $-0.00[-0.01,0.01]$ \\
\hline 17 Adverse events: Risk of bias & 24 & 4415 & $\begin{array}{l}\text { Risk Difference (M-H, Ran- } \\
\text { dom, } 95 \% \mathrm{Cl})\end{array}$ & $-0.00[-0.01,0.01]$ \\
\hline 17.1 Low RoB & 11 & 1978 & $\begin{array}{l}\text { Risk Difference (M-H, Ran- } \\
\text { dom, } 95 \% \mathrm{Cl})\end{array}$ & $-0.02[-0.05,0.01]$ \\
\hline 17.2 High/Unclear & 13 & 2437 & $\begin{array}{l}\text { Risk Difference (M-H, Ran- } \\
\text { dom, } 95 \% \mathrm{Cl})\end{array}$ & $0.00[-0.00,0.00]$ \\
\hline $\begin{array}{l}18 \text { Mean duration of diarrhea: Com- } \\
\text { plete case }\end{array}$ & 8 & 1263 & $\begin{array}{l}\text { Mean Difference (IV, Ran- } \\
\text { dom, } 95 \% \mathrm{CI} \text { ) }\end{array}$ & $-0.91[-1.38,-0.44]$ \\
\hline
\end{tabular}

Analysis 1.1. Comparison 1 Probiotics versus control, Outcome 1 Incidence of diarrhea: Complete case.

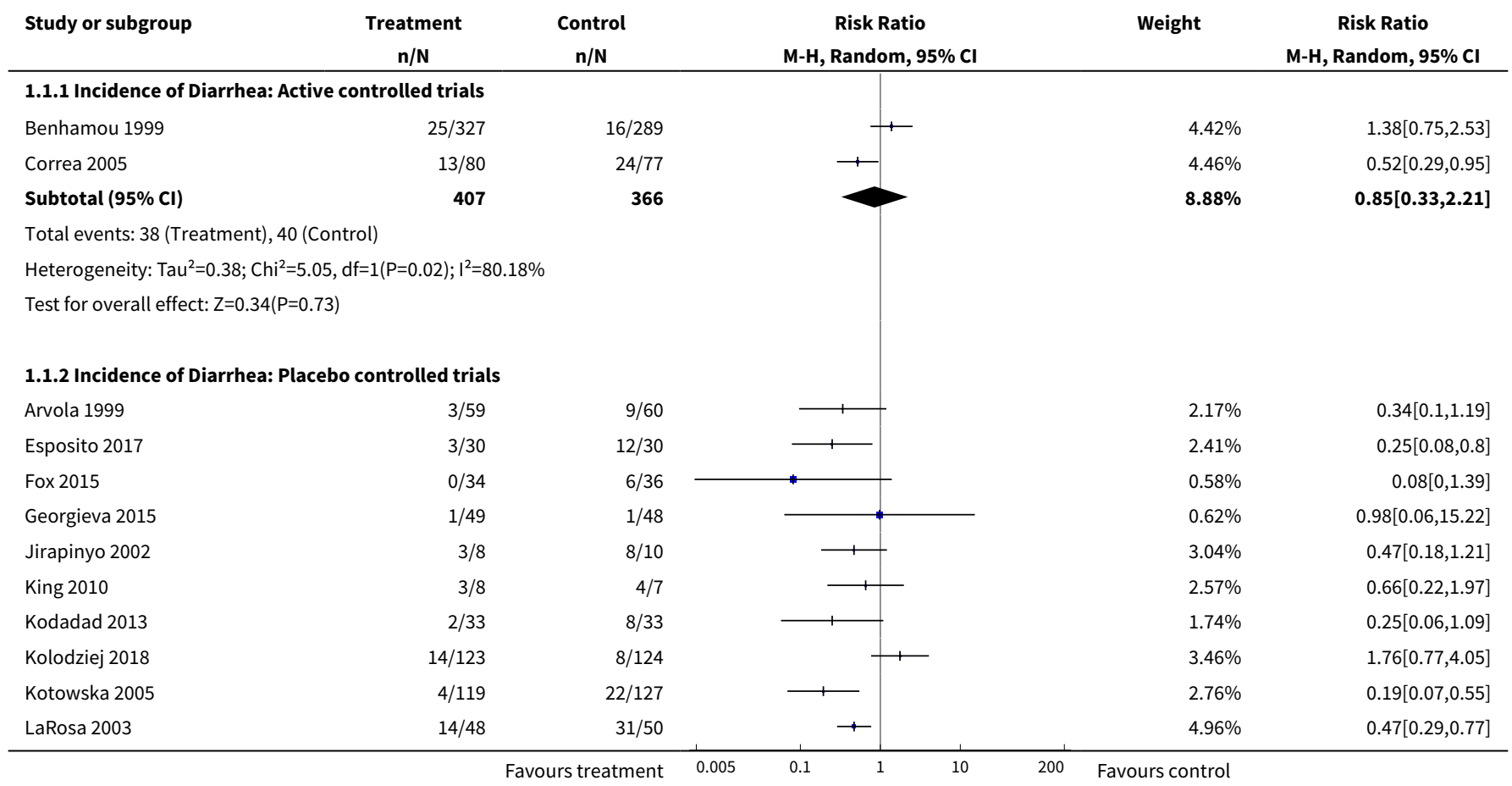




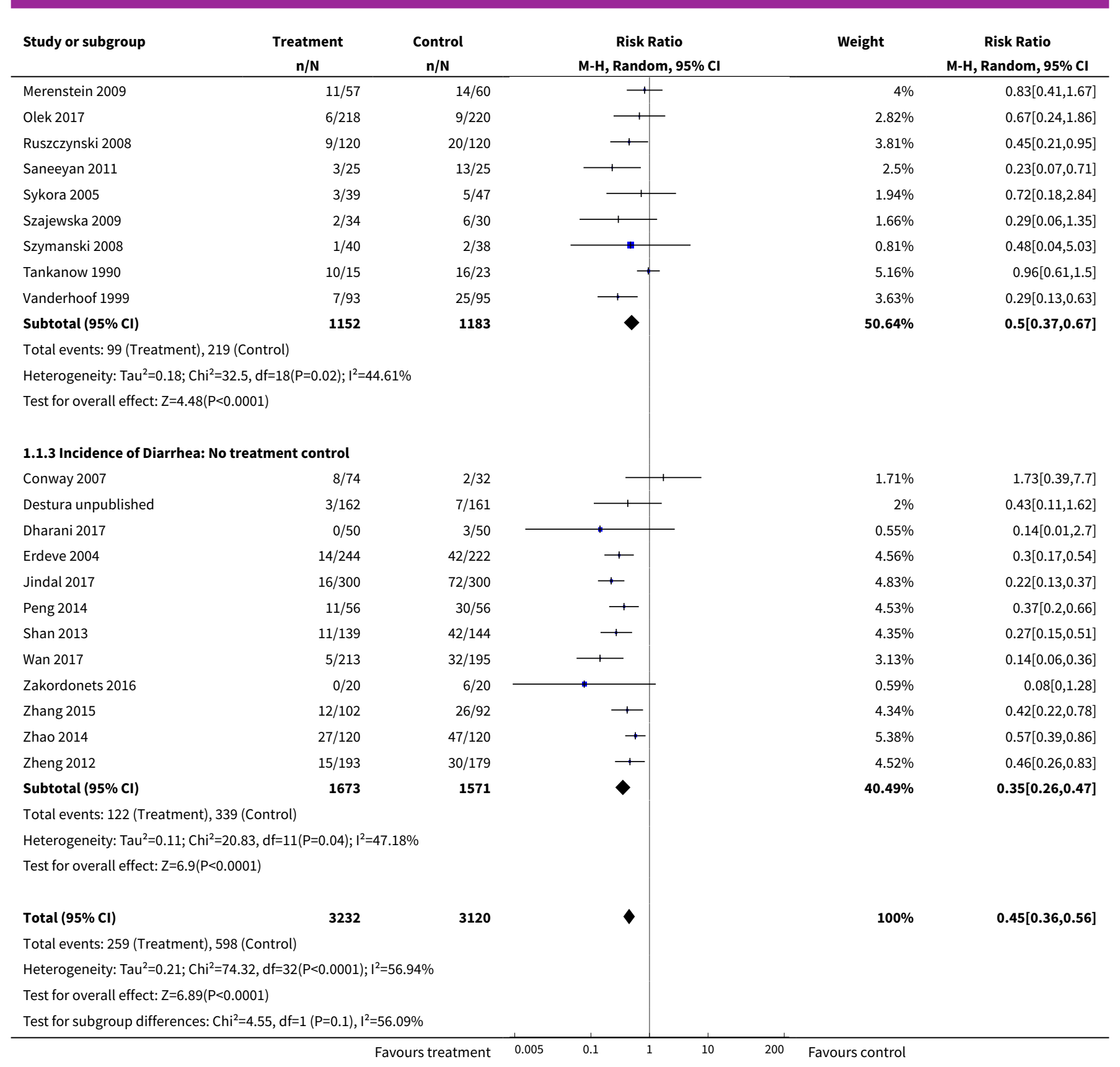

\section{Analysis 1.2. Comparison 1 Probiotics versus control, Outcome 2 Incidence of diarrhea: Inpatient versus outpatient.}

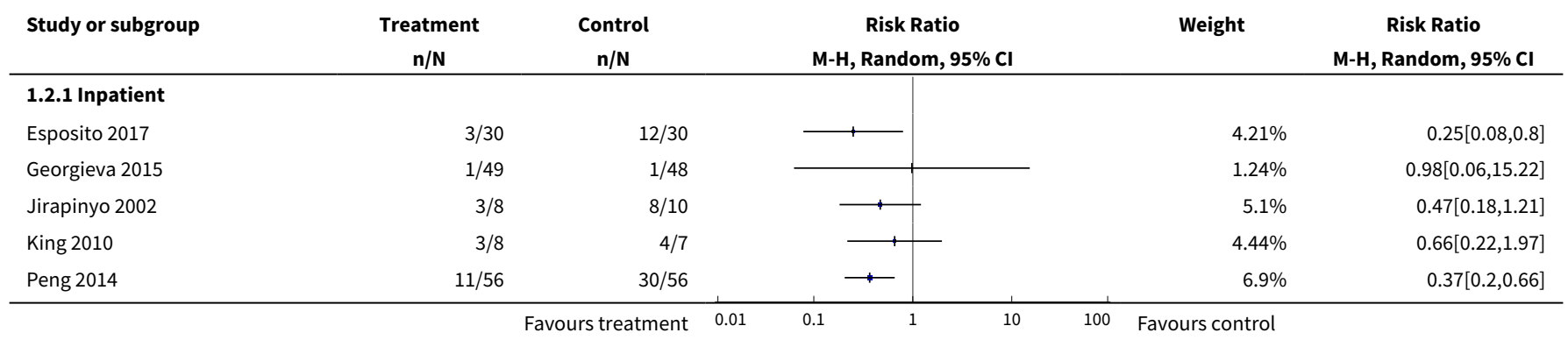




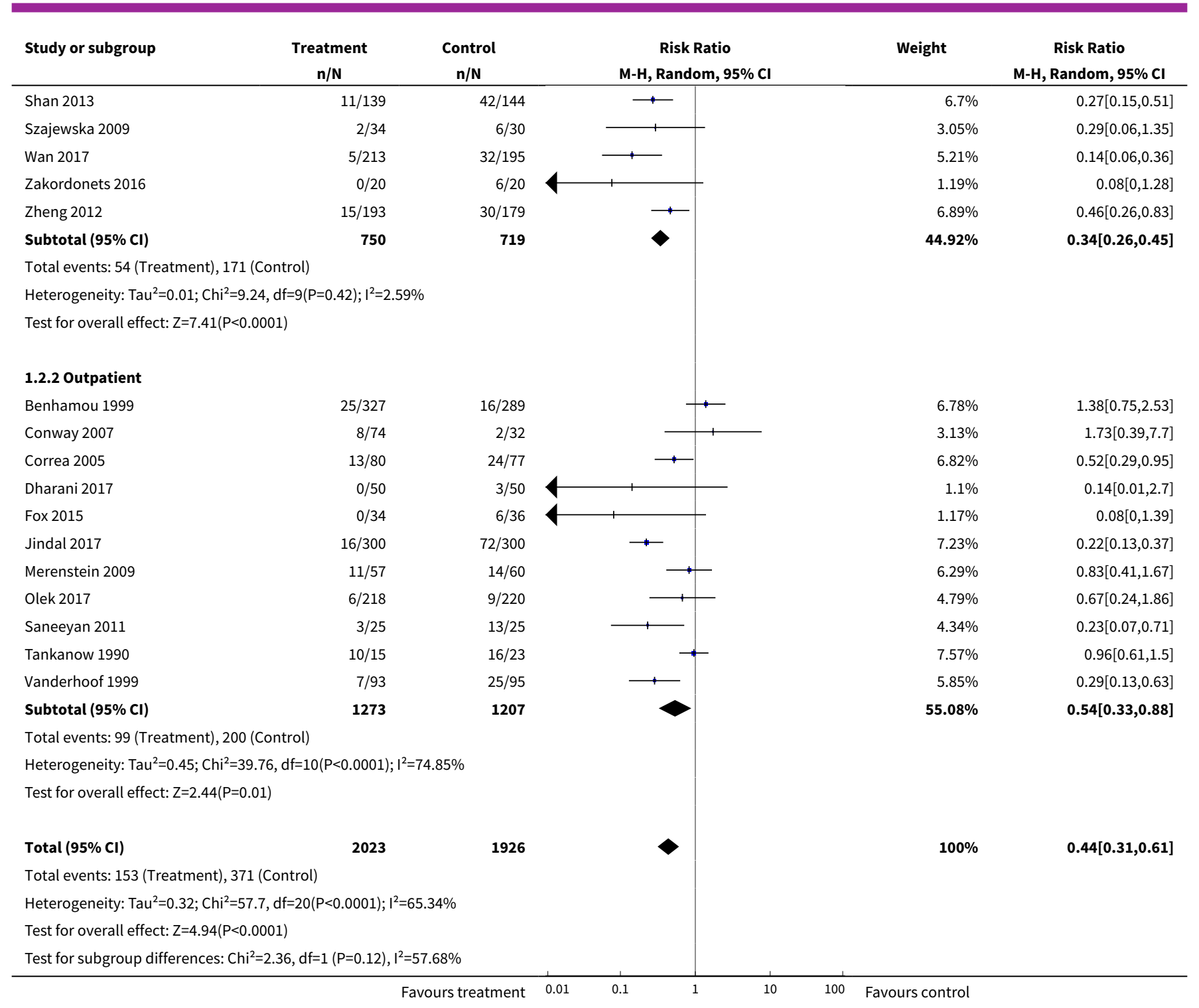

\section{Analysis 1.3. Comparison 1 Probiotics versus control, Outcome 3 Incidence of diarrhea: Diagnosis.}

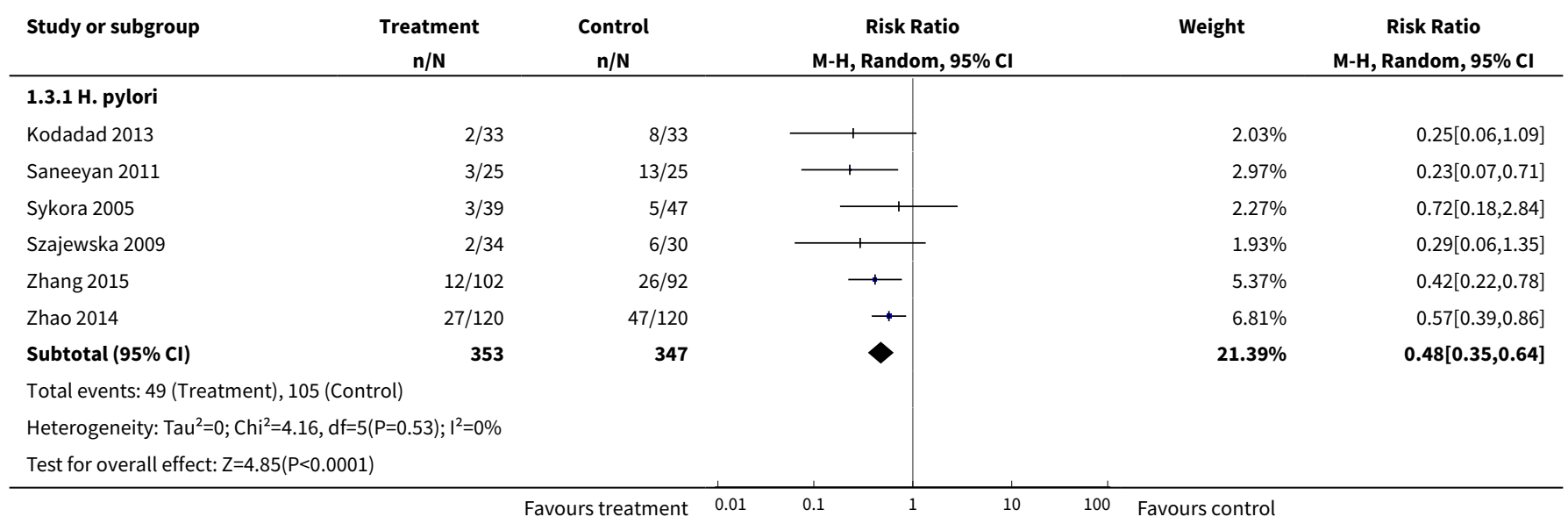




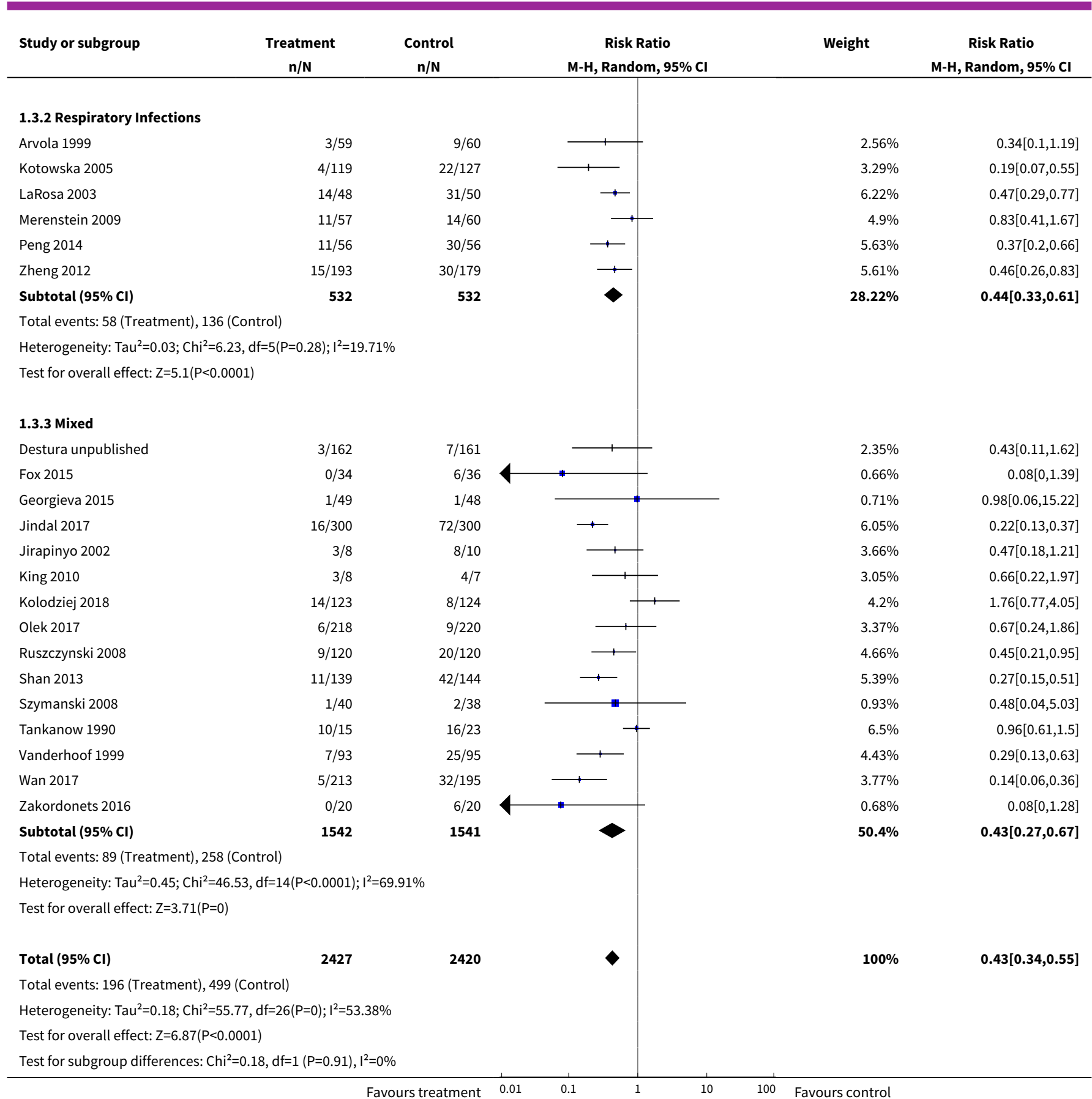

Analysis 1.4. Comparison 1 Probiotics versus control, Outcome 4 Incidence of diarrhea: Probiotic species.

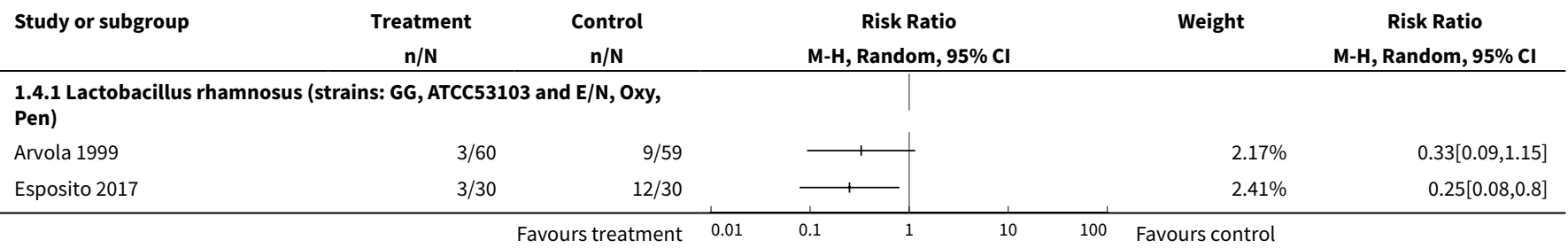




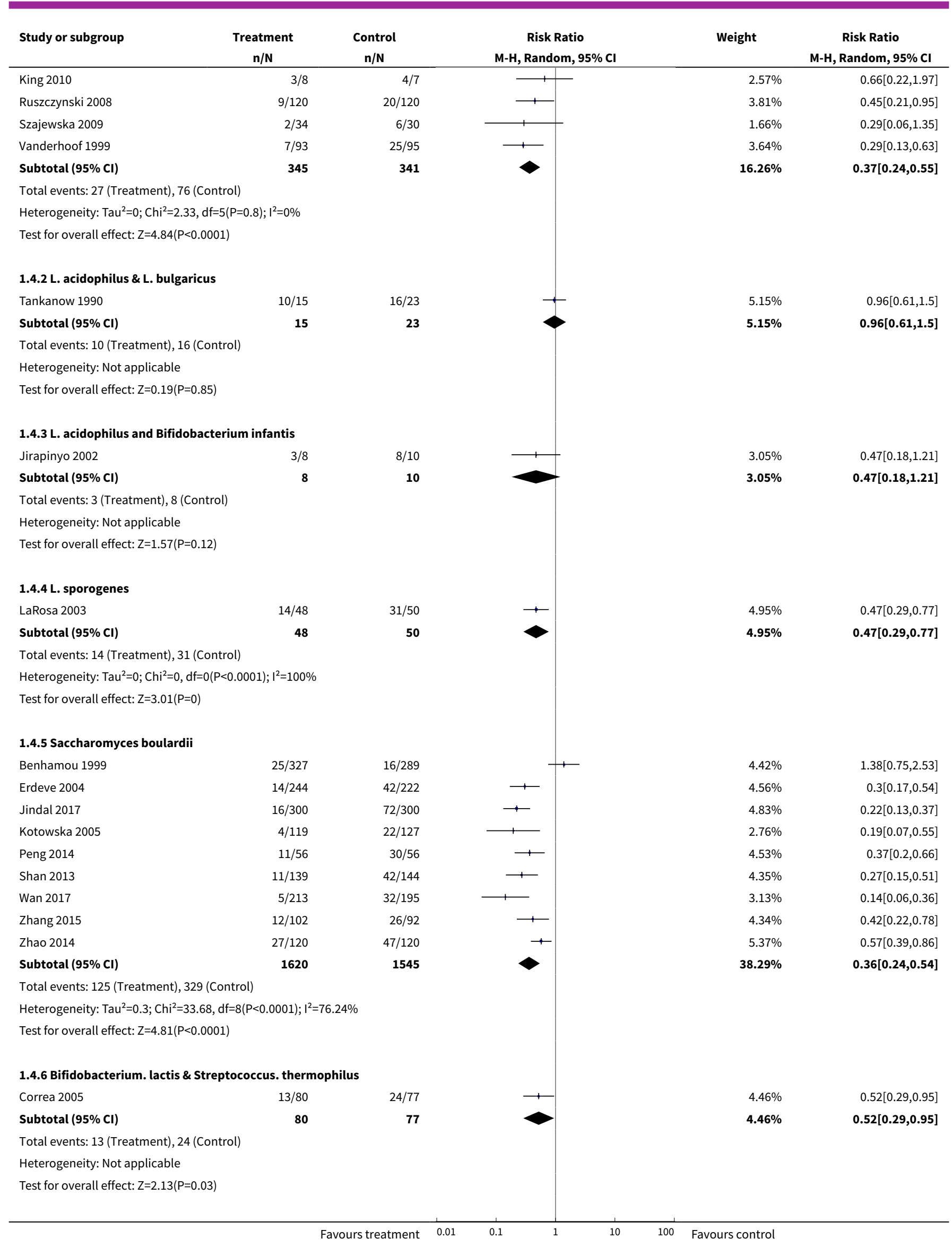




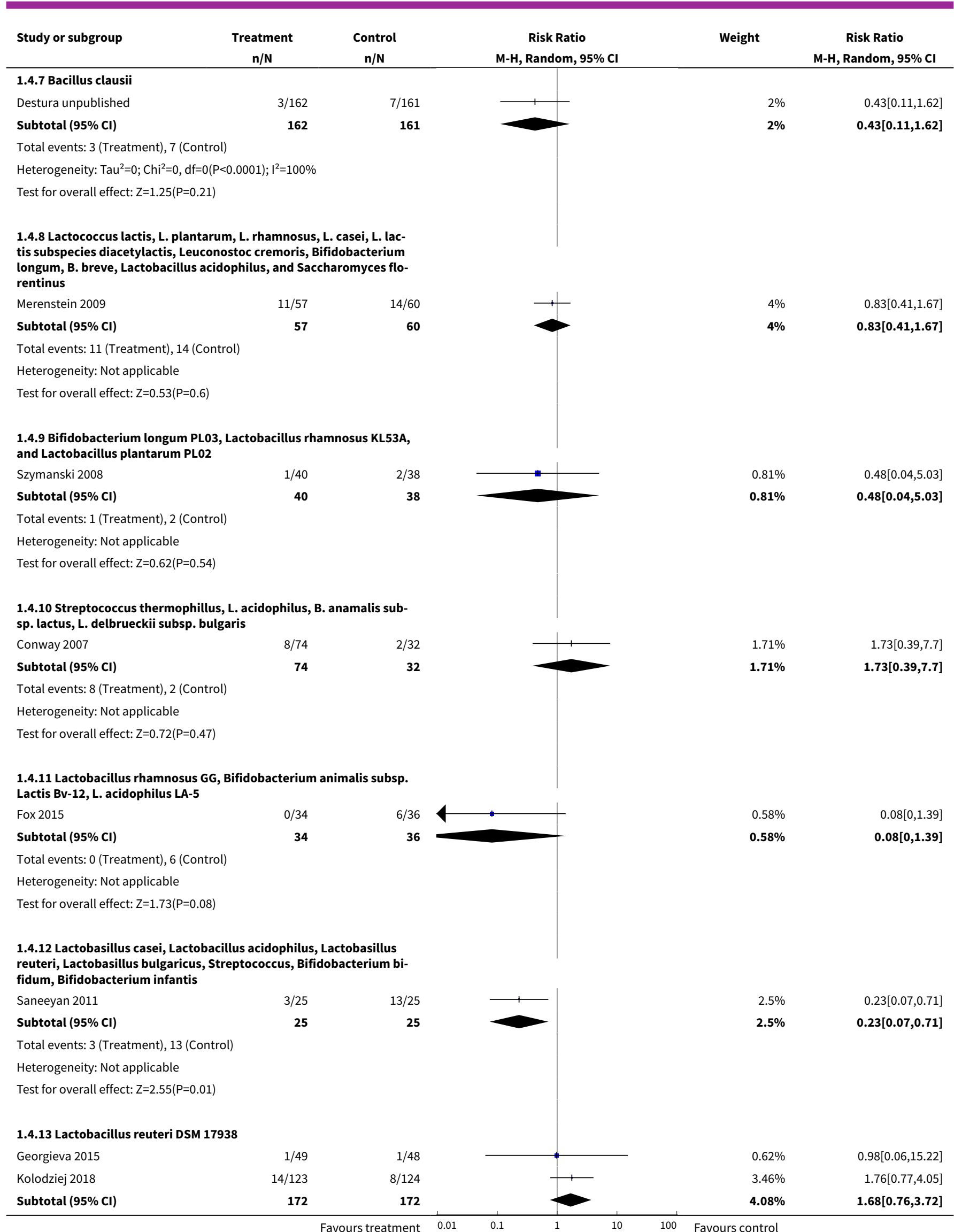




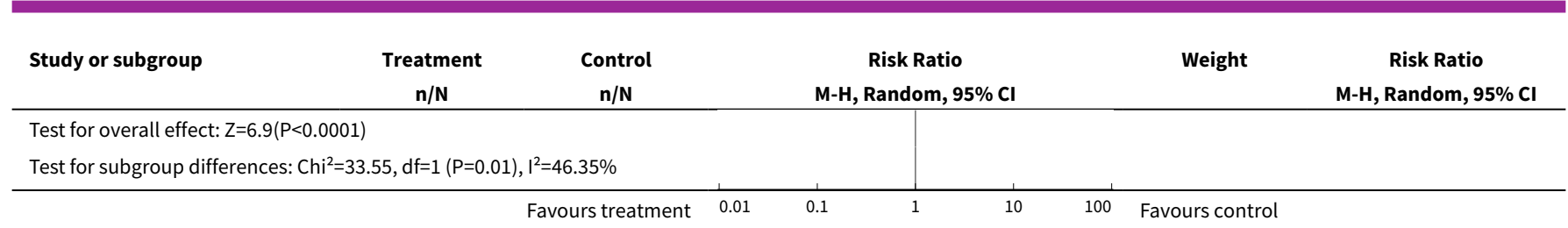

\section{Analysis 1.5. Comparison 1 Probiotics versus control, Outcome 5 Incidence of diarrhea: Single strain versus multi strain.}

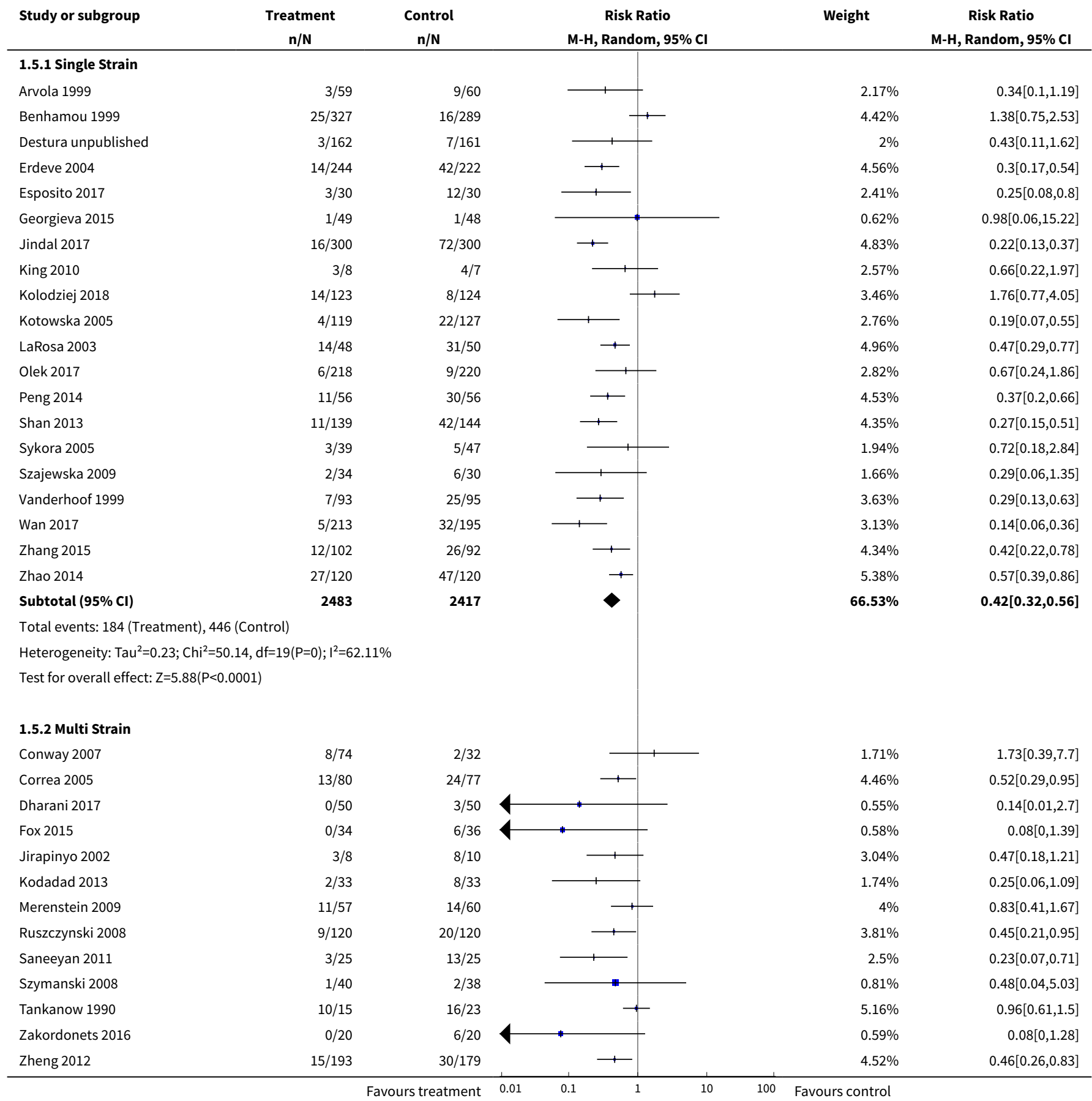




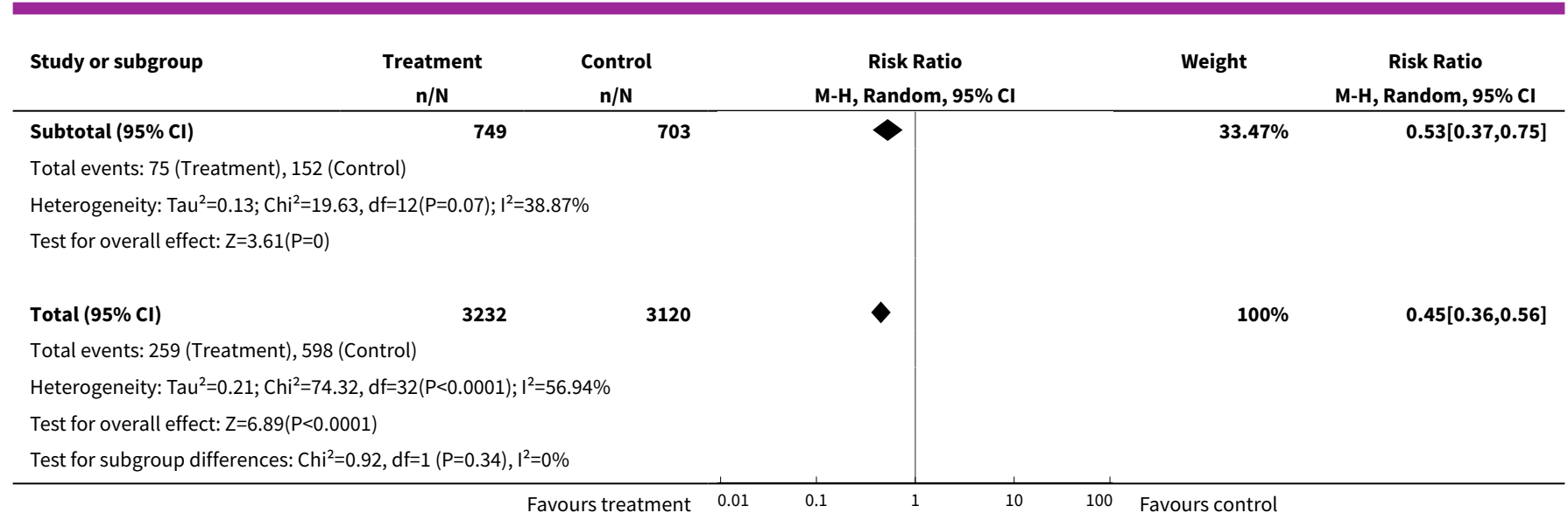

Analysis 1.6. Comparison 1 Probiotics versus control, Outcome 6 Incidence of diarrhea: Probiotic dose.

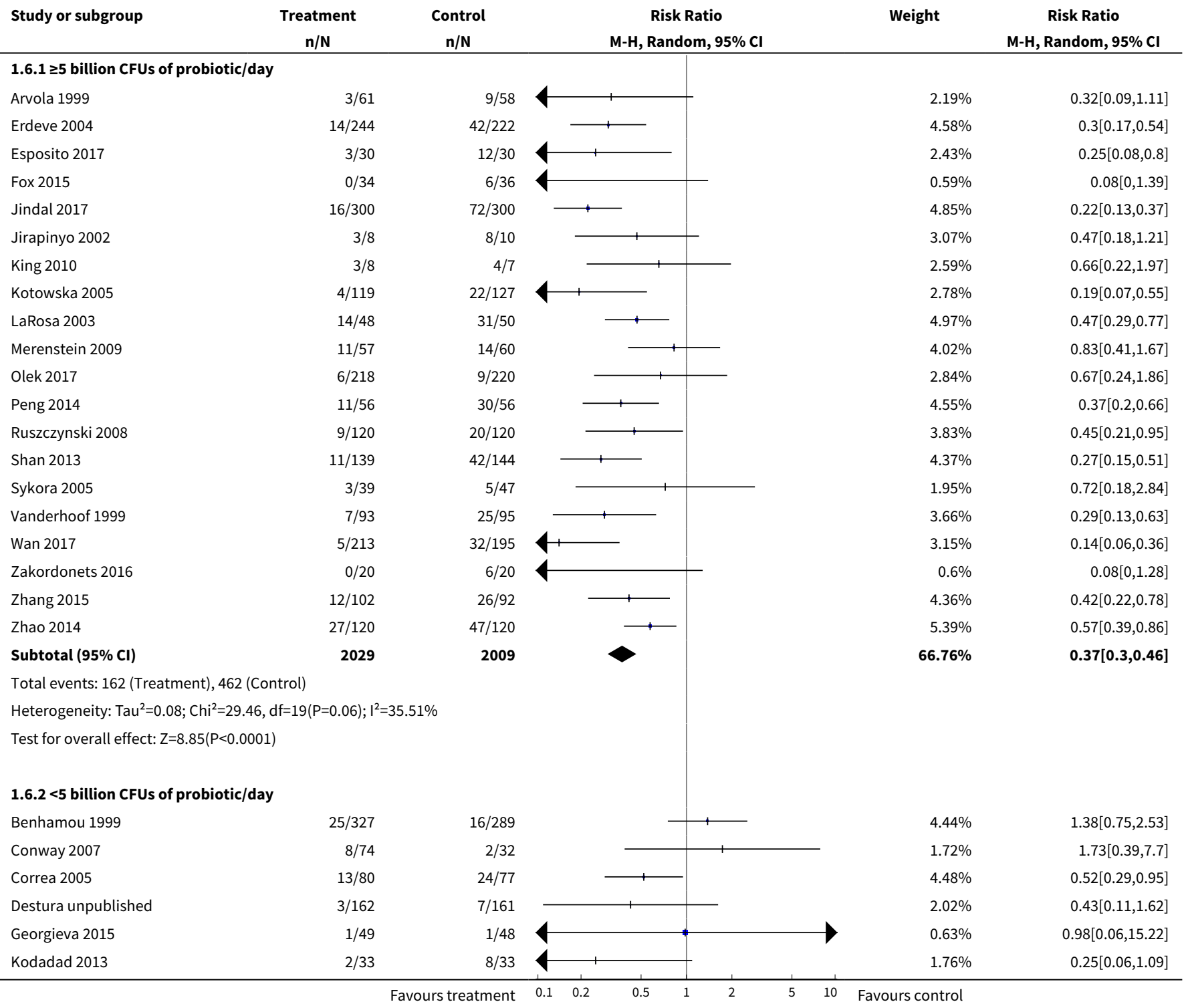




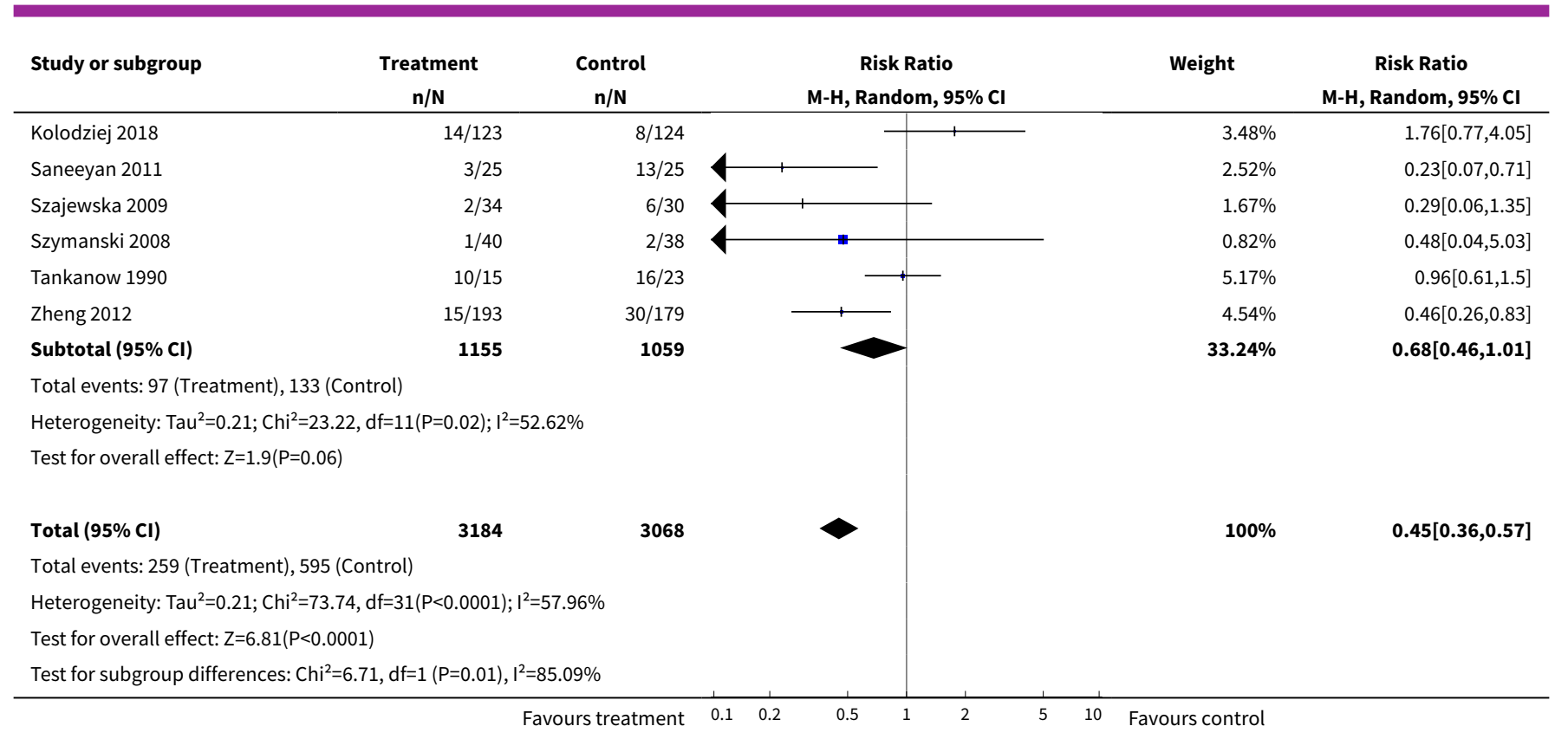

\section{Analysis 1.7. Comparison 1 Probiotics versus control, Outcome 7 Incidence of diarrhea: Definition of diarrhea.}

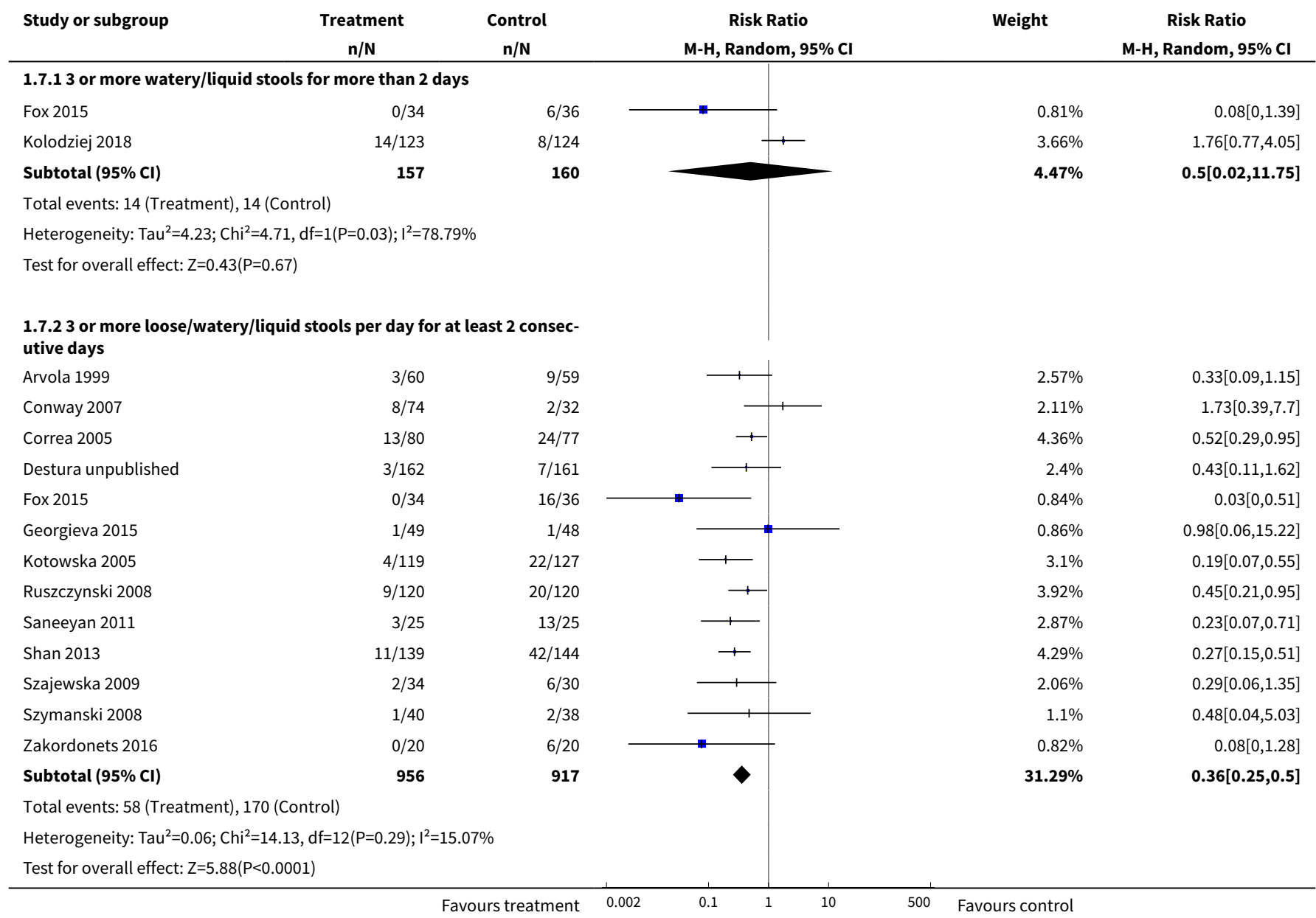




\begin{tabular}{lrr} 
Study or subgroup & $\begin{array}{c}\text { Treatment } \\
\text { n/N }\end{array}$ & $\begin{array}{c}\text { Control } \\
\mathbf{n} / \mathbf{N}\end{array}$ \\
\hline & & \\
$\mathbf{1 . 7 . 3} \geq \mathbf{3}$ watery/liquid stools per $\mathbf{2 4}$ hours & & \\
Benhamou 1999 & $25 / 327$ & $16 / 289$ \\
Erdeve 2004 & $14 / 244$ & $42 / 222$ \\
Esposito 2017 & $3 / 30$ & $12 / 30$ \\
Jindal 2017 & $16 / 300$ & $72 / 300$ \\
King 2010 & $3 / 8$ & $4 / 7$ \\
Kolodziej 2018 & $16 / 123$ & $17 / 124$ \\
Olek 2017 & $6 / 218$ & $9 / 220$ \\
Peng 2014 & $11 / 56$ & $30 / 56$ \\
Zhang 2015 & $12 / 102$ & $26 / 92$ \\
Subtotal (95\% Cl) & $\mathbf{1 4 0 8}$ & $\mathbf{1 3 4 0}$ \\
Total & &
\end{tabular}

Total events: 106 (Treatment), 228 (Control)

Heterogeneity: $\mathrm{Tau}^{2}=0.33 ; \mathrm{Chi}^{2}=29.98, \mathrm{df}=8(\mathrm{P}=0) ; \mathrm{I}^{2}=73.32 \%$

Test for overall effect: $Z=3.16(P=0)$

\subsection{4 $\geq 2$ liquid stools per day on at least 2 occasions during study}

Fox 2015

Vanderhoof 1999

$0 / 34$

Subtotal $(95 \% \mathrm{Cl})$

$7 / 93$

127

Total events: 7 (Treatment), 33 (Control)

Heterogeneity: $\mathrm{Tau}^{2}=0.14 ; \mathrm{Chi}^{2}=1.12, \mathrm{df}=1(\mathrm{P}=0.29) ; \mathrm{I}^{2}=11.03 \%$

Test for overall effect: $\mathrm{Z}=2.79(\mathrm{P}=0.01)$

\subsection{5 $\geq 2$ loose/watery/liquid stools for more than $\mathbf{2}$ days}

Fox 2015

$1 / 34$

Wan 2017

$5 / 213$

Subtotal $(95 \% \mathrm{CI})$

247

$21 / 36$

$32 / 195$

231

Total events: 6 (Treatment), 53 (Control)

Heterogeneity: $\mathrm{Tau}^{2}=0 ; \mathrm{Chi}^{2}=0.94, \mathrm{df}=1(\mathrm{P}=0.33) ; \mathrm{I}^{2}=0 \%$

Test for overall effect: $Z=5.02(P<0.0001)$

\subsection{6 $\geq 2$ liquid stools per $24 \mathrm{hr}$}

Kolodziej 2018

LaRosa 2003

$16 / 123$

$14 / 48$

171

$17 / 124$

$31 / 50$

Subtotal $(95 \% \mathrm{Cl})$

Total events: 30 (Treatment), 48 (Control)

Heterogeneity: $\mathrm{Tau}^{2}=0.17 ; \mathrm{Chi}^{2}=2.99, \mathrm{df}=1(\mathrm{P}=0.08) ; \mathrm{I}^{2}=66.54 \%$

Test for overall effect: $Z=1.23(P=0.22)$

1.7.7 $\geq 1$ abnormally loose bowel movement per $24 \mathrm{hrs}$

Tankanow 1990

$10 / 15$

Subtotal $(95 \% \mathrm{Cl})$

15

$16 / 23$

Total events: 10 (Treatment), 16 (Control)

Heterogeneity: Not applicable

Test for overall effect: $Z=0.19(P=0.85)$

1.7.8 2 or more BM over the patient's normal

Zheng 2012

$15 / 193$

193

Subtotal $(95 \% \mathrm{Cl})$

Total events: 15 (Treatment), 30 (Control)

Heterogeneity: Not applicable
$8 / 36$

Risk Ratio

M-H, Random, 95\% CI

289
222
$/ 30$
$4 / 7$
124
220
156
$16 / 92$
340

Risk Ratio

M-H, Random, 95\% Cl

$1.38[0.75,2.53]$

$0.3[0.17,0.54]$

$0.25[0.08,0.8]$

$0.22[0.13,0.37]$

$0.66[0.22,1.97]$

$0.95[0.5,1.79]$

$0.67[0.24,1.86]$

$0.37[0.2,0.66]$

$0.42[0.22,0.78]$

$0.48[0.31,0.76]$

$0.06[0,1.04]$

$0.82 \%$

$0.29[0.13,0.63]$

$\mathbf{4 . 6 1 \%}$

$0.24[0.09,0.65]$

$0.05[0.01,0.35]$

$0.14[0.06,0.36]$

$0.12[0.05,0.27]$

$0.95[0.5,1.79]$

$0.47[0.29,0.77]$

$0.65[0.32,1.3]$ 


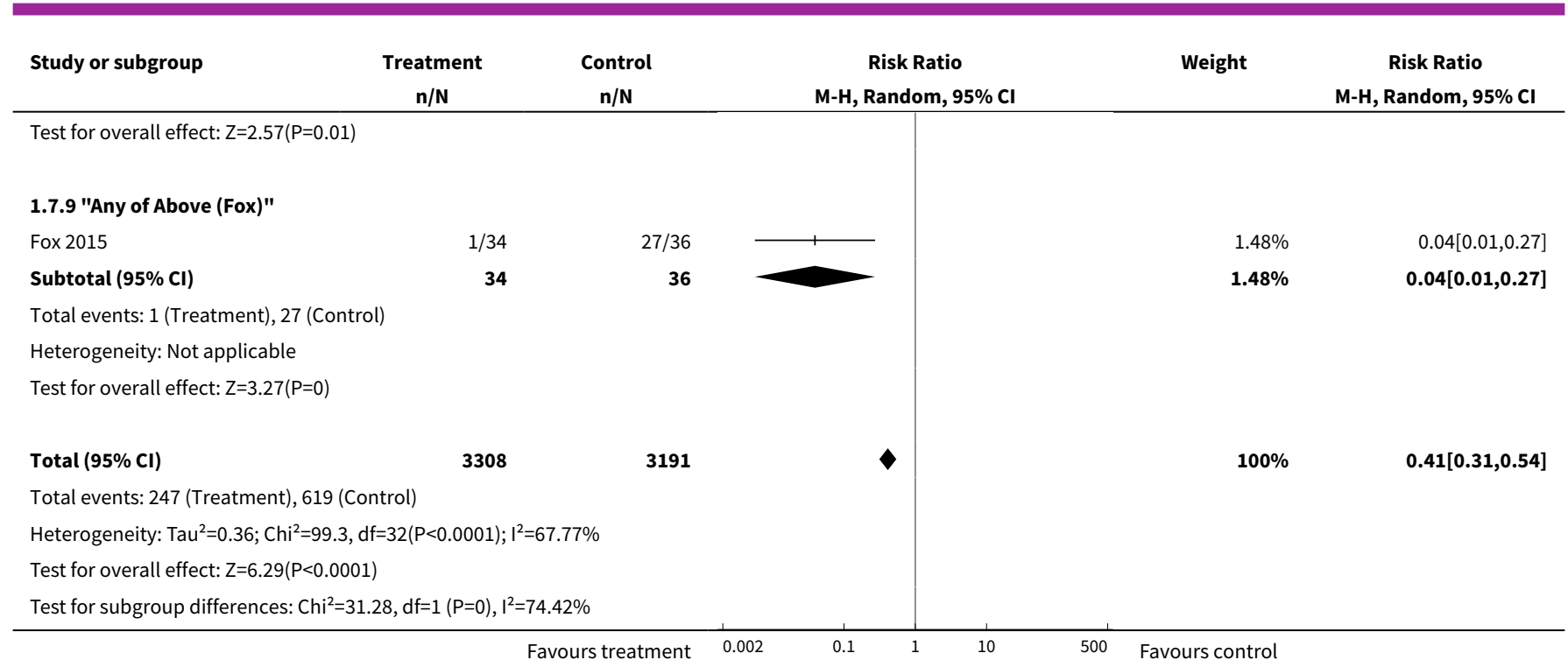

Analysis 1.8. Comparison 1 Probiotics versus control, Outcome 8 Incidence of diarrhea: Strictness of definition (mild vs moderate).

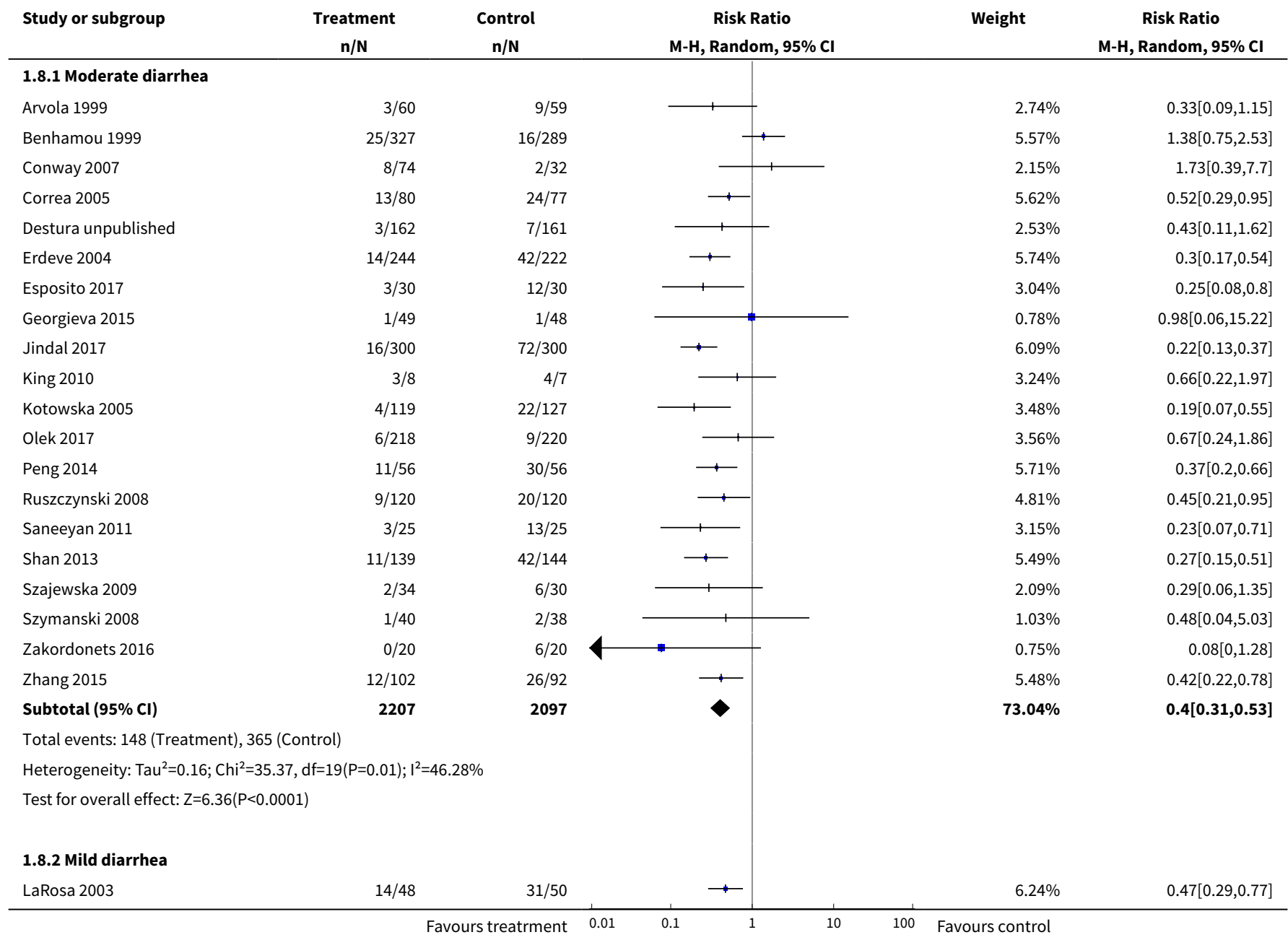




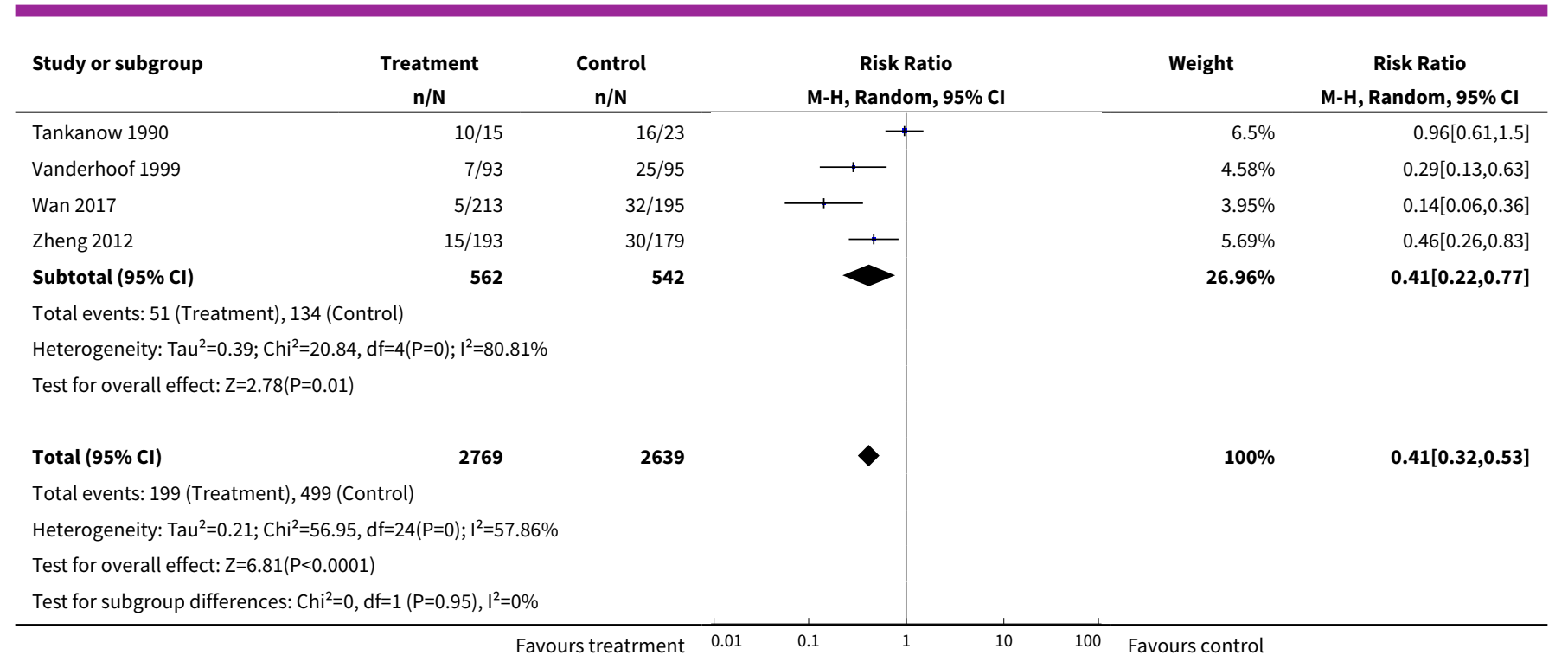

Analysis 1.9. Comparison 1 Probiotics versus control, Outcome 9 Incidence of diarrhea: Industry sponsorship.

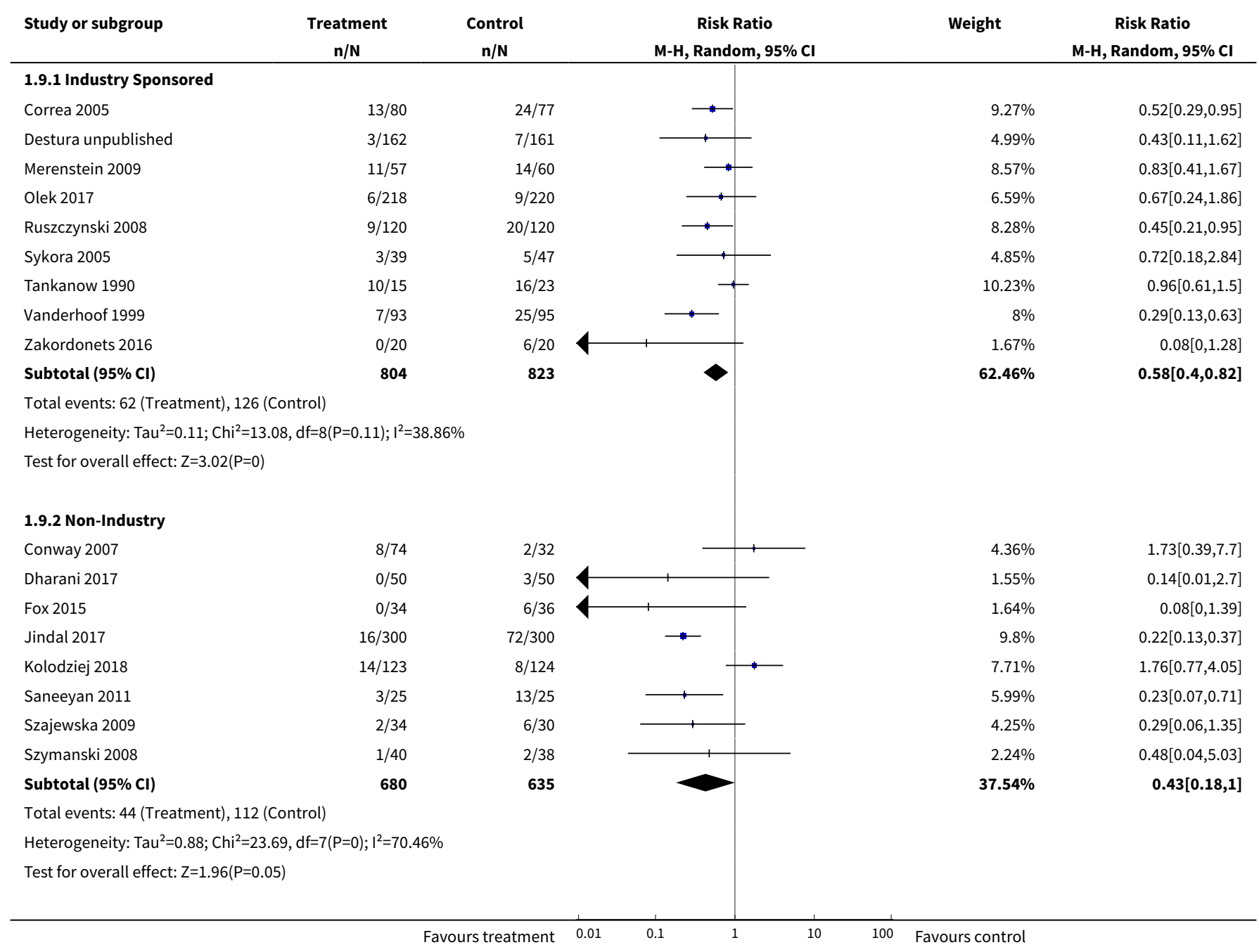




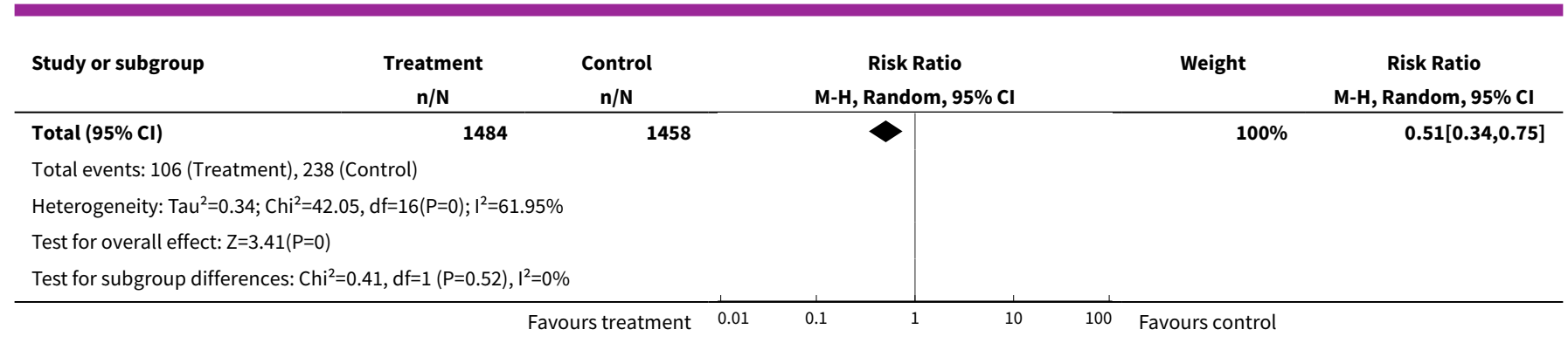

Analysis 1.10. Comparison 1 Probiotics versus control, Outcome 10 Incidence of diarrhea: Risk of bias.

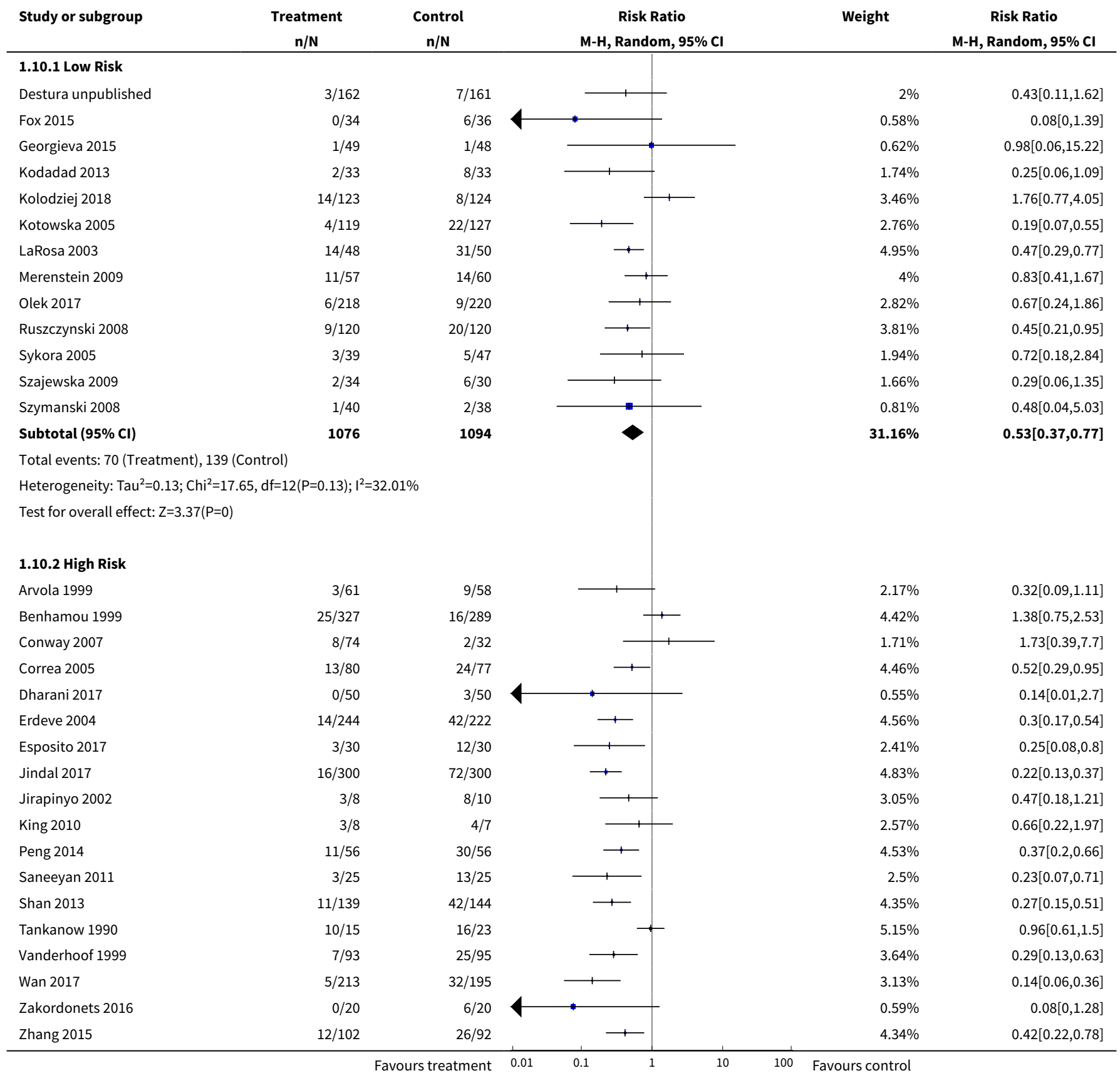




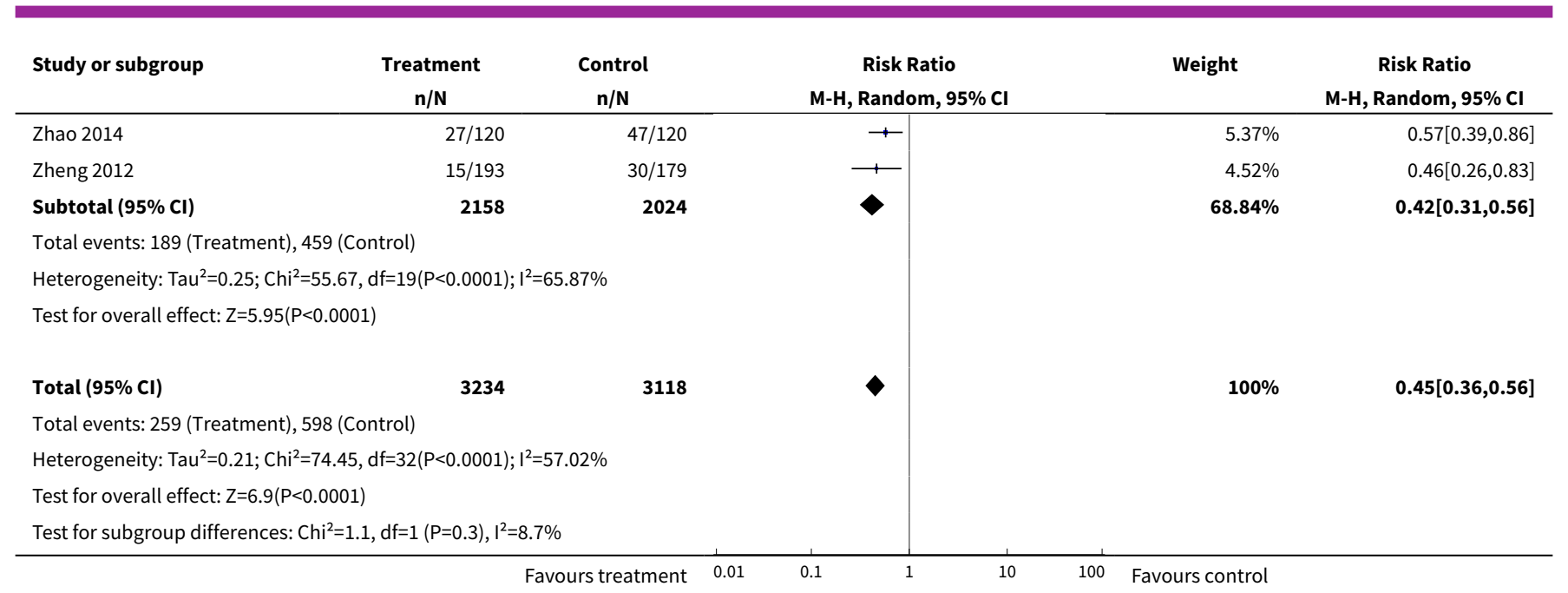

Analysis 1.11. Comparison 1 Probiotics versus control, Outcome 11 Incidence of diarrhea: age.

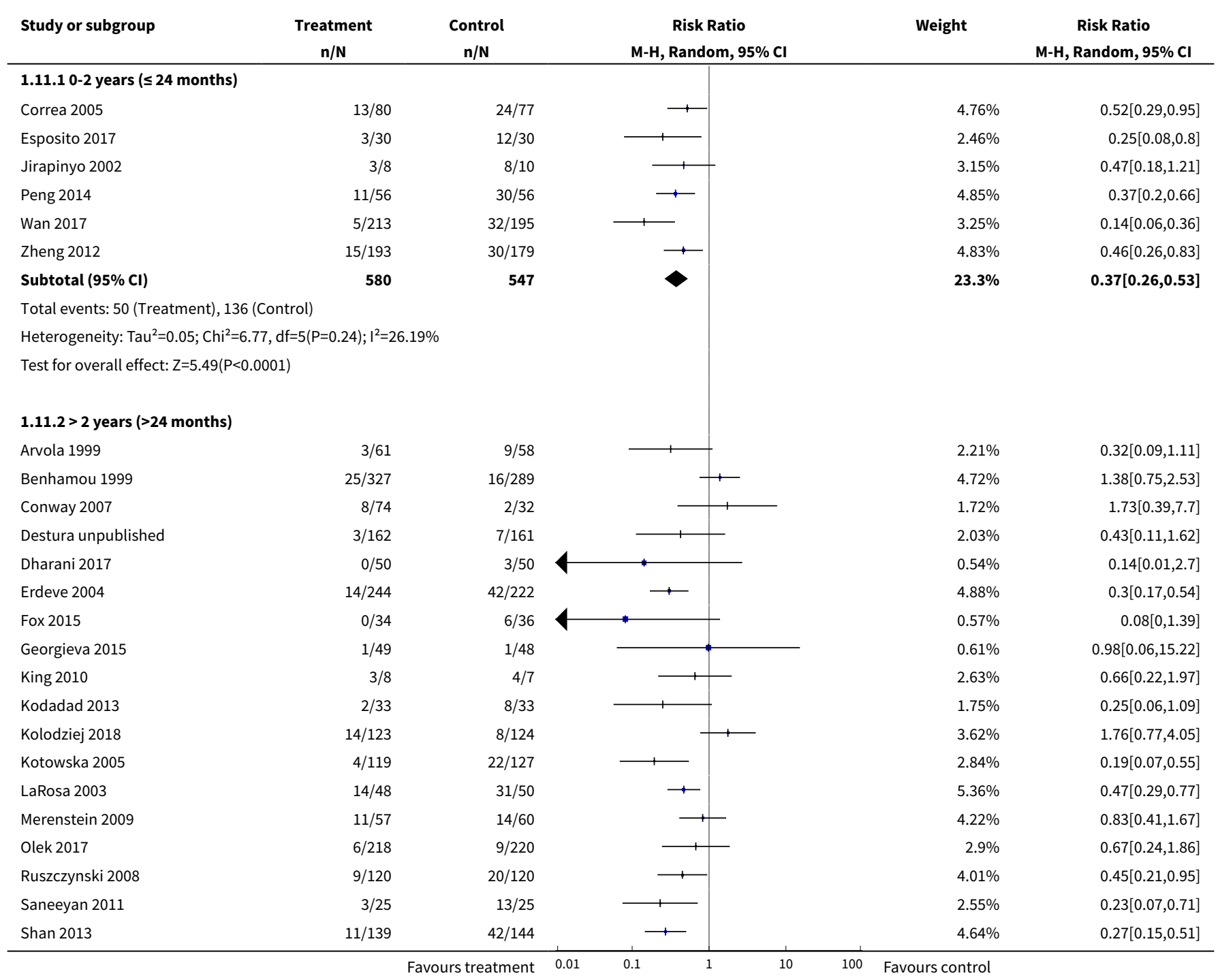




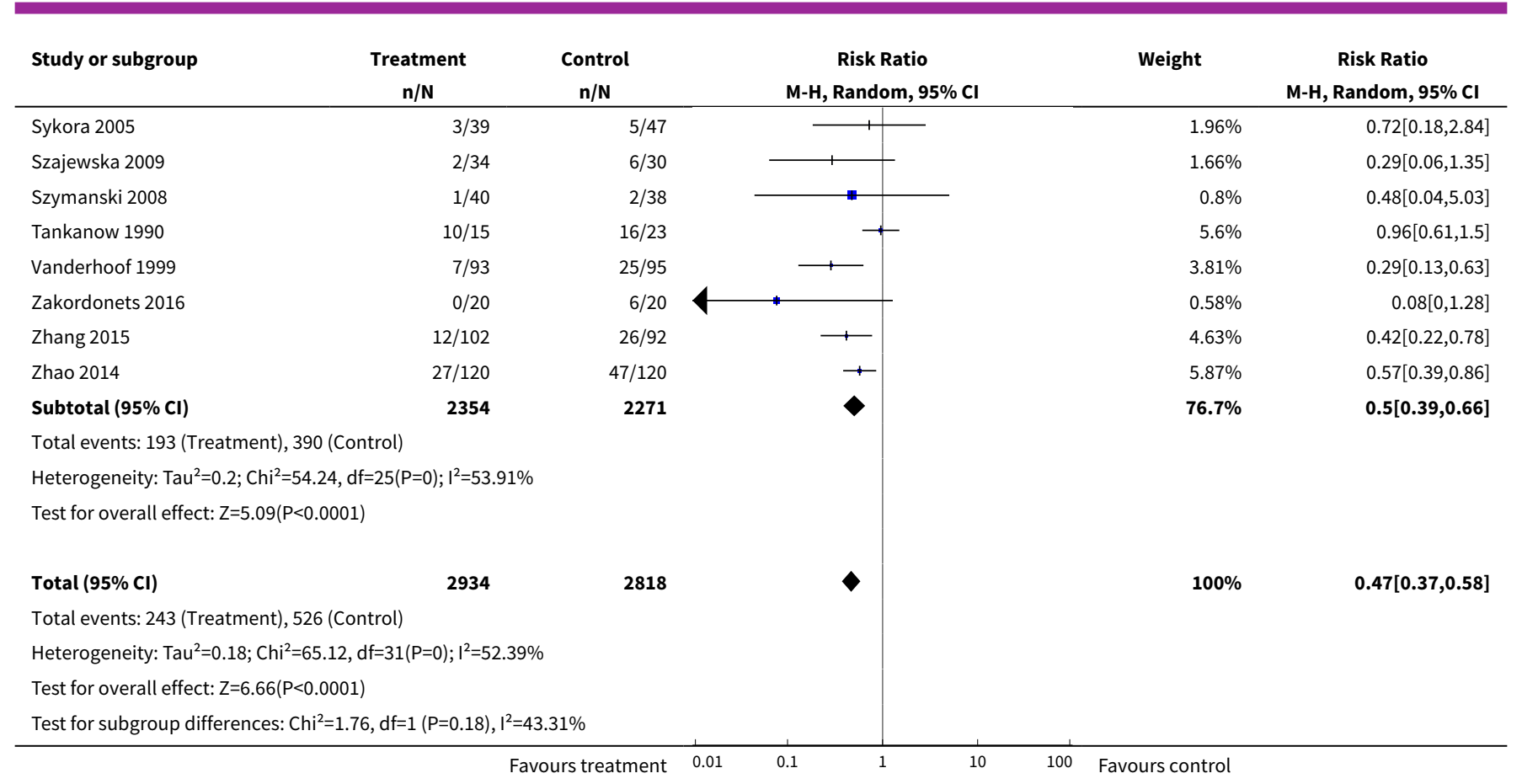

Analysis 1.12. Comparison 1 Probiotics versus control, Outcome 12 Incidence of diarrhea: Sensitivity analysis (complete case - fixed effects).

\begin{tabular}{|c|c|c|c|c|c|c|}
\hline Study or subgroup & $\begin{array}{c}\text { Treatment } \\
\mathrm{n} / \mathrm{N} \\
\end{array}$ & $\begin{array}{c}\text { Control } \\
n / N\end{array}$ & $\begin{array}{r}\text { Risk } \\
\text { M-H, Fixe } \\
\end{array}$ & $\begin{array}{l}\text { Ratio } \\
\text { d, } 95 \% \mathrm{Cl}\end{array}$ & Weight & $\begin{array}{c}\text { Risk Ratio } \\
\text { M-H, Fixed, 95\% Cl }\end{array}$ \\
\hline \multicolumn{7}{|c|}{ 1.12.1 Active controlled } \\
\hline Benhamou 1999 & $25 / 327$ & $16 / 289$ & & 1 & $2.83 \%$ & $1.38[0.75,2.53]$ \\
\hline Correa 2005 & $13 / 80$ & $24 / 77$ & $\longrightarrow$ & & $4.07 \%$ & $0.52[0.29,0.95]$ \\
\hline Subtotal $(95 \% \mathrm{Cl})$ & 407 & 366 & & & $6.9 \%$ & $0.87[0.58,1.32]$ \\
\hline \multicolumn{7}{|c|}{ Total events: 38 (Treatment), 40 (Control) } \\
\hline \multicolumn{7}{|c|}{ Test for overall effect: $Z=0.64(P=0.52)$} \\
\hline \multicolumn{7}{|c|}{ 1.12.2 Placebo controlled } \\
\hline Arvola 1999 & $3 / 59$ & $9 / 60$ & & + & $1.49 \%$ & $0.34[0.1,1.19]$ \\
\hline Esposito 2017 & $3 / 30$ & $12 / 30$ & 1 & & $2 \%$ & $0.25[0.08,0.8]$ \\
\hline Fox 2015 & $0 / 34$ & $6 / 36$ & & - & $1.05 \%$ & $0.08[0,1.39]$ \\
\hline Jirapinyo 2002 & $3 / 8$ & $8 / 10$ & 1 & & $1.18 \%$ & $0.47[0.18,1.21]$ \\
\hline King 2010 & $3 / 8$ & $4 / 7$ & & - & $0.71 \%$ & $0.66[0.22,1.97]$ \\
\hline Kodadad 2013 & $2 / 33$ & $8 / 33$ & & & $1.33 \%$ & $0.25[0.06,1.09]$ \\
\hline Kolodziej 2018 & $14 / 123$ & $8 / 124$ & & 1 & $1.33 \%$ & $1.76[0.77,4.05]$ \\
\hline Kotowska 2005 & $4 / 119$ & $22 / 127$ & & & $3.54 \%$ & $0.19[0.07,0.55]$ \\
\hline LaRosa 2003 & $14 / 48$ & $31 / 50$ & 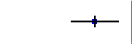 & & $5.06 \%$ & $0.47[0.29,0.77]$ \\
\hline Merenstein 2009 & $11 / 57$ & $14 / 60$ & & - & $2.27 \%$ & $0.83[0.41,1.67]$ \\
\hline Olek 2017 & $6 / 218$ & $9 / 220$ & & - & $1.49 \%$ & $0.67[0.24,1.86]$ \\
\hline Ruszczynski 2008 & $9 / 120$ & $20 / 120$ & 1 & & $3.33 \%$ & $0.45[0.21,0.95]$ \\
\hline Saneeyan 2011 & $3 / 25$ & $13 / 25$ & 1 & & $2.16 \%$ & $0.23[0.07,0.71]$ \\
\hline Sykora 2005 & $3 / 39$ & $5 / 47$ & $\longrightarrow$ & & $0.76 \%$ & $0.72[0.18,2.84]$ \\
\hline
\end{tabular}




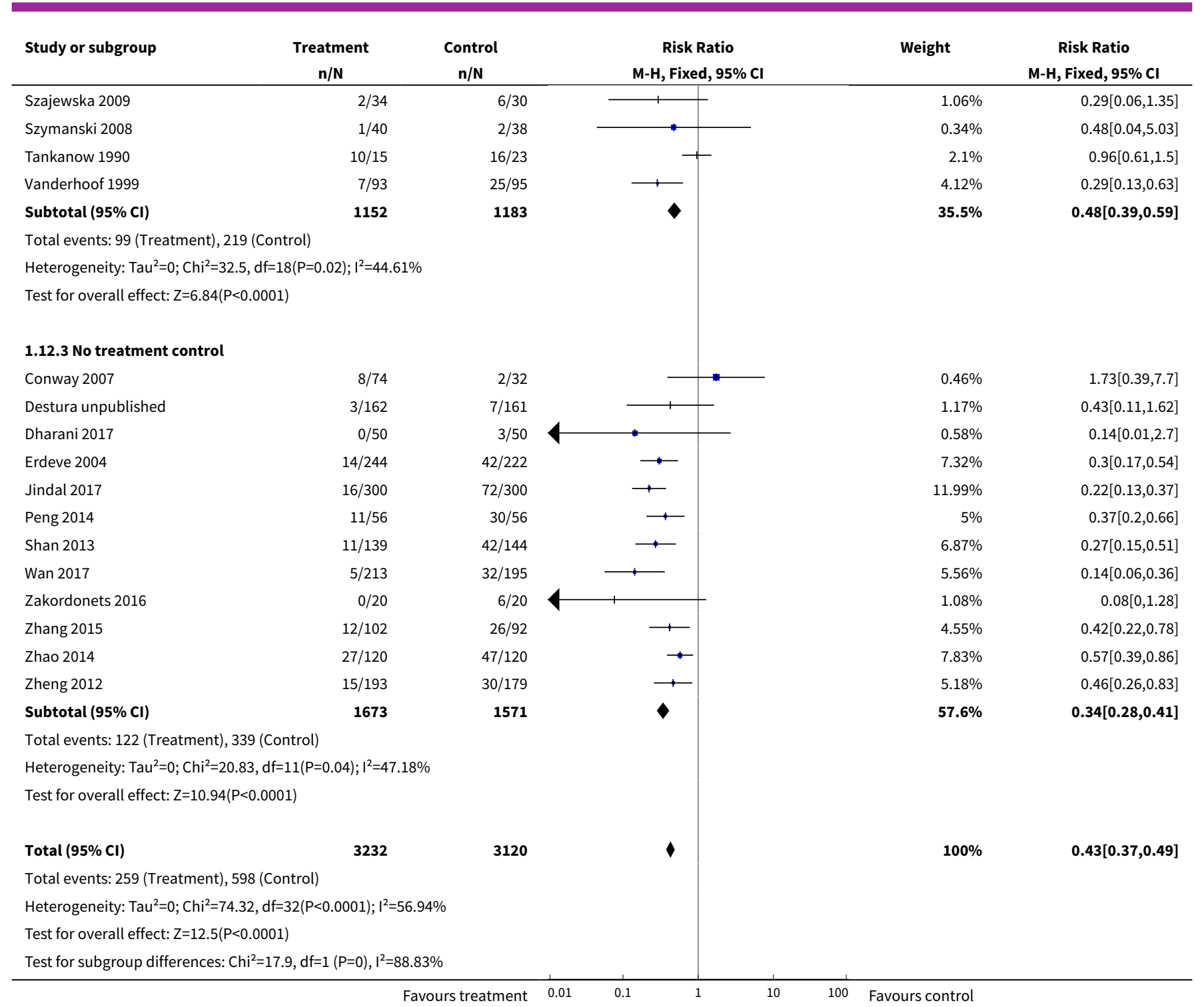

Analysis 1.13. Comparison 1 Probiotics versus control, Outcome 13 Incidence of diarrhea: Probiotic dose (extreme-plausible analysis).

\begin{tabular}{|c|c|c|c|c|c|}
\hline Study or subgroup & $\begin{array}{c}\text { Treatment } \\
\mathrm{n} / \mathrm{N}\end{array}$ & $\begin{array}{c}\text { Control } \\
n / N\end{array}$ & $\begin{array}{c}\text { Risk Ratio } \\
\text { M-H, Random, } 95 \% \mathrm{Cl}\end{array}$ & Weight & $\begin{array}{c}\text { Risk Ratio } \\
\text { M-H, Random, } 95 \% \mathrm{CI}\end{array}$ \\
\hline \multicolumn{6}{|c|}{ 1.13.1 $\geq 5$ billion CFUs of probiotic/day } \\
\hline Arvola 1999 & $20 / 88$ & $13 / 79$ & $\longrightarrow$ & $3.81 \%$ & $1.38[0.74,2.59]$ \\
\hline Erdeve 2004 & $63 / 326$ & $63 / 327$ & + & $4.84 \%$ & $1[0.73,1.37]$ \\
\hline Esposito 2017 & $3 / 30$ & $12 / 30$ & 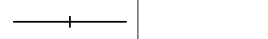 & $2.26 \%$ & $0.25[0.08,0.8]$ \\
\hline Fox 2015 & $1 / 36$ & $6 / 36$ & & $1 \%$ & $0.17[0.02,1.32]$ \\
\hline Jirapinyo 2002 & $3 / 8$ & $8 / 10$ & 1 & $2.8 \%$ & $0.47[0.18,1.21]$ \\
\hline King 2010 & $7 / 15$ & $5 / 13$ & 1 & $3 \%$ & $1.21[0.51,2.91]$ \\
\hline Kotowska 2005 & $12 / 132$ & $24 / 137$ & 1 & $3.73 \%$ & $0.52[0.27,0.99]$ \\
\hline LaRosa 2003 & $21 / 60$ & $33 / 60$ & + & $4.54 \%$ & $0.64[0.42,0.96]$ \\
\hline
\end{tabular}




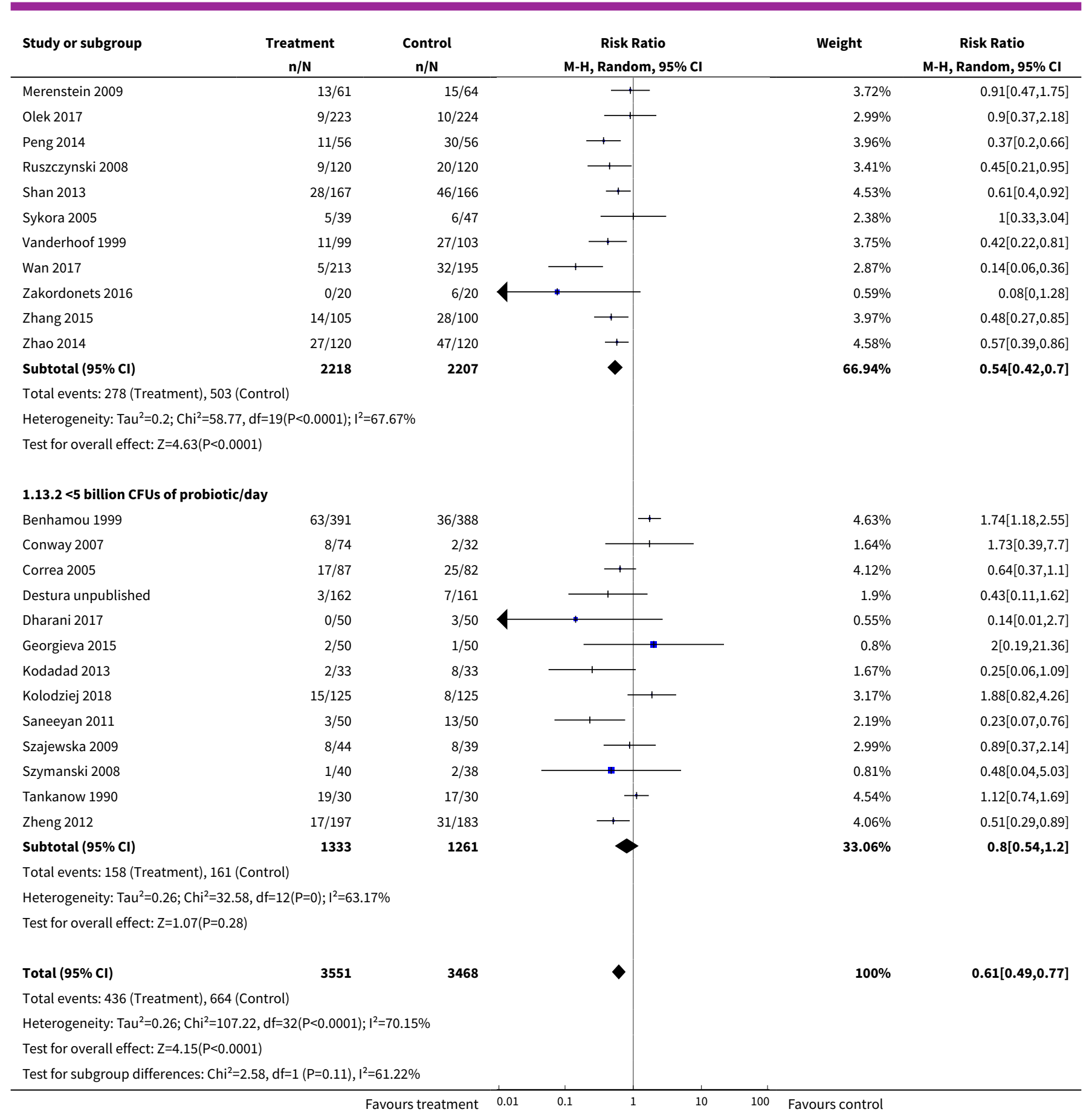

Analysis 1.14. Comparison 1 Probiotics versus control, Outcome 14 Incidence of diarrhea: Sensitivity analysis (missing outcome data - extreme plausible analysis).

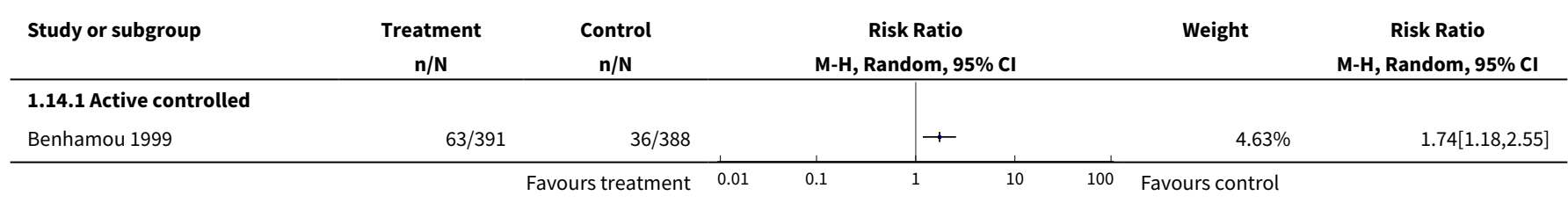




\begin{tabular}{|c|c|c|c|c|c|c|c|c|}
\hline \multirow{2}{*}{$\begin{array}{l}\text { Study or subgroup } \\
\text { Correa } 2005\end{array}$} & \multirow{2}{*}{$\begin{array}{l}\text { Treatment } \\
\qquad \mathbf{n / N} \\
17 / 87\end{array}$} & \multirow{2}{*}{$\begin{array}{l}\begin{array}{l}\text { Control } \\
\mathbf{n} / \mathbf{N}\end{array} \\
25 / 82\end{array}$} & \multicolumn{3}{|c|}{$\begin{array}{c}\text { Risk Ratio } \\
\text { M-H, Random, 95\% Cl }\end{array}$} & \multicolumn{2}{|r|}{ Weight } & \multirow{2}{*}{$\begin{array}{c}\text { Risk Ratio } \\
\text { M-H, Random, 95\% Cl }\end{array}$} \\
\hline & & & & & & & $4.12 \%$ & \\
\hline Subtotal $(95 \% \mathrm{Cl})$ & 478 & 470 & & & & & $8.76 \%$ & $1.07[0.4,2.86]$ \\
\hline \multicolumn{9}{|c|}{ Total events: 80 (Treatment), 61 (Control) } \\
\hline \multicolumn{9}{|c|}{ Heterogeneity: $\mathrm{Tau}^{2}=0.44 ; \mathrm{Chi}^{2}=8.79, \mathrm{df}=1(\mathrm{P}=0) ; \mathrm{I}^{2}=88.62 \%$} \\
\hline \multicolumn{9}{|c|}{ Test for overall effect: $Z=0.14(P=0.89)$} \\
\hline \multicolumn{9}{|c|}{ 1.14.2 Placebo controlled } \\
\hline Arvola 1999 & $20 / 88$ & $13 / 79$ & & & - & & $3.81 \%$ & $1.38[0.74,2.59]$ \\
\hline Esposito 2017 & $3 / 30$ & $12 / 30$ & & - & & & $2.26 \%$ & $0.25[0.08,0.8]$ \\
\hline Fox 2015 & $1 / 36$ & $6 / 36$ & & & - & & $1 \%$ & $0.17[0.02,1.32]$ \\
\hline Georgieva 2015 & $2 / 50$ & $1 / 50$ & & & $\rightarrow$ & & $0.8 \%$ & $2[0.19,21.36]$ \\
\hline Jirapinyo 2002 & $3 / 8$ & $8 / 10$ & & & - & & $2.8 \%$ & $0.47[0.18,1.21]$ \\
\hline King 2010 & $7 / 15$ & $5 / 13$ & & & 1 & & $3 \%$ & $1.21[0.51,2.91]$ \\
\hline Kodadad 2013 & $2 / 33$ & $8 / 33$ & & & & & $1.67 \%$ & $0.25[0.06,1.09]$ \\
\hline Kolodziej 2018 & $15 / 125$ & $8 / 125$ & & & 1 & & $3.17 \%$ & $1.88[0.82,4.26]$ \\
\hline Kotowska 2005 & $12 / 132$ & $24 / 137$ & & - & & & $3.73 \%$ & $0.52[0.27,0.99]$ \\
\hline LaRosa 2003 & $21 / 60$ & $33 / 60$ & & $\leftarrow$ & & & $4.54 \%$ & $0.64[0.42,0.96]$ \\
\hline Merenstein 2009 & $13 / 61$ & $15 / 64$ & & & - & & $3.72 \%$ & $0.91[0.47,1.75]$ \\
\hline Olek 2017 & $9 / 223$ & $10 / 224$ & & & - & & $2.99 \%$ & $0.9[0.37,2.18]$ \\
\hline Ruszczynski 2008 & $9 / 120$ & $20 / 120$ & & & & & $3.41 \%$ & $0.45[0.21,0.95]$ \\
\hline Saneeyan 2011 & $3 / 50$ & $13 / 50$ & & & & & $2.19 \%$ & $0.23[0.07,0.76]$ \\
\hline Sykora 2005 & $5 / 39$ & $6 / 47$ & & & & & $2.38 \%$ & $1[0.33,3.04]$ \\
\hline Szajewska 2009 & $8 / 44$ & $8 / 39$ & & & - & & $2.99 \%$ & $0.89[0.37,2.14]$ \\
\hline Szymanski 2008 & $1 / 40$ & $2 / 38$ & & & & & $0.81 \%$ & $0.48[0.04,5.03]$ \\
\hline Tankanow 1990 & $19 / 30$ & $17 / 30$ & & & - & & $4.54 \%$ & $1.12[0.74,1.69]$ \\
\hline Vanderhoof 1999 & $11 / 99$ & $27 / 103$ & & 1 & & & $3.75 \%$ & $0.42[0.22,0.81]$ \\
\hline Subtotal $(95 \% \mathrm{Cl})$ & 1283 & 1288 & & & & & $53.55 \%$ & $0.71[0.54,0.92]$ \\
\hline \multicolumn{9}{|c|}{ Total events: 164 (Treatment), 236 (Control) } \\
\hline \multicolumn{9}{|c|}{ Heterogeneity: $\operatorname{Tau}^{2}=0.14 ; \mathrm{Chi}^{2}=34.46, \mathrm{df}=18(\mathrm{P}=0.01) ; \mathrm{I}^{2}=47.77 \%$} \\
\hline \multicolumn{9}{|c|}{ Test for overall effect: $Z=2.56(P=0.01)$} \\
\hline \multicolumn{9}{|c|}{ 1.14.3 No treatment control } \\
\hline Conway 2007 & $8 / 74$ & $2 / 32$ & & & + & & $1.64 \%$ & $1.73[0.39,7.7]$ \\
\hline Destura unpublished & $3 / 162$ & $7 / 161$ & & & - & & $1.9 \%$ & $0.43[0.11,1.62]$ \\
\hline Dharani 2017 & $0 / 50$ & $3 / 50$ & & & & & $0.55 \%$ & $0.14[0.01,2.7]$ \\
\hline Erdeve 2004 & $63 / 326$ & $63 / 327$ & & & $t$ & & $4.84 \%$ & $1[0.73,1.37]$ \\
\hline Jindal 2017 & $16 / 300$ & $72 / 300$ & & $\longrightarrow$ & & & $4.19 \%$ & $0.22[0.13,0.37]$ \\
\hline Peng 2014 & $11 / 56$ & $30 / 56$ & & 千 & & & $3.96 \%$ & $0.37[0.2,0.66]$ \\
\hline Shan 2013 & $28 / 167$ & $46 / 166$ & & + & & & $4.53 \%$ & $0.61[0.4,0.92]$ \\
\hline Wan 2017 & $5 / 213$ & $32 / 195$ & & 1 & & & $2.87 \%$ & $0.14[0.06,0.36]$ \\
\hline Zakordonets 2016 & $0 / 20$ & $6 / 20$ & & & & & $0.59 \%$ & $0.08[0,1.28]$ \\
\hline Zhang 2015 & $14 / 105$ & $28 / 100$ & & 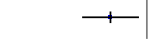 & & & $3.97 \%$ & $0.48[0.27,0.85]$ \\
\hline Zhao 2014 & $27 / 120$ & $47 / 120$ & & $\rightarrow$ & & & $4.58 \%$ & $0.57[0.39,0.86]$ \\
\hline Zheng 2012 & $17 / 197$ & $31 / 183$ & & 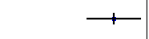 & & & $4.06 \%$ & $0.51[0.29,0.89]$ \\
\hline Subtotal $(95 \% \mathrm{Cl})$ & 1790 & 1710 & & & & & $37.69 \%$ & $0.46[0.31,0.66]$ \\
\hline \multicolumn{9}{|c|}{ Total events: 192 (Treatment), 367 (Control) } \\
\hline \multicolumn{9}{|c|}{ Heterogeneity: $\mathrm{Tau}^{2}=0.26 ; \mathrm{Chi}^{2}=42.56, \mathrm{df}=11(\mathrm{P}<0.0001) ; \mathrm{I}^{2}=74.15 \%$} \\
\hline \multicolumn{9}{|c|}{ Test for overall effect: $Z=4.11(P<0.0001)$} \\
\hline Total $(95 \% \mathrm{Cl})$ & 3551 & 3468 & & $\diamond$ & & & $100 \%$ & $0.61[0.49,0.77]$ \\
\hline \multicolumn{9}{|c|}{ Total events: 436 (Treatment), 664 (Control) } \\
\hline \multicolumn{9}{|c|}{ Heterogeneity: $\operatorname{Tau}^{2}=0.26 ; \mathrm{Chi}^{2}=107.22, \mathrm{df}=32(\mathrm{P}<0.0001) ; \mathrm{I}^{2}=70.15 \%$} \\
\hline & & rs treatment & 0.01 & 0.1 & 10 & 100 & Favours control & \\
\hline
\end{tabular}




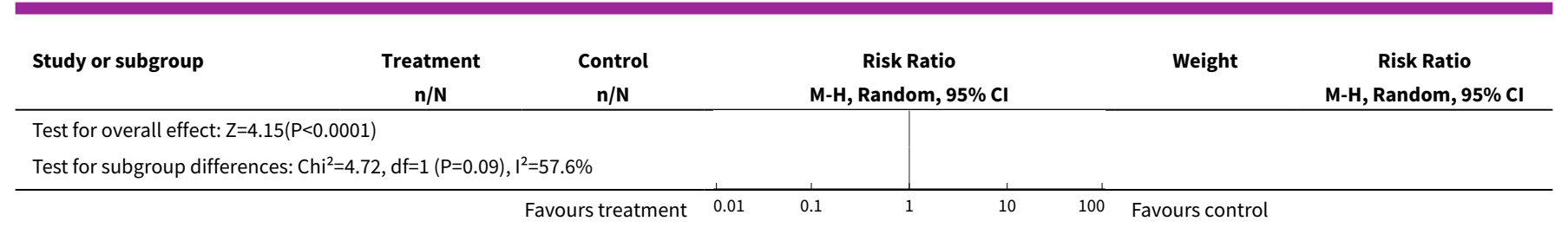

\section{Analysis 1.15. Comparison 1 Probiotics versus control, Outcome 15 Adverse events: Complete case.}

\begin{tabular}{|c|c|c|c|c|c|}
\hline Study or subgroup & $\begin{array}{c}\text { Treatment } \\
\mathrm{n} / \mathrm{N}\end{array}$ & $\begin{array}{c}\text { Control } \\
n / N\end{array}$ & $\begin{array}{c}\text { Risk Difference } \\
\text { M-H, Random, } 95 \% \mathrm{CI}\end{array}$ & Weight & $\begin{array}{c}\text { Risk Difference } \\
\text { M-H, Random, } 95 \% \mathrm{Cl}\end{array}$ \\
\hline Conway 2007 & $0 / 74$ & $0 / 32$ & + & $3.91 \%$ & $0[-0.05,0.05]$ \\
\hline Correa 2005 & $5 / 80$ & $0 / 77$ & 1 & $2.84 \%$ & $0.06[0,0.12]$ \\
\hline Destura unpublished & $0 / 162$ & $0 / 161$ & * & $9.46 \%$ & $0[-0.01,0.01]$ \\
\hline Dharani 2017 & $5 / 50$ & $9 / 50$ & $\because-$ & $0.66 \%$ & $-0.08[-0.22,0.06]$ \\
\hline Fox 2015 & $3 / 34$ & $11 / 36$ & * & $0.39 \%$ & $-0.22[-0.4,-0.04]$ \\
\hline Jindal 2017 & $0 / 300$ & $0 / 300$ & & $10.24 \%$ & $0[-0.01,0.01]$ \\
\hline Jirapinyo 2002 & $0 / 8$ & $0 / 10$ & 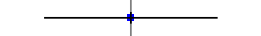 & $0.33 \%$ & $0[-0.19,0.19]$ \\
\hline King 2010 & $0 / 8$ & $0 / 7$ & & $0.25 \%$ & $0[-0.22,0.22]$ \\
\hline Kodadad 2013 & $5 / 33$ & $13 / 33$ & - & $0.29 \%$ & $-0.24[-0.45,-0.04]$ \\
\hline Kolodziej 2018 & $3 / 123$ & $7 / 124$ & + & $3.56 \%$ & $-0.03[-0.08,0.02]$ \\
\hline Kotowska 2005 & $0 / 119$ & $0 / 127$ & + & $8.79 \%$ & $0[-0.02,0.02]$ \\
\hline Merenstein 2009 & $1 / 57$ & $1 / 60$ & + & $3.75 \%$ & $0[-0.05,0.05]$ \\
\hline Olek 2017 & $39 / 218$ & $60 / 220$ & 1 & $1.77 \%$ & $-0.09[-0.17,-0.02]$ \\
\hline Peng 2014 & $0 / 56$ & $3 / 56$ & - & $2.26 \%$ & $-0.05[-0.12,0.01]$ \\
\hline Ruszczynski 2008 & $0 / 120$ & $0 / 120$ & $*$ & $8.72 \%$ & $0[-0.02,0.02]$ \\
\hline Shan 2013 & $0 / 139$ & $0 / 144$ & $*$ & $9.17 \%$ & $0[-0.01,0.01]$ \\
\hline Sykora 2005 & $4 / 39$ & $4 / 47$ & . & $0.77 \%$ & $0.02[-0.11,0.14]$ \\
\hline Szajewska 2009 & $18 / 35$ & $13 / 32$ & 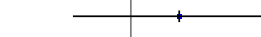 & $0.22 \%$ & $0.11[-0.13,0.35]$ \\
\hline Szymanski 2008 & $0 / 40$ & $0 / 38$ & $t$ & $3.58 \%$ & $0[-0.05,0.05]$ \\
\hline Tankanow 1990 & $3 / 15$ & $0 / 23$ & & $0.28 \%$ & $0.2[-0.01,0.41]$ \\
\hline Vanderhoof 1999 & $0 / 93$ & $0 / 95$ & + & $7.85 \%$ & $0[-0.02,0.02]$ \\
\hline Wan 2017 & $0 / 213$ & $0 / 195$ & 申 & $9.85 \%$ & $0[-0.01,0.01]$ \\
\hline Zakordonets 2016 & $0 / 20$ & $0 / 20$ & 1 & $1.32 \%$ & $0[-0.09,0.09]$ \\
\hline Zheng 2012 & $0 / 193$ & $0 / 179$ & $*$ & $9.71 \%$ & $0[-0.01,0.01]$ \\
\hline Total $(95 \% \mathrm{Cl})$ & 2229 & 2186 & 1 & $100 \%$ & $-0[-0.01,0.01]$ \\
\hline \multicolumn{6}{|c|}{ Total events: 86 (Treatment), 121 (Control) } \\
\hline \multicolumn{6}{|c|}{ Heterogeneity: $\mathrm{Tau}^{2}=0 ; \mathrm{Chi}^{2}=91.18, \mathrm{df}=23(\mathrm{P}<0.0001) ; \mathrm{I}^{2}=74.78 \%$} \\
\hline \multicolumn{6}{|c|}{ Test for overall effect: $Z=0.58(P=0.56)$} \\
\hline
\end{tabular}

\section{Analysis 1.16. Comparison 1 Probiotics versus control, Outcome 16 Adverse events: Same event rate assumptions analysis.}

\begin{tabular}{|c|c|c|c|c|c|}
\hline Study or subgroup & $\begin{array}{c}\text { Treatment } \\
\mathrm{n} / \mathrm{N} \\
\end{array}$ & $\begin{array}{c}\text { Control } \\
\mathrm{n} / \mathrm{N}\end{array}$ & $\begin{array}{c}\text { Risk Difference } \\
\text { M-H, Random, 95\% Cl }\end{array}$ & Weight & $\begin{array}{c}\text { Risk Difference } \\
\text { M-H, Random, } 95 \% \mathrm{CI}\end{array}$ \\
\hline Conway 2007 & $0 / 74$ & $0 / 32$ & - & $3.86 \%$ & $0[-0.05,0.05]$ \\
\hline Correa 2005 & $5 / 87$ & $0 / 82$ & & $3.14 \%$ & $0.06[0,0.11]$ \\
\hline Destura unpublished & $0 / 162$ & $0 / 161$ & $\longrightarrow$ & $9.26 \%$ & $0[-0.01,0.01]$ \\
\hline
\end{tabular}




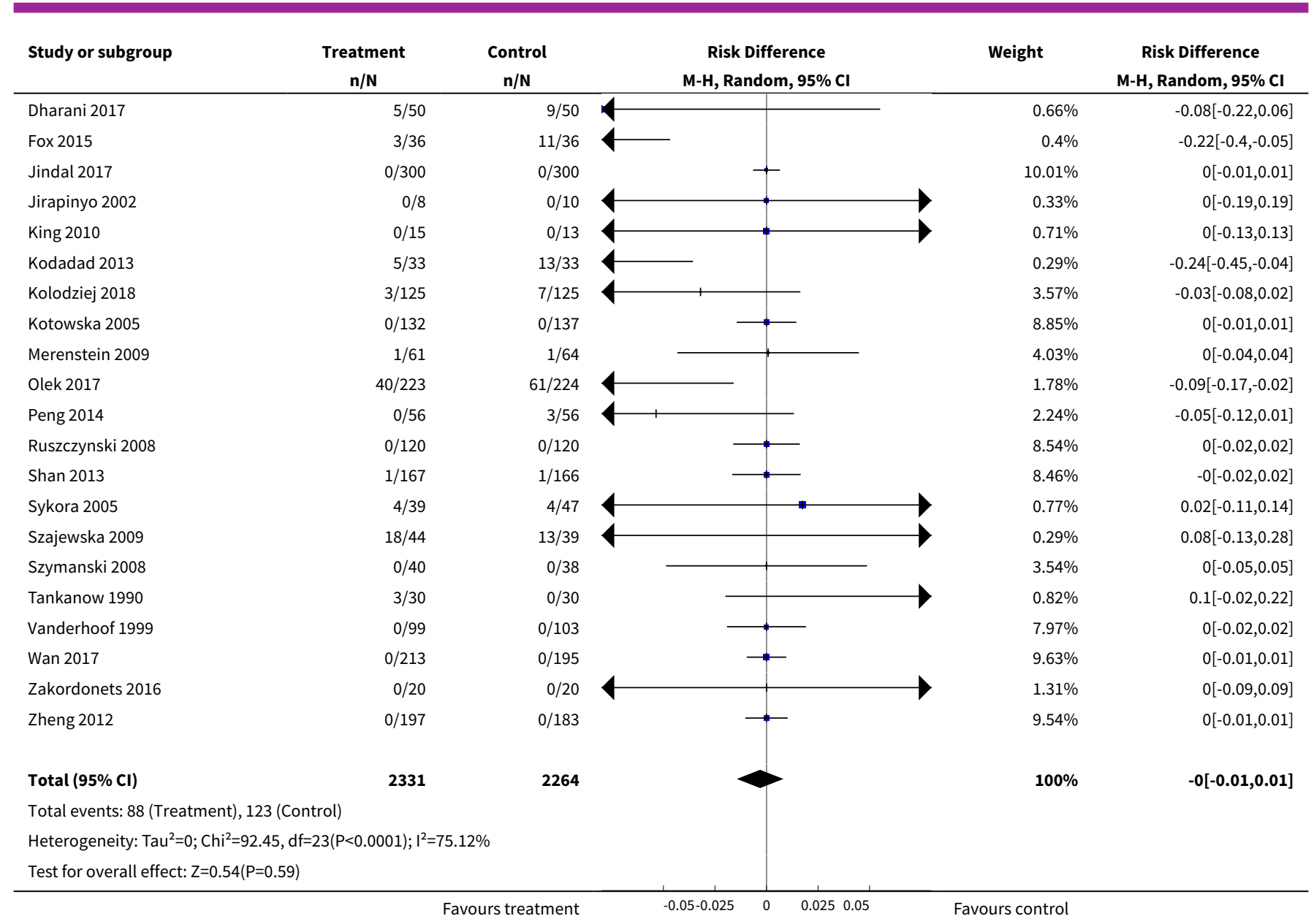

Analysis 1.17. Comparison 1 Probiotics versus control, Outcome 17 Adverse events: Risk of bias.

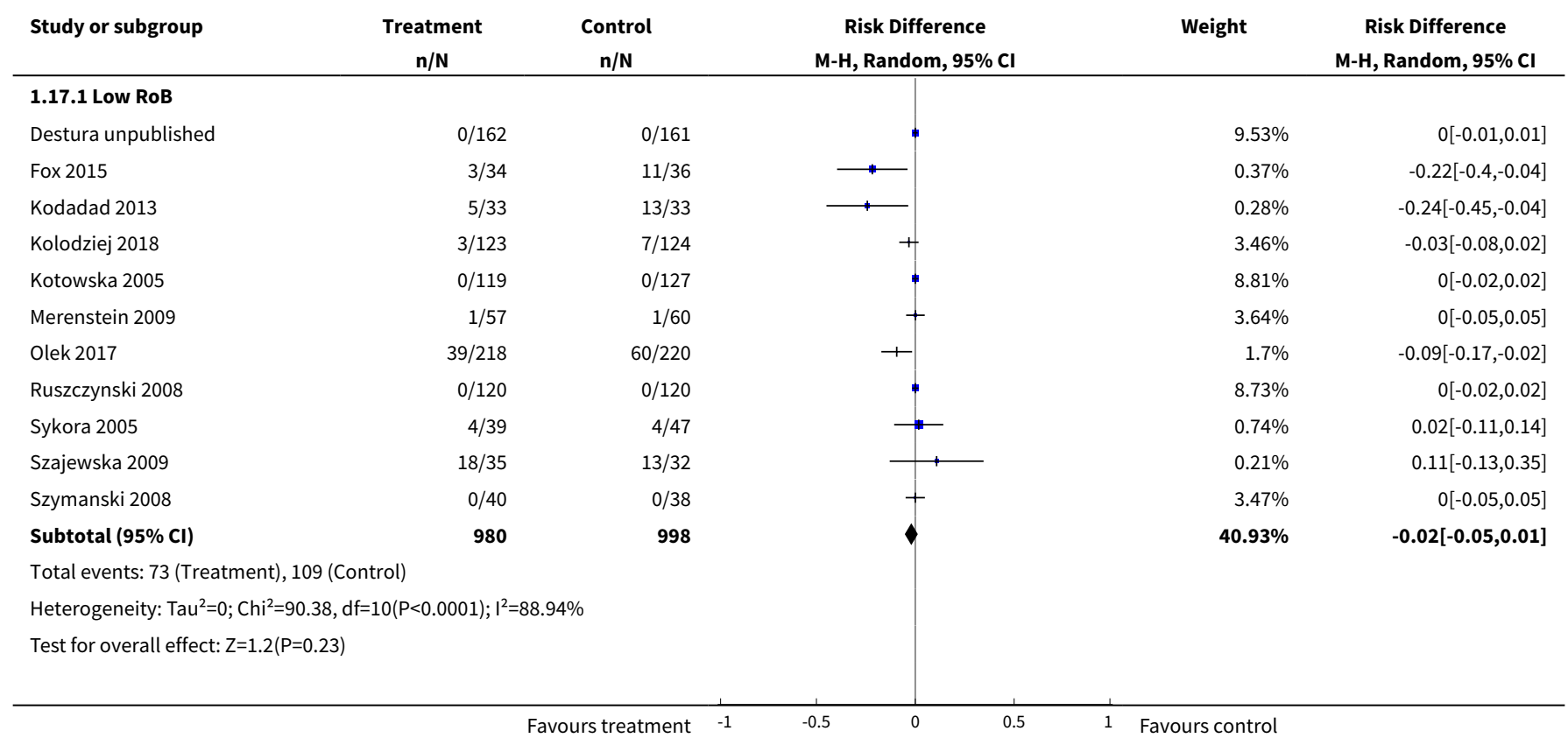




\begin{tabular}{|c|c|c|c|c|c|}
\hline Study or subgroup & $\begin{array}{c}\text { Treatment } \\
\mathrm{n} / \mathrm{N}\end{array}$ & $\begin{array}{c}\text { Control } \\
n / N\end{array}$ & $\begin{array}{c}\text { Risk Difference } \\
\text { M-H, Random, } 95 \% \mathrm{CI}\end{array}$ & Weight & $\begin{array}{c}\text { Risk Difference } \\
\text { M-H, Random, } 95 \% \mathrm{CI}\end{array}$ \\
\hline \multicolumn{6}{|l|}{ 1.17.2 High/Unclear } \\
\hline Conway 2007 & $0 / 74$ & $0 / 32$ & + & $3.8 \%$ & $0[-0.05,0.05]$ \\
\hline Correa 2005 & $5 / 80$ & $0 / 77$ & + & $2.74 \%$ & $0.06[0,0.12]$ \\
\hline Dharani 2017 & $5 / 50$ & $9 / 50$ & $\rightarrow$ & $0.63 \%$ & $-0.08[-0.22,0.06]$ \\
\hline Jindal 2017 & $0 / 300$ & $0 / 300$ & 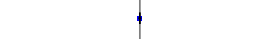 & $10.36 \%$ & $0[-0.01,0.01]$ \\
\hline Jirapinyo 2002 & $0 / 8$ & $0 / 10$ & $\longrightarrow$ & $0.32 \%$ & $0[-0.19,0.19]$ \\
\hline King 2010 & $0 / 8$ & $0 / 7$ & 1 & $0.24 \%$ & $0[-0.22,0.22]$ \\
\hline Peng 2014 & $0 / 56$ & $2 / 56$ & + & $2.68 \%$ & $-0.04[-0.09,0.02]$ \\
\hline Shan 2013 & $0 / 139$ & $0 / 144$ & $\phi$ & $9.21 \%$ & $0[-0.01,0.01]$ \\
\hline Tankanow 1990 & $3 / 15$ & $0 / 23$ & $\longrightarrow$ & $0.27 \%$ & $0.2[-0.01,0.41]$ \\
\hline Vanderhoof 1999 & $0 / 93$ & $0 / 95$ & $*$ & $7.82 \%$ & $0[-0.02,0.02]$ \\
\hline Wan 2017 & $0 / 213$ & $0 / 195$ & \% & $9.94 \%$ & $0[-0.01,0.01]$ \\
\hline Zakordonets 2016 & $0 / 20$ & $0 / 20$ & + & $1.26 \%$ & $0[-0.09,0.09]$ \\
\hline Zheng 2012 & $0 / 193$ & $0 / 179$ & 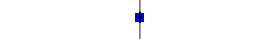 & $9.8 \%$ & $0[-0.01,0.01]$ \\
\hline Subtotal $(95 \% \mathrm{Cl})$ & 1249 & 1188 & & $59.07 \%$ & $0[-0,0]$ \\
\hline \multicolumn{6}{|c|}{ Total events: 13 (Treatment), 11 (Control) } \\
\hline \multicolumn{6}{|c|}{ Heterogeneity: $\mathrm{Tau}^{2}=0 ; \mathrm{Chi}^{2}=11.53, \mathrm{df}=12(\mathrm{P}=0.48) ; \mathrm{I}^{2}=0 \%$} \\
\hline \multicolumn{6}{|c|}{ Test for overall effect: $Z=0.07(P=0.94)$} \\
\hline Total $(95 \% \mathrm{Cl})$ & 2229 & 2186 & 1 & $100 \%$ & $-0[-0.01,0.01]$ \\
\hline \multicolumn{6}{|c|}{ Total events: 86 (Treatment), 120 (Control) } \\
\hline \multicolumn{6}{|c|}{ Heterogeneity: $\mathrm{Tau}^{2}=0 ; \mathrm{Chi}^{2}=86.81, \mathrm{df}=23(\mathrm{P}<0.0001) ; \mathrm{I}^{2}=73.5 \%$} \\
\hline \multicolumn{6}{|c|}{ Test for overall effect: $\mathrm{Z}=0.53(\mathrm{P}=0.59)$} \\
\hline \multicolumn{6}{|c|}{ Test for subgroup differences: $\mathrm{Chi}^{2}=1.43, \mathrm{df}=1(\mathrm{P}=0.23), \mathrm{I}^{2}=29.97 \%$} \\
\hline
\end{tabular}

\section{Analysis 1.18. Comparison 1 Probiotics versus control, Outcome 18 Mean duration of diarrhea: Complete case.}

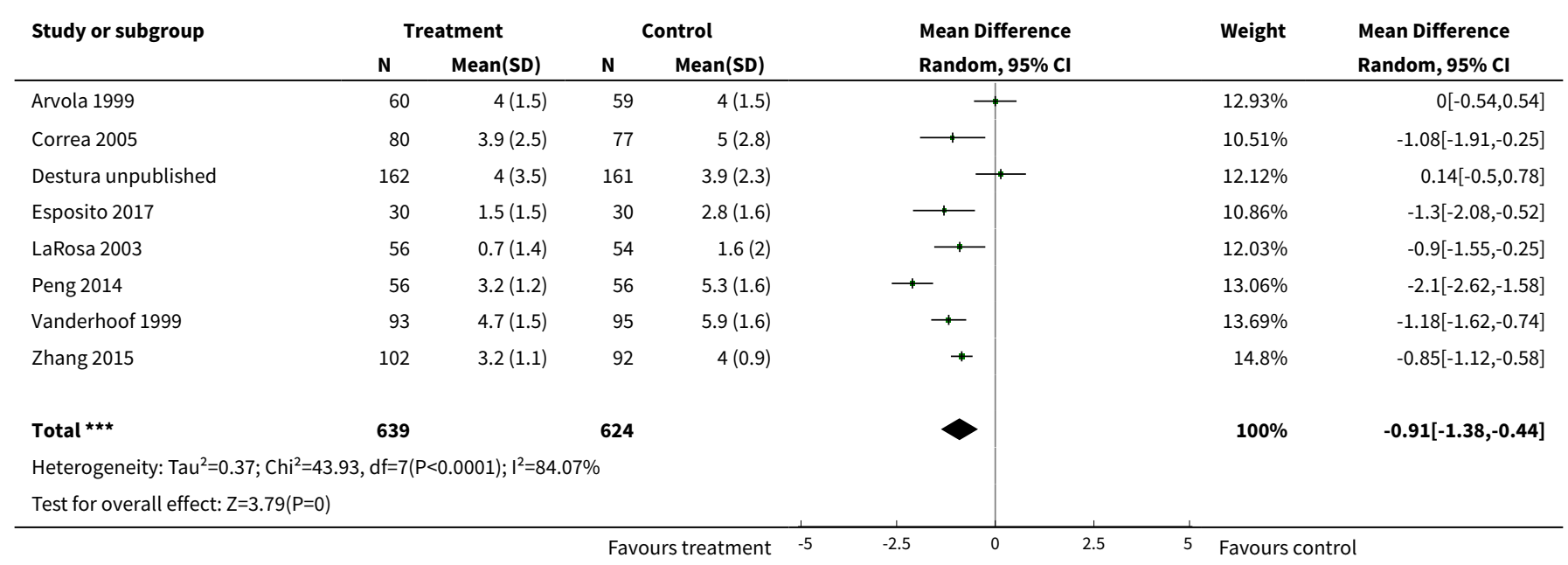




\section{A P P E D I CES}

\section{Appendix 1. Search strategies \\ MEDLINE}

1 exp probiotics/or probiotic ${ }^{\star} . \mathrm{mp}$.

2 exp lactobacillus/ or (lactobacill* or "I acidophilus" or "I casei").mp.

3 exp bifidobacterium/ or (bifidobacter* or "b infantis" or "b bifidum" or "b longum").mp.

4 exp saccharomyces/ or (saccaromyce* or "s boulardii").mp.

5 clostridium butyricum/ or clostridium difficile/ or (clostridium butyricum or clostridium difficile).mp.

6 streptococcus thermophilus/ or streptococcus thermophilus.mp.

7 enterococcus faecium/ or enterococcus faecium.mp.

8 or/1-7

9 exp anti-bacterial agents/

10 (antibiotic $^{\star}$ or anti biotic ${ }^{\star}$ or antimicrobial ${ }^{\star}$ or anti microbial ${ }^{\star}$ or antimycobial ${ }^{\star}$ or anti mycobial ${ }^{\star}$ or antimycobacteri* or anti mycobacteri $^{\star}$ or antibacteri* or anti bacteri ${ }^{\star}$ or bacteriocid ${ }^{\star}$ or antiinfective ${ }^{\star}$ or anti infective $\left.{ }^{\star}\right) . m p$.

11 or/9-10

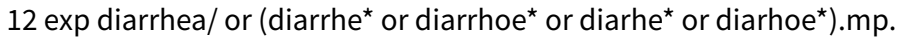

13 exp dysentery/ or dysenter ${ }^{\star} . \mathrm{mp}$.

14 gastroenteritis/ or (gastroenteritis or gastro enteritis).mp.

15 or/12-14

168 and 11 and 15

17 pediatrics/

18 (infan* or newborn* or new-born* or perinat* or neonat* or baby or baby* or babies or toddler* or minors or minors* or boy or boys or boyfriend or boyhood or girl ${ }^{\star}$ or kid or kids or child or child* or children* or schoolchild* or schoolchild or adolescen* or juvenil ${ }^{\star}$ or youth $^{\star}$ or teen ${ }^{\star}$ or underage or pubescen $^{\star}$ or pediatric ${ }^{\star}$ or paediatric ${ }^{\star}$ or peadiatric ${ }^{\star}$ or prematur ${ }^{\star}$ or preterm ${ }^{\star}$.mp.

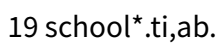

20 or/17-19

2116 and 20

22 randomized controlled trial.pt.

23 controlled clinical trial.pt.

24 randomized.ab.

25 placebo.ab.

26 drug therapy.fs.

27 randomly.ab.

28 trial.ab.

29 groups.ab.

30 or $/ 21-29$ 
31 exp animals/ not humans.sh.

$3230 \operatorname{not} 31$

3321 and 32

\section{Embase}

1 'probiotic agent'/exp OR probiotic*

2 'lactobacillus'/exp OR lactobacill* OR 'I acidophilus' OR 'I casei'

3 'bifidobacterium'/exp OR bifidobacter* OR 'b infantis' OR 'b bifidum' OR 'b longum'

4 'saccharomyces'/exp OR saccaromyce* OR 's boulardii'

5 'clostridium butyricum'/exp OR 'peptoclostridium difficile'/exp OR 'clostridium butyricum' OR 'clostridium difficile' OR 'peptoclostridium difficile'

6 'streptococcus thermophilus'/exp OR 'streptococcus thermophilus'

7 'enterococcus faecium'/exp OR 'enterococcus faecium'

\section{$8 \# 1$ OR \#2 OR \#3 OR \#4 OR \#5 OR \#6 OR \#7}

9 'antiinfective agent'/exp

10 antibiotic $^{\star}$ OR 'anti biotic* OR antimicrobial ${ }^{\star}$ OR 'anti microbial ${ }^{\star \prime}$ OR antimycobial ${ }^{\star}$ OR 'anti mycobial ${ }^{\star \prime}$ OR antimycobacteri" OR 'anti mycobacteri ${ }^{\star \prime}$ OR antibacteri ${ }^{\star}$ OR 'anti bacteri ${ }^{\star \prime}$ OR bacteriocid ${ }^{\star}$ OR antiinfective* OR 'anti infective ${ }^{\star \prime}$

\section{1 \#9 OR \#10}

12 diarrhea'/exp OR diarrhe* OR diarrhoe* OR diarhe* OR diarhoe*

13 'dysentery'/exp OR dysenter*

14 'gastroenteritis'/exp OR gastroenteritis OR 'gastro enteritis'

\section{5 \#12 OR \#13 OR \#14}

16 \#8 AND \#11 AND \#15

17 'pediatrics'/de

18 infan* OR newborn* OR 'new-born*' OR perinat* OR neonat* OR baby OR baby* OR babies OR toddler* OR minors OR minors* OR boy OR boys OR boyfriend OR boyhood OR girl ${ }^{\star}$ OR kid OR kids OR child OR child* OR children* OR schoolchild* OR schoolchild OR adolescen ${ }^{\star}$ OR juvenil ${ }^{\star}$ OR youth ${ }^{\star}$ OR teen ${ }^{\star}$ OR underage ${ }^{\star}$ OR pubescen ${ }^{\star}$ OR pediatric ${ }^{\star}$ OR paediatric ${ }^{\star}$ OR peadiatric ${ }^{\star}$ OR prematur ${ }^{\star}$ OR preterm $^{\star}$

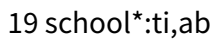

\section{0 \#17 OR \#18 OR \#19}

\section{1 \#16 AND \#20}

22 random*

23 'clinical trial ${ }^{\star \prime}$

24 'treatment outcome'/exp

\section{$25 \# 22$ OR \#23 OR \#24}

26 'human'/de

27 'nonhuman'/de

28 'animal'/exp

29 'animal experiment'/de

Probiotics for the prevention of pediatric antibiotic-associated diarrhea (Review) 
$30 \# 27$ OR \#28 OR \#29

\section{1 \#30 NOT \#26}

32 \#25 NOT \#31

33 \#21 AND \#32

\section{CENTRAL}

1 probiotic*

2 lactobacill* or "l acidophilus" or "l casei"

3 bifidobacter* or "b infantis" or "b bifidum" or "b longum"

4 saccaromyce* or "s boulardii"

5 clostridium butyricum or clostridium difficile

6 streptococcus thermophilus

7 enterococcus faecium

$8 \# 1$ or \#2 or \#3 or \#4 or \#5 or \#6 or \#7

9 antibiotic ${ }^{\star}$ or anti biotic ${ }^{\star}$ or antimicrobial ${ }^{\star}$ or anti microbial ${ }^{\star}$ or antimycobial ${ }^{\star}$ or anti mycobial ${ }^{\star}$ or antimycobacteri ${ }^{\star}$ or anti mycobacteri ${ }^{\star}$ or antibacteri ${ }^{\star}$ or anti bacteri ${ }^{\star}$ or bacteriocid ${ }^{\star}$ or antiinfective ${ }^{\star}$ or anti infective ${ }^{\star}$

10 diarrhe* $^{\star}$ or diarrhoe ${ }^{\star}$ or diarhe* or diarhoe*

11 dysenter $^{*}$

12 gastroenteritis or gastro enteritis

$13 \# 10$ or \#11 or \#12

$14 \# 8$ and \#9 and \#13

15 infan* or newborn* or 'new-born*' or perinat* or neonat* or baby or baby* or babies or toddler ${ }^{\star}$ or minors or minors ${ }^{\star}$ or boy or boys or boyfriend or boyhood or girl* or kid or kids or child or child* or children* or schoolchild* or schoolchild or adolescen* or juvenil* or youth* or teen ${ }^{\star}$ or underage ${ }^{\star}$ or pubescen ${ }^{\star}$ or pediatric ${ }^{\star}$ or paediatric ${ }^{\star}$ or peadiatric ${ }^{\star}$ or prematur ${ }^{\star}$ or preterm ${ }^{\star}$

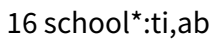

$17 \# 15$ or \#16

$18 \# 14$ and \#17

\section{CINAHL with Full Text}

1 (MH "Probiotics") OR probiotic*

2 (MH "Lactobacillus+") OR lactobacill* OR "I acidophilus" OR "I casei"

3 (MH "Bifidobacterium") OR bifidobacter* OR "b infantis" OR "b bifidum" OR "b longum"

4 (MH "Saccharomyces") OR saccaromyce* OR "s boulardii"

5 (MH "Clostridium Difficile") OR clostridium butyricum OR clostridium difficile

6 streptococcus thermophilus

7 (MH "Enterococcus Faecium") OR enterococcus faecium

\section{S1 OR S2 OR S3 OR S4 OR S5 OR S6 OR S7}

9 (MH "Antiinfective Agents+") 
10 antibiotic $^{\star}$ OR anti biotic ${ }^{\star}$ OR antimicrobial ${ }^{\star}$ OR anti microbial ${ }^{\star}$ OR antimycobial ${ }^{\star}$ OR anti mycobial ${ }^{\star}$ OR antimycobacteri $^{\star}$ OR anti mycobacteri ${ }^{\star}$ OR antibacteri ${ }^{\star}$ OR anti bacteri ${ }^{\star}$ OR bacteriocid ${ }^{\star}$ OR antiinfective ${ }^{\star}$ OR anti infective ${ }^{\star}$

11 S9 OR S 10

12 (MH "Diarrhea") OR diarrhe* OR diarrhoe* OR diarhe* OR diarhoe*

13 (MH "Dysentery+") OR dysenter*

14 (MH "Gastroenteritis") OR gastroenteritis OR gastro enteritis

15 S12 OR S13 OR S14

16 S8 AND S11 AND S15

17 (MH "Pediatrics")

18 infan* OR newborn* OR new-born* OR perinat* OR neonat* OR baby OR baby* OR babies OR toddler* OR minors OR minors* OR boy OR boys OR boyfriend OR boyhood OR girl* OR kid OR kids OR child OR child* OR children* OR schoolchild* OR schoolchild OR adolescen* OR juvenil* OR youth* OR teen ${ }^{\star}$ OR underage* OR pubescen* OR pediatric ${ }^{\star}$ OR paediatric* OR peadiatric* OR prematur ${ }^{\star}$ OR preterm ${ }^{\star}$

$19 \mathrm{TI}_{\text {school}}^{*}$ OR AB school*

20 S17 OR S18 OR S19

21 S16 AND S20

22 (MH "Treatment Outcomes+")

23 experimental studies

24 TX random*

25 S22 OR S23 OR S24

26 S21 AND S25

\section{Web of Science Core Collection}

$1 \mathrm{TS}=$ probiotic $^{*}$

2 TS=(lactobacill* OR "I acidophilus" OR "I casei")

3 TS=(bifidobacter* OR "b infantis" OR "b bifidum" OR "b longum")

$4 \mathrm{TS}=\left(\right.$ saccaromyce ${ }^{\star}$ OR "s boulardii")

5 TS=("clostridium butyricum" OR "clostridium difficile")

6 TS="streptococcus thermophilus"

7 TS="enterococcus faecium"

8 \#7 OR \#6 OR \#5 OR \#4 OR \#3 OR \#2 OR \#1

9 TS=(antibiotic* OR "anti biotic ${ }^{\star} "$ OR antimicrobial ${ }^{\star}$ OR "anti microbial ${ }^{\star} "$ OR antimycobial ${ }^{\star}$ OR "anti mycobial*" OR antimycobacteri ${ }^{\star}$ OR "anti mycobacteri*" OR antibacteri ${ }^{\star}$ OR "anti bacteri*" OR bacteriocid ${ }^{\star}$ OR antiinfective* OR "anti infective*")

10 TS=(diarrhe ${ }^{\star}$ OR diarrhoe $^{\star}$ OR diarhe $^{\star}$ OR diarhoe $\left.^{\star}\right)$

11 TS=dysenter ${ }^{*}$

12 TS=(gastroenteritis OR "gastro enteritis")

13 \#12 OR \#11 OR \#10

14 \#13 AND \#9 AND \#8 
15 TS=(infan^ OR newborn* OR "new-born*" OR perinat* OR neonat* OR baby OR baby* OR babies OR toddler* OR minors OR minors* OR boy OR boys OR boyfriend OR boyhood OR girl* OR kid OR kids OR child OR child* OR children* OR school* OR adolescen* OR juvenil* OR youth* OR teen ${ }^{\star}$ OR underage ${ }^{\star}$ OR pubescen ${ }^{\star}$ OR pediatric ${ }^{\star}$ OR paediatric ${ }^{\star}$ OR peadiatric ${ }^{\star}$ OR prematur ${ }^{\star}$ OR preterm $^{\star}$ )

\section{6 \#15 AND \#14}

17 TS=("clinical trial*" OR "research design" OR "comparative stud*" OR "evaluation stud*" OR "controlled trial*" OR "follow-up stud*" OR "prospective stud*" OR random* OR placebo* OR "single blind*" OR "double blind*")

18 TS=animal ${ }^{\star}$ NOT TS=human*

19 \#17 NOT \#18

20 \#19 AND \#16

Appendix 2. Assessing the credibility of a subgroup analysis results: 5 questions*

Table 1. Are the subgroup results significant?

\begin{tabular}{|c|c|c|c|}
\hline Analysis number and name of subgroup & Number of studies & Pvalue & $\begin{array}{l}\mathrm{Y} / \mathrm{N} \text { (Is it signifi- } \\
\text { cant?) }\end{array}$ \\
\hline 1.2 IOD: Inpatient vs outpatient & 21 & 0.12 & $\mathrm{~N}$ \\
\hline 1.3 IOD: Diagnosis & 27 & 0.91 & $\mathrm{~N}$ \\
\hline 1.4 IOD: Probiotic species ${ }^{\star \star}$ & $15^{1}$ & 0.94 & $\mathrm{~N}$ \\
\hline 1.5 IOD: Single strain vs multi strain & 33 & 0.34 & $\mathrm{~N}$ \\
\hline 1.6 IOD: Probiotic dose & 32 & 0.01 & $\mathrm{Y}$ \\
\hline 1.7 IOD: Definition of diarrhea** & $22^{2}$ & 0.30 & $\mathrm{~N}$ \\
\hline 1.8 IOD: Strictness of definition & 25 & 0.95 & $\mathrm{~N}$ \\
\hline 1.9 IOD: Industry sponsorship & 17 & 0.52 & $\mathrm{~N}$ \\
\hline 1.10 IOD: Risk of bias & 33 & 0.30 & $\mathrm{~N}$ \\
\hline 1.11 IOD: Age & 32 & 0.18 & $\mathrm{~N}$ \\
\hline
\end{tabular}

Footnote:

* Sun X, loannidis JP, Agoritsas T, Alba AC, Guyatt G. How to use a subgroup analysis: users' guide to the medical literature. JAMA. 2014 Jan 22-29;311(4):405-11.

** We added an extra subgroup criterion based on number of studies for subgroups of interest; to do so we deleted those subgroups which included less than 5 studies (e.g. species and strain often have subgroup estimates for 1 to 4 studies. Otherwise, observed subgroup effects may underpowered and may be due to between study variability (age, socioeconomic status) that correlate with the outcome of interest.

1 Studies included the species which named "Lactobacillus rhamnosus (strain: GG and E/N, Oxy, Pen )" and "Saccharomyces boulardii" and there are 6 and 9 studies, respectively.

2 Studies include 2 definitions of AAD: " 3 or more loose/watery/liquid stools per day for at least 2 consecutive days" and " 3 or more watery/ liquid stools per 24 hours" with 13 and 9 studies, respectively, falling into these categories. 
Table 2. the credibility of the subgroup analysis of "Probiotic dose"

\begin{tabular}{|c|c|}
\hline Items of subgroup & Answer \\
\hline $\begin{array}{l}\text { 1. Based P-value Above, Can Chance Explain the Subgroup Dif- } \\
\text { ference? }\end{array}$ & Probably No $(P=0.008)$ \\
\hline 2. Is the Subgroup Difference Consistent Across Studies? & $\begin{array}{l}\text { Probably Yes. High does studies mostly tend to have larger treat- } \\
\text { ment effects. Results not driven by large studies }\end{array}$ \\
\hline $\begin{array}{l}\text { 3. Was the Subgroup Difference One of a Small Number of a Pri- } \\
\text { ori Hypotheses in Which the Direction Was Accurately Prespeci- } \\
\text { fied? }\end{array}$ & Probably Yes. We tested 9 a priori subgroups \\
\hline $\begin{array}{l}\text { 4. Is There a Strong Preexisting Biological Rationale Supporting } \\
\text { the Apparent Subgroup Effect? }\end{array}$ & $\begin{array}{l}\text { Probably Yes. Previous studies have demonstrated a dose re- } \\
\text { sponse (see citations in review). However, dose may be confound- } \\
\text { ed by studies that use multiple strains which may increase effec- } \\
\text { tiveness }\end{array}$ \\
\hline $\begin{array}{l}\text { 5. Is the Subgroup Difference Suggested by Comparisons within } \\
\text { Rather than Between Studies? }\end{array}$ & $\begin{array}{l}\text { No. The observed dose-response difference among all } 33 \text { studies } \\
\text { is based on between study data. }\end{array}$ \\
\hline
\end{tabular}

* Given this, the dose response is unlikely attributable to within-study rather than between study differences.

\section{WHAT'S NEW}

\begin{tabular}{lll}
\hline Date & Event & Description \\
\hline 13 May 2019 & Amended & Correction of minor error in plain language summary \\
\hline
\end{tabular}

\section{H I S T ORY}

Protocol first published: Issue 3, 2004

Review first published: Issue 2, 2007

\begin{tabular}{lll}
\hline Date & Event & Description \\
\hline 28 May 2018 & $\begin{array}{l}\text { New citation required but conclusions } \\
\text { have not changed }\end{array}$ & Updated review with new authors \\
\hline 28 May 2018 & New search has been performed & New search, new studies added \\
\hline
\end{tabular}

\section{CONTRIBUTIONS OF AUTHORS}

This version of the review:

Qin Guo: Screening, inclusion/exclusion, data extraction, quality assessment, data analysis, manuscript preparation, administrative and technical support.

Joshua Z. Goldenberg: Concept, screening, inclusion/exclusion, data extraction, quality assessment, data analysis, manuscript preparation, administrative and technical support. 
Claire Humphrey: Data extraction, quality assessment, manuscript preparation.

Regina El Dib: Screening, data interpretation, manuscript preparation.

Bradley C. Johnston: Concept, developed review protocol, search strategy, screening, inclusion/exclusion, data extraction, quality assessment, data analysis, manuscript preparation, administrative and technical support.

Previous versions of the review: Please refer to the 2007, 2011 and 2015 versions of the Cochrane review for previous contributions (Johnston 2007; Johnston 2011; Goldenberg 2015).

\section{DECLARATIONS OF INTEREST}

Qin Guo: None known.

Joshua Z Goldenberg: None known.

Claire Humphrey: None known.

Regina El Dib: None known.

Bradley C Johnston: None known.

\section{SOURCES OF SUPPORT}

\section{Internal sources}

- No sources of support supplied

\section{External sources}

- Hospital for Sick Kids Foundation, Toronto, Ontario, Canada.

\section{DIFFERENCES BETWEEN PROTOCOL AND REVIEW}

1. In our previous 2015 review, we abstracted data on mean stool frequency and mean stool consistency. Since there were very limited data available on these outcomes (i.e. only 4 studies reported stool frequency, none reported stool consistency independently) and given that this outcome overlaps with AAD (a more patient important outcome), we have removed these outcomes. In this update review, we have included microbiome characteristics as an outcome given the clinical communities interest in the impact of antibiotics and probiotics on the microbiome.

2. In our previous 2015 review, we assessed the effectiveness of probiotics for AAD prevention based on the definition of diarrhea using two subgroups: 1. strictness of definition, 2. definition of diarrhea. For 'strictness of diarrhea', we previously used two categories '> or $=$ to moderate' versus '< moderate'. For this update, we have revised the wording to 'moderate' versus 'mild' AAD.

3. In our previous 2015 review, we referred to diagnosis, inpatient versus outpatient, single versus multiple species and industry sponsorship as post hoc subgroup analyses as these were generated based on peer-review feedback. In this update review, we have considered each of these as a priori subgroups. We now have nine a priori subgroups in total.

4. Based on prospective observational data that provides the best estimate of the baseline risk of AAD in children, in this review we have added one new post-hoc subgroup on age $\leq 24$ months versus $>24$ months.

\section{N O T E S}

To assess risk of bias for blinding and to generate Figure 3, we collapsed both blinding domains (participants/personnel and outcome assessors). If both domains were low risk of bias, the risk of bias for blinding was low. If one domain was high and one low, we assumed risk of bias for blinding was high overall. If one domain was low and one unclear, we assumed risk of bias for blinding was low overall.

\section{INDEX TERMS}

\section{Medical Subject Headings (MeSH)}

Anti-Bacterial Agents [ ${ }^{\star}$ adverse effects] [therapeutic use]; Diarrhea [etiology] [ ${ }^{\star}$ prevention \& control]; Probiotics [*therapeutic use]; Treatment Outcome

\section{MeSH check words}

Adolescent; Child; Child, Preschool; Female; Humans; Infant; Infant, Newborn; Male 